


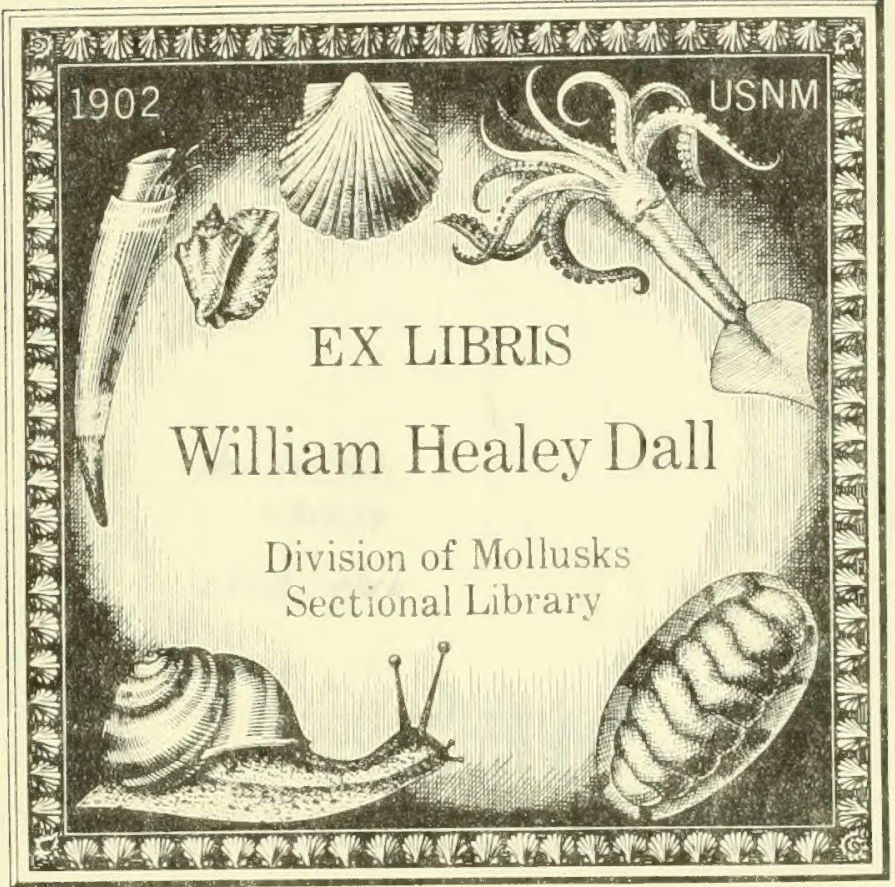

This book was bound through

the generosity of the

National Capital Shell Club 


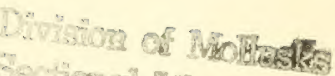
Sectionel Iithrony 

, 


\title{
CONCHOLOGIA SYSTEMATICA,
}

\section{or \\ COMPLETE SYSTEM OF CONCHOLOGY:}

IN WHICH

\section{THE LEPADES AND CONCHIFEROUS MOLLUSCA}

ARE DESCRIBED AND CLASSIFIED

ACCORDING TO THEIR NATURAL ORGANIZATION AND HABITS.

By LOVELL REEVE, F.Z.S., MEMBER OF THE CUVIERIAN SOCIETY OF PARIS, ETC.

IN TWO VOLUMES.

VOL. I.

o, quantum Natura varia est! componit, coagmentat, separat, iterum jungit, ludit quoque, ut fallere videatur; sed manet simplicissima, manet veridica natura :-post Biblia sacra, nullus mibi carior libro natura.

KLeIN, Tentamen Methodi Ostracologicu.

Pro exercitu gymnastico et palæstrico hoc habemus, Echinos, Lepades, Ostreas, Balanos captamus, Conchas.

Plavtus, Rudens.

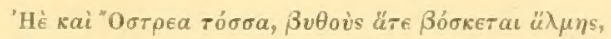

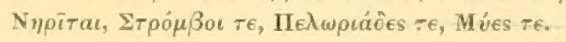

NiCANDER.

\author{
LONDON : \\ PUBLISHED AND SOLD BY
}

LONGMAN, BROWN, GREEN AND LONGMANS, PATERNOSTER-ROW:

J. B. BAILLIÈRE, PARIS :-ASHER AND CO., BERLIN :-WILEY AND PUTNAM, NEW YORK. 



\section{NOTICE}

AFTER CAREFUL EXAMINATION OF THE INNER MARGIN AND TYPE OF MATERIAL WE HAVE SEWN THIS VOLUME BY HAND SO IT CAN BE MORE EASILY OPENED AND READ.

\section{SIGISMUND RUCKER, ESQ., F.L.S., F.H.S., ETC.,}

A GENTLEMAN NOT LESS DESERVEDLY ESTEEMED

$$
\text { FOR }
$$

HIS GOOD HEART AND GENEROUS DISPOSITION,

THAN FOR

HIS ZEAL IN THE PURSUTT OF THE NATURAL SCIENCES,

\section{THESE VOLUMES}

ARE RESPECTFULLY DEDICATED

BY HIS OBEDIENT SERVANT,

THE AUTHOR. 



\section{A D D R ES S.}

OX the sth of July last I had the honour of laying before the Acarlemy of sciences at Paris, the outline of a classification which I propose to offer for the arrangement of the LEPADEs and Conchiferous Moluusca; and I now submit my "Conchologia Systematica" to the attention of naturalists, in the hope that it may, at least, contribute something to our imperfect knowledge of these remarkable animals.

It is not my intention to add to the controversy on the true definition of this science, nor to acknowledge any distinction between the study of Malacology and that of Conchology: I conceive the natural history of the animal to be inseparable from that of the shell, and have adopted the latter term as the original and most suitable.

My object in the foregoing arrangement has been to carry out as closely as possible the general views and intentions of that great conchologist LAMدRCK; his genera have been for the most part adopted, and only such alterations and additions have been marle in the nomenclature and relative distribution of these animals, as the progress of science has rendered necessary; in all cases, however, this has been done with caution.

It is pleasing to me to acknowledge that I have profited considerably by the labours of Cuvier. De Blainville, Deshayes, 
Owen, Gray, Broderip, Sowerby, \&c., and have been thus enabled to embody much new and important matter communicated from time to time by these authors, but hitherto comparatively lost in various scattered memoirs and monographs.

The whole of the descriptive characters of the several divisions have been carefully revised, and such as have seemed sufficiently appropriate are adopted; still, in this part of the work, the alterations are not inconsiderable.

The historical and scientific observations have been arranged with care, and are detailed in as concise a form as possible. The genera are furnished with so many examples of species, with their synonyms, as have been considered of interest, and each is accompanied with one or more accurate figures.

The illustrations have been kindly contributed by the Messrs. Sowerby ; two hundred plates are selected from the "Genera of Shells," fifty from the "Conchological Illustrations," and fifty are entirely new and original.

In conclusion, I beg to return my sincere thanks to the Rev. Mr. Stainforth, for the kind manner in which he has devoted a considerable portion of time to the perusal of $\mathrm{my}$ manuscript, and have now only to hope, that a long and exclusive study of the Lepades and Conchiferous Mollusca will be rewarded by the attention of naturalists.

73 York Road, London, 


\section{.}




\section{TA B U A M E T HODICA.}

SUBREGMA.

I.EPAI)ES .
CLASSES

ORDERS.

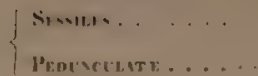

FAMILIES,

GEMERA.

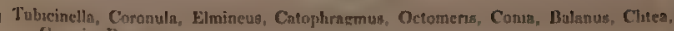
Creusia, Pyrgoate

Lithotnga, Pentelastris, Scalpelluna, Pollteipes, Cinaras, Otıon.
MOLLUSCA CONCHIFERA.
Brusectensa.....

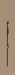

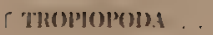

\section{(i.) ISTEROPOH)}

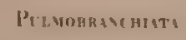

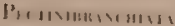

Crameинамсната

Cenveromathents

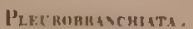

Xichanнастн14ta

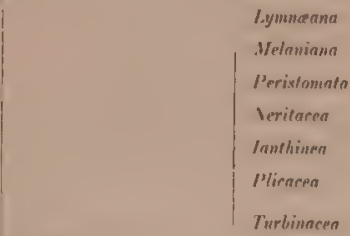

l'urasition

Canalifera

Ilizlit

Purpurifera

Fulumellato

Conpolutn

IVISONOW

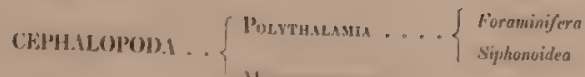

Aspergillum, Clavagella, Fiatulana, Gastmchena, Teredo

Xjlophaga, Pliolas

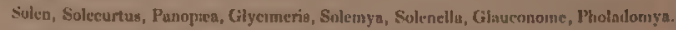
Mya, Anatina, Thracia, Corbula, Pandora, Anntunella, Myochama, Cleidatheras.

\{ Lutraria, Mfactra, Guathoton, Crassatella, Mesndesma, Unguline, Araphidestoa Cumingin.

sixienva. P'etricola

Simguinolaria, Psammotia, Galıommn, Tellinn, Corbis, Lucina, Donax, Capra. Cyeias, Cyzena, Galathara, Cyprina, Astarte, Venus, Cytheren, I'ullastro

Carduutn, Isocardia, Cardita, Cypricardaa

Cucullari, Arca, Pectunculus, Nucuta

Trieonia.

Lnio, Hyrua, Anodon, Iridina, Mycetopur

Eotheria, Chnma

Truducns, Hippopter

Lithodanus, Mocholo, Mytulus, Pınna

Crenatula, P'erna, Malleus, Vulsella, Ancula

l'edum, Lima, Pecten, ['licatuh, Spondy]us

Oatrea, Placuna, Placunanomia, Anomia

Lineula. Terebmtula

Thecidiutu, Crania, Orbicula.

Dentalium.

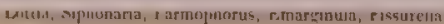

Crepudula, Calyptrara, Hipponyx, Pileopsí:

Velutinn, Sugaretus, Stomatia, Haliotrs

Siliquaria, Vermetus.

liulla

Peurobranclus, Umhrella

Aplysia, Dulabella

\section{Carinarıa}

l'armacella, Limax, Testacellus, Vir non

Ifelıx, Carocolla, Anostoma, Pupa, Clausilia, Bulinus, Partula, Achatina, Succunen

P'upina, Trunentelln, C'yelostoma, Nelicina

Auricula, Scarabus, Chilina

Manorbis, Lymnixa, Ancylus

Melania, Melanopsis

Valvata, Paludinn, Ampullaria

Navicella, Neritinu, Nerita, Neritopsis, Natuca

Janthuna

T'ornatellt, Pyramudellas

1 Ruswoa, Eulıma, Scalaria, Delphinula, Solarium, Pthorus, Rotella, Trorhus, Turh Mirearta, Lattorina, Phasianella. Turritell Siti hifes

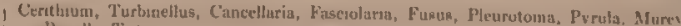
Ranella, Triton

Sitrutholarta, Rostellaria, Purroceria. Strombua

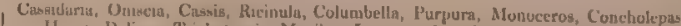
Harpa, Dolium, Triehotropis. Masilus, Leptoconschus, Huccinum. Nisma, Hlanari Eluurna, Ancillaria, ( )iva, Terehm

Volvarsa, Marcinella, Mitm, Volata, Melos, C'vmha

limito, Cypraxu, Uvula, Terebellum. Coms

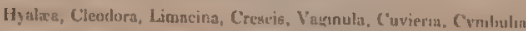

Usbiculna, Npiroloculına, Polystornella, Textularaa, Noducarn.

Spruin, Nautulus

Arronauta 


\section{HISTORY AND PROGRESS}

\section{OF

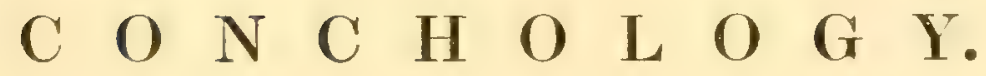

The science of Conchology comprehends the natural history and arrangement of the Lepades and Conchiferous Mollusca, which are soft inarticulated animals, inhabiting or producing testaceous shells, and the most highly organized of the Invertebrata, or animals without vertebræ.

$\mathrm{By}$ the term Conchology, we mean to impiy the history and classification of the shell, in connexion with the physiology of its animal. The word k'sy oc, from which it is derived, signifies equally a shell or a shell-

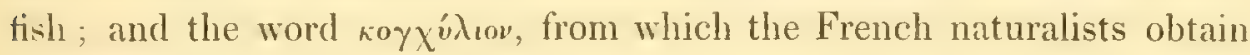
the term "Conchiliologie," has precisely the same signification-" le mot veut dire, non pas une coquille seulement, mais l'animal qui en est revetu," (De Blainville.)

Although Aristotle and Pliny have presented a systematic arrangement of these animals under the common title of Exsanguinea, or animals without blood, yet the first attempt towards a complete system of Conchology was made by Daniel Major, a Professor of Medicine in the University of Kiel, in the year 1675, when the study of this science began to assume a new form, and was followed with considerable zeal br several eminent naturalists. Lister, Rumphius, Gualter, Argenville, Klein and Adanson successively contributed to its advancement; and in 1750 a complete though simple arrangement was established by Linnæus in his 'Systema Naturæ,' illustrated in a voluminous work by VOL. I. 
Martini, continued by Chemnitz, and finally completed by Schubert and Wagner.

This system, however, although it embodied all that was at that time known of the nature and habits of the animal, was based almost entirely upon the relative characters of the shell; and as new forms began to appear, and more frequent opportunities occurred of investigating their anatomy, it was found wholly inefficient; it therefore became necessary to propose a new and more extended classification.

Bruguière, De Montford, Cuvier and Lamarck were all variously occupied in reorganizing the arrangement and division of these animals; and in 1819 a complete and improved system of Conchology was published by the last-naned author in his 'Histoire Naturelle des Animaux sans vertèbres, referring to the accurate figures already published in the 'Encyclopédie Méthodique.'

Since the time of Lamarck, considerable progress has been made in the knowledge of the animal inhabitant, and the science is now beginning to assume a more legitimate form. De Blainville in his 'Manuel de Malacologie,' Sowerby in his 'Genera of Shells,' Deshayes in the - Encyclopédic Méthodique,' Gray and other eminent living conchologrists, whose scattered memoirs and monographs have appeared from time to time, torether with the valuable labours of the American naturalists, Lea, Say, Conrad, \&c., as well as the important discoveries of those enterprising travellers King, Belcher, Fremble, Cuming, Quoy, and Gaimard, have all contributed more or less to its present advancement; though from the fact of the greater part of these animals having been found in deep water, or at the tops of almost inaccessible mountains, we are led to the conclusion that many species yet remain to be discovered, and that we are still very far from the attainment of a proper knowledge of them.

The Lepades and Conchiferous Mollusca are exceedingly variable in form, but are all characterized as being soft, fleshy, inarticulated animals, entirely destitute of bone or cartilaginous skeleton; they are enveloped in a large slimy tunic or mantle, and mostly furnished with certain organs, more or less perfectly developed, analogous to the head, foot and eye in 
the higher orders; also with certain glands for the secretion of a chalky, muculent matter, which is exuded during the growth of the animal, and becoming hardened and moulded on the body, forms a firm calcareous shell for protection or covering.

The various colours and markings produced in the formation of the shell are frequently of the most vivid and harmonions description, and the varieties of form are elegant and symmetrical; the outer surface is often covered with a strong epidermis, and the inner parts, and those enveloped by the mantle, are lined or coated with a clear polished enamel; the animal moreover has the property of restoring its shell in the erent of accident, until, from the commencement or nucleus of its birth, it has performed the determined operation of growth.

The system of reproduction in these animals is either oviparous or viviparous ; they are marine, fluviatile, or terrestrial, distributed throughout creation in greater or less abundance, but most prolific in the warm and tropical regions, where, as in all other branches of Natural History, the most beautiful forms and colours exist.

The Indian and Pacific Oceans, the great rivers of America, the hills and forests of Australia and the Philippine Islands, are all equally rich in the production of these wonderful animals. In the sea they are found in deep water, either living free, or attached to difterent marine substances; sometimes buried in the sand, or fixed to rocks, timber, seaweed, \&c.; and they are also found boring, imbedded in coral, wood, or stone. In rivers they float up and down with the tides, or adhere to different vegetable substances; and on the tops of hills and in forests they are found on the branches of trees, creeping anongst the roots of shrubs. or under the decayed and fallen leaves scattered on the earth.

The system we adopt for our classification is distinctly based upon the principles established by LAMAreK, the alterations and additions which the progress of science has rendered necessary so entirely according with the general riews of that great maturalist. It is true, that the arrangement introduced by Gray contains many excellent genera, and is moreover formed upon a skilful linowledge of the animal; but we are of opinion that the principle of subdivision is carried too far. 'The points upon 
which he founds many of his generic distinctions are so slight, that minute variations are exalted to the rank of distinct characters; hence a multiplicity of genera are created, which tend rather to confuse than to simplify a study, in which the endless modifications of nature should be arranged in a clear and concise form, in accordance with her perfect harmony of contrivance.

S Y NOPSIS GE N E R M.

\section{LEPADES.}

Order I. Sessiles.

Tubicinella. Conia.

Coronula. Balanus.

Elmineus. Clitea.

Catophragmus. Creusia.

Octomeris. Pyrgoma,

Order II. Pedunculat...

Lithotrya. Pollicipes.

Pentelasmis. Cinaras.

Scalpellum. Otion.

\section{MOLLUSCA CONCHIFERA.}

\section{Class 1. TROPIOPODA.}

Order I. Bimusculosa.

Family 1. Tubicola.

Aspergillum. Gastrochæna.

Clavagella. Teredo.

Fistulana. 
Family 2. Pholadaria.

Xylophaga. Pholas.

Family 3. Solenacea.

Solen.

Solemya.

Solecurtus. Solenella.

Panopæa. Glauconome.

Glycimeris. Pholadomya.

Family 4. Myaria.

Mya.

Pandora.

Anatina.

Anatinella.

'Thracia.

Myochama.

Corbula.

Cleidothærus.

Family 5. Mactracea.

Lutraria.

Mesodesma.

Mactra.

Ungulina.

Gnathodon.

Amphidesma.

Crassatella.

Cumingia.

Family 6. Lithophaga.

Saxicava.

Petricola.

Family 7. Nymphacea.

Sanguinolaria. Corbis.

Psammobia. Lucina.

Galeomma. Donax.

Tellina. Capsa.

Family 8. Conchacea.

Cyclas.

Astarte.

Cyrena.

Venus.

Galathæa.

Cytherea.

Cyprina.

Pullastra. 
Family 9. Cardiacea.

Cardium.

Cardita.

Isocardia.

Cypricardia.

Family 10. Arcacea.

Cucullæa.

Pectunculus.

Arca.

Nucula.

Family 11. Trigonacea.

Trigonia.

Family 12. Naiades.

Unio.

Iridina.

Hyria.

Mycetopus.

Anodon.

Family 13. Chamacea.

Etheria.

Chama.

Order II. UNIsusculosA.

Family 1. Tridacnacea.

Tridacna.

Hippopus.

Family 2. Mytilacea.

Lithodomus. Mytilus.

Modiola. Pinna.

Family 3. Aviculacea.

Crenatula.

Vulsella.

Perna.

Avicula.

Malleus.

Family 4. Pectinacea.

Pedum.

Plicatula.

Lima.

Spondylus.

Pecten. 
SYNOPSIS GENERUM.

Family 5. Ostracea.

Ostrea.

Placunanomia.

Placuna.

Anomia.

Class II. BRACHIOPODA.

Family 1. Tendinosa.

Lingula. Terebratula.

Family 2. Adhcerentia.

Thecidium. Orbicula.

Crania.

Class III. Gasteropoda.

Order 1. Cirrobranchiata.

Dentalium.

Order 1I. Cyclobranchiata.

Chiton. Patella.

Chitonellus.

Order III. Cerviconranchiata.

Family 1. Fissuracea.

Lottia. Emarginula.

Siphonaria. Fissurella.

Parmophorus.

Family 2, Capulacea.

Crepidula.

Hipponyx.

Calyptræa. Pileopsis. 
Family 3. Macrostomata.

Velutina.

Stomatia.

Sigaretus.

Haliotis.

Family 4. Tubispiracea.

Siliquaria.

Vermetus.

Order IV. Pleunobranchiata.

Family 1. Bullacea.

Bulla.

Family 2. Semiphyllidiana.

Pleurobranchus. Umbrella.

Family 3. Aplysiana.

Aplysia.

Dolabella.

Order $\mathrm{V}$. Nucleobranchiata.

Carinaria.

Order VI. Pulmobranchiata.

Family 1. Limacinea.

Parmacella.

Testacellus.

Limax.

Vitrina.

Family 2. Colimacea.

Helix.

Bulimus.

Carocolla.

Partula.

Anostoma.

Achatina.

Pupa.

Succinea.

Clausilia. 
SYNOPSIS GENERUM.

Family 3. Cyclostomacea.

Pupina. Cyclostoma.

Truncatella. Helicina.

Family 4. Auriculacea.

Auricula. Chilina.

Scarabus.

Family 5. Lymnceana.

Planorbis. Ancylus.

Lymnxa.

Order VII. Pectinibranchiata.

Family 1. Melaniana.

Melania. Melanopsis.

Family 2. Peristomata.

Valvata. Ampullaria.

Paludina.

Family 3. Neritacea.

Navicella.

Neritopsis.

Neritina. Natica.

Nerita.

Family 4. Ianthinea.

Ianthina.

Family 5, Plicacea.

Tornatella. Pyramidella.

Family 6. Turbinacea.

Rissoa.

Delphinula.

Eulima.

Solarium.

Scalaria. Phorus.

VOL. I. 
Rotella.

Littorina.

Trochus. Phasianella.

Turbo. Turritella.

Margarita.

Family 7. Parasitica.

Stylifer.

Family 8. Canalifera.

Cerithium.

Pleurotoma.

'Turbinellus.

Pyrula.

Cancellaria.

Murex.

Fasciolaria.

Ranella.

Fusus.

Triton.

Family 9. Alata.

Struthiolaria.

Pterocera.

Rostellaria.

Strombus.

Family 10. Purpurifera.

Cassidaria.

Trichotropis.

Oniscia.

Magilus.

Cassis.

Leptoconchus.

Ricinula.

Buccinum.

Columbella.

Nassa.

Purpura.

Planaxis.

Monoceros.

Eburna.

Concholepas.

Ancillaria.

Harpa.

Oliva.

Dolium.

Terebra.

Family 11. Columellata.

Volvaria.

Voluta.

Marginella.

Melo.

Mitra.

Cymba. 
Family 12. Convolute.

Erato. Terebellum.

Cypraea. Conus.

Ovula.

Class IV. PTEROPODA.

Hyalrea. Vaginula.

Cleodora. Cuvieria.

Limacina. Cymbulia.

Creseis.

Class V. CEPHALOPODA.

Order I. Polythalamia.

Family 1. Foraminifcre.

Orbiculina. Textularia.

Spiroloculina. Nodosaria.

Polystomella.

Family 2. Siphonoidea.

Spirula. Nautilus.

Order II. Monothalami.

Argonauta.

c 2 


\section{DISTRIBUTIO METHODICA.}

\section{LEPADES.}

Animalia mollia, affixa; capite oculisque nullis ; corpore subresupinato, inarticulato, in tegmine amplo, quasi in pallio involuto, tentaculis numerosis cirratis, multiarticulatis, per paria dispositis, desuper instructo, per orificium superius exeuntibus; ore subinfero, non prominulo, maxillis lateralibus dentatis linguâque rudimentariâ munito. Systema nervosa ganglionorum seriem symmetricem format. Circulatio corde indistincto vasculisque confecta ; respiratio branchiis pectinatis, duabus aut pluribus, sæpissimè absconditis, ad basem tentaculorum appositis.

Testa rel sessilis, vel pedunculo flexili, tendineo, elevata, partibus pluribus composita, modò mobilibus, distantibus, modò conferruminatis, pallio aut tegmine intùs vestitis.

Few animals throughout the system of nature present a more singular anomaly in their organization than the Lepades; they may be said to partake of the characters of three distinct divisions of Invertebrata, the Crustacen, the Annelides and the Mollusca, but are not immediately referable to either. Like the Crustacea they are provided with numerous articulated tentacular cirri and other organs, but the body is not articulated, and is moreover entirely destitute of head or eyes : as in the Amnelides the body offers an indication of transverse wrinkles, and as in the Mollusca it is enveloped in a tunic or mantle, which produces certain pieces of solid calcareous shell, differing entirely in composition and structure from that of the Crustacea.

In considering the relative value of this anomalous union of characters 
in the organization of the Lepades, we have felt no little embarrassment in determining the situation they should occupy in the system. Cuvier arranged them as an inferior class of Mollusca; Lamarck distinguished them as a separate division, equal in rank to those already referred to; De Blainville divides the Mollusca into Articulata and Inarticulatir, referring the Lepades to the former; and Gray unites them with the Entomostraca, an order of Crustacea.

The last of these arrangements is certainly deserving of attention, because, upon reference to the descriptive characters of the Lepades, it may be noted, that the most important organs are those by which they are more nearly allied to the Crustacea; and that as their anatomy has become more accurately demonstrated, so their affinity with those animals has been the more fully established; still, however, we cannot but think, that the production of certain solid testaceous pieces of shell, differing so entirely both in structure and composition from the shell of the Crustacea, fully entitles the Lepades to form a separate and distinct division, in accordance with the original intention of Lamarck.

The Lepades may be described as being soft inarticulated animals, entirely destitute of head or eyes; the body, looking as if reversed, is not articulated, but exhibits some indication of being disposed in transverse rings or wrinkles; it is enveloped in a large integument or mantle, and furnished towards the upper part with numerous articulated tentacular cirri, arranged in pairs, and passing through an opening at the top; the mouth is subinferior, not prominent, and furnished with lateral dentated jaws, as also with a small rudimentary tongue. The nervous system forms a symmetrical series of ganglions. Circulation is performed by an indistinct heart communicating with numerous small vessels; and respiration by two or more pectinate branchire situated at the base of the tentacula, but often concealed.

All the Lepades are oviparous, and eject their eggs through the orifice at the upper part of the mantle. When the egg is broken, the animal comes forth perfectly developed; it soon attaches itself to the nearest body, and then begins to secrete certain portions of shelly matter. 
It has been supposed by some naturalists, that the Lepas, when young, is a free swimming animal, having considerable power of locomotion; that it is furnished with a kind of bivalve shell, as also with distinct pedunculated eyes, and that atter a certain period it fixes itself to some marine body.

It is asserted, that upon thus becoming attached, the animal passes through a series of metamorphoses, throws off the bivalve shell, and, having $n$ further occasion for an organ of vision, covers the eyes with calcareous matter. We have not, however, succeeded in testing this hypothesis, and feel much rather inclined to follow the observations of Gray, published in the 'Proceedings of the Zoological Society.'

Although Bruguière separated the pedunculated from the sessile Lepades by dividing them into two genera, Anatifa and Balamus, Dr. Leach may be considered as the first who succeeded in establishing a clear and natural arrangement of these singular animals. 'They were also similarly divided by him into Cumpylosomate and Acampylosomata, the Pedunculate and sessilia of Lamarck; but by assigning to these divisions the rank of orders, he was enabled to introduce several distinct and characteristic genera, which have been for the most part adopted. $\mathrm{He}$ also made several smaller subdivisions in manuscript in the British Museum, which have been cmbodied by Gray in a skilful monograph on these animals in the 'Annals of Philosophy'; we do not, however, at present see the necessity of so extended a classification.

It may be as well to state that we have abandoned the term Cirripedes for the original title of Lepades, because we conceive the former to be inappropriate. It is obvious that the cirri cannot be considered as feet or legs; they are not organs of locomotion, and certainly not analogous to the locomotive organs which characterize the primary distribution of the Mollusca.

In accordance with the arrangement above noted, we divide the Lepades into two orders, as follows:

Sessiles.

Pedunculate. 


\section{Order I. LEPADES SESSILES.}

Corpus, pedunculo nullo, in testâ ad basem affixâ inclusum.

The Sessile Lepades are contained in a circular coniform shell, consisting of several solid calcareous pieces united together at the sides, and fixed immediately at the base, which is either testaceous or membranaceous, upon some marine substance; and they have a moveable operculum at the top inserted within the aperture, composed of two or more testaceous pieces, separable at the will of the animal for the passage of the tentacular cirri. We divide them into ten genera as follows:

$\begin{array}{ll}\text { Tubicinella. } & \text { Conia. } \\ \text { Coronula. } & \text { Balanus. } \\ \text { Elmineus. } & \text { Clitea. } \\ \text { Catophragus. } & \text { Creusia. } \\ \text { Octomeris. } & \text { Pyrgoma. }\end{array}$

TUBICINELLA, Lamarck.

Testa cylindraceo-fubulosa, subrecta, valvis sex longitudinaliter ferruminatis composita, extis longitudinaliter striata, costis transversis annulatim cincta, utrinque truncata ; basi membranâ clausa. Operculum quadrivalve, valvulis apice attenuatis, rotundatis.

The Tubicinella has a cylindrical tubular shell, nearly straight, truncated at both ends, and slightly attenuated torvards the base, which is closed by a thin membrane; it is composed of six longitudinal valves, striated on the outside, and encircled with an irregular number of transverse ribs, supposed to indicate different periods of growth, each in its turn having formed the margin of the aperture. The valves of the operculum are trapezoidal and obtuse, inserted in the orbicular aperture 
at the top. This singular Lepas is found imbedded in the skin and fat of the South Sea whale, which it penetrates in clusters.

\section{Example.}

Pl. I. Fig. 1 to 3.

Tubicinelia balenarum, Lamarck, Ann. du Mus., vol. i. p. 461. pl. 30. f. $]$.

Lepas tracheaformis, Linnæus.

Coronula tubicinella, De Blainville.

CORONULA, Lamarck.

Testa suborbicularis, obtuso vel compresso-conoidea, valvis sex inæqualibus lateraliter ferruminatis composita ; extremitate inferiori truncatâ, superiori operculo quadrivalvi membranâque clausî, valvis operculi obtusis, parietibus crassissimis intus plerumque cellulis radiantibus excavatis.

The shell of Coronula differs from that of Tubicinella in being of a more compressed form, never thickened at the margin, and consequently not encircled with transverse ribs. The substance of the longitudinal valves is internally divided into a number of radiating cells, or into irregular distorted ramifications. Some naturalists have formed distinct genera of these varieties; for instance, Dr. Leach his Chelonobia, and Kklein his Polylopos and Astrolepas; we must consider them, however. but as species, adhering to the original arrangement of Lamarck.

\section{Examples.}

PI. II. Fig. 1.

Coronula diadema, Lamarck, Anim. sans vert., vol. v. p. 387.

Lepas diadema, Linnæus.

Polylepas diadema, Gray.

Polylopos balænaris, Klein. 
TUBICINELLLA.

Plate I.
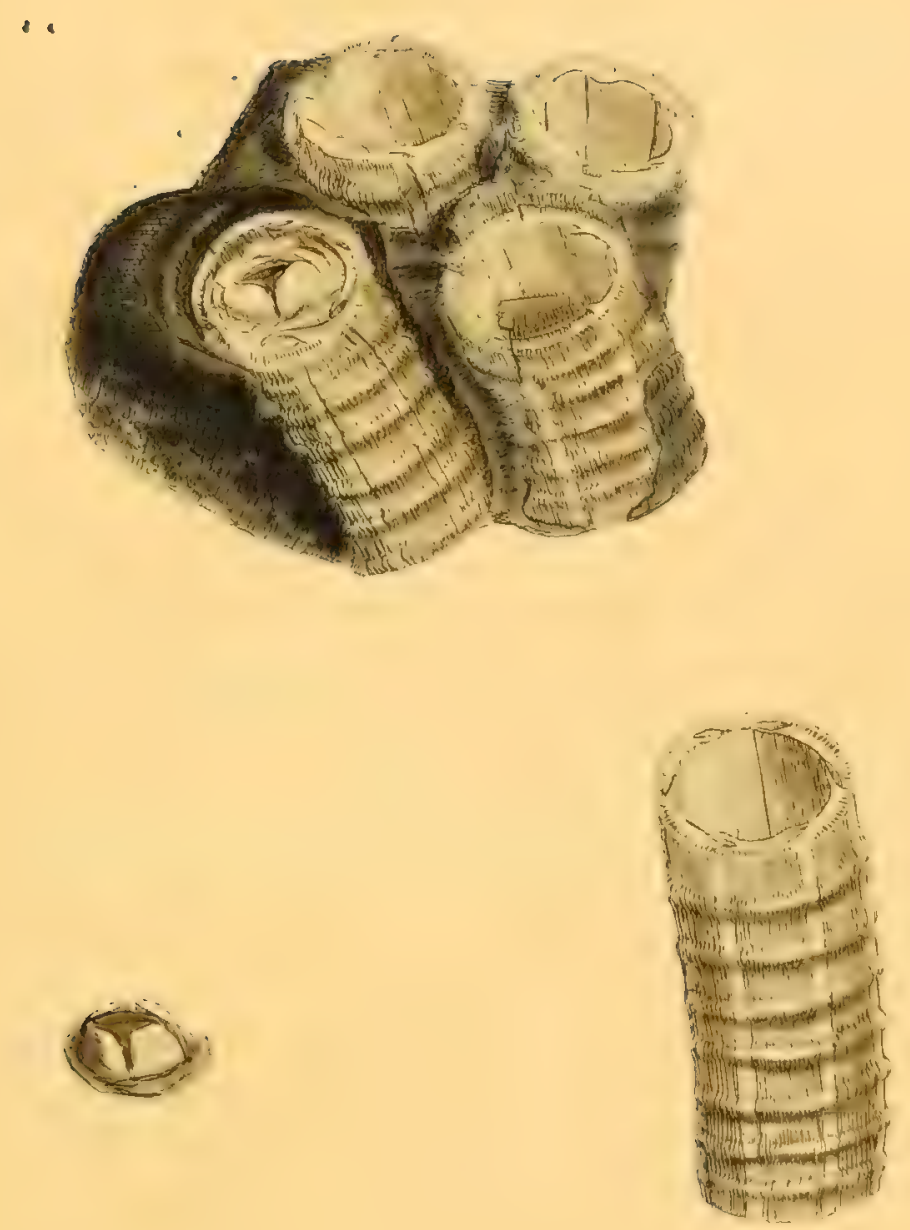

Tubicinella balsenanom. 



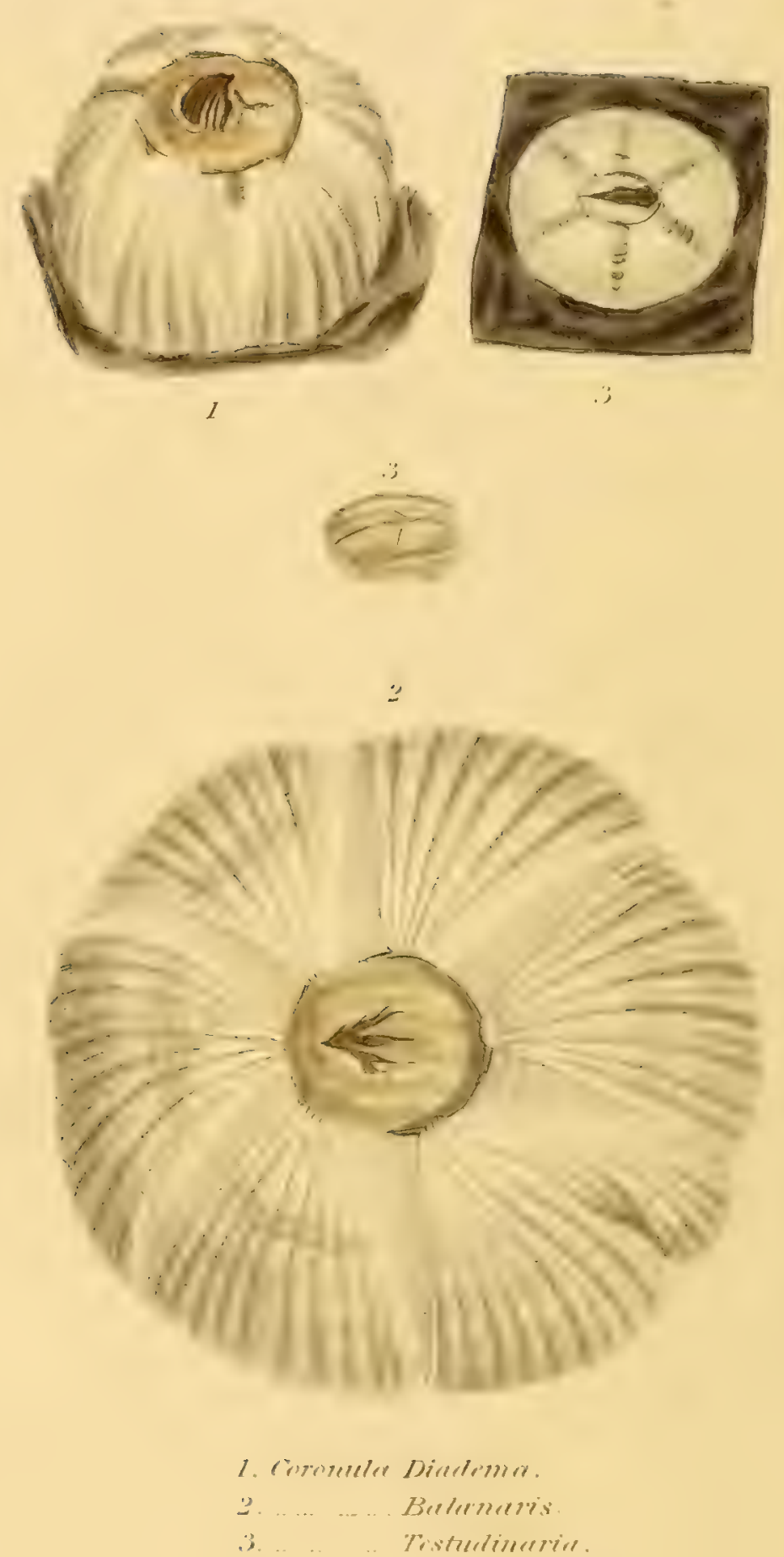


\section{,}


ELMINEUS.

Plate III.
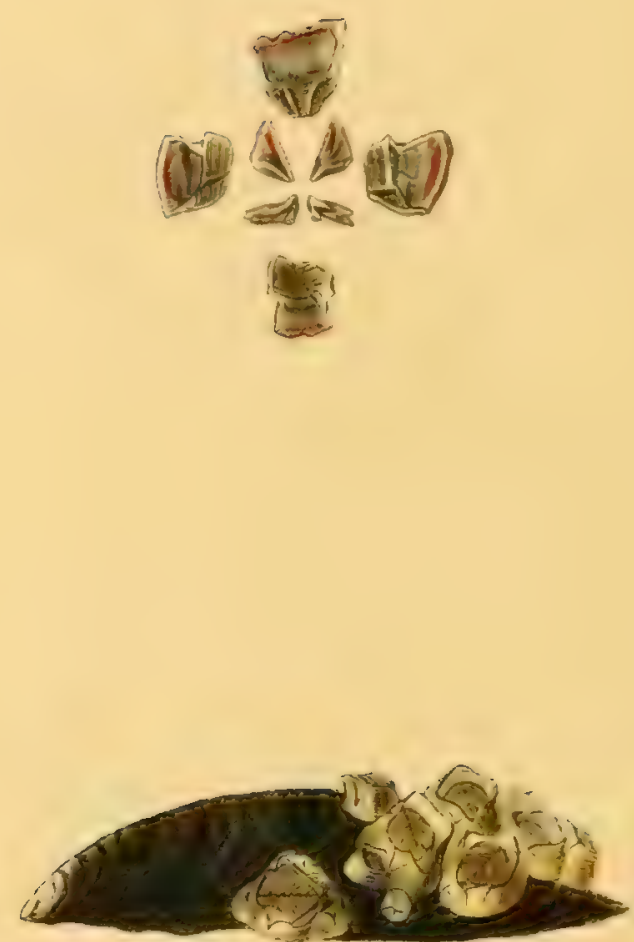
Pl. II. Fig. 2.

Coronula balenaris, Lamarck, Ann. du Mus,, vol. i. p. 468. pl. 30. f. ¿- to 4 .

Lepas balcenaris, Linnæus.

Polylepas vulgaris, Gray.

Pl. II. Fig. 3.

Coronula testudinaria, Lamarck, Anim. sans vert., vol. v. p. 387.

Lepas testudinarius, Linnæus.

Astrolepas testudinarius, Klein.

Chelonobia vulgaris, Leach.

ELMINEUS, Leach.

Testa subconica, valvis quatuor solidis inæequalibus lateraliter ferruminatis composita; aperturâ apicali magnâ, basi testaceâ nullâ; operculo valvis quatuor composito, pari antico subhorizontali.

The genus Elmineus, proposed by Dr. Leach, differs materially in its characters from the other Sessile Lepades; its shell is composed of four small, solid, unequal pieces, forming a very wide aperture at the top, but without a testaceous base. The operculum is large, corresponding with the size of the aperture, and consists of four pieces.

Example.

Pl. III. Fig. 1 and 2.

Elmineus Leachir, King, Zool. Journ., vol. v. p. 334.

CATOPHRAGMUS, Sowerby.

Testa subconica, apice pervio, valvis octo inæequalibus lateraliter adjunctis composita; valvis porrò plurimis per series externas circulares VOL. I. 
gradatim minores confertim co-ordinatis. Operculum bipartitum, valvis quatuor anticis majoribus compositum.

Not having had the opportunity of examining this rare and peculiar Lepas, we give verbatim the description of Sowerby, by whom it was introduced. "Like Octomeris, the shelly cone inmediately surrounding the animal consists of eight pieces, and its operculum is also composed of four; here, howerer, the resemblance ceases. The peculiarity of the present genus consists in a number of narrow perpendicular valves arranged around the above-mentioned shelly cone, and in rows like pales, the first row of which consists of eight pieces, placed so as exactly to cover the sutures of the cone immediately surrounding the animal; around this, are then placed several sets of more and more numerous pieces, gradually decreasing in size, so that the outer row, which is most numerous, consists also of the smallest pieces, the additional rows seeming to be produced as the animal increases in age."

Example.

PI. IV. Fig. 1 to 6.

Catophraguus imbricatus, Sowerby, Genera of Shells, No. 28.

\section{OCTOMERIS, Sowerby.}

T'esta subconica, valvis octo inxqualibus lateraliter conferruminatis composita; apice pervio, operculo valvis quatuor composito, anticis majoribus.

This is another peculiar variety of Lepas introduced by Sowerby, whose shcll, as its name implies, is composed of eight pieces, closed together at the sides, and distinguished by their internal sutures and foliaceous structure. In this character it differs essentially from the shell of Balanus, as also in having no testaceous base. The operculum is composed of four pieces, of which the anterior pair are the larger. 
CATOPHIRAGMUS.

Plate IV.
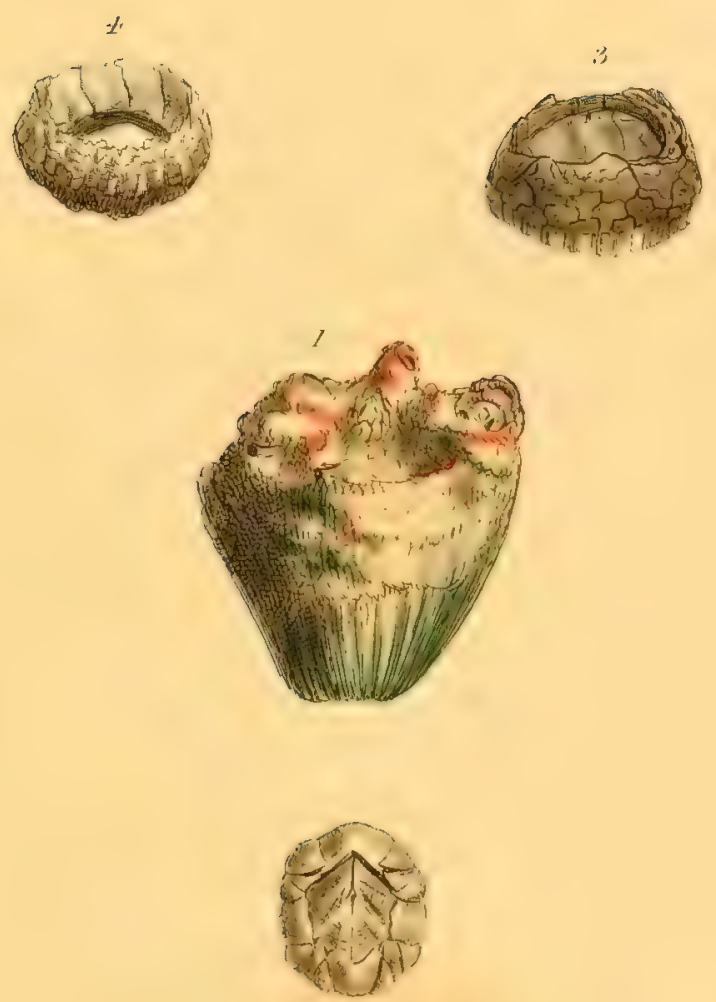

?
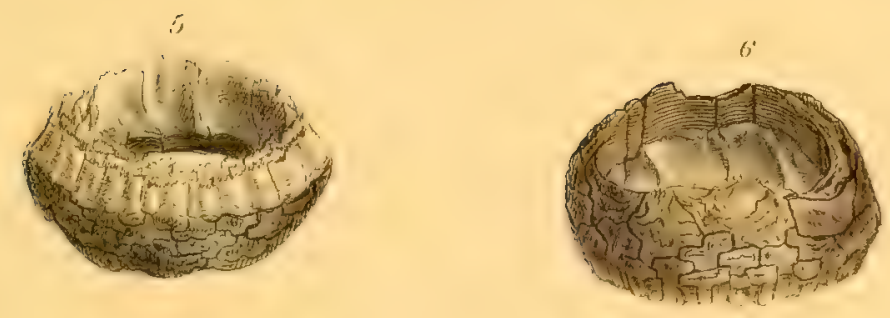

Cinlophleregunes imlnicatus: 
OCTOMERIS.

Plate $\mathrm{V}$.

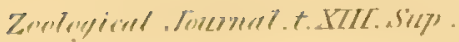
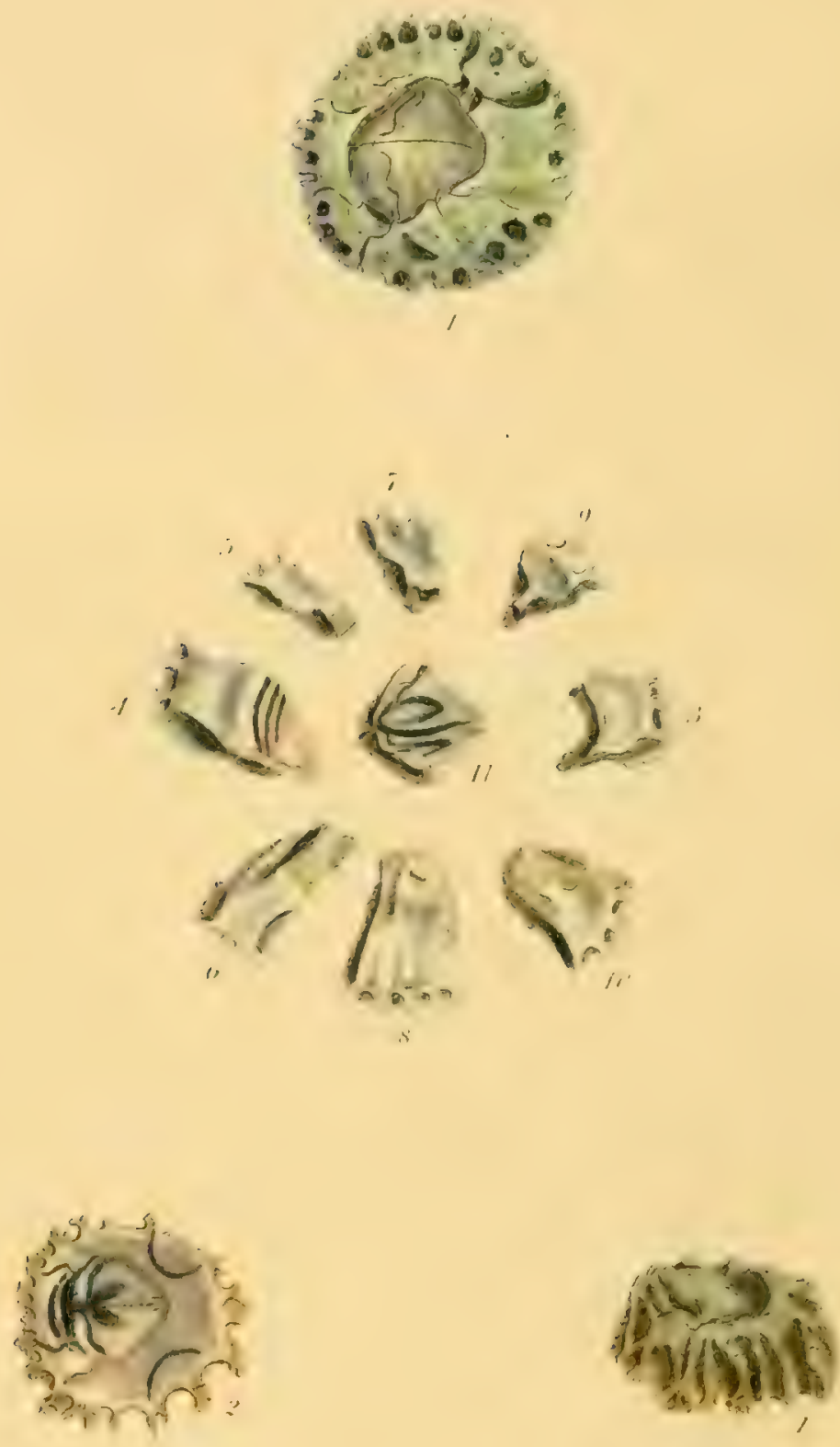

l'remeneris amemleser. 
. 
CONIA.

Plate VI.
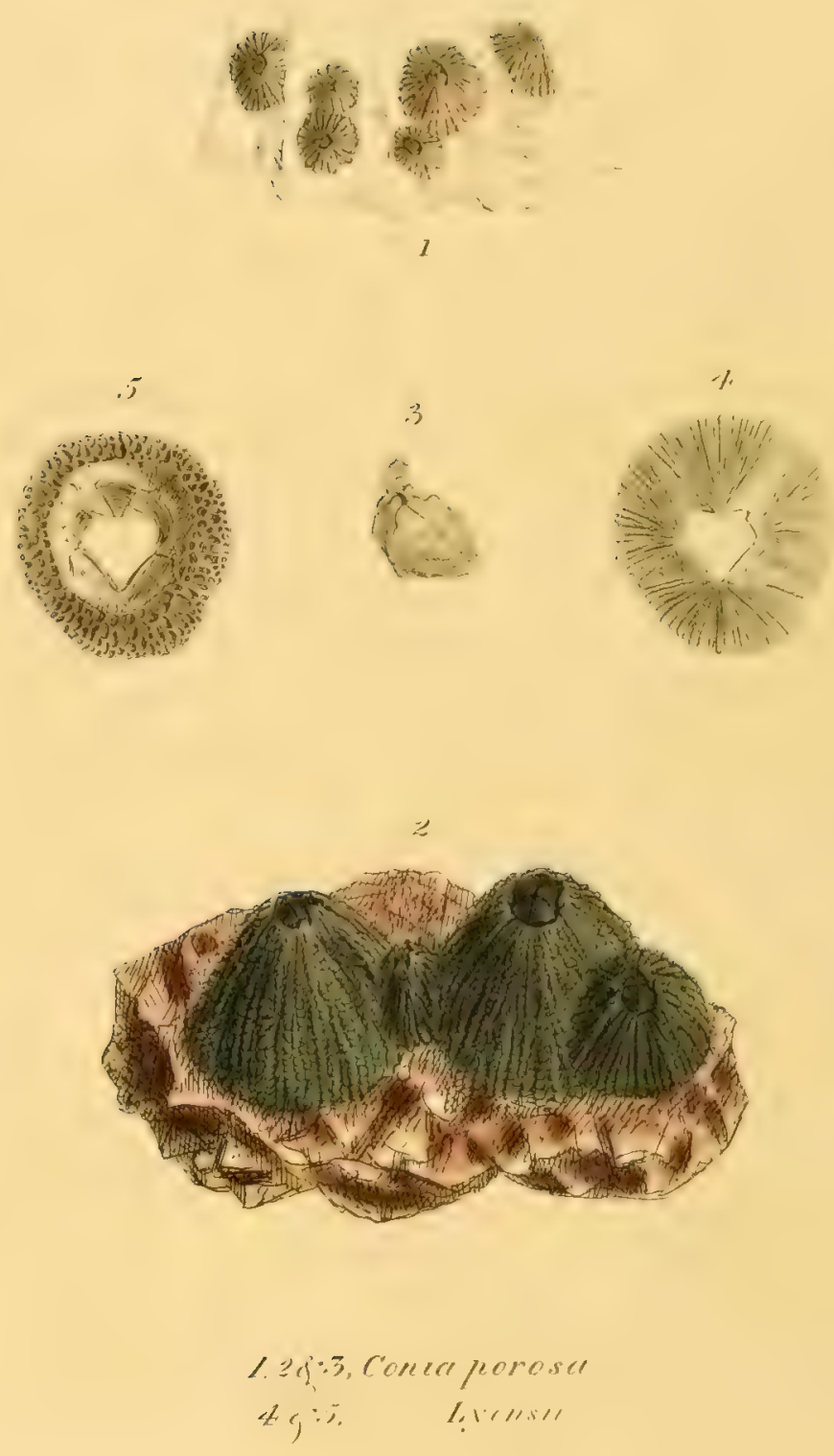
ORDER I. SESSILES.

Example.

Pl. V. Fig. 1 to 11 .

Octomeris angulosa, Sowerby, Zool. Journ., vol. ii. p. 244; Supp., pl. 12 .

Octomeris Stuchburii, Gray.

\section{CONIA, Ranzani.}

Testa conica, valvis quatuor porosis inæequalibus lateraliter ferruminatis composita; apice pervio, basi valvâ testaceâ clausâ. Operculum valvis quatuor compositum, pari postico prominulo.

The species which have been associated under the title of Conia were separated from the Balani by Ranzani, in which arrangement he was followed by Dr. Leach in the 'Supplement to the Encyclopedia Britannica.' Their shell is composed of four pieces only, so closely cemented together, that the divisions are scarcely discernible; and they are characterized by being more or less perforated with numerous cellular pores. The operculum is the same as in the shell of Balamus, and, as in that genus, the base is testaceous, flat and irregular, according to its accidental position of growth.

Examples.

Pl. VI. Fig. 1, 2, 3.

Conia porosa, Leach, Enc. Brit. Supp.

Lepas porosus, Linnæus.

Balanus stalactiferus, Lamarck.

Pl. VI. Fig. 4 and 5.

Conia Lyonsin, Leach, MSS. Brit. Mus.

Lepas Lyonsii, Wood. 


\section{BALANUS, Bruguière.}

Testa conica vel elongato-conica, valvis sex inæqualibus lateraliter ferruminatis composita; apice pervio, basi vel planulatâ vel concavâ lamellâ testaceâ clausâ. Operculum internum, valvis quatuor mobilibus compositum.

The genus Balanus includes by far the most numerous of the Sessile Lepades; their shells are exceedingly variable in form, growing irregularly to any kind of substance they come in contact with, and from which their animals have not the power of displacing them. For this reason we readily adopt the arrangement of Sowerby and De Blainville, in reuniting to this genus the Acustc of Dr. Leach; they were separated on account of the base of the shell assuming a concave or cup-shaped form; but this merely arises from the peculiarity of their place of habitation, which is generally in soft sponges.

The shell of Balanus may be described as being conical or elongately conical, composed of six unequal pieces or valves, closed at the sides upon a firm testaceous base, which is either flat or concave, according to its place of habitation. The shell is open at the top, with an operculum inserted, consisting of four moveable valves.

The Balani are abundantly prolific, growing in large irregular clusters one upon the other.

$$
\text { Examples. }
$$

Pl. VII. Fig. 1.

Balanus tulipa, Lamarck, Anim. sans vert., new edit., vol, v. p. 658. Balanus tintinnabulum, var. Sowerby.

Lepas tulipa, Poli.

$$
\text { PI. VII. Fig. } 2 .
$$

Balanus Spinosus, Lamarck, Anim. sans vert., new edit,, vol. v. p. 661. Enc. Méth., pl. 164. f. 10.

Lepas spinosa, Gmelin. 
BALANUS.

Plate VII.

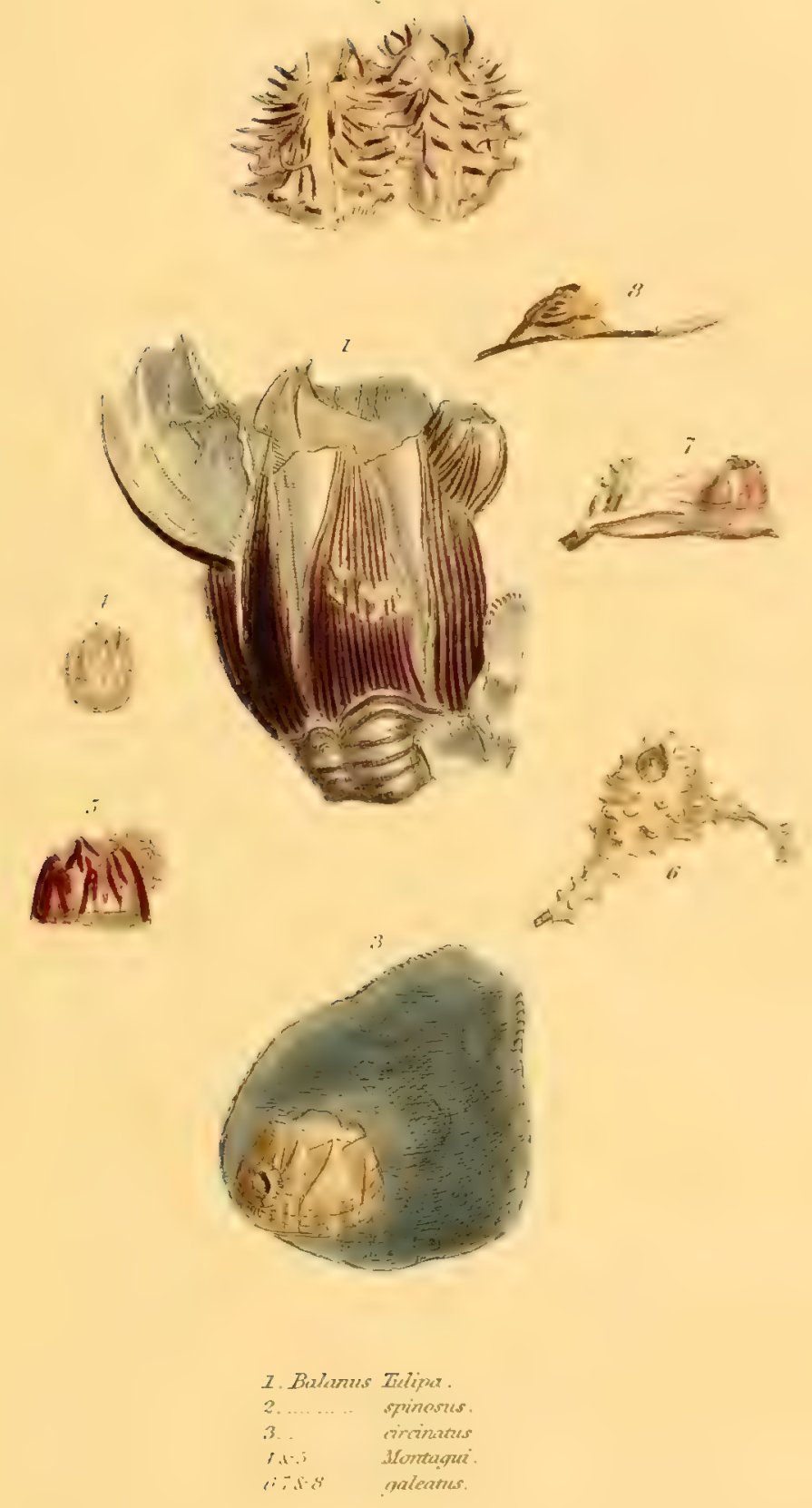



CLITEA.

Plate V1II.

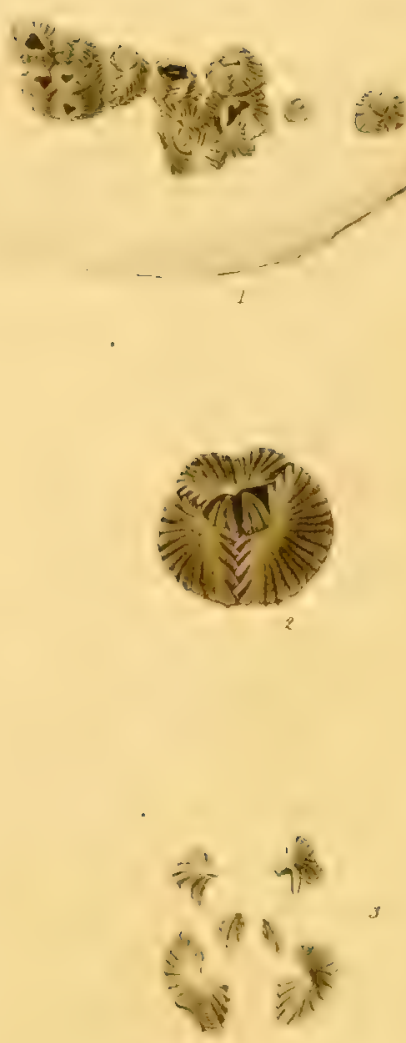


Pl. VII. Fig. 3. (fossil).

Baianus circinatus, Defrance. Sowerby, Genera of Shells, No. 12. Lamarck, Anim. sans vert., new edit, vol. v. p. 666.

Pl. VII. Fig. 4 and 5.

Balanus Montagui, Sowerby, Genera of Shells, No. 12.

De Blainville, Manuel de Malacologie, p. 597. pl. 85. f. 3. Acasta Montagui, Leach.

\section{Pl. VII. Fig. 6 to 8 .}

Balanus galeatus, Lamarck, Anim. sans vert, new edit., vol. v. p. 664.

Conoplea elongata, Say.

CLITEA, Leach.

Testa compresso-conoidea, valvis quatuor iniequalibus, duabus majorbus, duabus minoribus, lateraliter intertextis composita; aperturâ trapeziformi, operculo bipartito clausâ. Valva operculi, altera irregulariter tetragona, altera subtrigona.

Dr. Leach, whose minute investigation of the Lepades is entitled to the greatest attention, was the first to propose this genus; it is the Lepas vermea of the old authors, and was erroneously placed by Lamarck with the Creusia. Its shell is small, composed of four unequal pieces, interdented together at the sides. The operculum is bipartite, one part yuadrangular, the other nearly triangular.

\section{Examples.}

PI. VIII. Fig. I and 3.

Clitea levigata, Sowerby, Genera of Shells, No. 33. 


\section{Pl. VIII. Fig. 2.}

Clitea verruca, Sowerby, Genera of Shells, No. 33.

Lepas verruca, Gmelin.

Creusia verruca, Lamarck.

Verruca Stromii, Gray.

\section{CREUSIA, Leach.}

Testa convexo-conica, orbiculata, valvis quatuor inæqualibus lateraliter ferruminatis composita; apice pervio, basi testaceâ, modò caliciformi, modò tubulari, madreporis infixâ, clausâ. Operculum internum, bipartitum, valvis quatuor compositum.

The genus Creusia was also instituted by Dr. Leach, and, like the folInwing, is always found deeply imbedded in the surface of different kinds of' ('orals and Madrepores, this being its peculiar mode of habitation. Thr shell is of a conical patelliform shape, consisting of four pieces ('losed upon a grooved testaceous base, penetrating the Coral in the shave of at cup or tube. The operculum is bipartite, composed of four valves.

Example.

PI. IX. Fig. 1 to 6.

Creusia gregaria, Sowerby, Genera of Shells, No. 18.

PYRGOMA, Savigny.

Testa compresso-conica, indivisa, supernè convexa; apice pervio, basi testaceît, modò caliciformi, modò tubulari, madreporis infixâ, clausâ; aperturâ parrì, subovali. Operculum internum, bipartitum, valvis quatuor compositum.

The grenus Pyrgoma was proposed by Savigny, but divided into four 
CREUSIA

Plate IX.
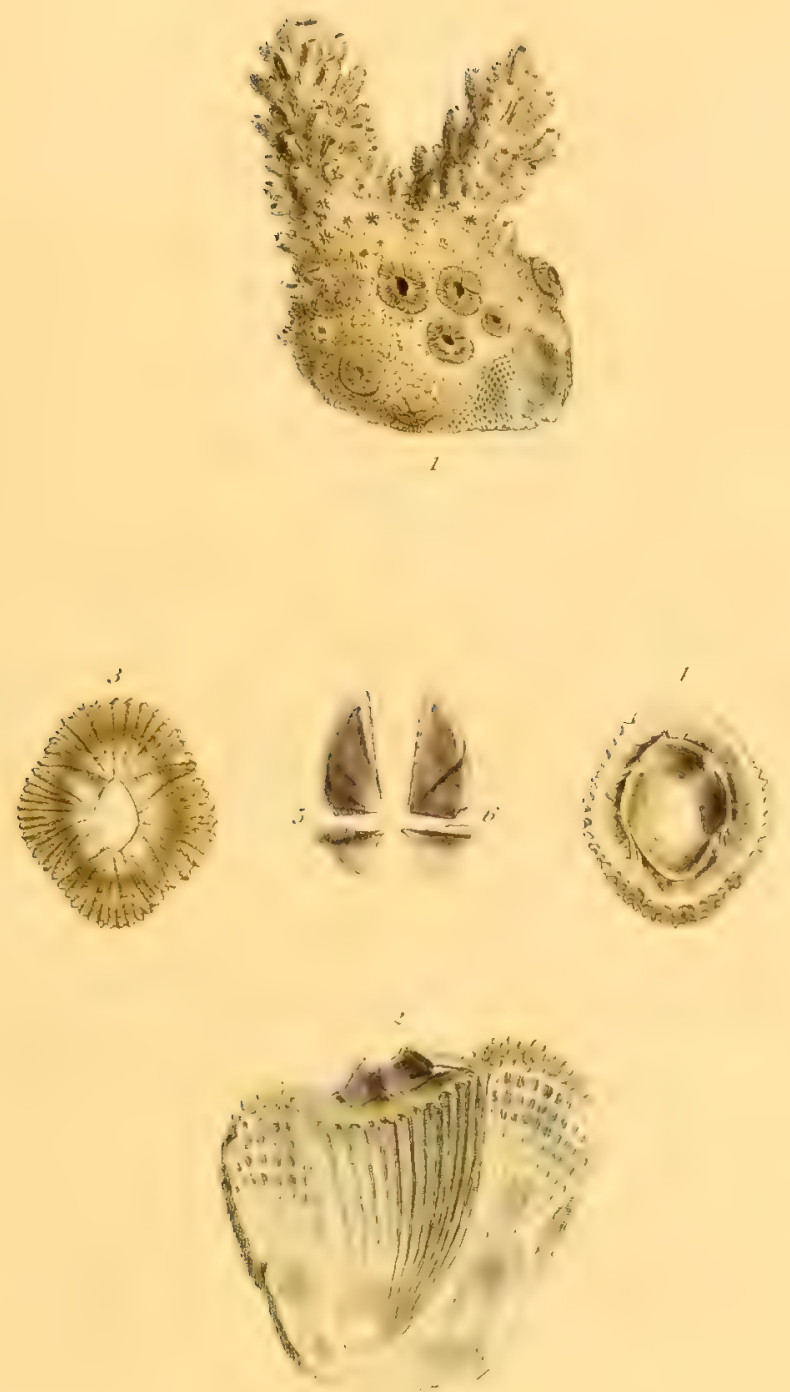

Cinzusue groguma. 


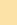


PYRGOMA.

Plate X.
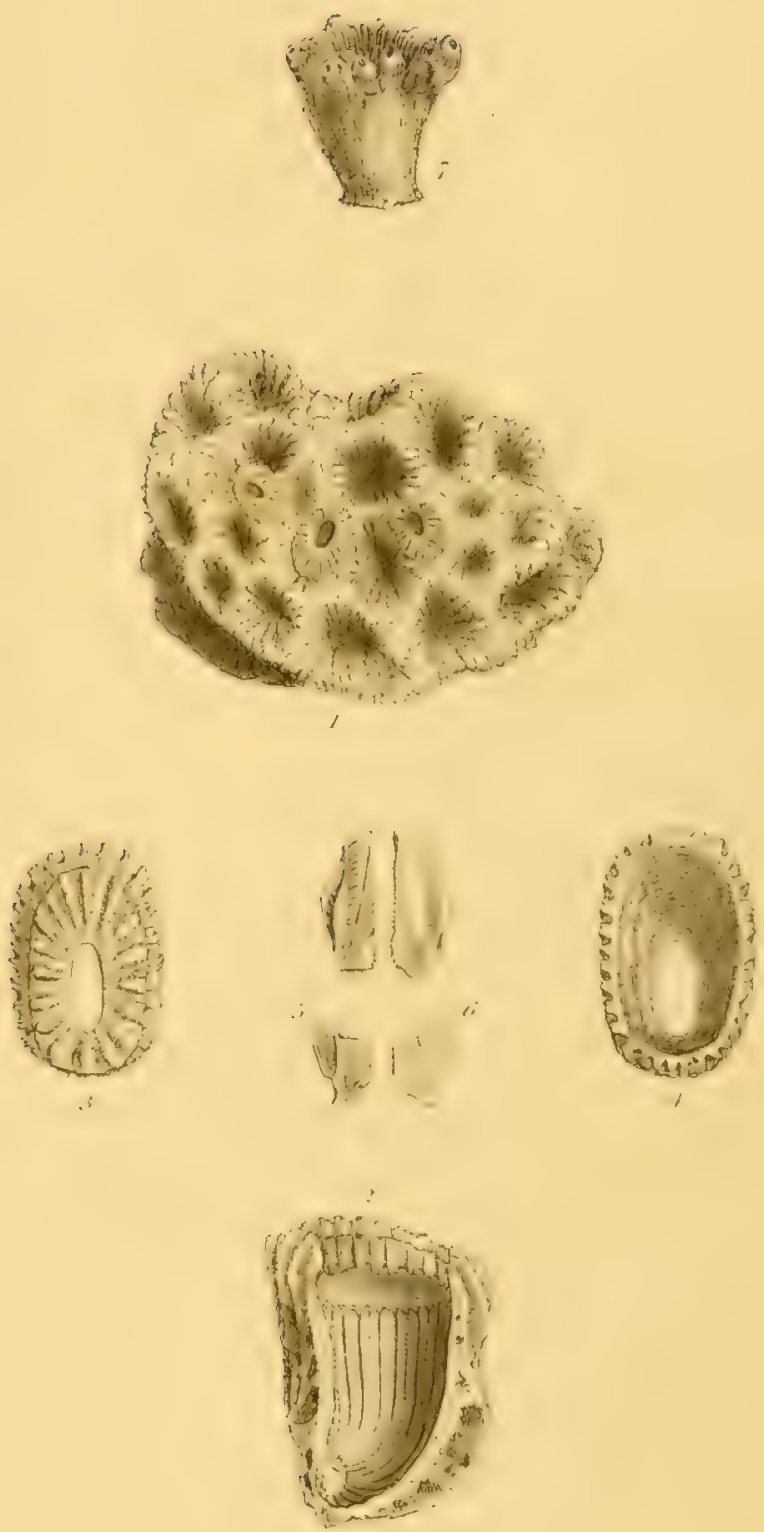

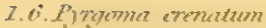

7 ........... explicum. 
by Dr. Leach, Pyrgoma, Megatremu, Sarignium and Adna; these, Low ever, in accordance with the opinion of Sowerby, we have reunited. The chief peculiarity in the shell of Pyrgoma, and in which it differs from all other Sessile Lepades, is in being composed of only one patelifium piece, somerwhat resembling the shell of Fissurellu. Like Creusin it is closed beneath by a grooved, cup-shaped or tubular testaceous base, penetrating to some depth in Coral, which is also its peculiar place of habitation.

\section{Examples.}

PI. X. Fig. 1 to 6.

Pyrgoma crenatum, Sowerby, Genera of Shells, No. 18.

Savignium crenatum, Leach, MSS. Brit. Mus.

$$
\text { Pl. X. Fig. } 7 .
$$

Pyrgoma Anglicum, Sowerby, Genera of Shells, No. 18. Adna Anglica, Leach, MSS. Brit. Mus.

\section{Order II. LEPADES PEDUNCULATA.}

Corpus pedunculo flexili, tendineo, elevatum; ad basem affixo.

There is evidently a strong and peculiar analogy in the organization of the Sessile and Pedunculated Lepades; we are not, therefore, surprised that Linnæus should have considered it sufficient to have included them in one common genus. Since his time, however, the Animal Kingdom has been submitted to a more extended classification; hence, many of the subdivisions that were then considered merely as genera, have been elevated by later writers to the rank of orders.

The Pedunculated Lepades are contained in a thick membranaccous integument, having a greater or less number of testaccous pieces attached to it ; it is open in front for the free passage of the numerous fringed tel1tacular cirri, and mounted upon a tendinous flexible peduncle, adhering 
at the base to some marine body, from which the animal cannot displace it. We include them in the following six genera:

Lithotrya.

Pentelasmis.

Scalpellum.
Pollicipes.

Cinaras.

Otion.

\section{LITHOTRYA, Sowerby.}

'Testa octovalvis, irregulariter subpyramidalis, lateribus compressis, valvis sex contiguis, inæqualibus, lateralibus, inferioribus minimis; valvâ unicâ dorsali magnnâ, ligulatâ; unicâ anticâ minutissimâ; appendice testaceî, patellam inversam referens, ad basem pedunculi. Animal saxorum cavos ab ipso terebratos incolens.

This remarkable Lepas was first described by Sowerby, who considers the animal to be intermediate in its organization between that of the Sessiles and Pedunculati. It is somewhat of an irregular, compressed, pyramidal form, having the top of the peduncle surrounded by rows of very small scales. The shell consists of eight unequal pieces; six are contiguous and lateral, one dorsal, and one anterior, but very small. The peculiar and distinguishing character, however, of Lithotrya is in the appearance of an irregular, testaceous, cup-shaped appendage, resembling the inverted shell of a Patella, to the inside of which the base of the peduncle is attached. This patelliform cup may be considered as analogrous to the testaceous base which characterizes the shell of Balanus, and is always fixed to the bottom of a deep irregular cavity in limestone rock, evidently perforated by the animal.

\section{Example.}

Pl. XI. Fig. 1 to 3.

Lithotrya dorsalis, Sowerby, Genera of Shells, No. 8. Enc. Méth., pl. 166. f. 5 .

Lepas dorsalis, Solander.

Litholepas dorsalis, De Blainville. 
LITHOTRYA.

Plate XI.
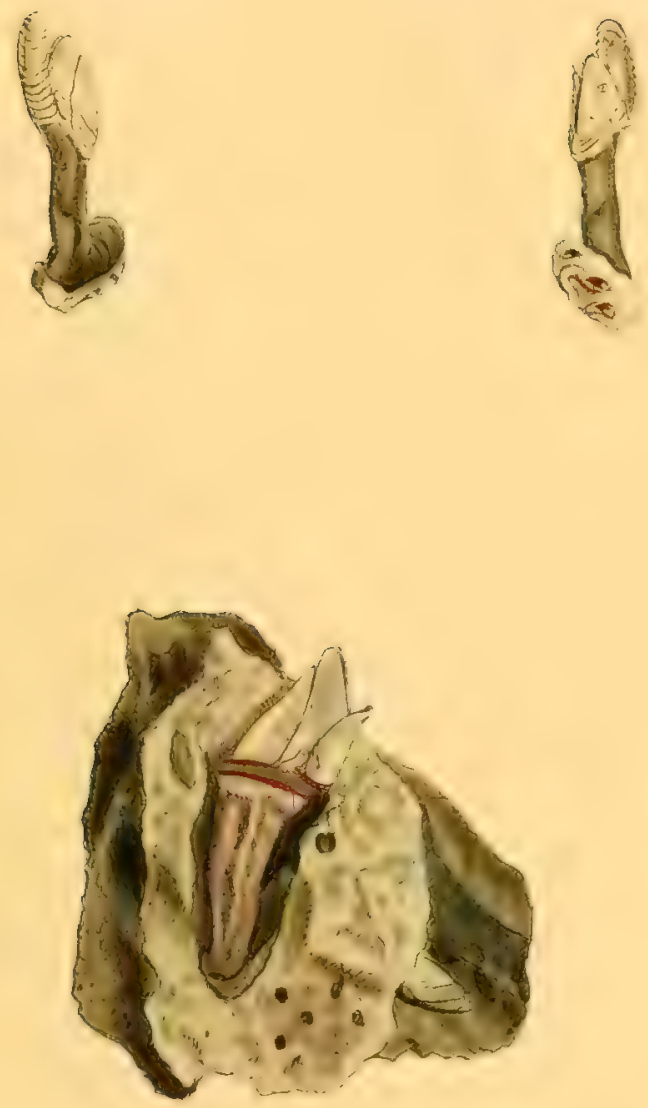

Lithotrya dorsalis. 




$$
18
$$




\section{PENTELASMIS, Leach.}

Testa quinquevalvis, lateribus compressa, valvis contiguis, inxqualibus, basalibus majoribus, subtrigonis, convexiusculis ; valvâ dorsali elongatâ, carinatâ, apice acuto ; valvis superioribus elongato-trapeziformibus ; pedunculo plerumque longissimo, lævi.

As the number of pieces which serve to compose the shell of the Lepas indicate an important generic character, we adopt the above title in preference to that of Anatifa. The shell of Pentelasmis consists of five pieces, compressed at the sides, and adhering to the internal membranaceous integument which contains the body of the animal ; it is supported upon a smooth tendinous peduncle, varying considerably in length, and is found growing in clusters upon timbers, or almost any substance that is covered by the sea.

Example.

PI. XII. Fig. 1, 2.

Pentelasmis anatifera, Leach, Enc. Brit. Supp., vol. iii. p. 170.

Lepas anatifera, Linnæus.

Anatifa lavis, Lamarck.

Anatifa vulgaris, Gray.

Pentalepas lavis, De Blainville.

SCALPELLUM, Leach.

Testa tredecim-valvis, lateraliter compressa; valvis contiguis inæequalibus, duodecim lateralibus, subtriangularibus, unicâ dorsali, elongatâ; pedunculo squamulifero.

'This genus was also introduced by Dr. Leach, and though included by VOL. I. 
Lamarck with Pollicipes, is generally adopted by modern naturalists. Its shell consists of thirteen unequal pieces, twelve of which are lateral and very much flattened or compressed, and one dorsal, elongated and acuminated at the apex. They are all united together on the integument or cartilaginous membrane, and the peduncle upon which the shell is supported is covered with small scales. The genus Smilium of Leach and Gray may possibly be distinct; but as the shell appears to differ only in the arrangement of the pieces, and the peduncle in being covered with hair instead of scales, we have not ventured to adopt it.

\section{Extumple.}

Pl. XIII. Fig. 1, 2.

Scalpellum vulgare, Leach, Enc. Brit. Supp., vol. iii.p.170. pl.57. f. I. Lepas scalpellum, Linnæus.

Anatifa scalpellum, Bruguière.

Pollicipes scalpellum, Lamarck.

Polylepas vulgaris, De Blainville.

POLLICIPES, Hill.

Testa multivalvis, lateraliter subcompressa ; valvis quinque superioribus majoribus, cæteris inferioribus minimis, omnibus supernè acutis; pedunculo squamulifero.

The genera Pollicipes of Hill and Capitulum of Klein have been united under the former title by Leach, Lamarck, Sowerby, and other modern naturalists; they are both, however, retained by Gray, who has also formed a new genus, Calantica, of the P.tomentosus and hispidus of Leach.

The shell of Pollicipes consists of tive principal elongated trapeziform pieces, surrounded with a number of smaller ones similarly shaped; they are all sharp-pointed at the apex, and form together an irregular laterally-compressed cone, which is supported on a thick, scaly, coria- 
SCALPELIUUM.

Plate XIII.
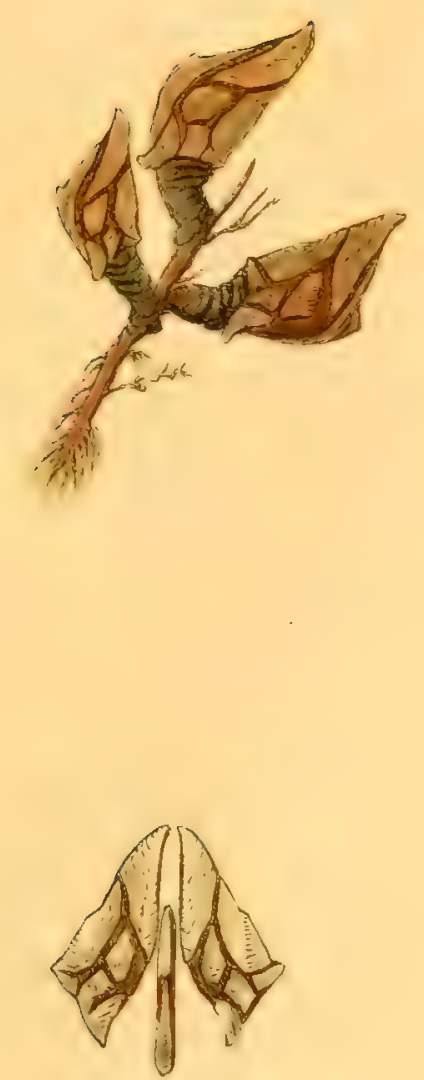


POLLICIPES

Plate XIV.
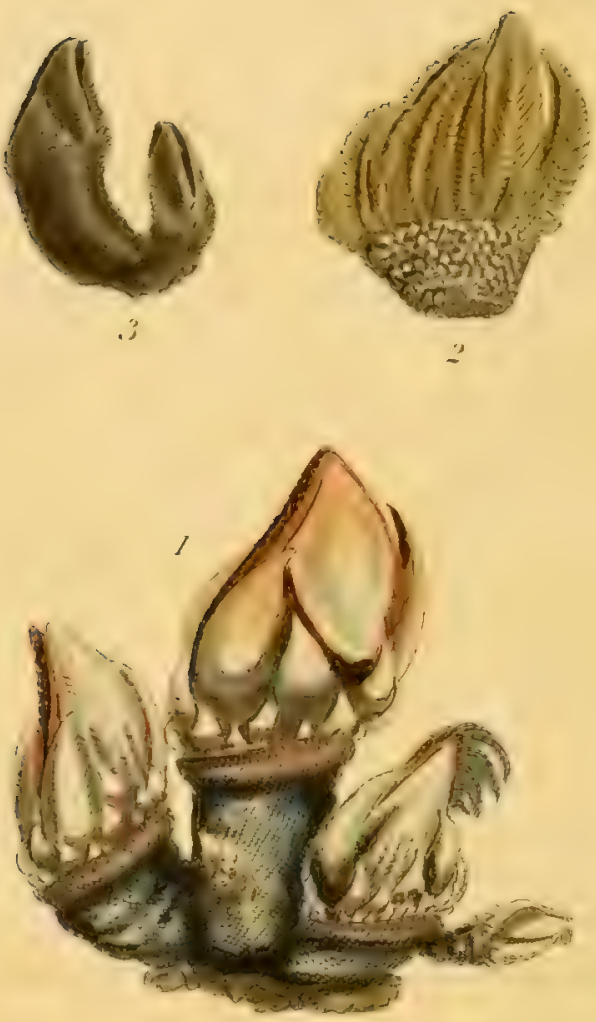

1. Pollicipes Comucopire.

2. Miteller.
3.
villoszis. 
ceous peduncle. It is found in groups upon the rocks, but though common, is not so prolific as the Pentelasmis.

Examples.

Pl. XIV. Fig. 1.

Pollicipes cornucopia, Leach, Enc. Brit. Supp., vol. iii.

Lepas pollicipes, Linnæus.

Anatifa pollicipes, Bruguière.

Pentalepas pollicipes, De Blainville.

\section{Pl. XIV. Fig. 2.}

Pollicipes mitella, Leach, Enc. Brit. Supp., vol. iii.

Lepas mitella, Linnæus.

Anatifa mitella, Bruguière.

Polylepas mitella, De Blainville.

Capitulum mitella, Klein.

PI. XIV. Fig. 3.

Pollicipes villosus, Leach, Enc. Brit. Supp., vol. iii. Sowerby, Genera of Shells, No. 27.

Anatifa villosa, Lamarck.

CINARAS, Leach.

Corpus pedunculatum, tunić́ membranaceá penitus obvolutum, tunicâ supernè turgidâ, infrà apicem anticè aperturâ hiante; valvis testaceis quinque oblongis, separatis, corpus non penitìs tegentibus, duabus ad latera aperturæ, unicâ dorsali, cæeteris terminalibus.

This and the following genus, both of which were instituted by $\mathrm{Dr}$. Leach, are remarkable on account of the very small portion of testaceous matter produced by the animal, particularly the latter. The Cinaras, which Sowerby aptly terms a pedunculate body, is entirely enveloped in E 2 
a thick membranaceous integument, with a large anterior opening at the top for the passage of the cirri, it being, in fact, merely a wide clavate elongation of the peduncle. There are five oblong testaceous pieces attached to this clarate integument; they are small, narrow, and distant from each other; two are situated at the sides of the aperture, one dorsal, and the rest terminal.

\section{Example. \\ Pl. XV. Fig. 1 to 4.}

Cinaras vittatus, Leach, Enc. Brit., vol. iii.p. 170. pl. 57.

Lepas membranacea, Montague.

Senoclita fasciata, Schumacher.

Gymnolepas vittatus, De Blainville.

\section{OTION, Leach.}

Corpus pedunculatum, tunicâ membranaceâ, abruptè ventricosâ, supernè obtectum, anticè aperturâ hiante. Tubi duo subcylindrici, retrorsùm versi, truncati, extremitate pervii, ad apicem tunicæ. Valva testacex quinque, separatx, dux semilunatie ad latera aperturx, unica minutissima dorsalis, cæteræ paritèr minutissimæ, terminales.

As in the preceding genus, the body of the animal is entirely enveloped in a thick, pedunculate, membranaceous integument, with an aperture at the top for the passage of the cirri; behind it, however, and this forms the peculiar character of the genus, are two irregularly cylindrical tubes, varying in size in different species. The Otion has five testaceous pieces, very small, and distant from each other, attached to the outer surface of the integument, as in Cinaras; they have been entirely overlooked by Lamarck, but Dr. Leach has not failed to observe them.

In the course of our observations on the Lepades, it will be readily 
CINARAS.

\section{Plite XV.}
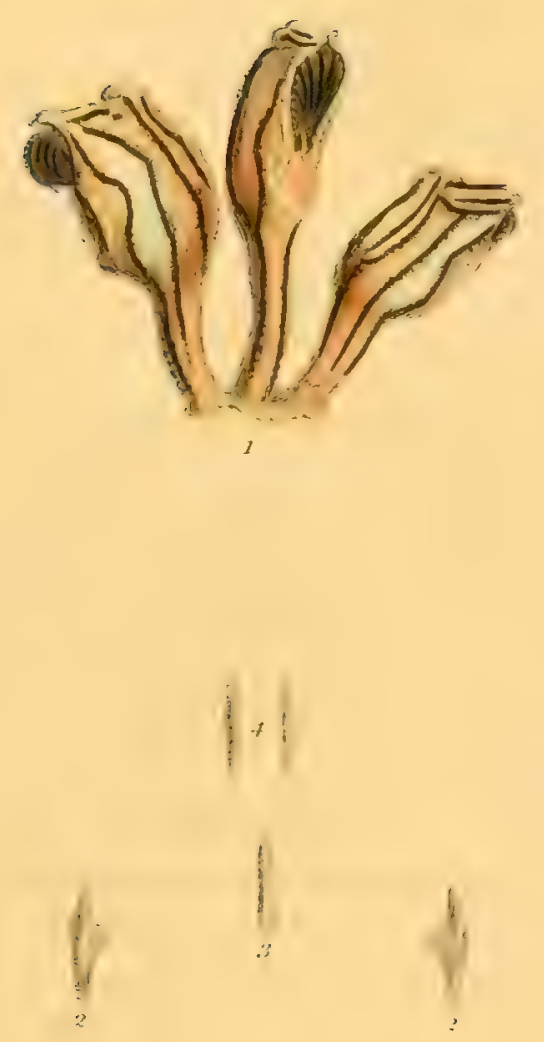

Cimaras vitatas 


OTION.

Plate XVI.

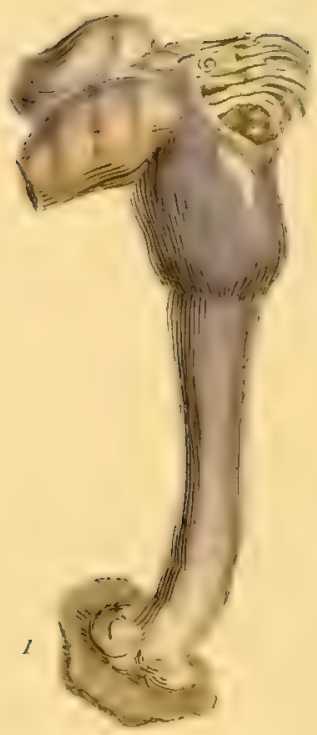

4

3

2 
noted how much we are indebted to our worthy countryman for his elaborate distribution of these singular animals; their distinguishing characters have been seized upon with considerable skill, and have powerfully aided in completing their present natural arrangement.

Example.

Pl. XVI. Fig. I to 4.

Otion Cuvierii, Leach, Enc. Brit. Supp., vol. iii. p. 170. pl. 57.

Lepas aurita, Linnæus.

Gymnolepas Cuvierii, De Blainville.

Malacota bivalvis, Schumacher. 


\section{MOLLUSCA CONCHIFERA*.}

Axmalia mollia, inarticulata, pallio amplo instructa, per branchias respirantia, testî calcareâ à fluido mucoso gradatim perfectâ, partim vel totaliter tecta.

The Conchiferous. Mollusca constitute a vast series of animals exhibiting the highest degree of organization of those which are without skeleton or vertebri. They are characterized as being furnished with a large fleshy mantle, and are either wholly or partially covered with a calcareous shell, which is gradually formed by the secretion of a mucous fluid, which becomes hardened on the body.

The organ of locomotion, which is selected to characterize the primary distribution of the Mollusca, serves to divide them into five classes as follows, under each of which their general physiology will be detailed:

TROPIOPODA.

BRACHIOPODA.

GASTEROPODA.

PTEROPODA.

CEPHALOPODA.

\section{Class I. TROPIOPODA.}

Animal in testa bivalvi perpetuò affixum, capite oculisque nullis; ore nudo, abscondito, partibus solidis nullis; pallio amplo corpus to-

* It is obvious that this word is used to distinguish the shell-bearing from the naked Mollusec. Lamarck applies the term "Conchifera" to the bivalve Mollusca only; in fact, its derivative is so rendered by some authors; it however frequently occurs in the ancient poets in reference to the Trumpet Shell (Triton $t u b a$ ) and other univalves. 
tum amplectente, lobos duos laminiformes formante, laminis vel liberis vel anticè coadunatis. Branchia externa intrà corpus et pallium reconditæ. Circulatio simplex corde uniloculari.

Testa semper bivalvis, modò libera, modò affixa; valvis cardine cum ligamento vel externo vel interno conjunctis; partibus testaceis accessoriis, valvis alienis, testam interdum amplificantibus.

The Tropiopoda or keel-footed Mollusca, the Acephala of Cuvier, the Conchifera of Lamarck, constitute a numerous and well-clefined class of soft inarticulated animals, having the body enveloped in a large mantle forming two laminiform lobes, each of which is protected by a sepraite testaceous valve, hinging either externally or interually by means of a strong dorsal horny cartilage or ligament. The animal is entirely destitute of head or eyes, but is provicied with a mouth, situated behind the union of the lobes of the mantle; and the lower part of the body is dilated into a keel-shaped foot, giving it full power of locomotion, when not attached to any marine substance; it is obvious, however, that in so extensive a series of animals, this organ passes through a considerable modification of form. The branchia are large, rascular and crescentshaped, placed on each side between the body and the bilobed mantle; and there exists a perfect system of circulation, performed by a small heart composed of a single ventricle. The lobes of the mantle are fringed round the edge with numerous tentacular filaments, very sensitive and irritable to the touch, and in constant activity, drawing a current of water within for the capture of prey. There appears to be no distinction of sex, the animal being hermaphrodite.

The shell of the Tropiopoda is always essentially bivalve, composed of two opposite pieces or valves, joined internally or extemally near their dorsal edges, by means of a strong coriaceous cartilaginous ligament, the elasticity of which tends to open the valves, in opposition to the cor:tractile action of the adductor muscle, by which they are internaliy attached to the animal. They are equal or unequal, close or gaping, and generally furnished on the dorsal margin with numerous denticulations closely interlocking with each other. These denticulations are techni- 
cally called teeth, and, together with the number and position of the muscular points of attachment, chiefly serve to fix the classification.

All the Tropiopoda are aquatic, either marine or fluviatile; they live buried in the sand, or in cavities of rocks; some move about entirely free, and others are either fixed immediately upon different marine bodies, or are attached by a byssus of fibrous or silken filaments.

The cicatrices exhibited in the interior of the valves, indicating the points of muscular attachment, are either two in number and lateral, or one and subcentral, and have been selected for the division of this class into two orders as follows:

\section{Bimusculosa. \\ Unimusculosa.}

\section{Order I. TROPIOPODA BIMUSCULOSA.}

Testa, musculorum impressionibus duabus, distantibus, lateralibus, internè imbuta.

This order includes all the Tropiopodous Mollusca, in which the animal is bimuscular, or attached to its shell by two adductor muscles, the marks of which attachment are exhibited in the interior, at the lateral extremities of each valve.

They are distributed according to their natural affinities into thirteen families, as follows:

$\begin{array}{ll}\text { Tubicola. } & \text { Conchacea. } \\ \text { Pholadaria. } & \text { Cardiacea. } \\ \text { Solenacea. } & \text { Arcacea. } \\ \text { Mraria. } & \text { Trigonacea. } \\ \text { Mactracea. } & \text { Naiades. } \\ \text { Lithophaga. } & \text { Chamacea. } \\ \text { Nymphacea. } & \end{array}$




\section{Family 1. TUBICOLA.}

Testa vaginâ testaceâ tubulosâ munita, vel libera, vel vaginæ pariete partim aut totaliter incrustata.

The animal of the Tubicola is furnished with a small bivalve shell, either entirely free, or partially or wholly imbedded within the substance of a testaceous tube. This tube does not appear to form an immediate part of the organization of the animal, but merely an accessory though important agent in protecting its inhabitant.

The Tubicola are often found buried in wood, but are for the most part lithophagous; the holes and cavities in which they live are evidently perforated by the animal, assisted no doubt by a powerful solvent secretion from the glands, as they do not appear to be the result of mechanical attrition. We refer the following five genera to this family :

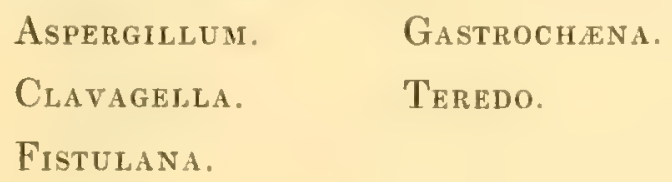

ASPERGILLUM, Bruguière.

Testa æequivalvis, subæquilateralis, in pariete inferiori tubi testacei omninò conferruminata, umbonibus extrà tubum subprominulis; tubo infernè clauso, disco terminali poris minimis numerosis fissurique centrali perforato, margine tubulis minimis plerumque circumcincto; supernè elongato, plus minusve attenuato, pervio, margine plerumque reflexo, undulatim fimbriato.

The Aspergillum had long been a source of embarrassment to early naturalists, who with Linnæus had, from the tubular appearance of its VOL. I. 
shell, placed it with the Serpulacea, a family of testaceous Annelides. Lamarck, however, observed that a small bivalve shell was evidently imbedded or grown in with the substance of the tube; and although the anatomy of the animal and its true mode of habitation still remain in comparative obscurity, the analogy of its structure to other and better known tubicolar Tropiopoda sufficiently indicate the propriety of its arrangement in this family.

The shell of Aspergillum may be described as being oval, equivalve, and nearly equilateral; it always remains open, is supposed to cover a portion of the back of the animal, and in this position becomes imbedded at the lower side of a long clavate testaceous tube, so that the umbones and complete form of it may be distinctly traced on the outer surface; the tube is then immediately closed over by a convex disc, perforated with numerous tubular holes, like the rose of a common watering-pot; there is also a small fissure in the centre, and the margin is surrounded by a circular frill or row of tubes, supposed during the life of the animal to be filled with fleshy filaments from the mantle. The upper end of the tube, which is rarely obtained perfect, is more or less attenuated, and, terminating in smooth undulations, is reflected at the margin; sometimes, however, it is straight, and somewhat inclined to be compressed. This reflected extremity is left entire at certain periods of growth, and the tube is recommenced according to the necessities of the animal; some specimens have been found with four or five of these entire terminal reflections; that from which our figure is drawn exhibits four.

\section{Examples.}

PI. XVII. Fig. 1, 2.

Aspergillum vaginiferum, Lamarck, Anim. sans vert., vol. vi. p. 11. Sowerby, Genera of Shells, No. 27.

Pl. XVII. Fig. 3, 4 and 5.

Aspergillum sparsum, Sowerby, Genera of Shells, No. 27. Aspergillum Javanum, Lamarck? 
ASPERGIJLUM.

Plate XV1I.
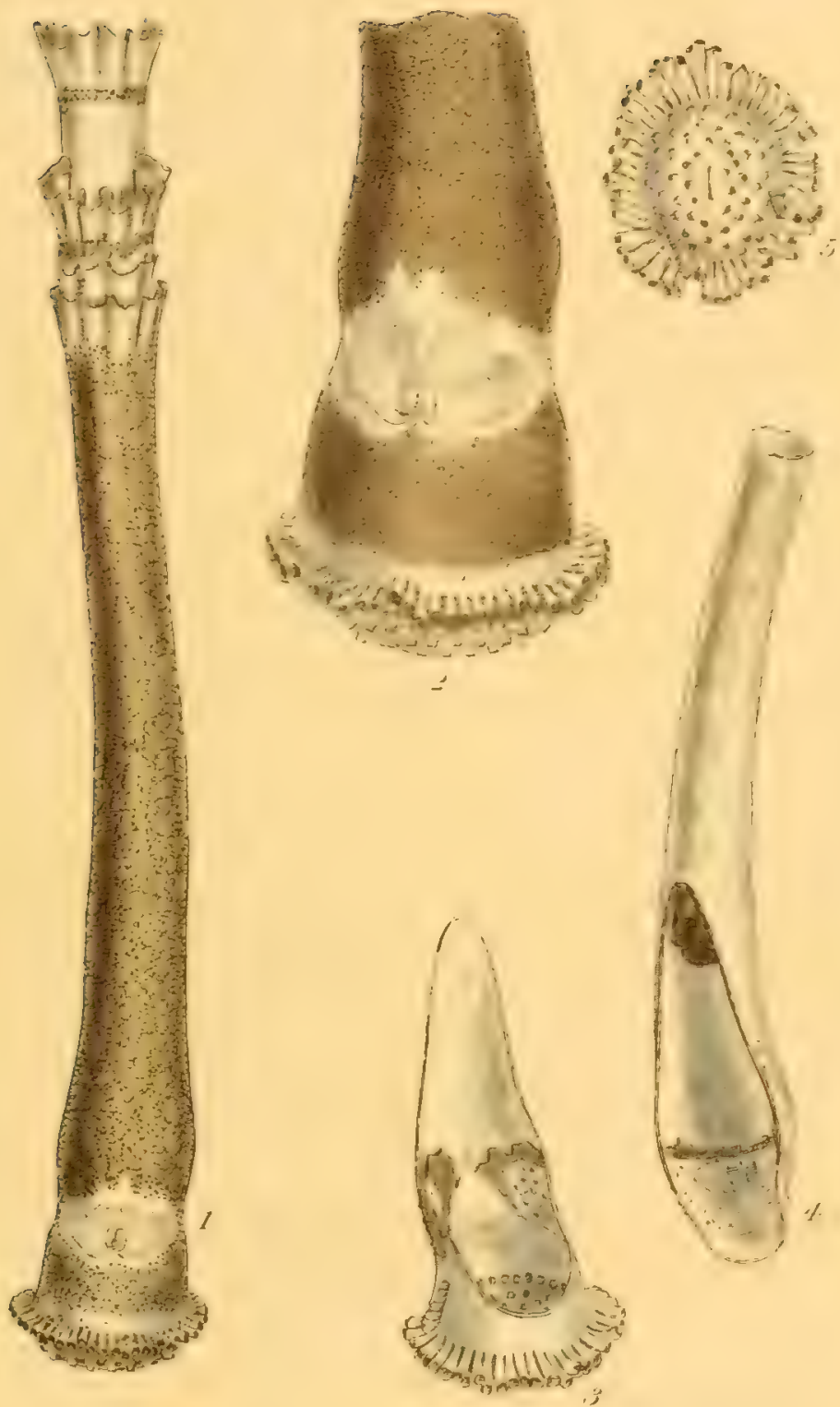

Fig.1.2.Aspergillum "usinifimme.

3.4 .5 .

cyecsum? 

Serpula penis, Linnæeus.

Serpula aquaria, Dillwyn.

Penicillus Javanus, Bruguière.

CLAVAGELLA, Lamarck.

Testa inæquivalvis, inæquilateralis; valvâ alterâ in pariete inferiori tubi testacei conferruminatâ, alterâ liberâ intrà tubum testaceum ad musculum animalis adhærente; tubo infernè in clavam ovatam, vel cameram subcompressam, tubulis spiniforınis irregularibus echinatam, terminato; supernè subattenuato et aperto, margine latè reflexo.

The Clavagella is an animal of considerable interest and importance, as it forms a remarkable link between the Aspergillum and Fistulana, confirning the propriety of arranging the former with the Tubicola. In Aspergillum, as we have already noted, the bivalve shell is entirely imbedded in the side of the tube; in Fistulana it will be observed that the shell is altogether free within the tube and quite independent of it ; but in Clavagella, one valve of the shell is imbedded in the side of the tube, and the other free or independent of it, attached to the muscle of the animal : thus we have clearly an intermediate form partaking of the principal characters of each of those genera.

The tube of Clavagella, which is found buried in stone with the clavate or chambered end downwards, has a kind of perforated plate inserted at the bottom, analogous to the terminal disc of the tube in Aspergillum; it is also surrounded with minute spiniform tubes, probably filled also with certain fleshy filaments of the mantle: at the side of this chamber is imbedded the fixed valve, somewhat pearly in appearance; and attached to the animal by two strong adductor muscles is the corresponding one, hinging upon the other by a soft coriaceous ligament. 
Example.

PI. XVIII. Fig. 1 to 4.

Clavagella aperta, Sowerby, Genera of Shells, No. 13. Deshayes, Enc. Méth., vol. ii. p. 240.

\section{FISTULANA, Bruguière.}

'lesta aquivalvis, maeguilateralis, ad marginem basalem hiantissma, latere antico brevissimo; in parte inferiori tubi testacei inclusa; tubo infernè clauso, supernè perforato, attenuato.

In the grenus Fistulana the bivalve shell is altogether free, and independent of the tube in which it is confined; and the lower end of the tube is convexly closed over. Only two of Lamarck's species are referable to this genus, his Fistulance clave and gregata; the rest belong to the genera Gastrochona and Teredo.

The shell of Fistulana consists of two irregular, inequilateral valves, gaping widely at the basal margin, and united by a soft liganent. It is entirely free, inclosed in the lower expanded cavity of a long, straicht, clavate tube which it forms in the sand: the lower end is closed, the upper end open.

\section{Example.}

PI. XIX. Fig. 1 to 5.

Fistulana clava, Lamarck, Anim. sans vert, new edit, vol. vi. p. 30. Enc. Méth., vol. ii. p. 140. pl. 167.f. 17 to 22. Teredo clava, Gmelin.

\section{GASTROCH ENA, Spengler.}

Testa aquivalvis, inæquilateralis, subcuneiformis, anticè hiantissima ; hiatu ovali, posticè attenuato; cardine lineari, marginali, subeden- 
CIAVAGELIAA.

Plate XVIII.

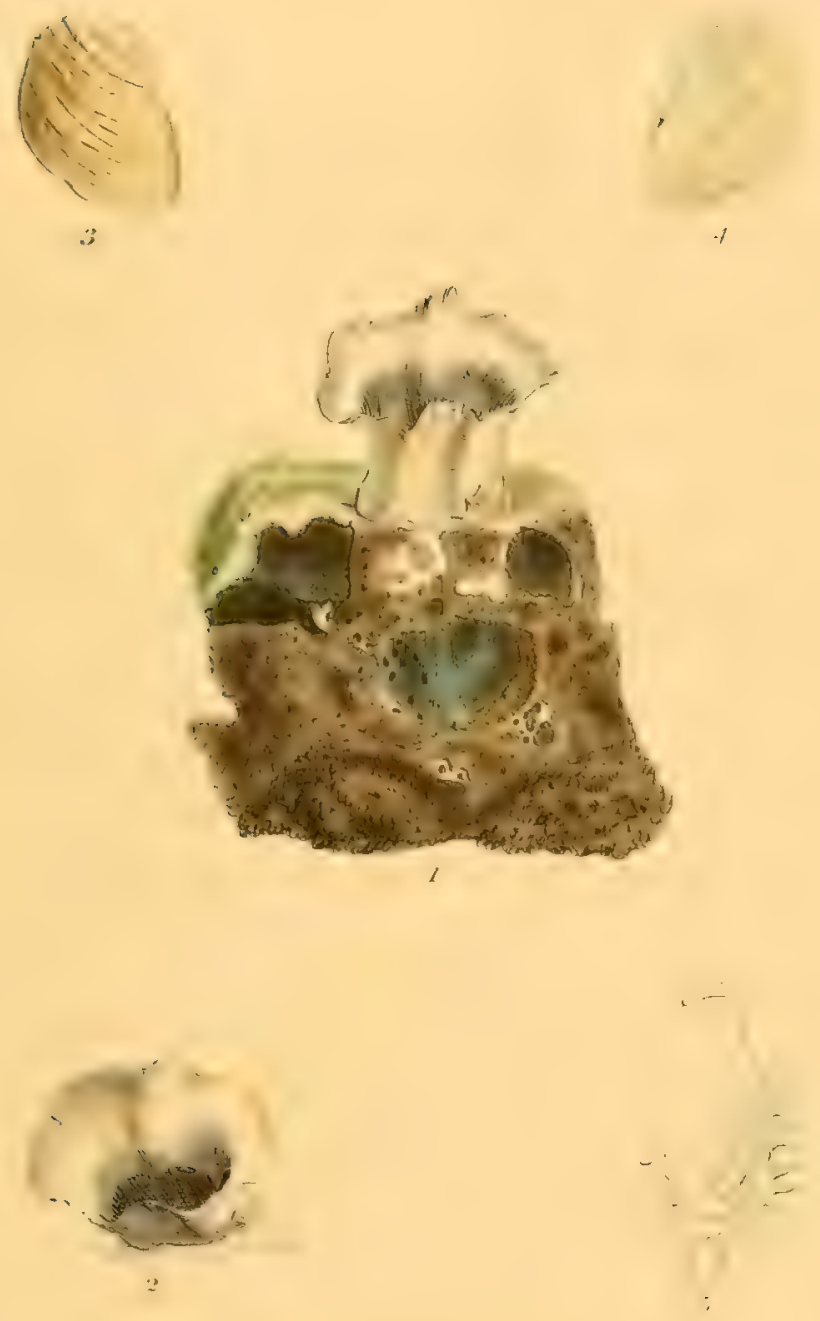





$$
|:|
$$




GASTROCH ENA.

Plate XX.
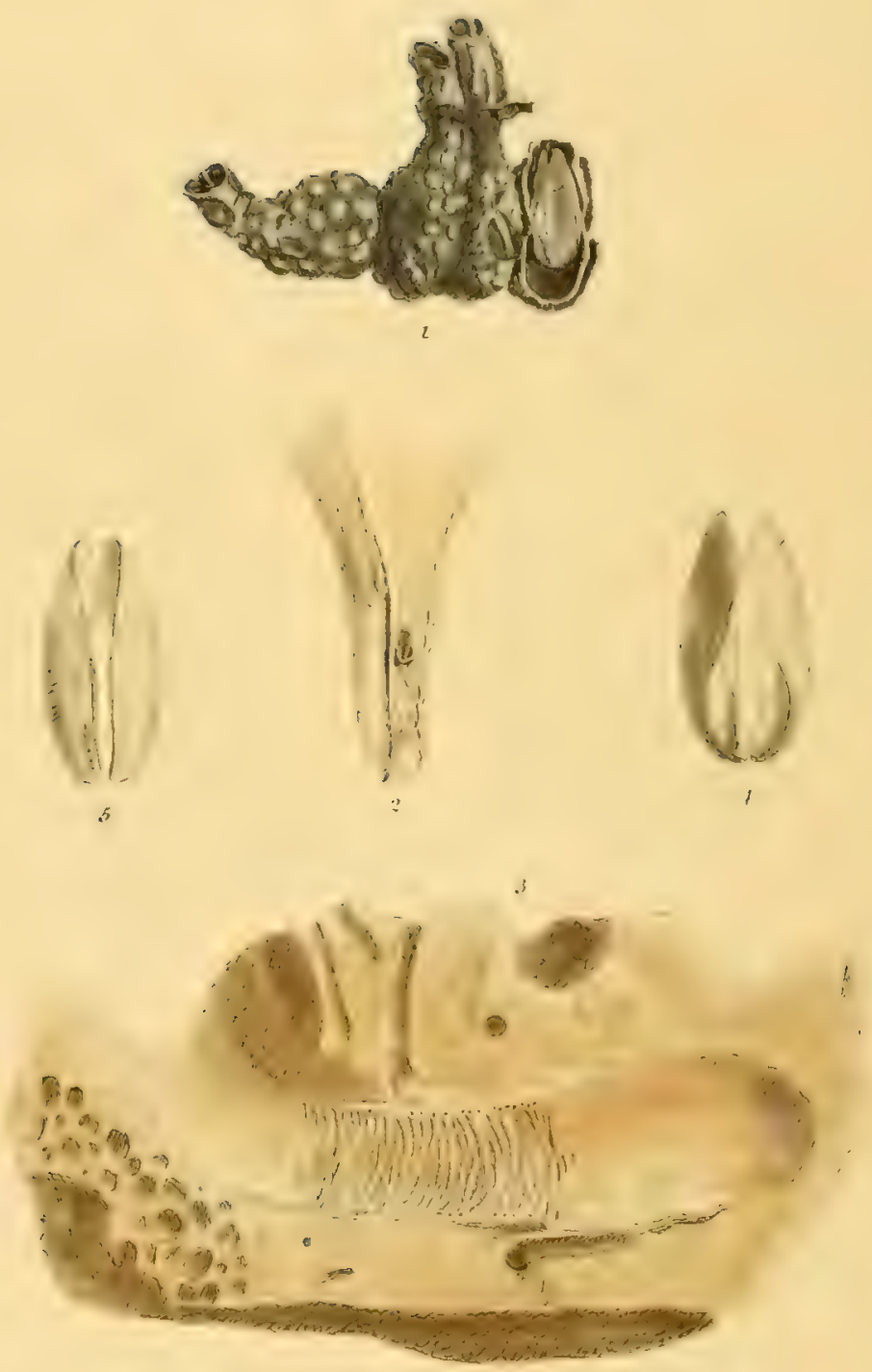

2. Cinstrodiona motiolina.

$3+$ is cameiformis. 
tulo; tubo testaceo supernè attenuato, aperto, aperturî bilobatâ ; infernè in clavam ovatam, clausam, terminum habente.

The genus Gastrochana has been removed from the Pholadarin to the Tubicola, because, like the rest of this family, the animal lines with a testaceous tube the cavity in which it dwells; it also forms an unconnected tube for protection, when not imbedded. Its shell is equivalve, inequilateral, gaping very widely on the anterior side in the form of an oblong oval, united by a ligament behind, and having in the interior a small spoon-shaped curvature; a character which becomes more fully developed in the shells of Teredo and Pholas.

The tube differs from that of Fistuluna in being nearly divided into two, at the upper end, by a kind of septum ; as also in its mode of habitation, being often found in the open parts of dead shells, in which case it forms a complete testaceous covering entirely foreign to its place of attachment.

\section{Examples.}

PI. XX. Fig. 1 and 2.

Gastrochena modiolina, Lamarck, Anim. sans vert., new edit., vol. vi. p. 49.

Fistulana modiolina, Deshayes.

Mya dubia, Pennant.

Pl. XX. Fig. 3 to 5.

Gastrochana cuneiformis, Lamarck, Anim. sans vert., new edit., vol.vi. p. 49.

Fistulana cunєiformis, Deshayes.

Pholas hians, Chemnitz.

TEREDO, Linnæus.

Testa orbicularis, inæquilateralis, ad utrumque latus hians, dente elongato, recurvo, infrà marginem umbonalem utriusque valva promi- 
nente; tubo accessorio longissimo, internè septis numerosis sæè cameratim diviso, extremitate anticâ rariùs clausâ, posticâ in tubulis duobus terminum habente, operculis duobus palmatis, aliquando pennatis, instructis.

The marked attention which Sowerby has given to the distribution of this family readily induces us to admit the propriety of his observations on the Teredo, in which he successfully proves that the Septaria arenaria of Lamarck belongs to this genus: its gigantic proportions are certainly remarkable, but the character which is cited by the latter of the "vaulted septa" is evidently common to both.

In this genus of Tubicola the animal presents another distinct modification of character; as in Fistulana, its shell is entirely free and independent of the tube, but it differs from that genus in being external. From its mode of habitation it appears to have immense power of terebrating or boring, and the tube is formed by a secretion of calcareous matter lining the perforation as it advances.

The shell of Teredo may be described as orbicular, inequilateral, gaping at both sides, and having a long recurved tooth standing out from beneath the umbonal margin of each valve : the accessory tube is very long, and often internally divided into chambers by numerous septa: the anterior end is sometimes, but rarely, covered over, and the posterior terminates with two smaller tubes, which are closed at the will of the animal by two palmate, sometimes pennated, opercula.

This animal is remarkably destructive, piercing any timber that is covered by the sea in every direction, and so completely intersecting it, that immense piles and foundations have been quite undermined.

\section{Example.}

Pl. XXI. Fig. 1 to 4.

Teredo Navalis, Linnaus, Syst. Nat,, p. 1267. Enc. Méth., pl. 167. f. 1 to 5 . 
TEREDO.

Plate XXI.
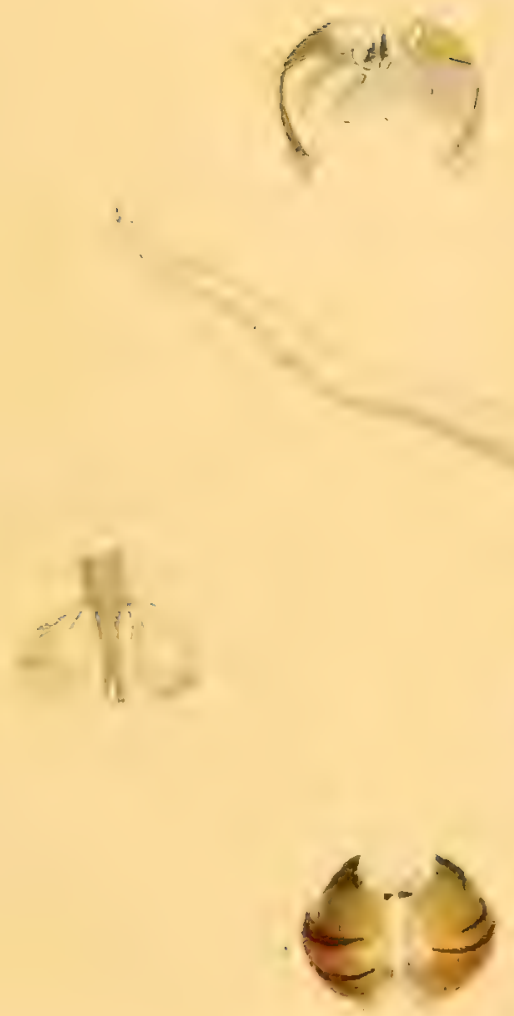

rerede meneltis: 



\section{Family 2. PHOLADARIA.}

Testa tubo nullo, sed partibus accessoriis testaceis sæepiìs instructa, anticè hiantissima.

This is another family of terebrating Tropiopoda, closely allied to the Tubicola, but differing in as much as the animal does not form a testaceous tube; yet, although it is wanting, some analogy may be traced in the appearance of certain accessory testaceous pieces, entirely foreign to the shell, varying in size and number according to circumstances: in some species there is also a coriaceous or horny tubular appendage at one end. We include but two genera,

XYlophaga.

Pholas.

\section{XYLOPHAGA, Turton.}

Testa orbicularis, æquivalvis, inæquilateralis, anticè hians, partibus accessoriis testaceis duabus, subtrigonis, dente cardinali minuto costîque internî, ab umbone ad marginem basalem utriusque valvæ decurrente. Impressiones musculares duo; postica magna, obovata; antica minor, margini superiori imbuta.

The shell of Xylophaga approximates closely in its general structure to that of the last genus of Tubicola; the valves being equal, inequilateral and very much gaping, are very similar in form to those of Teredo, but in place of the calcareous tube, they are merely furnished with two small accessory calyciform testaceous pieces, placed on the anterior side of the hinge. There is a small curved tooth in each valve, with an internal rib running from the umbo to the basal margin; and there are 
two distinct muscular impressions, the posterior large, the anterior smaller, situated near the edge of the superior margin. The Xylophaya is generally found in light wood or pieces of stick, which it penetrates to the depth of about an inch.

\section{Example.}

Pl. XXII. Fig. 1 to 4.

Xylophaga dorsalis, Turton. Sowerby, Genera of Shells, No. 29.

Pholas xylophaga, Deshayes.

Xylotrya dorsalis, Leach.

\section{PHOLAS, Linnæus.}

Testa transversa, oblonga, æequivalvis, inæequilateralis, utroque latere hians, hiatu antico plerumque maximo, interdum ferè clauso, partihus accessoriis testaceis difformibus suprì vel infrà sapiù instructa. Cardo dente longo, curvo, in utrâque valvâ infrà marginem umbonalem prominente.

The Pholades constitute one of the few genera established by Linnous that remain nearly entire; the construction of their shells, together with the halits of the animal, being so peculiar and distinct, as not to admit of further subdivision.

The shell of Pholas is equivalve, transversely oblong, very inequilateral, and gaping more or less at both ends; the dorsal margin, being very much reflected back, is generally divided by numerous transverse septa, and from within the umbo of each valve proceeds a strong, spoon-shaped curvature or tooth. The external surface of the shell is uniformly of a delicate white colour, generally crossed longitudinally and transversely with fine muricated strix. The accessory pieces are irregular in number as wcll as in their place of attachment, being formed 
XYLOPHAGA.

Plate XXII.
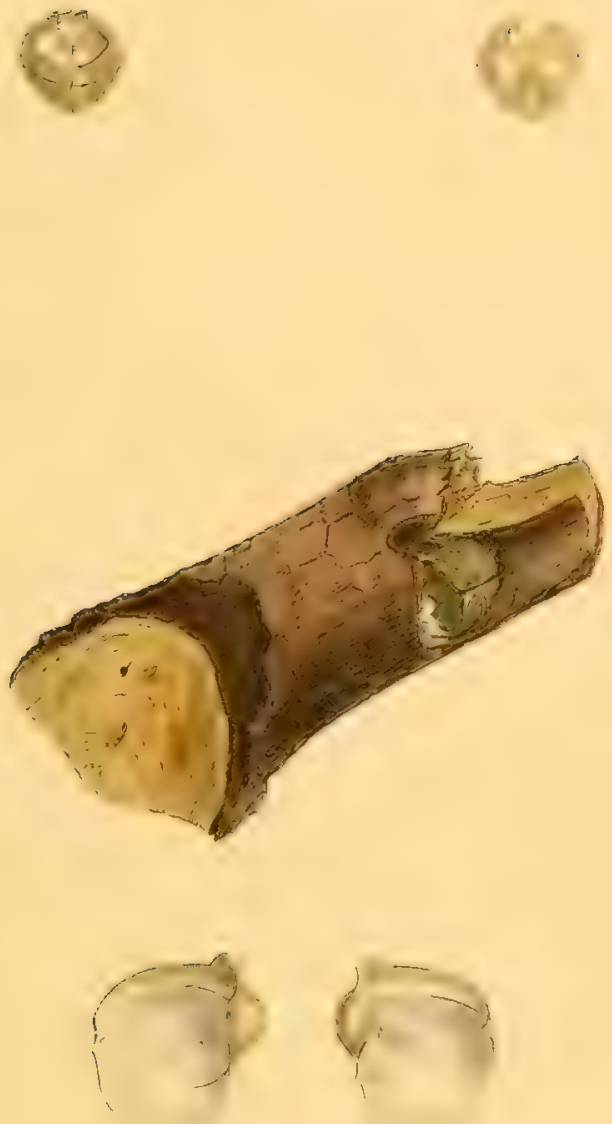

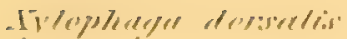




PIIOLAS.

Plate XXIII.
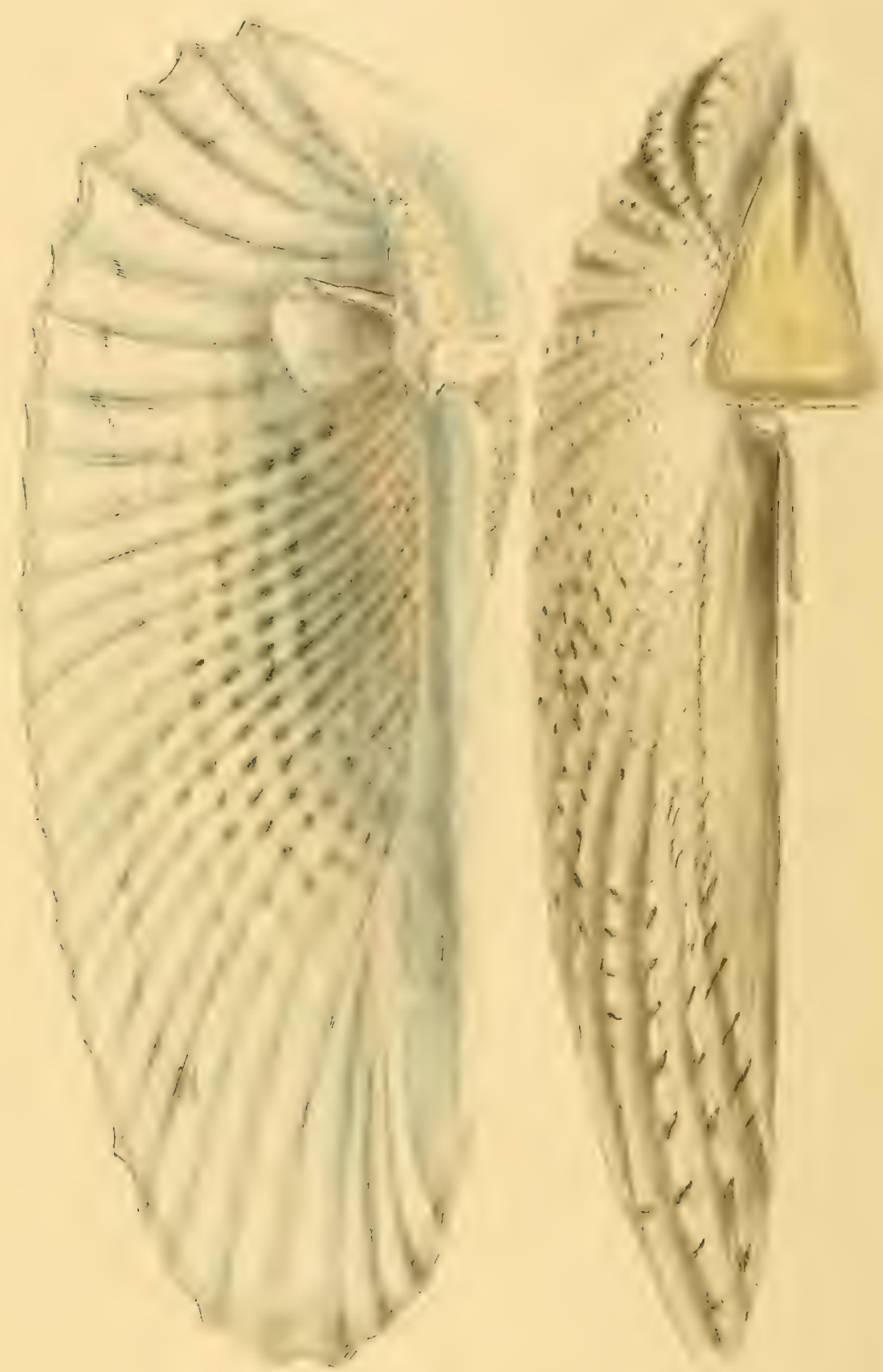

PHOLAS.

Plate XXIV.
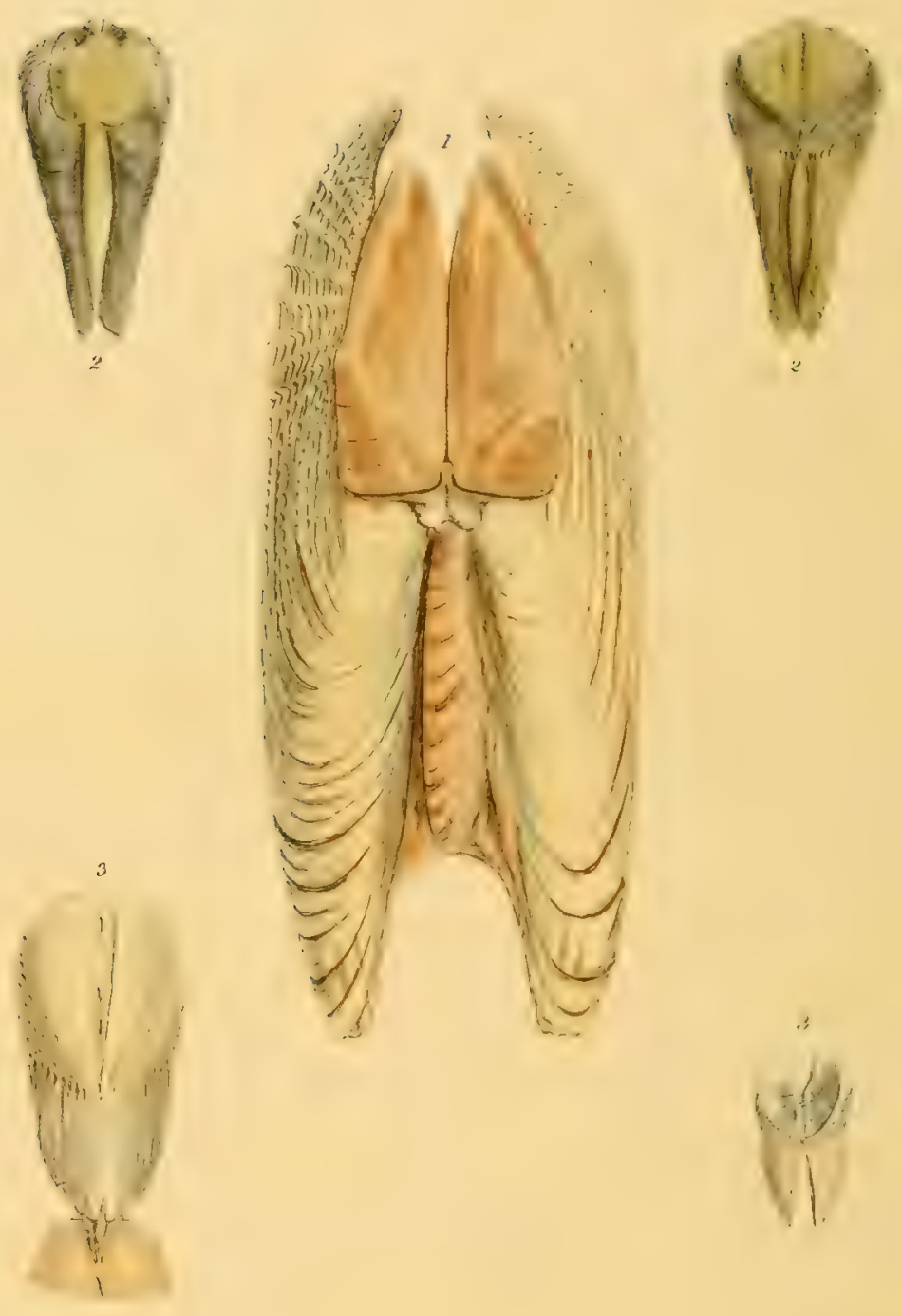
within or on any part that requires protection, according to the necessities of the animal. They are therefore mostly found over the hinge, as it is still a matter of doubt whether the Pholas forms any permanent ligament.

From the circumstance of the Pholades being found to inhabit the hardest descriptions of calcareous rocks, we are led to suppose that the cavities in which they dwell are formed by the aid of some powerfully solvent secretion, operating with the constant current of water around the shell, as the fine strix on its surface disprove that there is any rotatory motion. This current, which is necessary to the existence of the animal, is said to be produced by the incessant motion of minute vibratile cilia, which cover not only the whole of the branchiæ, but other parts of the body*.

\section{Examples.}

Pl. XXIII. Fig. 1 and 2.

Pholas costata, Linnæus, Syst. Nat., p. 1111 . Lamarck, Anim. sans vert., new edit., vol. vi. p. 45. Enc. Méth., pl. 169. f. 1, 2.

\section{Pl. XXIV. Fig. 1.}

Pholas dactylus, Linnæus, Syst. Nat. p. 11 i0. Lamarck, Anim. sans vert., new edit, vol. vi. p. 43. Enc. Méth., pl. 168. f. 4.

\section{Pl. XXIV. Fig. 2.}

Pholas striata, Sowerby, Genera of Shells, No. 23.

PI. XXIV. Fig. 3.

Pholas papyracea, Sowerby, Genera of Shells, No. 23.

* For further observations on the terebrating property of the Mollusca, see note on Saxicava, page 71 .

VOL. I. 


\section{Family 3. SOLENACEA.}

Testa transversim elongata, partibus testaceis accessoriis nullis, utrâque extremitate plerumque hians; interdum appendice testaceâ fixî sub umbone utriusque valvæ.

The shell of the Solenacen, though generally elongated or cylindrical, varies considerably in form, as also in the number and position of the teeth, which in some instances are wholly wanting. It is generally gaping at both ends, the ligament is external, and in some species there is a fixed testaceous appendage under the umbo of each valve, called the fulcrum.

The Solenacea are not lithophagous, nor have they the accessory pieces of the Pholuduria; but if any analogy may be traced in their habits, it is because they bury themselves to a considerable depth in the sand. We include eight genera in this family, as follows :

$\begin{array}{ll}\text { Solen. } & \text { Solemya. } \\ \text { Solecurtus. } & \text { Solenella. } \\ \text { Panopea } & \text { Glauconome. } \\ \text { Glycimeris. } & \text { Pholadomya. }\end{array}$

SOLEN, Linnæus.

Testa æquivalvis, linearis, egregiè inæequilateralis, utrâque extremitate hians; anticâ brevissimâ, subtruncatâ, vel subrotundatâ. Dentes cardinales parvi, varii, posterior bifidus, plerumque recurvus; interdum dens lateralis, elongatus. Impressiones musculares distantes, antica ligulata sub rel post umbonem posita, postica irregularis, subovalis; impressio muscularis pallii rectiuscula, longissima, posticè bifurcata. 

Plate XXV.
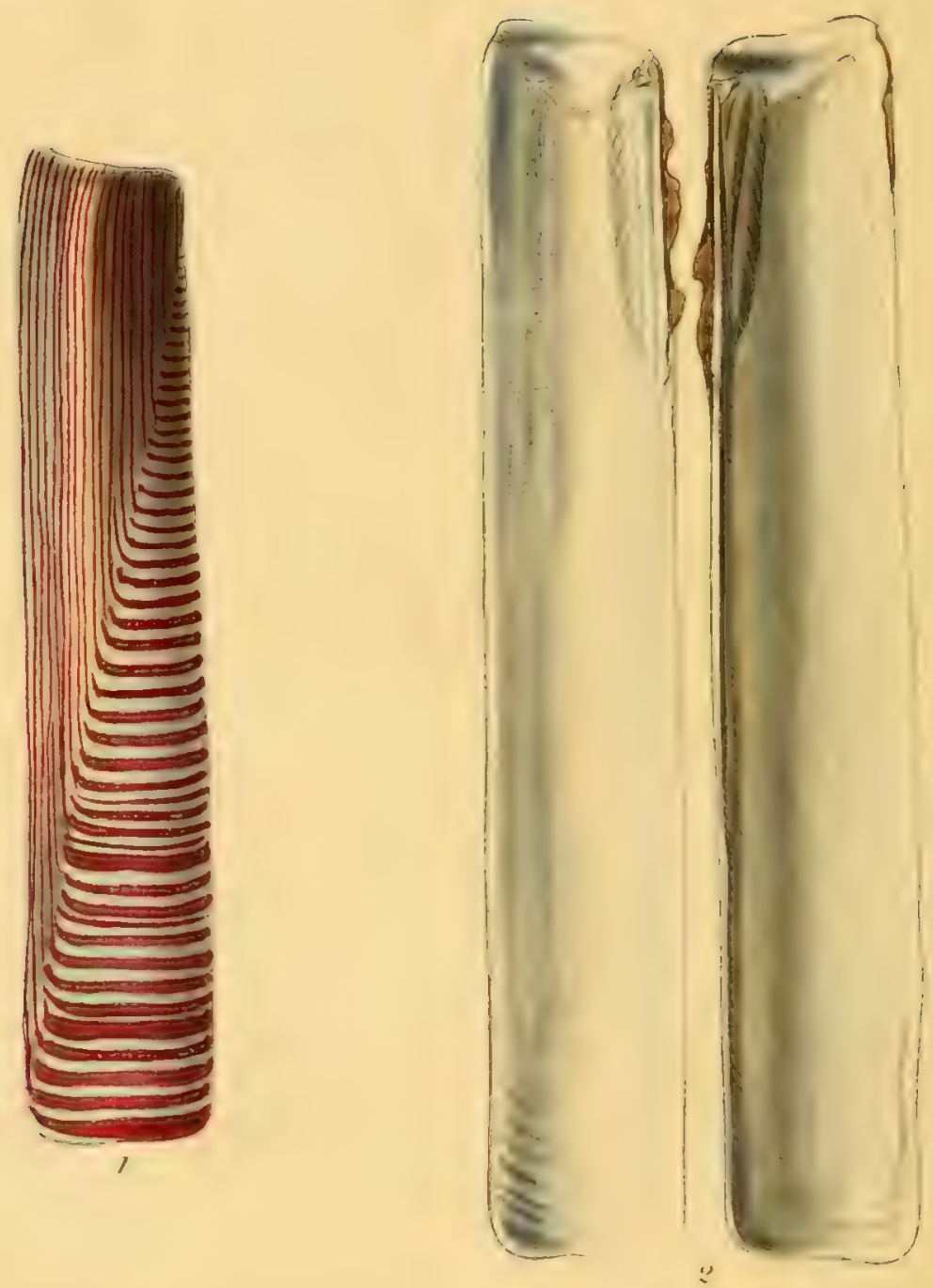

7. Solen trumentu.

$2 \quad$ Tequines. 
The genus Solen of Lamarck presents such a diversity of form and character, that we are induced to follow the plan proposed by Sowerby, of retaining in it only those species which have narrow, linear shells, with the umbones at one end, commonly called "Razor Shells." This arrangement allows us to remove several species, hitherto involving much confusion, to the Nymphacea, thus showing the propriety with which that family might have been placed immediately after the Solenucea. But in attempting this, so much difficulty arises in disposing of the Myaria and Mactracea, that we must be content to allow the Nymphacea to remain in the situation assigned to them by Lamarck.

The shell of the Solenes may therefore be described as equivalve, linear, subcylindrical, very inequilateral, and gaping at both ends, the anterior of which is somewhat truncated or rounded. The cardinal teeth are small and variable, the hinder one sometimes bifid, and generally recurved; there is also a lateral tooth in some species. The muscular impressions are clistant from each other: the anterior one is ligulate, placed under or behind the umbo; the posterior is irregular and nearly oval. The palleal impression is very long, and rather straight, divided at the posterior end into two branches.

The Solenes are found abundantly in all parts of the world, but especially on our own coast; they, however, vary so little, that the difference of locality is scarcely discoverable from the appearance of their shells.

\section{Examples.}

\section{Pl. XXV. Fig. 1.}

Solen truncatus, Sowerby, Genera of Shells, No. 32.

\section{Pl. XXV. Fig. 2.}

Solen vagina, Linnæus, Syst. Nat., p. 1113. Lamarck, Anim. sans vert., new edit., vol. vi.p. 53. Enc. Méth., pl. 222. f. 1. De Blainville, Manuel de Malacologie, pl. 79. f. 2. 


\section{SOLECURTUS, De Blainville.}

Testa æquivalvis, ovato-oblonga, transversa, utroque latere hians, interdum striis undulatis obliquè et longitudinaliter tecta. Cardo dentibus plerumque duobus in valvis ambabus, non intersertis. Impressio muscularis pallii profundè imbuta.

The genus Solecurtus of De Blainville is one which we gladly adopt in the distribution of Lamarck's Solenes, as it includes certain natural and characteristic species that are neither referable to the genus Solen, nor to any of the genera of the Nymphacea.

Its shell may be described as equivalve, ovately-oblong, transverse, gaping at both ends, and having the external surface sometimes covered with fine undulated strix, crossing the valves obliquely and longitudinally. There are two cardinal teeth in one valve, and one, rarely two, in the other, but not interlocking as in the Solenes. The muscular impression of the mantle is deeply marked.

\section{Examples.}

Pl. XXVI. Fig. 1.

Solecurtus Dombeit.

Solen Dombeii, Lamarck, Anim. sans vert., new edit,, vol. vi. p. 58. Enc. Méth., pl. 224. f. 1. $a, b, c$.

Novaculina (Dombeii?), Benson.

\section{Pl. XXVI. Fig. 2.}

Solecurtus acutidens.

Solen acutidens, Broderip and Sowerby, Zoological Journal, No. 15. p. 361.

Novaculina (acutidens?), Benson. 
SOLECURTUS.

Plate XXYY.
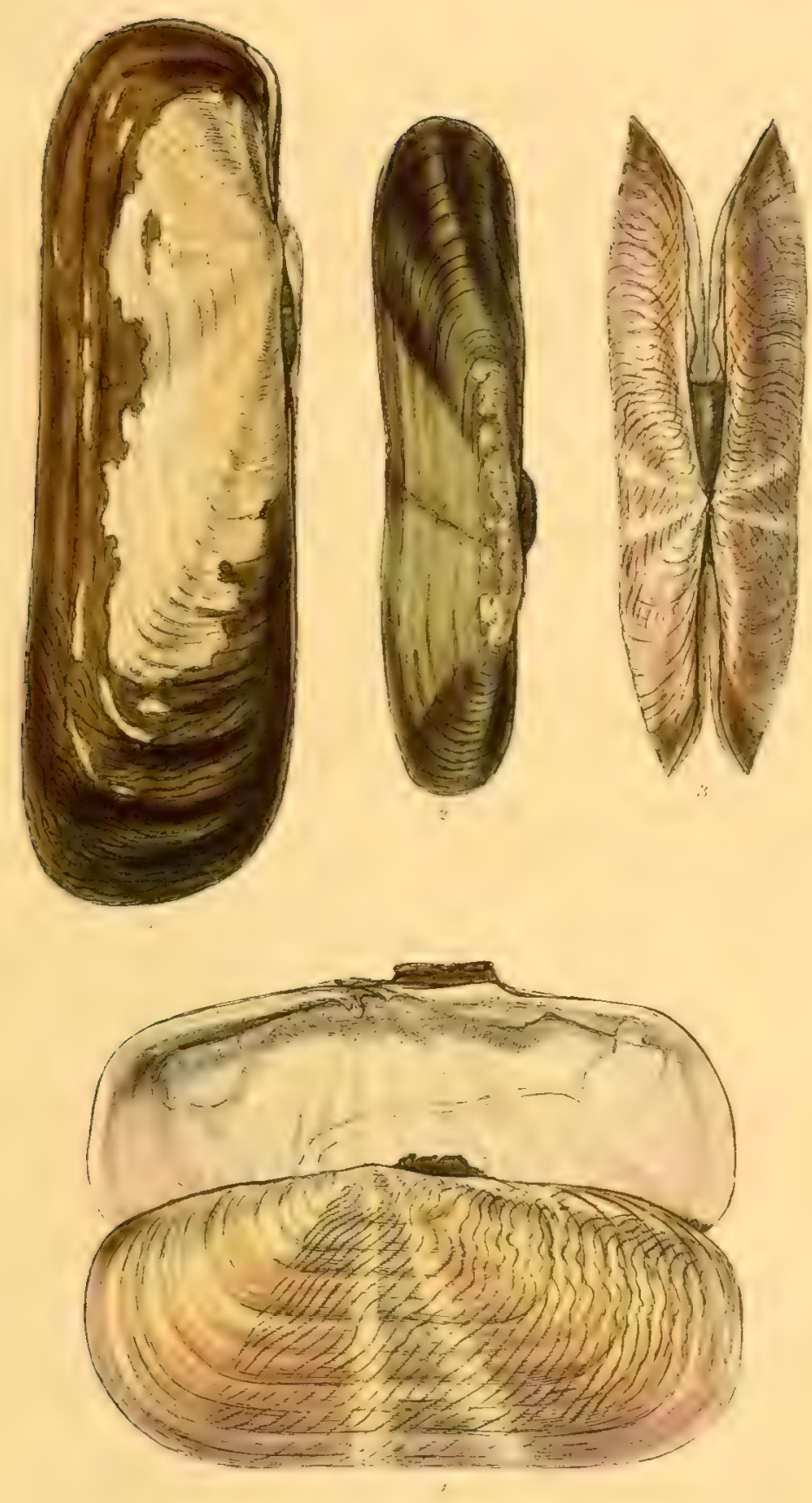


P.NOP.F.I

Plate XIYI.

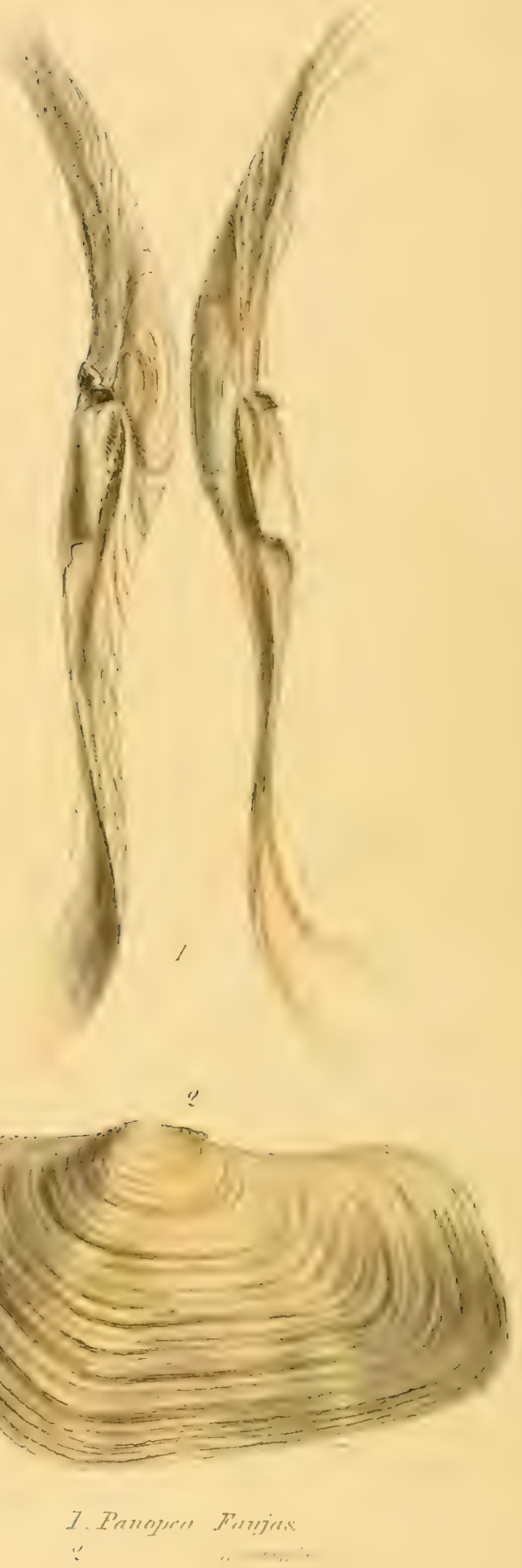


Pl. XXVI. Fig. 3 and 4.

Solecurtus strigilatus, De Blainville, Manuel de Malacologie, pl. 79.

f. 4. Enc. Méth., pl. 224. f. 3.

Solen strigilatus, Linnæus.

Idem, Lamarck.

\section{$P A N O P A A$, Ménard.}

Testa ovalis, aequivalvis, inæequilateralis, lateribus utrinque hians. Dens cardinalis in utrâque valvâ unicus, acutus. Ligamentum externum, fulcro maximo. Impressiones musculares dure, distantes; inpressio palli sinu maximo.

The shell of Panoprea, which is of large size, is closely allied to that of Solecurtus. It is described as oval, equivalve, inequilateral, and gaping widely at both ends; there is a single acute cardinal tooth in each valve, and the ligament is external, attached to a large fulcrum; the muscular points of attachment are distant from each other, and the palleal impression exhibits a large sinus.

\section{Examples.}

PI. XXVII. Fig. 1.

Panopea Aldrovandi, Ménard, Ann. du Mus., vol. ix. p. 13]. De

Blainville, Manuel de Malacologie, pl. 80. f. 2.

Mya glycimeris, Linnæus.

Panopaa Faujasi (testa fossilis), Sowerby, Genera of Shells, No. 40.

Pl. XXVII. Fig. 2.

Panopea australis, Sowerby, Genera of Shells, No. 40.

Panopea reflexa, Say? 


\section{GLYCIMERIS, Lamarck.}

Testa æequivalvis, crassa, transversa, utroque latere latissimè hians; epidermide nigrâ induta, valvarum marginem superante. Cardo callosus, edentulus, ligamento magno, externo. Impressiones musculares distantes; impressio pallii profundè imbuta.

The genus Glycimeris was instituted by Lamarck; it had been previously associated with the $M y c e$, but upon detecting the affinity of its characters with those of some of the Solenacea, he referred it to this family; and the propriety of the removal has been since confirmed by the anatomical demonstration of the animal by M. Ardouin.

The shell of Glycimeris is equivalve, thick, transverse, gaping widely at both ends, and covered with a thick, black, horny cpidermis passing over the edge of each valve. The hinge is entirely destitute of teeth, and the interior of the shell is remarkable for the strong impression of the mantle. The ligament, as in all the Solenacea, is external; but in this genus the position of it is reversed, being placed on the short side of the shell above the umbones, which are generally much eroded.

\section{Example.}

Pl, XXVIII. Fig. 1 and 2.

Glycimeris siliqua, Lamarck, Anim. sans vert., new edit., vol.v. p. 69.

Mya siliqua, Chemnitz.

Mya picea, Wood.

SOLEMYA, Lamarck.

Testa xquivalvis, inæquilateralis, transversim oblonga, ad extremitates obtusa ; epidermide nitidâ induta, marginem superante ; umbonibus 
GLYCIMERIS.

Plate XXVIII.
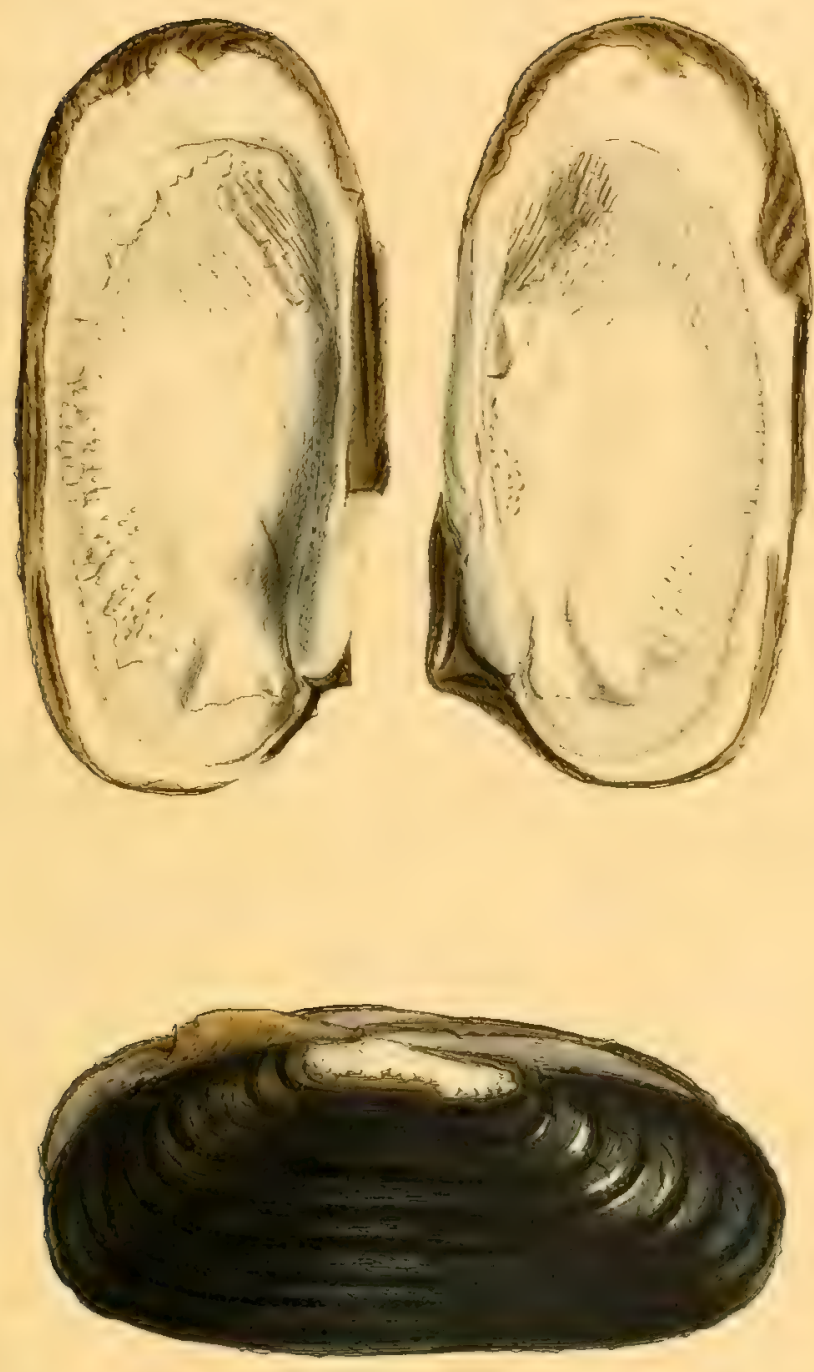

Glicimeris siliqua 


SOLEMYA.

Plate XX1X.
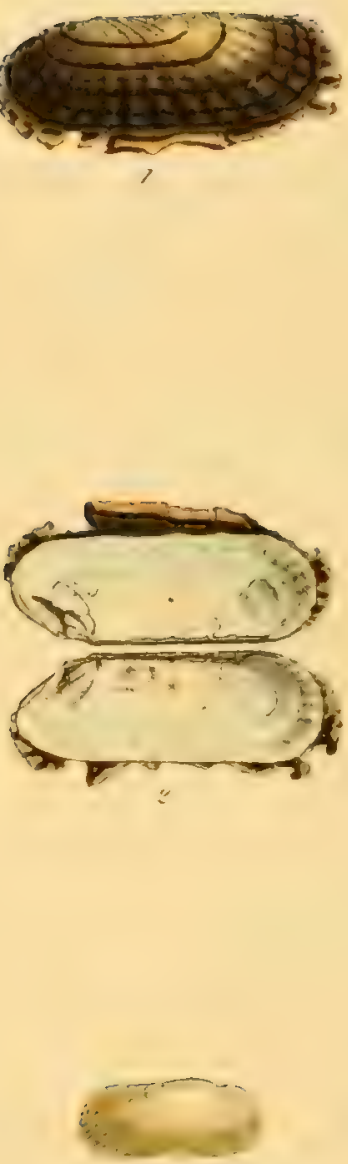

$\because$ 
non prominulis. Dens cardinalis in utrâque valvà unicus, dilatatus, compressus, perobliquus, supernè concavus, ligamentum excipiens. Ligamentum partim externum.

When Lamarck proposed the genus Solemya, he assigned it, with some indecision, to the family of Muctracea; Deshayes, however, after a careful examination of the animal, pronounces it to belong to the Solenacea on account of its affinity with Gilycimeris, an opinion previously given out by Sowerby.

The shell of Solemya is equivalve, inequilateral, transversely oblong, and obtuse at the extremities; it is covered with a shining brown epidermis, which passes over the edgres of the valves, and the umbones are not prominent. There is a cardinal tooth in each valve; and a callosity rumning between them receives the ligament, showing it both internally and externally.

\section{Examples.}

PI. XXIX. Fig. 1 and 2.

Solemya Mediterranea, Lamarck, Anim. sans vert., new edit, vol. vi. p. 124. Enc. Méth., pl. 225. f. 4.

Pl. XXIX. Fig. 3. (fossil.)

Solemya Parvula, Sowerby, Genera of Shells, No. 7.

\section{SOLENELLA, Sowerby.}

Testa ovalis, æquivalvis, subæquilateralis, compressa, nitens ; epidermidte olivaceo-viridi tenui induta; dentibus cardinalibus nullis; lateralibus anticis in utrâque valvâ tribus ad quatuor; lateralibus posticis plurimis, seriem rectiusculam efformantibus, omnibus parvis, acutis ; impressionibus muscularibus subdistantibus ; impressione pallii sinu magno; ligamento externo elongato. 
The genus Solenella was created by Sowerby for the introduction of a new and interesting molluscum brought from Valparaiso by Mr. Cuming. - Its shell may be said to partake of the characters of those of Solecurtus and Nucula, having an external ligament and large sinus in the muscular impression, as in the shell of the former; and a lateral row of sharp-pointed teeth, as in that of the latter, though chiefly on the posterior side.

He describes it as follows: "Shell longitudinally oval, equivalve, nearly equilateral, compressed, shining, covered with a thin olive-green epidermis; it has no cardinal teeth, and in each valve only three or four anterior lateral teeth; the posterior lateral teeth, however, are numerous, and form a nearly rectilinear scries; they are, moreover, small and sharppointed, those of one valve exactly fitting between those of the other; this series of small teeth is placed immediately below the fulcrum, to which the external elongated ligament is attached. The muscular impressions are two, lateral and rather distant, and there is a large sinus in that of the mantle."

\section{Example.}

Pl. XXX. Fig. 1 to 4.

Solenelia Norrisis, Sowerby, Genern of Shells, No. 39. Sowerby, Proceedings Zool. Soc., 1832, p. 197.

Ctenoconcha (Norrisii?), Gray.

\section{GLAUCONONE, Gray.}

Testa oblongo-ovalis, tenuis, ventricosa, aequivalvis, inæquilateralis, anticè rotundata, posticè subacuminata ; cpidermide viridi tenui corneâ induta; dentibus in utrâque valvâ tribus, posticis majoribus, valvæe dextralis medio, sinistralis postico, bifidis. Impressiones musculares duæ in utrâque valvâ, antica marginalis oblonga, postica subquadrata. Impressio muscularis pallii sinu magno, anticè obtuso. Ligamentum externum, oblongum. 




$$
\dot{\infty}
$$


This is a new genus of Solenacea introduced by Gray, and first described by him in his 'Spicilegia Zoologica.' The animal having been since received in spirits, a description was handed to Sowerby for insertion in his ' Genera of Shells.'

The shell of Glauconome is there described as "oblong-oval, thin, rather ventricose, equivalve, inequilateral; margins close; anterior end rounded, posterior somewhat acuminated; covered with a green, thin, horny epidermis, which is inflected over the margin all round; hingeteeth in each valve three, the posterior larger, the middle tooth of the right valve and posterior of the left bifid; no lateral teeth; muscular impressions two in each valve, the anterior marginal, oblong, the posterior subquadrate; palleal impression with a large, broad and deep, oblong sinus, obtuse at the anterior extremity ; ligament external, oblong."

\section{Example.}

PI. XXXI. Fig. 1 and 2.

Glauconome Chinensis, Gray, Spicilegia Zoologica, p.6. pl. 3. f. 13. 13 a. Sowerby, Genera of Shells, No. 42.

PHOLADOMYA, Sowerby.

Testa tenuis, subhyalina, transversa, ventricosa; posticè brevis, rotundata; anticè paululùm elongata, hians, supernè hiantula. Cardo foveolâ elongato-subtrigonâ, et laminâ marginali, quasi fulcro, in utrâque valvâ. Ligamentum externum, breviusculum, ad laminam externè affixum. Impressiones musculares duæ, indistinctæ. Sinus impressionis musculi adhærentis pallii magnus. Umbones approximati.

This remarkable genus, of which little is at present known, was instituted by Sowerby, and is said to partake of the characters of the PholaVOL. I. 
daria and Myaria; we cannot but think, however, that it has a stronger affinity with the Snlenacea, and have therefore arranged it accordingly.

Only one or two specimens of this curious molluscum are at present known, and as we have not had the opportunity of seeing the shell in good preservation, with the ligament entire, we give the original description of Sowerby: "Shell very thin, rather hyaline, transverse, ventricose, inside pearly ; posterior side short, sometimes rery short, rounded; anterior side more or less elongated, gaping; upper edge also gaping a little. Hinge with a small, rather elongated, triangular pit, and a marginal lamina in each valre, to the outer part of which is attached the rather short external ligament. Muscular mpressions two; these, as well as the muscular impression of the mantle, in which there is a large sinus, are indistinct."

\section{Example.}

PI. XXXII. Fig. 1 to 4.

Pholadomya candida, Sowerby, Genera of Shells, No. 19. Deshayes, Enc. Méth., vol. iii. p. 756.

\section{Family 4. MYARIA.}

Testa ad utrumque latus plerumque hians, ligamento interno, in cavo dentis prominuli, cochleariformi, inserto; rarò externo, appendice testaceâ interdum partim connexo.

The family of the Myaria form a very natural link between the solentcea and the Nactraceu, partaking of the characters of both. Their shell is generally gaping on hoth sides, with the ligament internal, inserted in the hollow of a prominent spoon-shaped tooth in one or both valves. It is, howerer, sometimes external, partially covered with a small testaceous appendage.

Lamarck includes but two genera in his family of Myaria, viz. Iya and Anatina, the latter of which we have found it necessary to divide, by 
PHOI ADOMYA.

Plate XXXII.

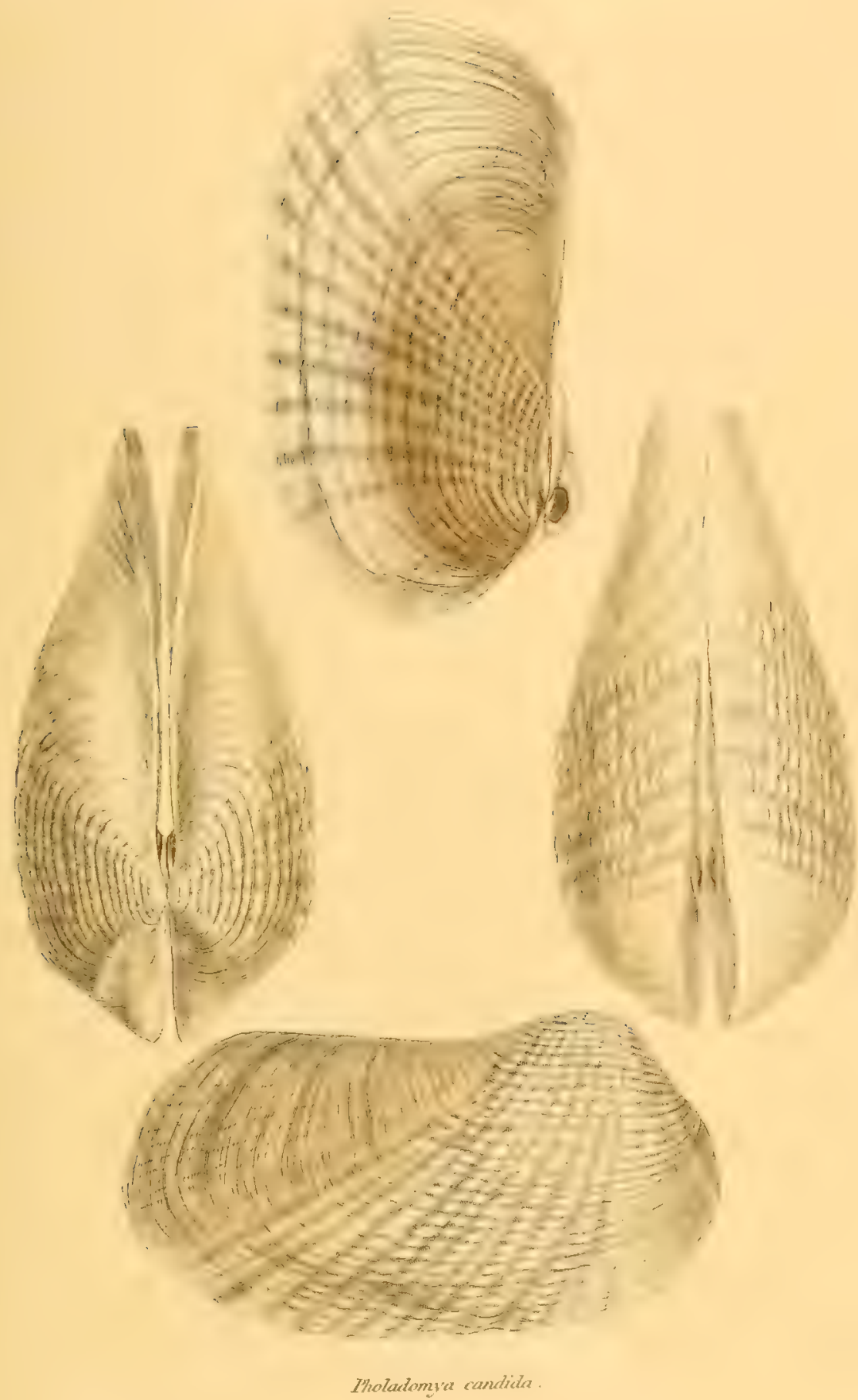




MYA.

Plate XXXIII.
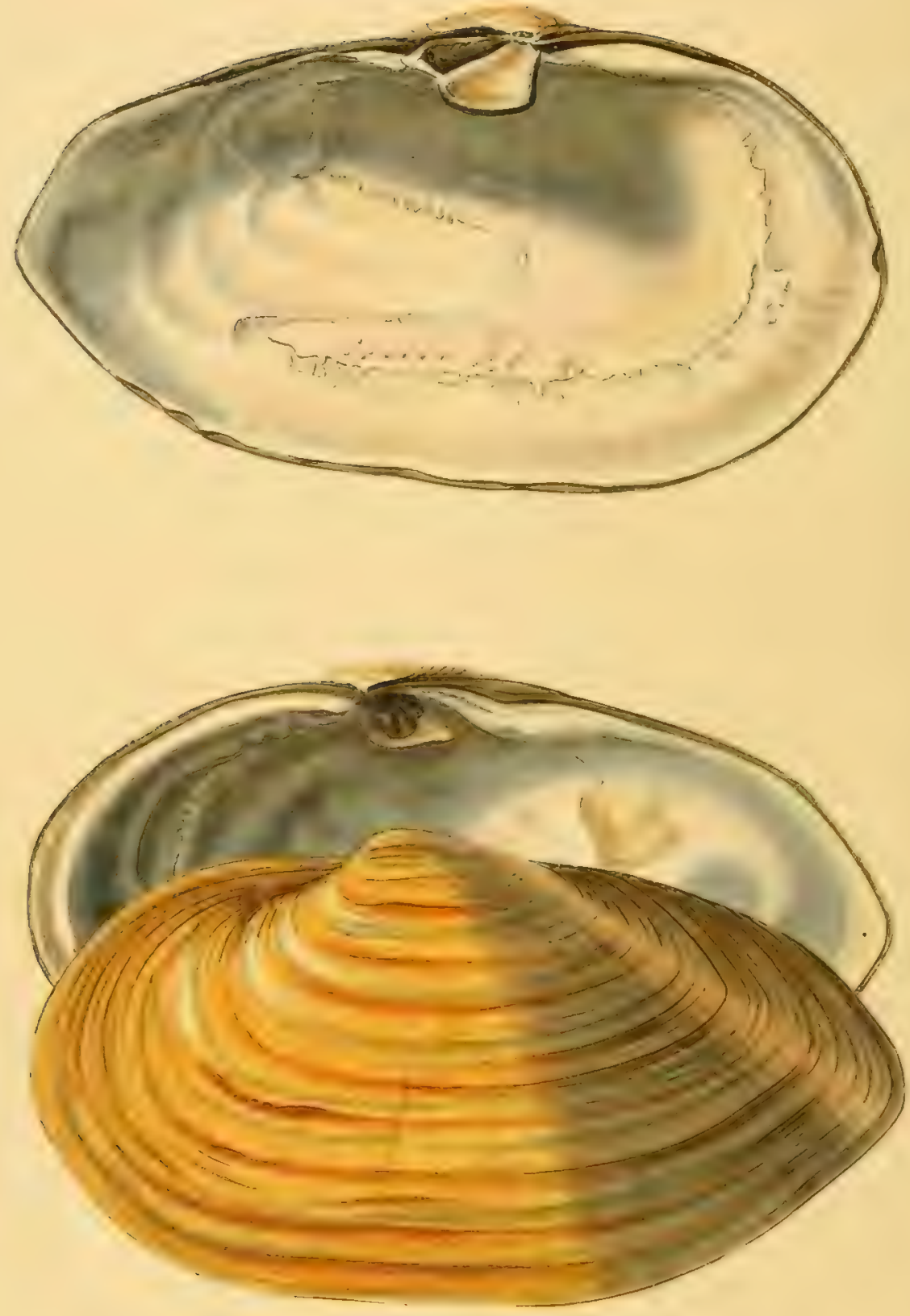

Alve atentarin 
adopting the genus Thrucia. We also include his family of Corbulacea with the Myaria ; and, in addition to these, are happy to have the opportunity of introducing three new and interesting genera from later writers, making eight in all, as follows:
MYa.
Pandora.
Anatina.
Anatinella.
Thracia.
Myochama.
Corbula.
Cleidotherus.

\section{$M Y A$, Linnæus.}

Testa transversa, inæquilateralis, utroque latere hians. Dens cardinalis in valvâ alterâ unicus, magnus, cochleariformis, dilatato-compressus ; fovea edentula in alterâ. Impressio muscularis pallii sinu magno. Ligamentum internum, inter dentem foveamque insertum.

The genus Mya, which serves to comnect this family with the Solenacea, though not very numerous in species, is peculiarly characterized. Its shell is transverse, inequilateral, gaping at both ends, and covered with a thick epidermis, which is continued at the anterior extremity over two lobes, protruded by the animal in making its way in the sand. There is a large, prominent, spoon-shaped tooth in one valve, with a corresponding pit or cavity in the other, between which the ligament or cartilage is inserted. The muscular impression of the mantle is very distinct, and exhibits a large sinus.

\section{Example.}

Pl. XXXIII. Fig. 1 and 2.

Mya arenaria, Linnæus, Syst. Nat., p. 1112 . Enc. Méth., vol. ii. p. 592. pl. 229. f. 1 . 
ANATINA, Lamarck.

Testa transversa, inæequilateralis, plerumque inæquivalvis, utroque latere hians; plerumque processu parvo, cochleariformi, ligamentifero, in utrâque valvâ; appendice testaceâ curvâ, parvâ, interdum minimâ, ante processus, ligamento connexâ.

From this genus, as established by Lamarck, three others have been created, Periploma, Osteodesma and Thracia, the last of which we have considered it necessary to retain. The true Anatina resembles Mya in its habit of living buried in the sand; but the shell differs in having the spoon-shaped ligamentiferous process in both valves, approaching in this particular to the shell of Lutraria, a genus of Mactracee. Its chief peculiarity, however, is in the appearance of a small, curved, testaceous appendage, situated before the spoon-shaped processes, and connected with the ligament, serving to strengthen it.

\section{Examples.}

PI. XXXIV. Fig. 1.

Anatina truncata, Lamarck, Anim. sans vert., new edit, vol. vi. p. 77. Enc. Méth., vol. ii. p. 39.

PI. XXXIV. Fig. 2.

Anatina Norvegica, Sowerby, Genera of Shells, No. 33. Amphidesma corbuloides, Lamarck. Osteodesma corbuloides, Deshayes. Mya Norvegica, Chemnitz. 
ANATINA

Plate XXXIV.
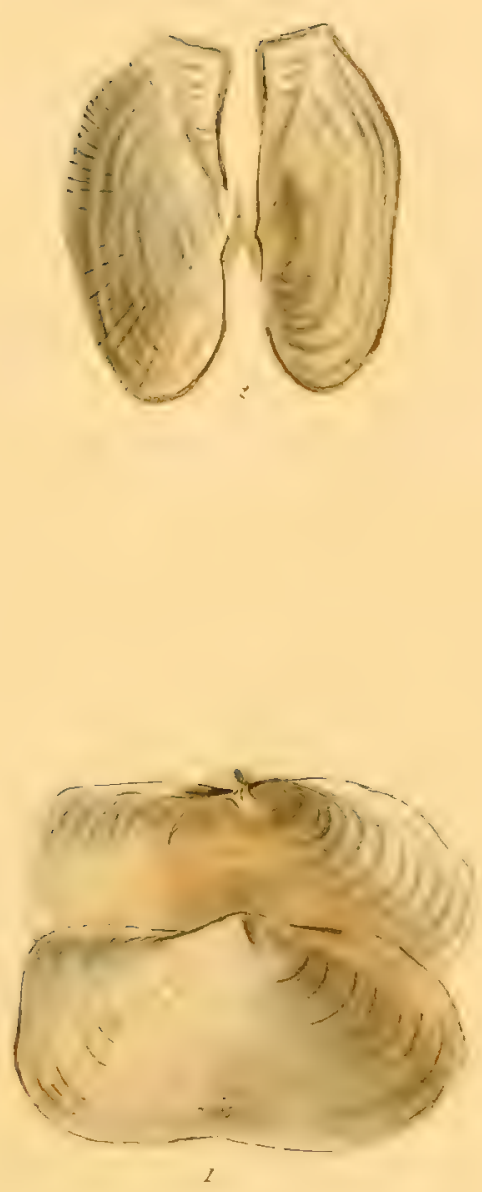

Fig.1. Anatina burecata

$r+\cdots, \cdot n$ 


THRACIA.

Plate XXIV.
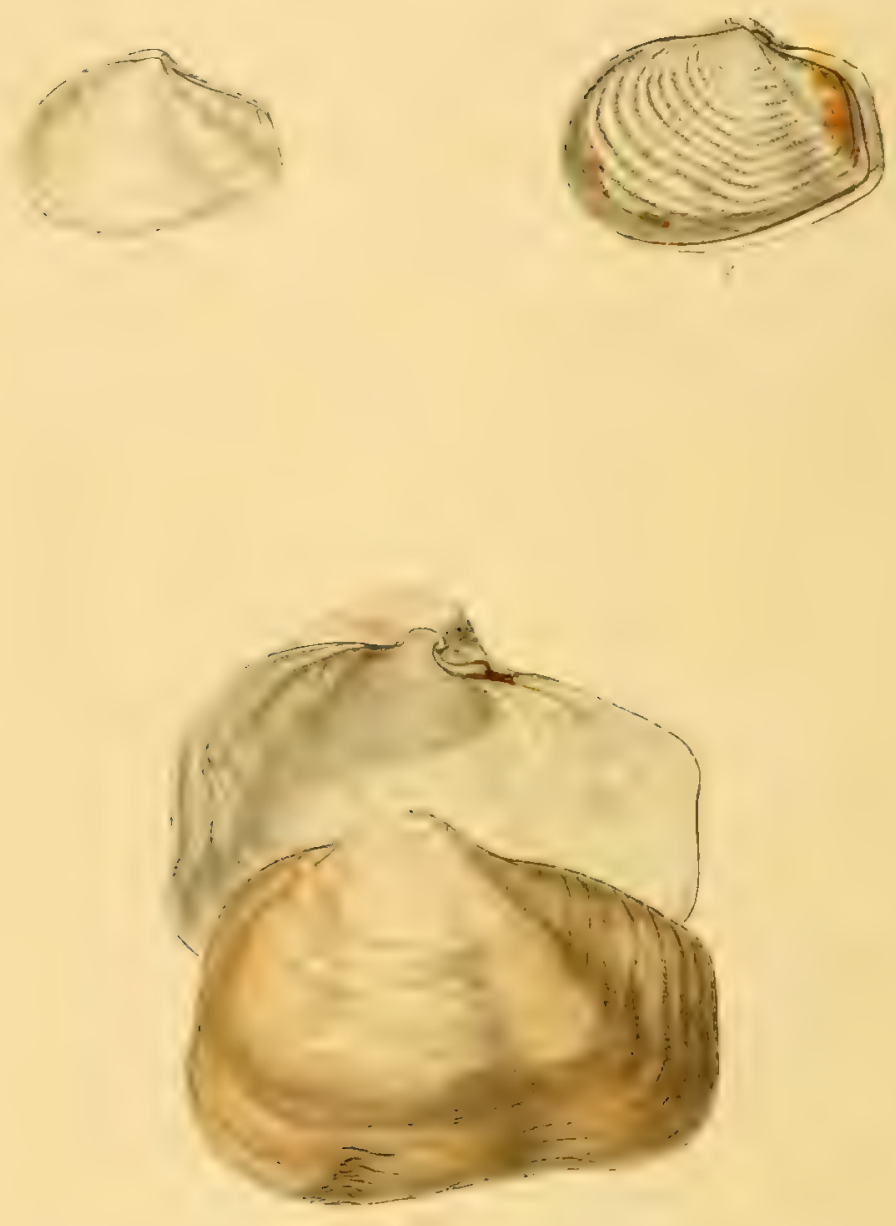
THRACIA, Leach.

Testa ovalis, oblonga, subæquilateralis, inæquivalvis, utroque latere paululı̀m hians. Cardo dente in utrique valvâ plus minusve prominulo, horizontali, cochleariformi, ligamentum excipiente. Impressio muscularis pallii profundè imbuta.

By adopting the genus Thracia of Dr. Leach, we are enabled to associate a very natural and distinct group of Myaria, that Lamarck had included with his Anatine.

Their shell is oval, oblong, and inequivalve; it is also thin, fragile, and gaping at both sides. The hinge consists of a more or less prominent, horizontal, spoon-shaped tooth in each valve, receiving the ligament; and the palleal impression is deeply marked.

\section{Examples.}

Pl. XXXV. Fig. 1.

Thracia phaseolina, Kiener, Iconographie des Coquilles vivantes, pl. "2. f. 4 .

Amphidesma phaseolina, Lamarck.

Pl. XXXV. Fig. 2.

Thracia Plicata, Deshayes, Enc. Méth., vol. iii. p. 1039. Kiener, Iconographie des Coquilles vivantes, pl. 2. f. 3.

Pl. XXXV. Fig. 3.

Thracia corfuloides, Deshayes, Dict. Classe d'Hist. Nat., vol. xvi. f. 4. De Blainville, Manuel de Malacologie, pl. 76. f. 7. 


\section{CORBULA, Bruguière.}

Testa inæquivalvis, subglobosa, brevis, crassa, utroque latere clausa. Dens cardinalis in utrấque valvá conicus, curvus, cochleariformis, ascendens, cum foveolâ laterali adjectâ, ligamento inserto. Impressio muscularis pallii sinu parvo.

To avoid unnecessary divisions, we have, in accordance with the opinion of Deshayes, included the genera Corbula and Pandora in the family of the Myaria. The distinction which Lamarck cites as peculiar to his family of Corbulacea, which is made up of these two genera, is, that their shells are inequivalve and irregular, characters which are common to many families of Bimuscular Tropiopoda.

The shell of Corbula may be described as inequivalve, subglobose, short, thick, and closed at the sides. In each valve, one of which is often considerably larger than the other, is an elevated, conical, recurved, spoon-shaped tooth, with a deep pit on one side of it for the insertion of the ligament. The muscular impression of the mantle exhibits a small sinus.

\section{Examples.}

Pl. XXXVI. Fig. 1.

Corbula nucleus, Lamarck, Anim. sans vert., new edit., vol.v. p. 139. Enc. Méth., pl, 230. f. 4.

Mya incquivalvis, Montague.

Pl. XXXVI. Fig. 2 and 3. (fossil).

Corbula Galitca, Lamarck, Anim. sans vert., new edit., vol.v. p. 140. Enc. Méth., pl. 230. f. 5. 
CORIBLLA.

Pate idisil.
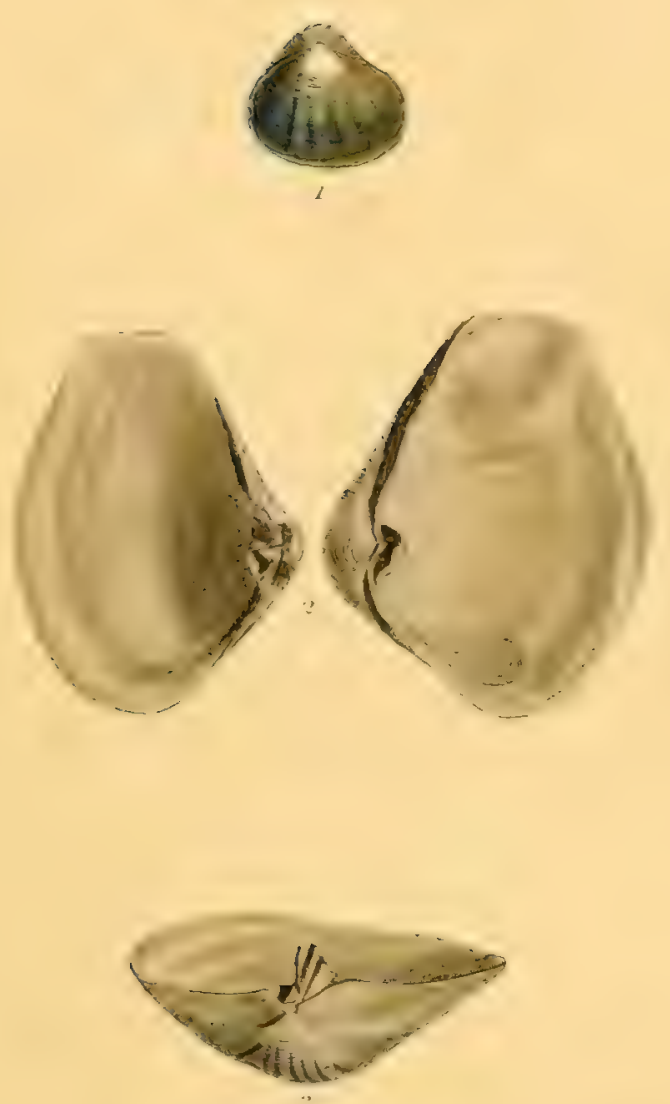

1. Cortudar studesus

2.3. Corbula gullica. 


PANDORA.

Plate XXXVII.
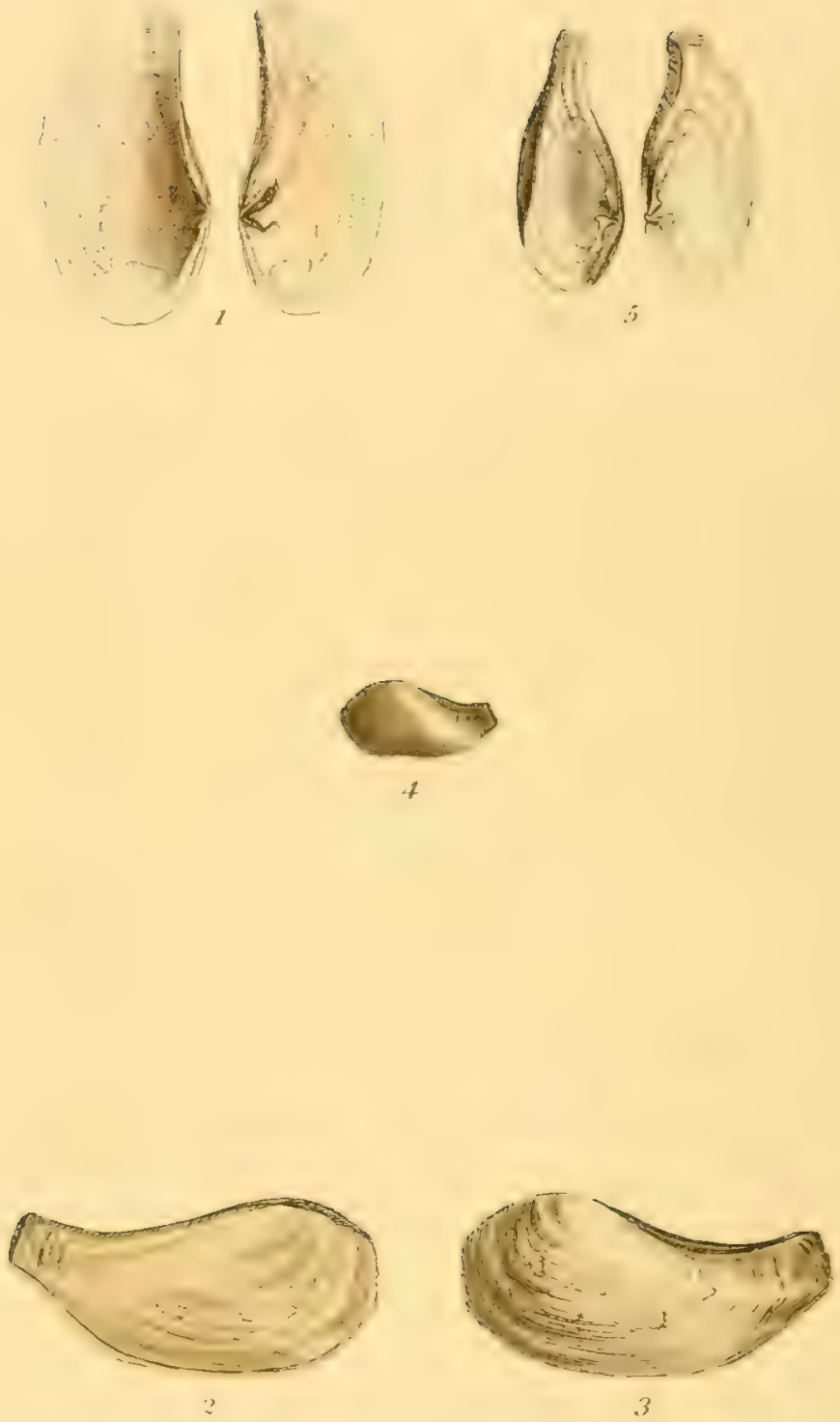

Fig. 1.2.3. Pandorn rostrata 4.8.5. P. flexzinsa. 
PANDORA, Bruguière.

'l'esta inaquivalvis, inaquilateralis, latere postico rotundato, antico transversim oblongo, hiantulo; valvâ alterâ planâ, margine antico deHexo, dente unico oblongo, divaricato, obtuso ; alterâ concavâ, edentulâ. Ligamentum internum, cicatricula elongata in utrâque valvâ affixum.

The genus Pandora, though not very numerous in species, compre. hends a distinct and characteristic series, and may be easily recognised by a certain peculiarity of lorm in the oblong, Hexuous curve of the anterior side of the shell, as also by a small dividing tooth which appears in one valve only. It may be described as inequivalve, inequilateral, somewhat pearly, with the posterior side rounded, the anterior tiansrersely oblong and slightly gaping; one valve is flat, turned downwards at the anterior margin, and has a single, oblong, obtuse tooth; the other is concave and destitute of teeth.

The ligament is internal, fixed to an elongated cicatrix in each valve.

Examples.

Pl. XXXVII. Fig. 1 to 3.

Pandora rostrata, Lamarck, Anim. sans vert., new edit., vol.vi. p. 145.

Sowerby, Species Conchyliorum, pl. 2. f. 7 to $y$.

Tellina incquivalvis, Linnæus.

Pl. XXXVII. Fig. 4 and 5.

Pandora flexuosa, Sowerby, Species Conchyliorum, pl. 3 . f. 13 to 15. 


\section{ANATINELLA, Sowerby.}

Testa ovata, æequivalvis, subxquilateralis ; latere antico rotundato, postico subrostrato, subtruncato ; ligamento interno, processui cochleariformi in utrâque valvà affixo, appendice testaceâ nullâ ; dentibus duobus cardinalibus in utrâque valvî ante processum positis. Impressio muscularis pallii integra, sinu nullo.

This new and interesting genus, which was introduced by Sowerby under the above title, has a shell very similor in its general appearance to that of Anatina; there is, however, no testaceous appendage, and the sinus in the muscular impression is also wanting. The shell of Anatinella exhibits many characters in common with that of Crassatella; in fact, some authors have considered that this genus might have been placed with equal propriety in the family of Mactracea; the extreme tenuity, however, of the shell, when compared with the solid thickness of that of the last-named genus, sufficiently indicates that their animals are essentially different.

The shell of Anatinella is ovate, nearly equilateral, with the anterior side rounded, and the posterior somewhat beaked or truncated; the ligament is internal, inserted between two spoon-shaped processes, one in each valve, and on the anterior side of each are two cardinal teeth. The muscular impression of the mantle does not exhibit any sinus.

Example.

Pl. XXXVIII. Fig. 1 and 2.

Anatinella Sibbaldi, Sowerby, Genera of Shells, No. 40. 
ANATINEIIAA.

Plate XXXVIII.
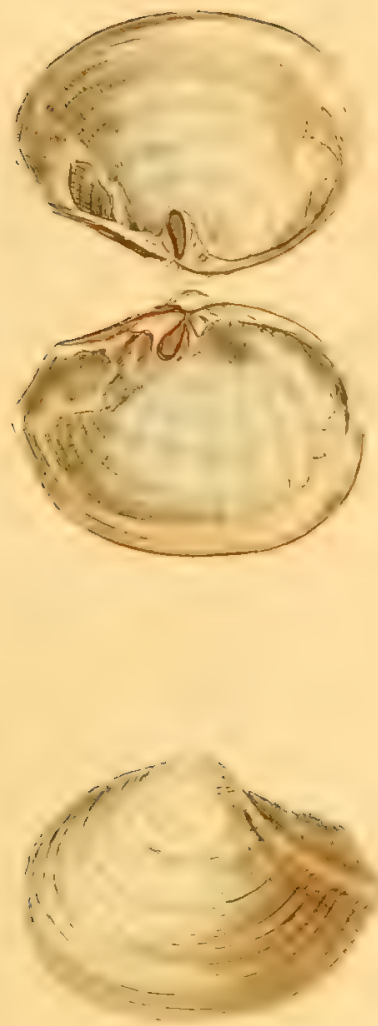


MYOCHAMA.

Plate XXXIX.
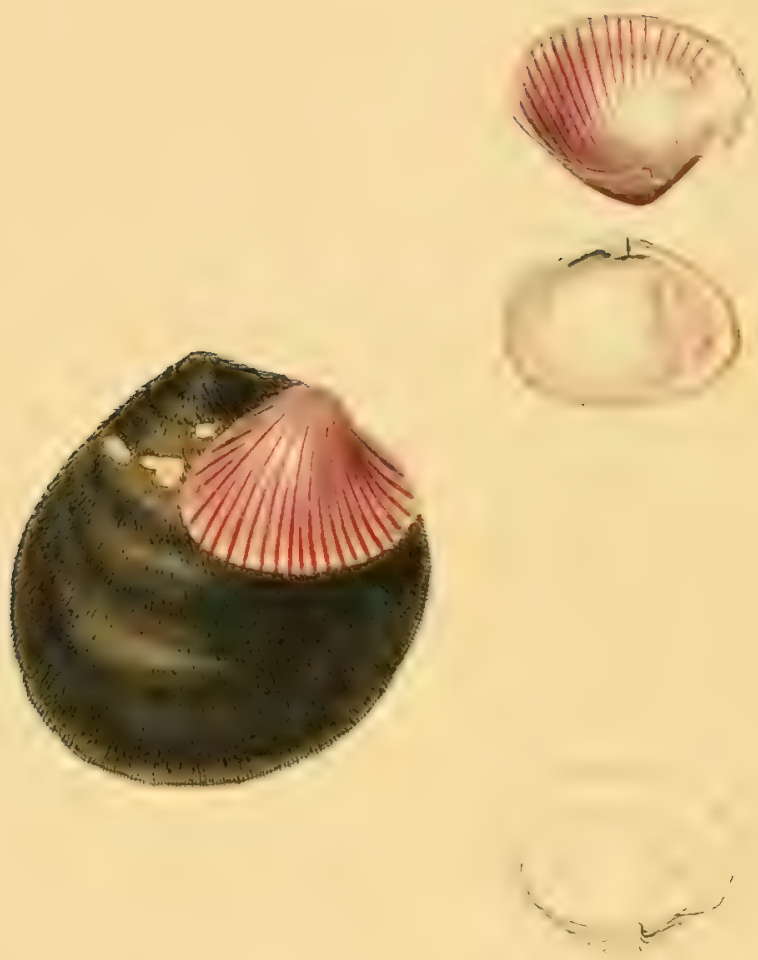

$\therefore-1=$

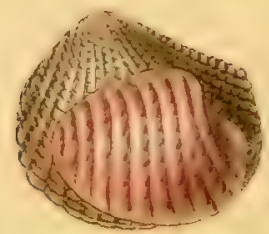

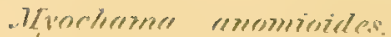


MYOCHAMA, Stutchbury.

Testa inæquivalvis, irregularis, adhærens, dentibus duobus cardinalibus divaricatis in utrâque valvà, foveâ trigonâ intermediâ cum appendice testaceâ minimâ, cartilagine connexî, insertî. Valva affixa plana, altera libera, convexa, costis vel sulcis interruptis, ab umbonibus ad marginem radiatis, tecta. Ligamentum tenue, externum. Impressio muscularis pallii sinu brevi, lato.

This remarkable genus, of which but few specimens have been seen, was introduced by Sowerby, and described by him as partaking of the characters of the Myaria and Chamacea. Its shell, like that of Anatina, is furnished with a testaceous appendage, and, as in that of Chama, the lower valve is immediately fixed to some marine body.

It may be described as inequivalve and irregular, with two diverging cardinal teeth in each valve, in the centre of which there is a triangular cavity, having a small testaceous appendage connected with it by a horny cartilage. One valve is attached and flat, the other is free and very convex, covered with ribs or interrupted grooves, radiating from the umbones to the margin. The ligament is thin and external. The palleal impression exhibits a short broad sinus.

Example.

Pl. XXXIX. Fig. 1 to 4.

Mrochama anomioides, Sowerby, Genera of Shells, No. 32. 


\section{CLEIDOTHRRUS, Stutchbury.}

Testa inæquivalvis, adhærens; valva affixa convexissima, valva libera plana; dente cardinali conico, in fossulam valvæ affixæ inserto, cum appendice testaceâ, elongatâ, recurvâ, ad cicatricem profundam infrà umbones cartilagine utrinque connexâ. Impressio muscularis pallii integra. Ligamentum externum.

The genus Cleidothrerus, described by Sowerby in his 'Genera,' offers another remarkable shell from the same locality as the former; and although differing considerably in general appearance, it will be found to approximate to that of Myochama, both in having the testaceous appendage, and in being always immediately fixed by the lower valve. Deshayes informs us that this shell is the Chama ulbida of Lamarck, and that the genus Cleidothrerus should be referred to the fanily of Chamacea ; there is, however, too clear an affinity in the clavicle or testaceous appendage to the genera Myochama and Anatina, to question the propriety of its arrangement with the Myaria.

We adopt the well-known title, Cleidotharus, of Stutchbury, as being that by which this genus is generally known. De Roissy, who was the first to notice a peculiarity in the general appearance of its shell, has a prior claim to the name of Chamostrea; but the discovery of the clavicle, which is the most important feature, is due to Stutchbury.

The shell of Cleidothærus is described as being inequivalve, and somewhat pearly in the interior; the attached valve is very convex, the other flat, having a small pointed tooth fitting into a corresponding pit in the former; and there is a long, recurved, testaceous appendage, called the clavicle, connected by a cartilage at both ends to a deep cicatrix under each umbo. The muscular impression of the mantle is entire, and the ligament is external. 

CLEIDOTH ERUS.

Plate XL.
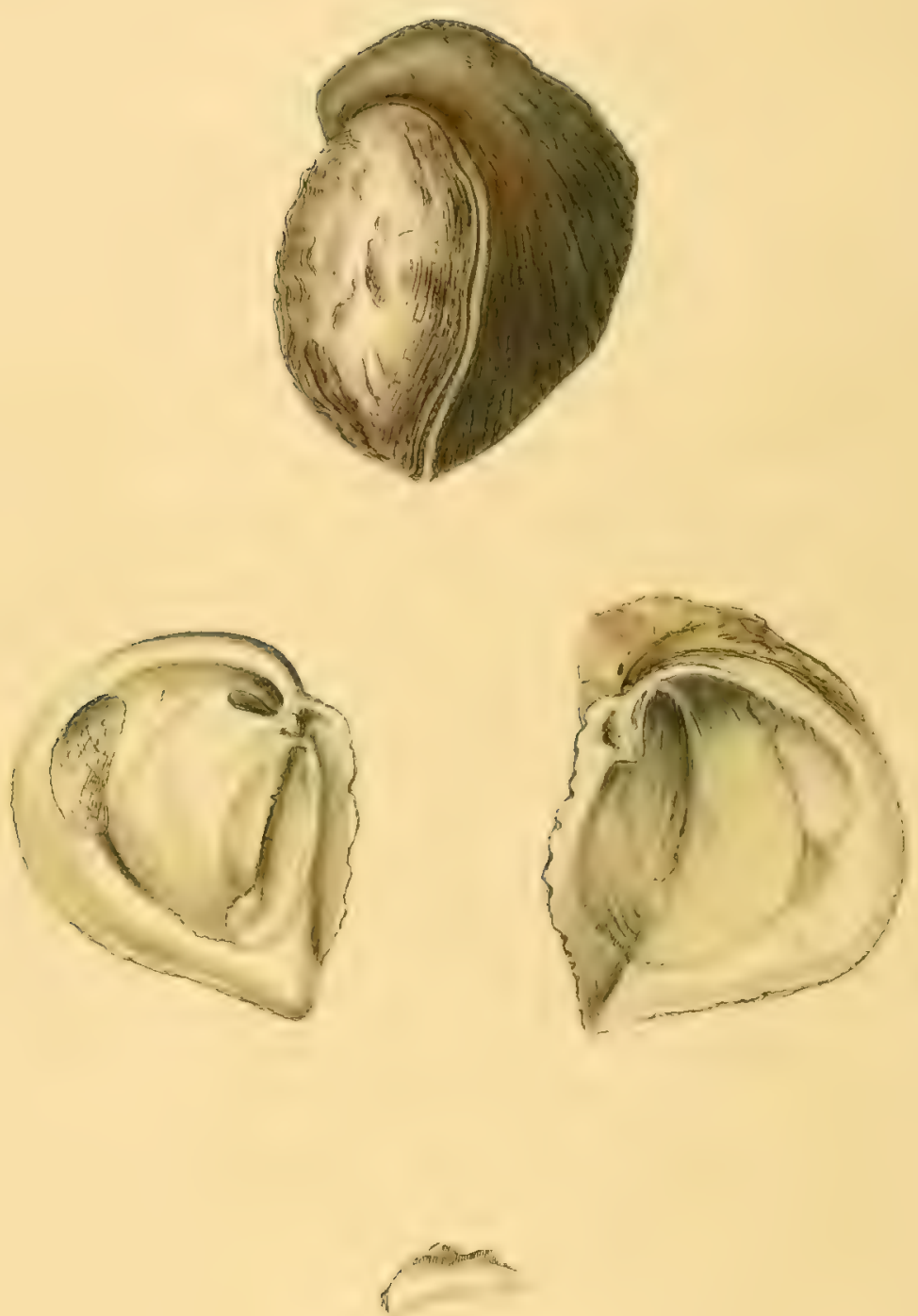


\section{Example. \\ Pl. XL. Fig. 1 to 4.}

Cleidotherus chamoides, Sowerby, Genera of Shells, No. 32.

Chama albida? Lamarck.

Cleidothcrus albidus, Deshayes.

Chamostrea (chamoides?), De Roissy. Gray.

\section{Family 5. MACTRACEA.}

Testa plerumque inæquilateralis, lateribus vel clausis vel hiantibus. Ligamentum partim vel omninò internum.

The Mactracea form a very distinct and well-defined family, though, from the peculiar modification of character in many of them, considerable confusion has arisen in the subdivision. The careful exposition of this family by Deshayes, in his notes to the new edition of Lamarck, has however added considerably to our knowledge; and we think that the adoption of his genus Mesodesma will materially assist the arrangement.

The Mactracea have generally an inequilateral shell, either closed or gaping, and the ligament is always partially or altogether internal. We include eight genera in this family, as follows :

Lutraria.

Mactra.

Gnathodon.

Crassatella.
Mesodesma.

UNGULINA.

Amphidesma.

Cumingia. 


\section{LUTRARIA, Lamarck.}

Testa æequivalvis, inæquilateralis, transversa, oblonga vel ovata, lateribus hians. Cardo dentibus alterius valvæ duobus; alterius tribus, quorum posticus tenuis, compressus. Dentes laterales nulli. Ligamentum internum, in foveis dentibus adjectis insertum. Impressio muscularis pallii sinu magno.

The shell of Lutraria differs materially from that of Mactra, with which genus the Lutraria were formerly united. It may be easily distinguished by the absence of lateral teeth; it has also a large sinus in the muscular impression, and may be described as being equivalve, inequilateral, transverse, oblong or ovate, and gaping at the sides. The hinge has two teeth in one valve and three in the other, the posterior one being thin and compressed. The ligament is internal, inserted in a pit near the teeth in each valve, and the palleal impression exhibits a large sinus.

\section{Examples.}

Pl. XLI. Fig. 1.

Lutraria solenoides, Lamarck, Anim. sans vert., new edit., vol. vi. p. 90.

Mya oblonga, Gmelin.

Mactra hians, Montague.

Lutricola solenoides, De Blainville.

PI. XLI. Fig. 2.

Lutraria papyracea, Lamarck, Anim. sans vert., new edit., vol. vi. p. 93.

Mactra papyracea, Gmelin. 


$$
30
$$




MACTRA.

Plate XLII.

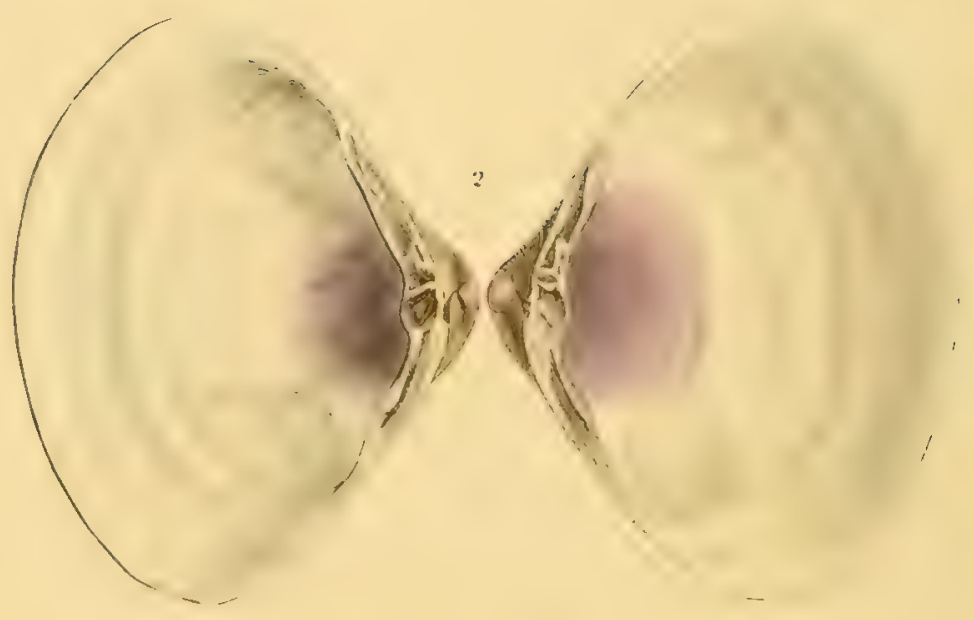

3
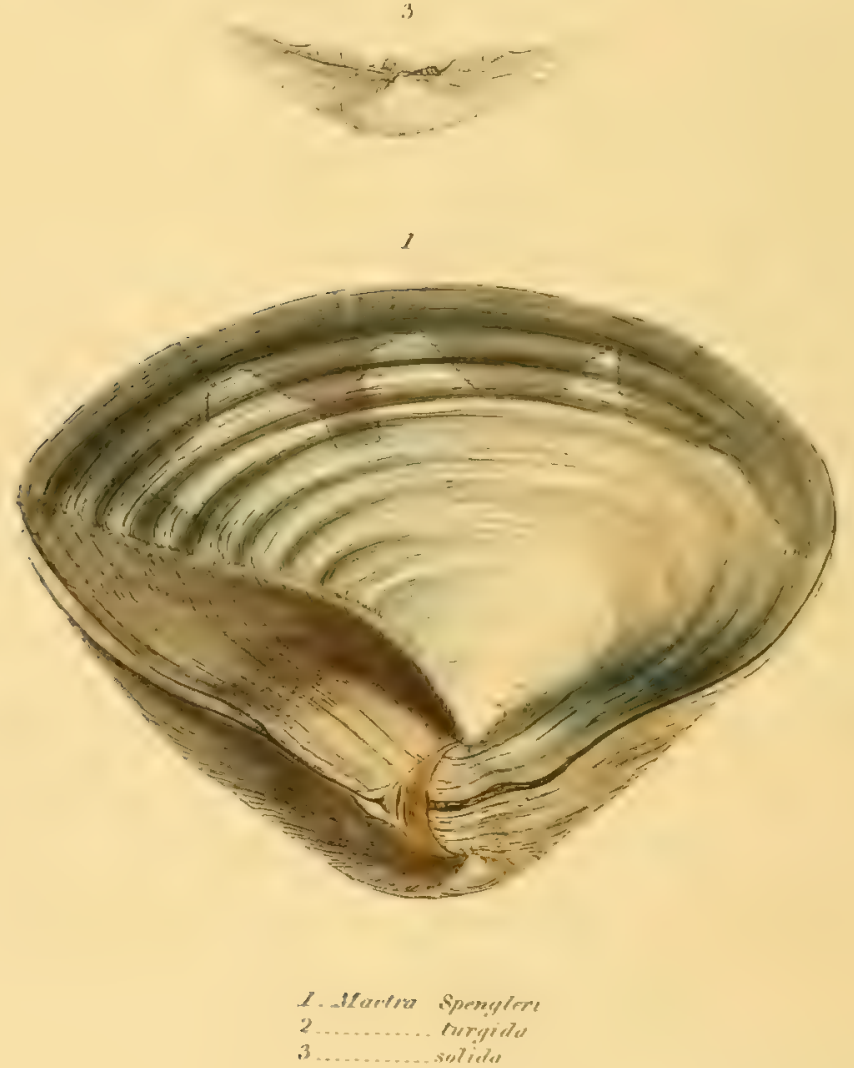


\section{MACTRA, Linnæus.}

Testa requivalvis, subrequilateralis, plerumque trigona, lateribus paululùm hians; dente cardinali trigono in utrâque valvâ, cum foveolâ adjectì; dentibus lateralibus in valvì alterà. duobus anticis, duobus posticis; in alterî, uno antico, uno postico. Ligamentum duplex, majus internum.

The Mactra are very numerous, and include many rare and beautiful species; their shells exhibit rather a diversity of form, but are generally more or less triangular.

They are described as being equivalve, nearly equilateral, and generally gaping a little at the sides. The hinge is characterized by a projecting triangular cardinal tooth in each valve, with sometimes another thin sharp one on the posterior side of it; there is also an elongated lateral tooth diverging from each side the umbo in one valve, fitting between two similarly situated in the opposite valve. The ligament is duplex, mostly internal, inserted in a deep pit between the sriangular cardinal teeth.

\section{Examples.}

PI. XLII. Fig. 1.

Mactra Spengleri, Gmelin, Syst. Nat., p. 3256. Lamarck, Anim. sam. vert., new edit., vol. vi. p. 97. Enc. Méth., pl. 25\%. f. 3.

Schizodesma Spengleri, Gray.

Pl. XLII. Fig. 2.

Mactra turgida, Gmelin, No. 17. Lamarck, Anim. sans vert, new edit., vol. vi. p. 102. Enc. Méth., pl. 255. f. 3.

Pl. XLII. Fig. 3.

Mactra solida, Linnæus, Syst. Nat., p. 1126. Lamarck, Anim. sans vert., new edit., vol. vi. p. 104. Enc. Méth., pl. 258. f. 1. 


\section{GNATHODON, Gray.}

Testa subovalis, æquivalvis, inæquilateralis ; epidermide olivaceâ induta, ad umbones plerumque paululùm decorticata; dentibus alterius valvie lateralibus duobus cum cardinali unico, alterius lateralibus et cardinalibus duobus, ligamento in foveolì interjacente. Impressio muscularis pallii sinu parvo.

The genus Gnathodon was created by Gray for the purpose of introducing a new variety of Mactraceu, with a shell resembling, in general appearance, that of some of the fluviatile Conchacea; the position of the ligament, however, sufticiently indicates the family to which it belongs.

The shell of Gnathodon is nearly oval, equivalve, inequilateral, and covered with an olive-green epidermis, generally a little decorticated at the umbones; it has a lateral and two cardinal teeth in one valve, shutting between two cardinal and two lateral teeth in the other. The ligament is internal, inserted in a deep pit situated between the cardinal and posterior lateral teeth, and the impression of the mantle exhibits a small sinus.

Example.

Pl. XLIII. Fig. 1 to 4.

Gnathodon cuneatus, Gray. American Journ. of Science. Sowerby, Genera of Shells, No. 36 .

\section{CRASSATELLA, Lamarck.}

Testa æquivalvis, transversa, inæquilateralis, undique clausa; epidermide fuscâ induta. Cardo in valvâ alterâ dentibus duobus; in alterâ dente unico; cum foveolâ in utrâque valvâ anticè adjectâ, 
GNATHODON.

Plate XLIII.-
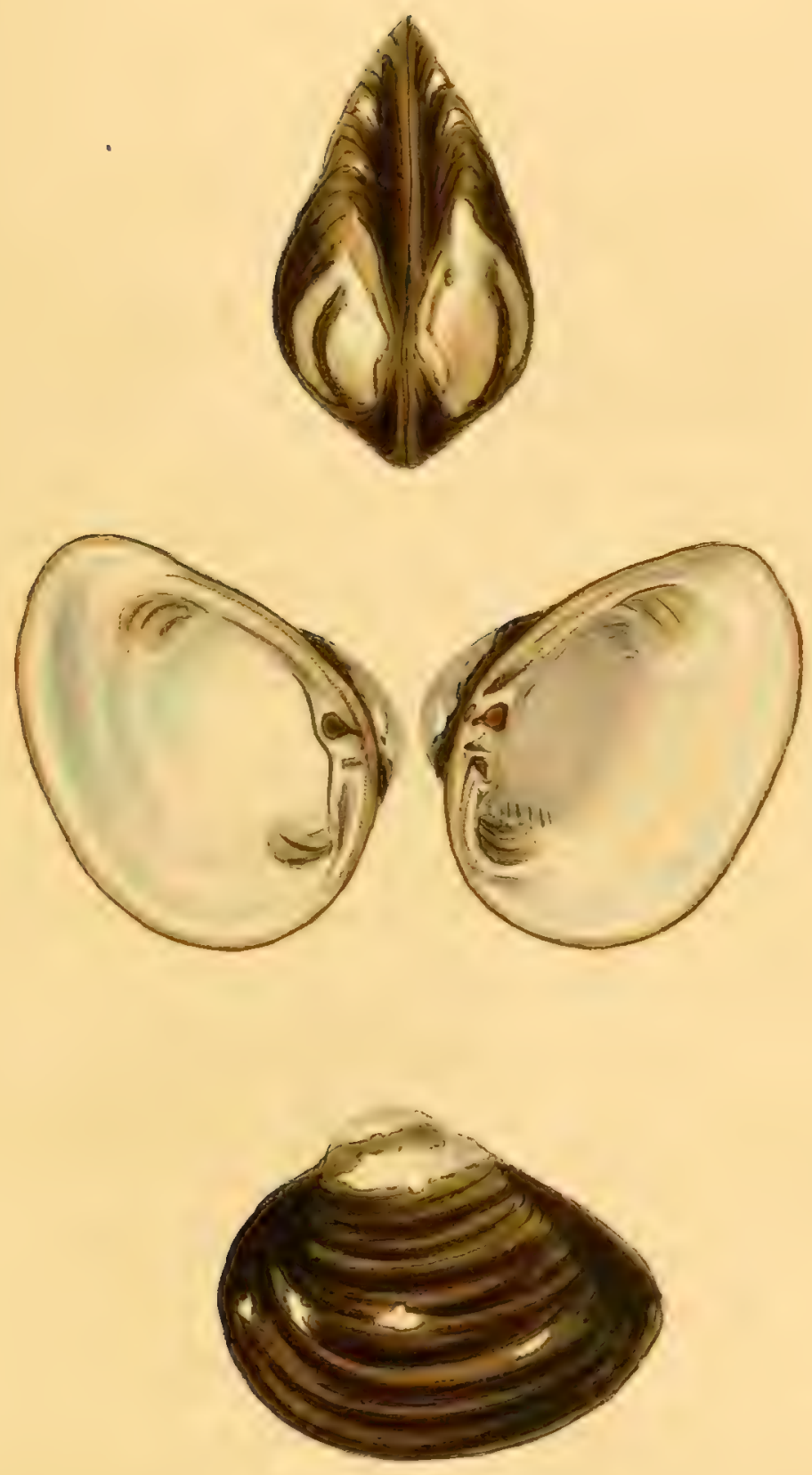


CRASSA'TELLA.

Plate XLIV.
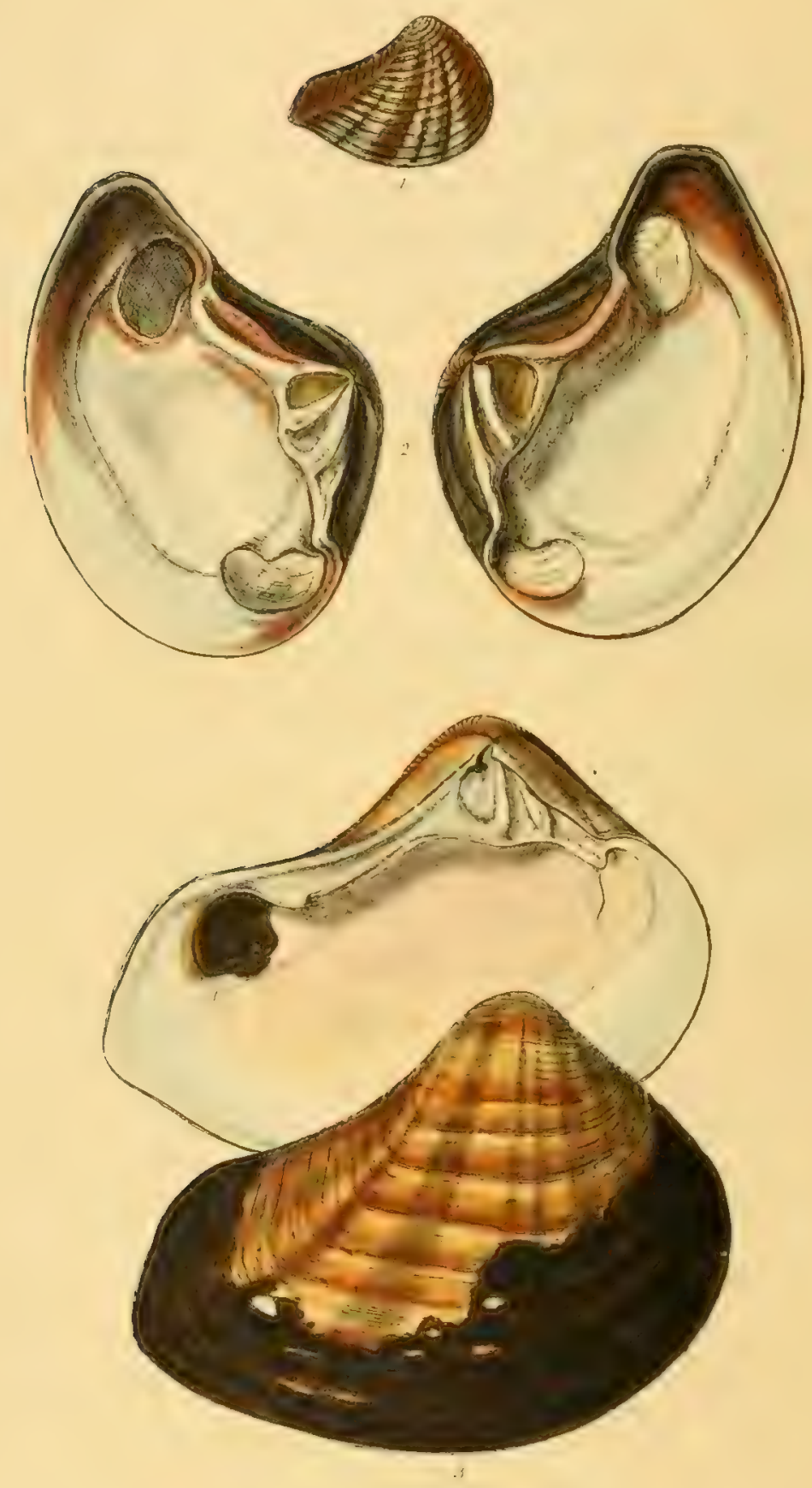
ligamento profundè inserto. Dentes laterales nulli, aut obsoleti. Impressiones musculares distinctissimè imbutæ.

The shell of Crassatella bears a certain resemblance to that of Lutraria, both in the position of the ligament, and in the absence of lateral teeth, but may be easily recognised by the thickness of the valves, and their rich dark brown epidermis.

It may be described as being equivalve, transverse, inequilateral, and everywhere closely shut. There are two cardinal teeth in one valve and one in the other, and at the anterior side of them is situated a deep pit for the reception of the ligament. There are no lateral teeth, or they are obsolete. The points of muscular attachment are very distinctly marked.

\section{Examples.}

Pl. XLIV. Fig. 1.

Crassatella radiata, Sowerby. Tankerville Catalogue, App., p. 2. f. 2 .

Pl. XLIV, Fig. 2.

Crassatella gibbosa, Sowerby, Proceedings Zool. Soc. 1832, p. 56.

Pl. XLIV. Fig. 3.

Crassatella Kingicola, Lamarck, Anim. sans vert., new edit, vol. vi. p. 109. Sowerby, Genera of Shells, No. 3.

\section{MESODESMA, Deshayes.}

Testa ovata, transversa vel subtriangularis, subcompressa, aquivalvis, crassa, plerumque clausa. Cardo dentibus lateralibus duobus, crassis, in utrâque valvâ ; cum foveolâ profundâ, cochleariformi, interjacente, ligamento inserto. Impressiones musculares inæequales, anteriori majori, elongatâ; impressio pallii sinu posteriori. 
The genus Mesodesma, which we gladly adopt, to facilitate the arrangement of the Mactracea, was instituted by Deshayes for the purpose of associating those species which are intermediate in their characters between the Crassatelle and the Amphidesmatu. They may certainly be said to approximate rather to the former, but are still clearly distinct; and the propriety of this genus has moreover been fully confirmed by a careful investigation of the animal, since made by M. Quoy.

It may be observed, on reference to our synonyma, that some of the Mesodesmata have been inadvertently taken by Sowerby as examples of Lamarck's genus Erycina, a genus, which the former, like most naturalists, was eridently at a loss to identify. Lamarck might well have pronounced his Erycince to be "des coquilles en quelque sorte équivoques," he, however, described but one recent species; and although Deshayes uncourteously notices in his 'Déscription des Coquilles Fossiles,' that Lamarck associated in his genus Erycinu "presque toutes: les petites coquilles dont on n'u pus bien rccomu le genre," he has not failed to acknowledge a second recent species, described by Payrandeau in his 'Catalogue des Mollusques de l'Ile de Corse.' Neither of them are we able to identify, and have therefore abandoned Lamarck's grenus Erycina altogether; still, whether it may be preserved with propriety as a fossil genus or not, it is not our province to determine.

The shell of Mesodesma may be described as being ovate, transverse or somewhat triangular, equivalve, rather compressed, thick and generally closed. The hinge has two thick lateral teeth in each valve, between which is situated a deep spoon-shaped cavity for the insertion of the ligainent. The muscular points of attachment are unequal, and the impression of the mantle exhibits a sinus on the posterior side.

Examples.

Pl. XLV. Fig. 1.

Mesodesma CiennitziI, Deshayes, Enc. Méth., vol. ii. p. 443. Quoy et Gaimard, Voy. de l'Astrolabe, pl.82. f. 9 to 11.

Mya Australis, Gmelin.

Mya Nova Zelandia, Chemnitz. 
MESODESMA

Plate XLV.
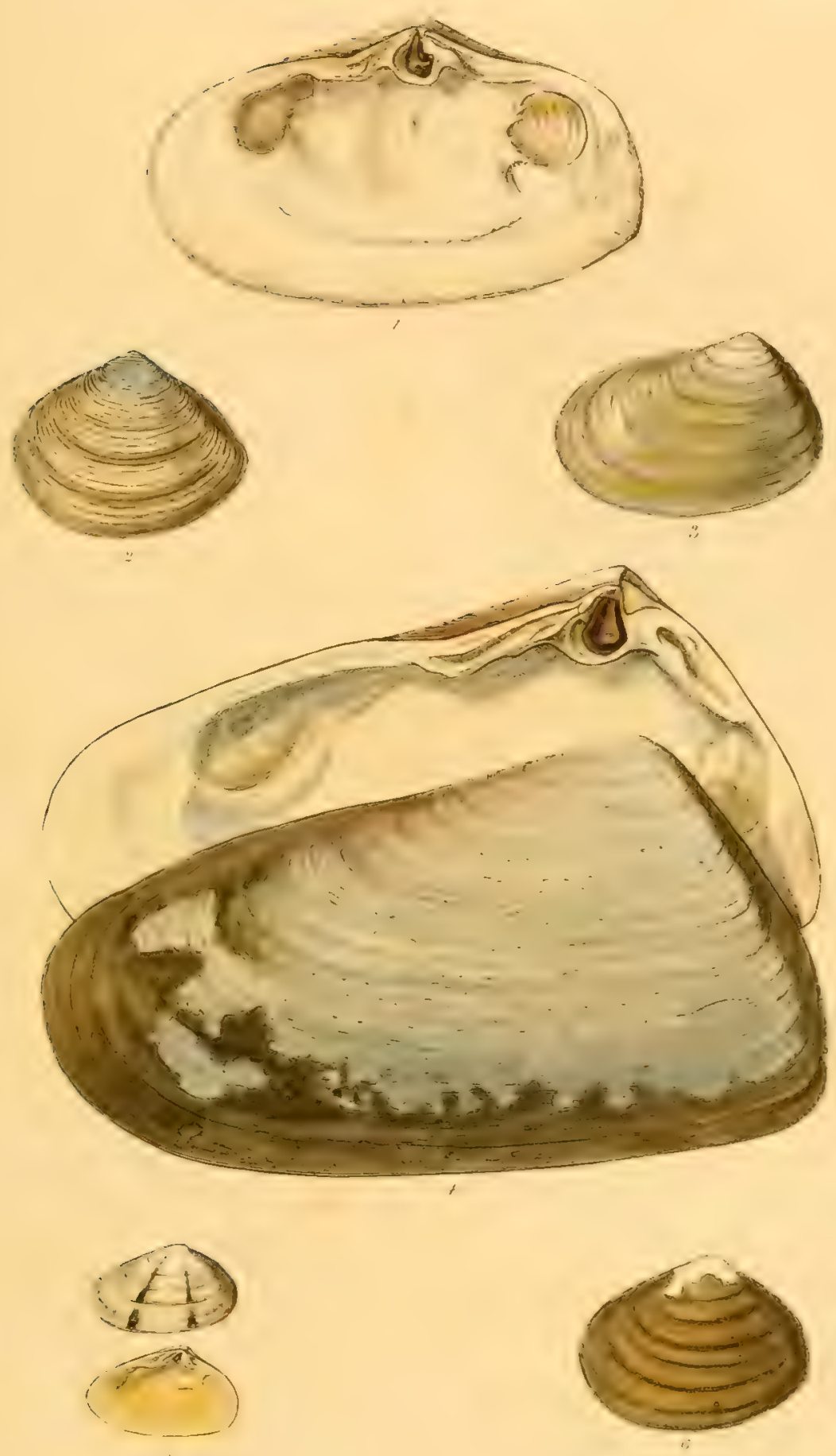



\section{Pl. XLV. Fig. 2.}

Mesodesma striatum, Deshayes, Enc. Méth., vol. ii. p. 443. Quoy et Gaimard, Voy. de l'Astrolabe, pl. 82. f. 15 to 17.

Mactra striata, Gmelin.

Crassatella striata, Lamarck.

Erycina striata, Sowerby.

\section{Pl. XLV. Fig. 3.}

Mesodesia a retatum, Gould, Invert. of Massachusetts, p. 57. f. 39.

Mactra urctata, Conrad.

Mactra subtriangulata, Wood.

\section{PI. XLV. Fig. 4.}

Mesodesma donacia, Deshayes, Enc. Méth., vol. ii. p. 442.

Mactra donacia, Lamarck.

\section{Pl. XLV. Fig. 5.}

Mesodesma nonacilda, Deshayes, Enc. Méth., vol. ii. p. 44 . Payrandeau, Cat. Moll. de Corse, p. 31.

Amphidesma donacilla, Lamarck.

Erycina plebeia, Sowerby.

Donax plebeia, Montague.

Crassatella cuneata? Lamarck.

\section{Pl. XLV. Fig. 6.}

Mrsodesia glabratum, Deshayes, Note in new edition of Lamarck, p. 133.

Crassatella polita, Lamarck.

Erycina complanata, Sowerby. 
UNGULINA, Daudin.

Testa suborbicularis, rotundata, aquivalvis, subrequilateralis, clausa. Cardo dente in alterâ valvâ brevi, subdiviso; dentibus in alterâ duobus, quorum unus minutissimus; cum forei adjectî, oblongî, marginali, medio angustato-divisit, ligamentum semi-internum recipiente. Dentes laterales nulli. Impressio muscularis pallii integra, distinctè imbuta.

The genus Ungulina was instituted by Daudin for the reception of a remarkable variety of Mactracea, differing in a peculiar derree from any of the family, particularly in the position of the ligament.

Its shell is nearly orbicular, rounded, equivalve, suberpuilateral, and closed at the sides. There is a short, bifid, cardinal tooth in each valve, with the addition of a very small one in one valve only, but no lateral teeth; and just within the anterior margin, there is an oblong, narrowly divided pit or carity containing the ligument, which is also divided, and so near the margin as to be partially visible externally. The muscular impression of the mantle is entire and distinctly marked.

\section{Example. \\ Pl. XLVI. Fig. 1 to 3.}

Ungulina transversa, Lamarck, Anim. sans vert, new edit, vol. vi. p. 122.

Ungulina oblonga, var., Deshayes.

\section{AMPHIDESMA, Lamarck.}

Testa subinæeruilateralis, transversa, subovalis vel rotundata, lateribus interdum subhians. Cardo aut dente unico, aut dentibus duobus in 
UNGULINA.

Plate XLVI.
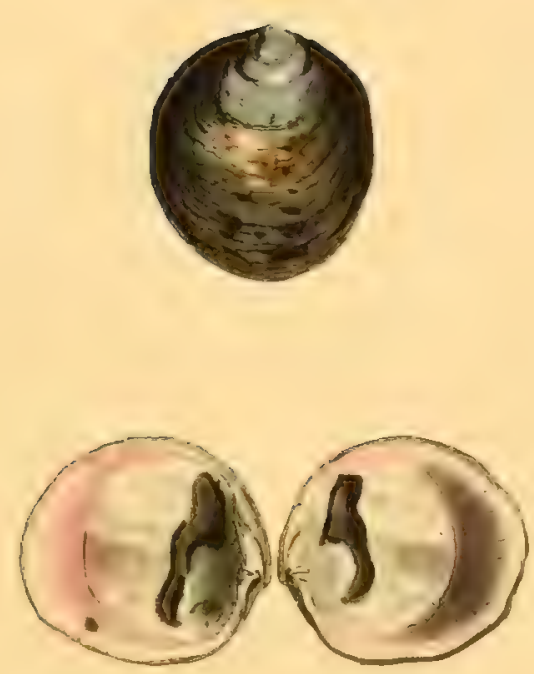

M 


AMPHIDESMA.

Plate XLVII.

Inphidesmiat
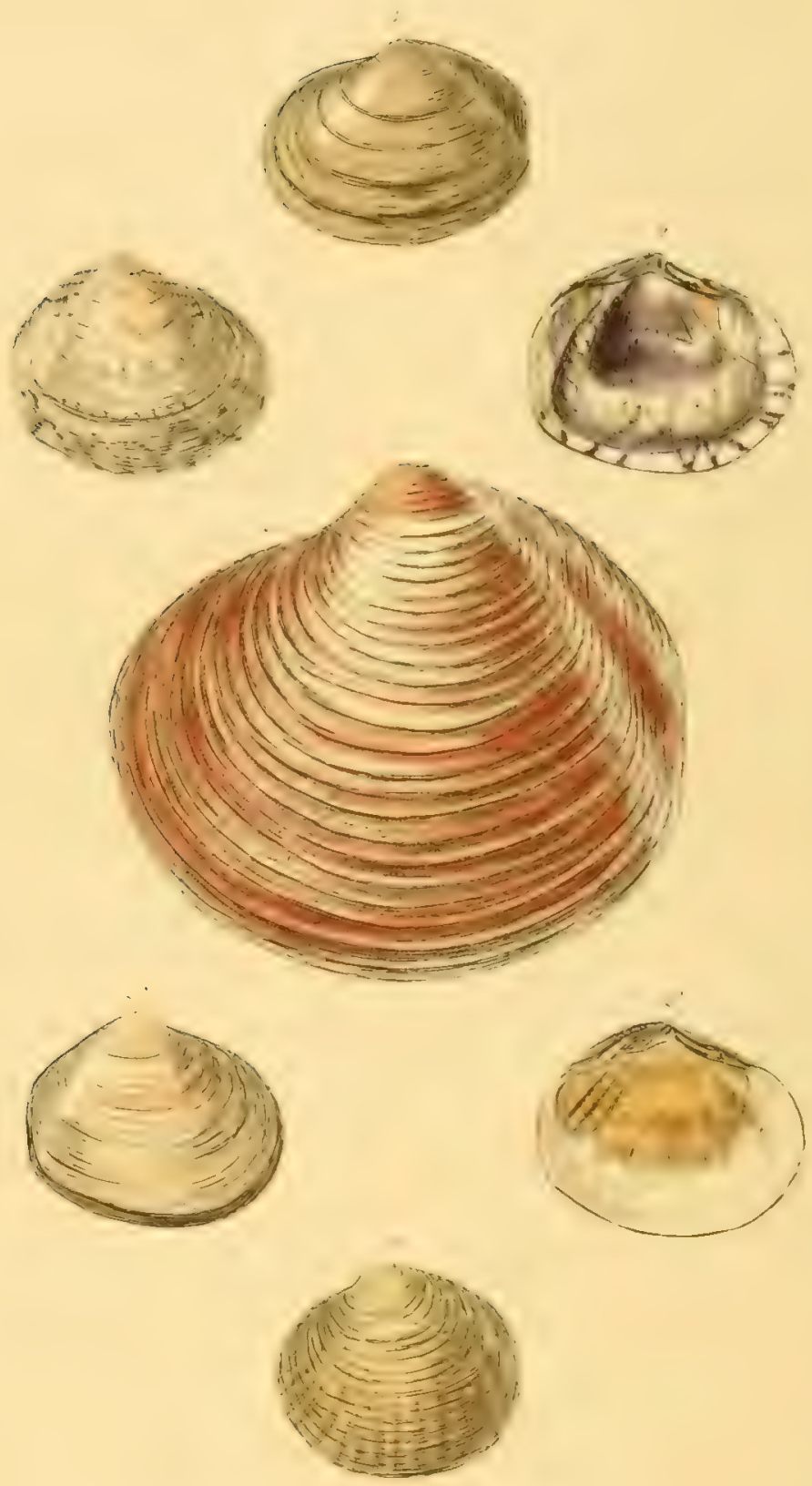
utrîque ralvấ cum foreolì angustî elongatâ interjacente. Ligamentum duplex, partim tenue et externum, partìm breve et internum, in foveolis cardinalibus insertum. Impressio muscularis pallii sinu magno.

The genus Amphidesma includes a numerous and well-defined group of Mactracea : their shells are somewhat variable in form, some being transverse, others orbicular, but are nevertheless readily distinguished by the peculiar position of the ligament, which is duplex. There was at first much confusion in the formation of this genus by Lamarck; but by the removal of some of his Amphidesmata to the Mesodesmata, we are enabled to retain a very natural and interesting series. Many new species too have been added since his time, contributing much to the importance of the genus.

The shell of Amphidesma may be described as being somewhat inequilateral, transverse, nearly oval or round, and slightly gaping at the sides. The hinge is composed of either one or two cardinal teeth in each valve, with a long narrow pit lying between them for the insertion of the ligament, which is duplex, partly external and thin, partly internal and short. The palleal impression has a large sinus.

\section{Examples.}

PI. XLVII. Fig. 1.

Amphidesma roseum, Sowerby, Proceedings Zool. Soc., 1832, p. 199.

Pl. XLVII. Fig. 2 and 2*.

Ampindesina pulchrum, Sowerby, Proceedings Zool. Soc., 1832, p. 57.

Pl. XLVII. Fig. 3.

Aypuidesma Pallidum, Sowerby, Proceedings Zool. Soc., 1832, p. 199.

Pl. XLVII. Fig. 4.

Ampindesma australe, Sowerby, Proceedings Zool. Soc., 1832, p. 200. 
PI. XLVIII. Fig. 5.

Ampindesma purpurascens, Sowerby, Proceedings Zool. Soc., 1832, p. 199.

\author{
Pl. XLVIII. Fig. 6.
}

Amphidesma leve, Sowerby, Proceedings Zool. Soc., 1832, p. 200.

\title{
Pl. XLVIII. Fig. 7 .
}

Ampindesma formosun, Sowerby, Proceedings Zool. Soc., 1832, p. 199.

\section{CUMINGIA, Sowerby.}

Testa inæquilateralis, xquivalvis, latere antico rotundato, postico subacuminato; dentibus, cardinali in utrâque valvâ unico, parvo, antico, lateralibus in alterâ valvâ ad utrumque latus uno, valido, in alterî nullo. Ligamentum internum, foveolix cochleariformi athixo. Impressiones musculares distinctè imbuta, anticá irregulari, posticâ subrotundatâ; impressio muscularis pallii sinu maximo.

This genus was established by Sowerby fur the introduction of a series of new and interesting species of Mactracea, brought to England by Mr. Cuming. Their shell exhibits the musual character of having two strong lateral teeth in one valve and none in the other, but approximates in other respects to that of the Amphidesmata.

Mr. Sowerby describes the shell of Cumingia as being "inequilateral, equivalve, with the anterior side rounded and the posterior rather acuminated. A single small anterior cardinal tooth is observable in each valve; and there is one strong lateral tooth on each side of the hinge in one valve, but no lateral tooth in the other; the ligament is internal, and affixed to a somewhat spoon-shaped pit in each valve. The anterior muscular impression is irregular and oblong, the posterior rounded, and there is a very large sinus in the muscular impression of the mantle." 
AMPHIDESMA.

Plate XLVIII.

Amohidesma
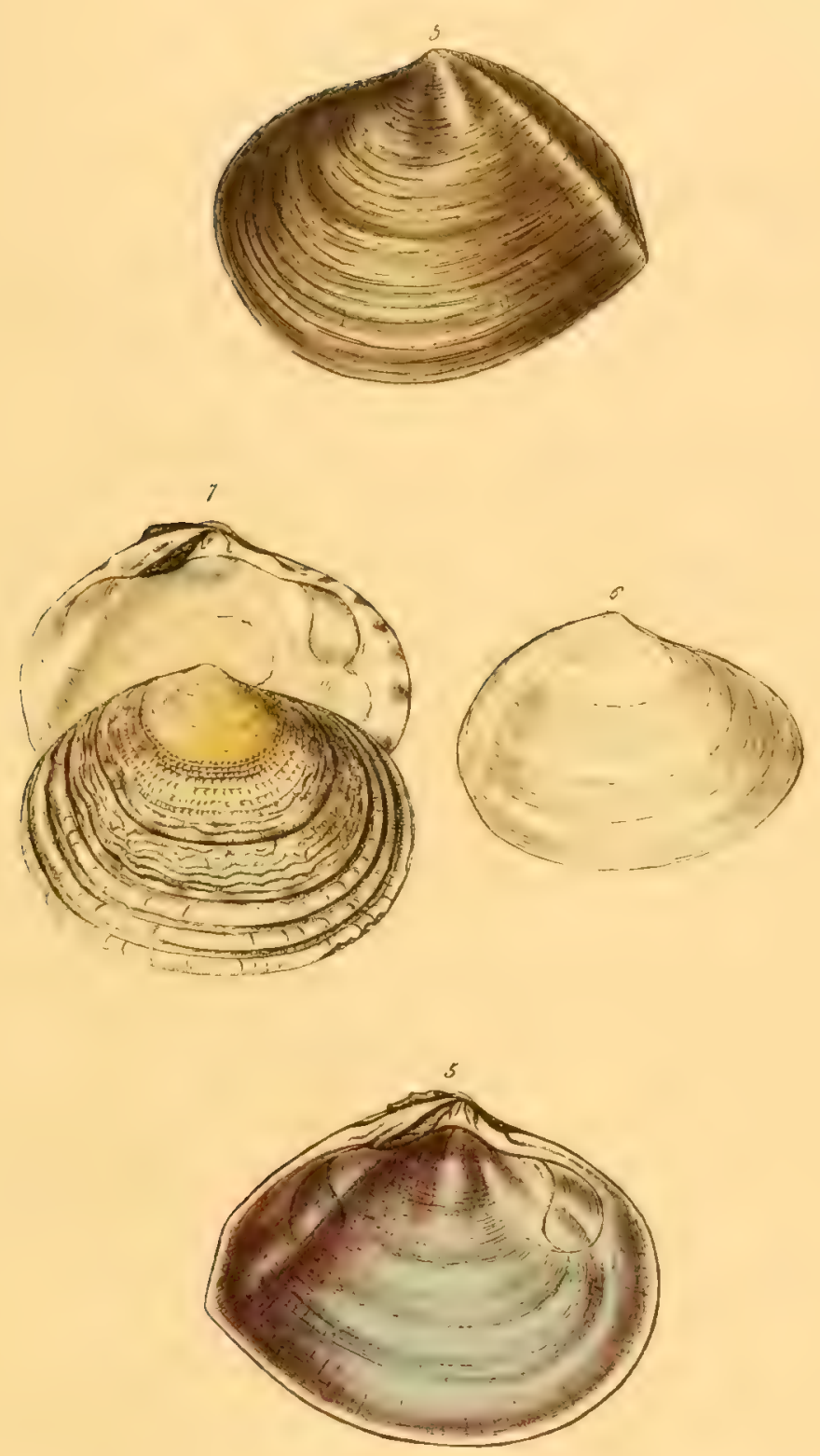

CUMINGIA.

Plate XLIX.
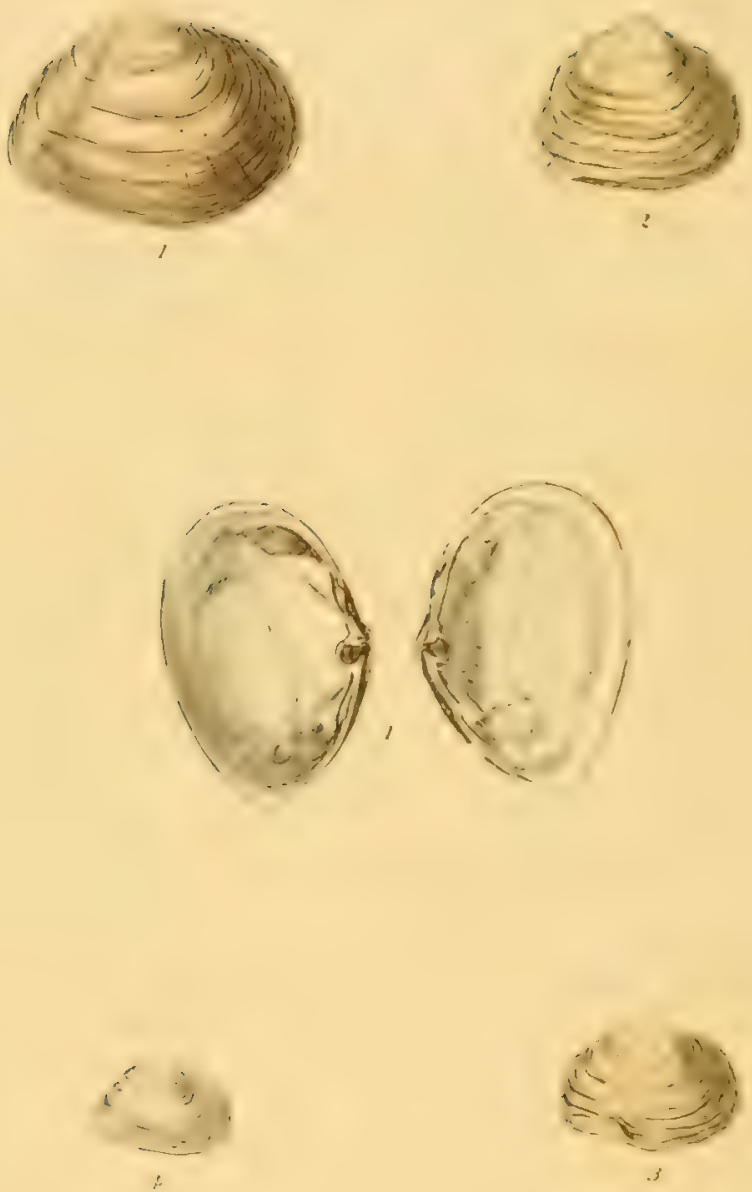

Fig 7. Cumingia mutica

.. 3 .................. limetlesa. 
We confess that there are few instances on record in which a naturalist has been honoured by the introduction of his name into the nomenclature of genera, but in this instance we trust it will be allowed to remain; the indefatigable zeal which has been displayed by Mr. Cuming in collecting Mollusca, both amongst the dangerous islands of the Parific and on the lofty mountains of the Philippines, fully entitle him to such a distinction.

Examples.

Pl. XLIX. Fig. 1.

Cumingia mutica, Sowerby, Proceedings Zool. Soc., 1833, p. 34.

Pl. XLIX. Fig. 2.

Cumingia trigonularis, Sowerby, Proceedings Zool. Soc., 18:33, p. 34.

Pl. XLIX. Fig. 3.

Cumingia lamellosa, Sowerby, Proceedings Zool. Soc., 1833, p. 34.

Pl. XLIX. Fig. 4.

Cumingia coarctata, Sowerby, Proceedings Zool. Soc., 1833, p. 35.

\section{Family 6. LITHOPHAGA.}

Testa suboblonga, latere antico plus minusve hiante. Ligamentum externum. Animal terebrans, nec tubo nec partibus testaceis accessoriis instructum.

This family was instituted by Lamarck, for the purpose of associatin: a small group of terebrating Tropiopoda, which, although inhabiting hard calcareous rocks, differ from the Tubicola and Pholadaria, not only in the growth of their shells, but in the absence of any testaceous tube or accessory pieces.

In addition to the two genera now included in this family, a third wat 
added by Lamarck under the title of Tenerupis. This genus, as its name implies, was made up of certain species of Linnican Veneres, supposed by him to possess the same property of terebrating as that which serves to characterize the Lithophaga. Sowerby has, however, satisfactorily shown that the Lanarchian Tenerupes are merely cast into the carities in which they dwell by force of accident, and has accordingly removed them from this family to that of the Conchecea. He there unites them with certain other allied species of Linnaan and Lamarckim Veneres, under the generic title of P'ullastru, as will be seen in our observations on that genus. The following are the two genera into which the Lithophaga are divided:

\section{Saxicava.}

Petricola.

\section{SAXICAVA, De Bellevue.}

Testa transversa, irregularis, pleruncpue oblonga, inaeguilateralis, subinrquivalvis, latere antico hians. Cardo testre junioris dentibus intcrdum duobus minutis, obtusis, indistinctis; adultre obsoletis. Ligamentum externum. Impressio muscularis pallii sinu nullo.

The shell of Saxicava presents such a diversity of character at different periods of growth, that the same species has been assigned to two or three different genera; and eren Lamarck has not escaped this important error; for example, the Hiatellu arcticu of Daudin and Lamarck, the Solen minutus of Chemnitz and Lamarck, the Mytilus rugosus of Linnxeus, and the Byssomya of Cuvier and De Blainville, are all one and the same species, the Saxicava rugosa. In the young state, when covered with small spines, it is the Hiatella arctica ; still younger, it is the Solen minutus; but in a more advanced state, when the spines are lost, the teeth become obsolete, and the shell altogether assumes an irregular 
growth, from its habit of terebrating ${ }^{*}$, it is the well-known Saxicava rugosa of authors.

The shell of Saxicava may be described as being transverse, irregular.

* In order to show the diversity of opinion that still exists as to the means employed by many of the Mollusca for terebrating or boring, we extract the following elaborate report, from the 'Athenæum,' of an interesting discussion that took place on the subject in the Geological Section at the recent meeting of the British Association at Plymouth.

"Mr. W. Walker observed, that the Saxicava rugosa appears to be the prevailing perforator of the limestone rocks; and that these operations have been carried on during such long periods, as to 'destroy rocks and make deep water where shoals previously existed.' The blocks of Portland stone to which the buoys were formerly attached, in two or three years were punctured on the surface and also deeply perforated by the Saxicava; and in the seawalls of Devonport Dockyard, also of Portland stone, below the low-water level of spring tides the stone is honey-combed and frittered away. At low-water mark are the animals in their holes, higher up their empty shells, and above high water their perforations only are to be found. From these circumstances it appears, that all the limestone rocks around Plymouth were under water within the period during which the Saxicave was the great agent in the destruction of the rocks. In some cases the rocks are protected from these ravages by a coating of Balani, etc., which cover the rock; and in other places, deposits of mud and sand are formed over the rocky bottom, and there the operations of Saxicava and Pholas necessarily cease. Since the Breakwater was erected, the water over the rocks near the Citadel has been diminishing, from the accumulation of mud and sand, and an anchorage is forming where nothing but rocks previously existed.

"Mr. De la Beche stated, that the raised beaches and attendant phænomena at Plymuuth had been first ascertained many years since by Mr. Hennah. The perforations were made apparently by several other animals as well as Saxicava, and he considered these perforations chiefly destructive by exposing a greater amount of surface to the action of other agents, such as carbonic acid.

"Dr. Buckland remarked, that with regard to the specimens of perforated rocks, some from Mount Batten were decidedly neither the work of Saxicava nor Pholas, but precisely resembled some detected by Mr. Greenough in Boulogne, which were the work of common garden-snails (Helix aspersa).

"At Tenby, Mr. Phillips and Dr. Buckland had observed the same kind of perforations; and Mr. Sopwith had noticed them as occurring commonly in Northumberland, on the underside of overhanging shelves of mountain-limestone. The holes made by the Pholas and Saxicava are smaller at the aperture, and increase inward as the shell grows, always assuming its shape. Those made by the snails are largest in the aperture, irregular in form and direction, so as often to trench upon one another. Dr. Buckland attributed the perforations of the 
generally oblong, inequilateral, rather inequivalve, and gaping at the anterior side. In the young shell the hinge is sometimes furnished with two indistinct, minute, obtuse teeth, but in the adult they become obsolete. The ligament is external, and there is no sinus observable in the muscular impression.

\section{Example.}

\section{Pl. L. Fig. 1 to 4 .}

Saxicava rugosa, Lamarck, Anim. sans vert., new edit., vol. vi. p. 152. Mytilus rugosus, Linnæus.

Byssomya (rugosa?), De Blainville.

Hiatella arctica (testa junior), Lamarck.

Solen minutus (testa minuta), Lamarck.

Pholas to the solvent powers of an acid secretion softening the rock, which would afterwards be worn away by the rasping action of the shell; those produced by the land-snails he also attributed to the action of acid secreted in very small quantities by the foot of the animal during its daily retreat to these habitats, through very long periods of time. Apertures such as these, occurring at great heights and far inland, could therefore no longer be adduced in proof of elevation.

"Prof. Owen objected to the mode of accounting for the perforations of the Pholas and other boring Mollusca by acid secretions, because rocks which are not calcareous are also bored by bivalves. He attributed the formation of these cavities to the constant current of water around the shells, produced by extremely minute, vibratile cilia, which move incessantly, and independently of the will of the animal. The cilia cover the whole of the gills (branchix) and other parts of the animal, and produce currents in the water necessary to its existence; when lodged in the rock, the currents increase in intensity as the shell proceeds inwards.

"Mr. J. Phillips considered the small holes covering the surface of some of the rocks due to a different cause from the deep excavations occupied by the Pholas and Saxicava; besides the boring Mollusca, several other animals are known, which have a characteristic mode of perforating rocks. He alluded to the beautiful regularity of the holes made by the Pholas in proof of their being formed by the shell, and not by currents of water.

"Mr. De la Beche observed, that free carbonic acid, applied to the limestone, will convert it into a bicarbonate, soluble in water, and the animal might apply the acid exhaled in breathing to the purpose of softening the rock.

“Dr. Buckland, in reply to Prof. Owen's remarks, observed, that if the perforations were 
SAXICAVA.

Plate L.
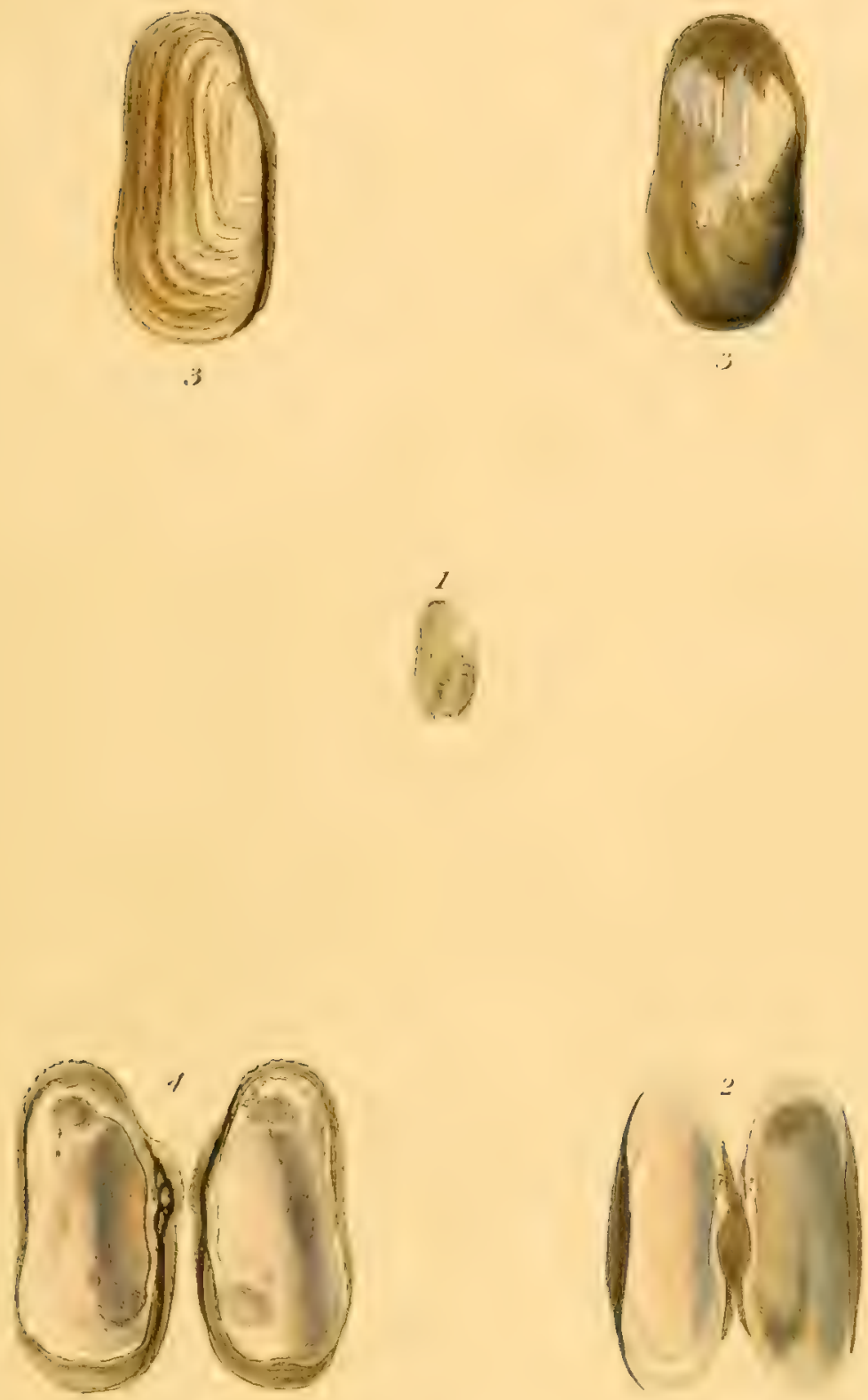



\section{PETRICOLA, Lamarck.}

Testa æquivalvis, inæequilateralis, transversa, subtrigona vel oblonga ; latere postico rotundato, antico plus minusve attenuato, plerumque subhiante. Cardo dentibus duobus in utrâque valvâ, vel acutis, recurvis, vel brevibus, obtusis. Ligamentum externum. Impressio muscularis pallii sinu magno.

This is another genus in which the shell assumes a considerable irregularity of growth from its habit of terebrating; it may, however, be readily distinguished from that of Saxicura; the teeth are more fully developed, and there is a large sinus in the palleal impression.

owing to currents, the greatest force would be exerted at the aperture, which would, consequently, be the largest part. At Lyme Regis, the interior of the perforation made by Pholades was marked by parallel circular strix, owing to the mechanical action of the shell, which rasps away the rock, and necessarily increases the size of the cavity in exact proportion with its growth. In the other case of perforation attributed to land-snails, the action was entirely chemical, and their agency was only adduced to account for appearances which the Pholades could not possibly have occasioned.

"Prof. Henslow mentioned perforations in limestone rocks from Barnstaple, in the Cambridge Museum, which were hollowed by the chemical action of muriate of lime having converted some parts into carbonate of suda.

"Mr. R. A. C. Austen considered the borings of shells were not to be accounted for by the action of acid, as the operations of the Saxicava rugosa were not confined to limestone rocks. In Tor Bay the trap rocks are also perforated, and the old red sandstone is frequently found bored by Pholades. He also objected to the other cavities being formed by land-snails, there being but one time of the year when they remain fixed to a particular spot, and then a film (epiphragm) is formed over the mouth of the shell, which is afterwards left attached to the rock or other object, rendering it improbable that another snail would adhere to the same place.

" Dr. Buckland, in reply to a question by Mr. H. E. Strickland, mentioned that the locality of the perforatiuns by snails at Boulogne was six miles inland; at Alston Moor and at other places it was also far from the sea."

VOL. I. 
The shell of Petricola is described as equivalye, inequilateral, transverse, somewhat triangular or oblong, with the posterior side rounded; the anterior is more or less attenuated, and generilly a little gaping. The hinge is furnished with two teeth in each valve, either acute and recurved, or short and obtuse. The ligament is external.

\section{Examples.}

Pl. LI. Fig. 1 and 2.

Petricola Pholadiformis, Lamarck, Anim. sans vert, new edit, vol. vi. p. 159.

$$
\text { Pl. LI. Fig. 3. }
$$

Petricola dactylus, Sowerby, Genera of Shells, No. 15.

$$
\text { Pl. LI. Fig. } 4 .
$$

Petricola ochroleuca, Lamarck, Anim. sans vert., new edit., vol. vi. p. 157.

Tellina fragitis, Linnæus.

Tellina ochroleuca, Wood.

PI. LI. Fig. 5. (fossil).

Petricola rupestris, Sowerby, Genera of Shells, No. 15. Venus rupestris, Brocchi.

$$
\text { Pl. LI. Fig. } 6 .
$$

Petricola subglobosa, Sowerby, Genera of Shells, No. 15.

\section{Family 7. NYMPHACEA.}

Testa ad extremitates laterales raru subhians; dentibus cardinalibus duobus aut pluribus in eâdem valvâ; umbonibus prominulis. Ligamentum externum.

'This family was instituted by Lamarck for the association of a nume- 
PETRICOLA.

Plate LI.
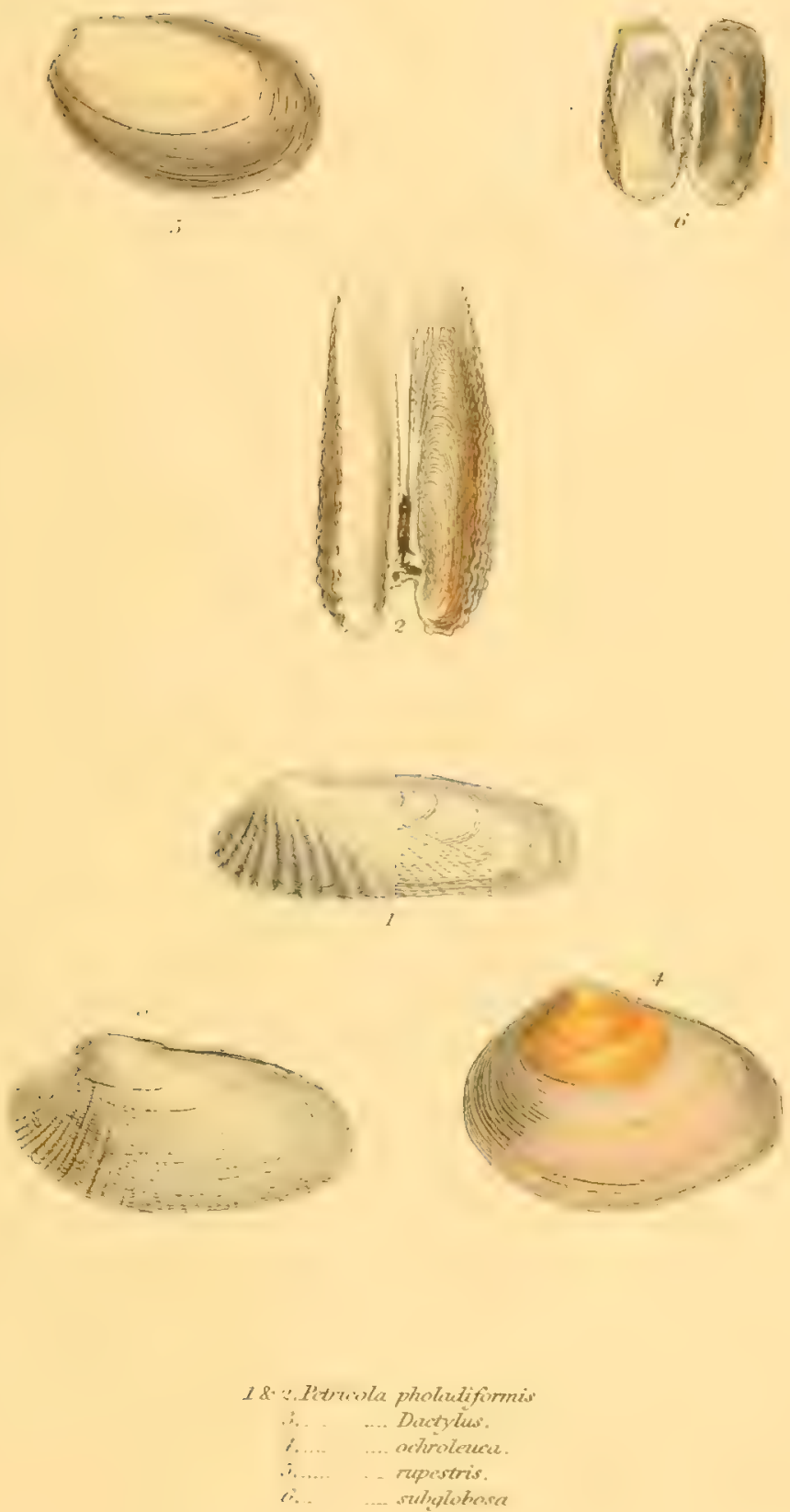

rous assemblage of species, partaling somewhat of the characters of the solenucen. They present, howerer, a diversity of form, and considerable difficulty arises in arranging them. Several alterations have been proposed for improring the subdivision of the Nymphacea, one of which, the setting apart of the genera Corbis and Lucina in a separate and distinct family, might perhaps have been done without injury to the general classification; we do not, however, consider it necessary. The genus Asturte, which Lamarck included in this family under the title of Crassina, most assuredly belongs to that of the Conchucea, and is removed accordingly; and his genera Psemmoten and Tellinides are altogether abandoned. By these alteritions and the addition of the genus Guleom$m a$, we enumerate eight genera as belonging to this family:

$\begin{array}{ll}\text { Sanguinolaria. } & \text { Corbis. } \\ \text { Psammobia. } & \text { Lucina. } \\ \text { Galeomia. } & \text { Donax. } \\ \text { Telina. } & \text { Capsa. }\end{array}$

SANGUINOLARIA, Bruguière.

Testa aquivalvis, inerquilateralis, transtersa, subelliptica, compressa, tenuis, utroque latere subhians; marginibus arcuatis, non parallelis. Dentibus cardinalibus duobus approximatis, interdum bifidis, in utrâque valvâ; fulcro prominente. Impressio muscularis pallii sinu magno.

Lamarck includes with his Sanguinolarie certain species, which are now by common consent removed to the genus Psammobia; and Sowerby has introduced two species that Lamarck had arranged with his solenes. These alterations fully show that the Nymphacea might almost with equal propriety have been placed inmediately after the solenucen, 
the genus Sanguinolaria being exactly intermediate between the genera Solecurtus and Psammobia.

The shell of Sanguinolaria is equivalve, inequilateral, transverse, somewhat elliptic, compressed, thin, and a little gaping at both sides; the nargins curved and not parallel to each other. There are two cardinal teeth situated close to each other in each valve, sometimes bifid; and there is also a prominent testaceous appendage or fulcrum on the unbonal margin, as in many of the solenacen. The muscular impression of the mantle exhibits a large sinus.

\section{Examples.}

PI. LII. Fig. 1 and 2.

Sanguinolaria rosea, Lamarck, Anim. sans vert, new edit, vol. vi. p. 169.

Tellina rosea, Gmelin.

Solen sanguinolentus, Dillwyn.

Psammobia rosea, Deshayes.

Pl. LII. Fig. 3 and 4.

Sanguinolaria diphos, Sowerby, Genera of Shells, No. 25.

Solen diphos, Chemnitz.

Solen rostratus, Lamarck.

Psammobia rostrata, Deshayes.

Soletellina radiata, De Blainville.

$$
\text { PSAMMOBIA, Lamarck. }
$$

Testa transversa, oblonga vel ovato-oblonga, lateribus subhiantibus; epidermide tenui, corneâ, induta. Cardo, in valvâ alterâ dentibus brevibus duobus, plerumque bifidis ; in altera unico. Ligamentum externum. Impressio muscularis pallii sinu maximo. 
Plate LII.
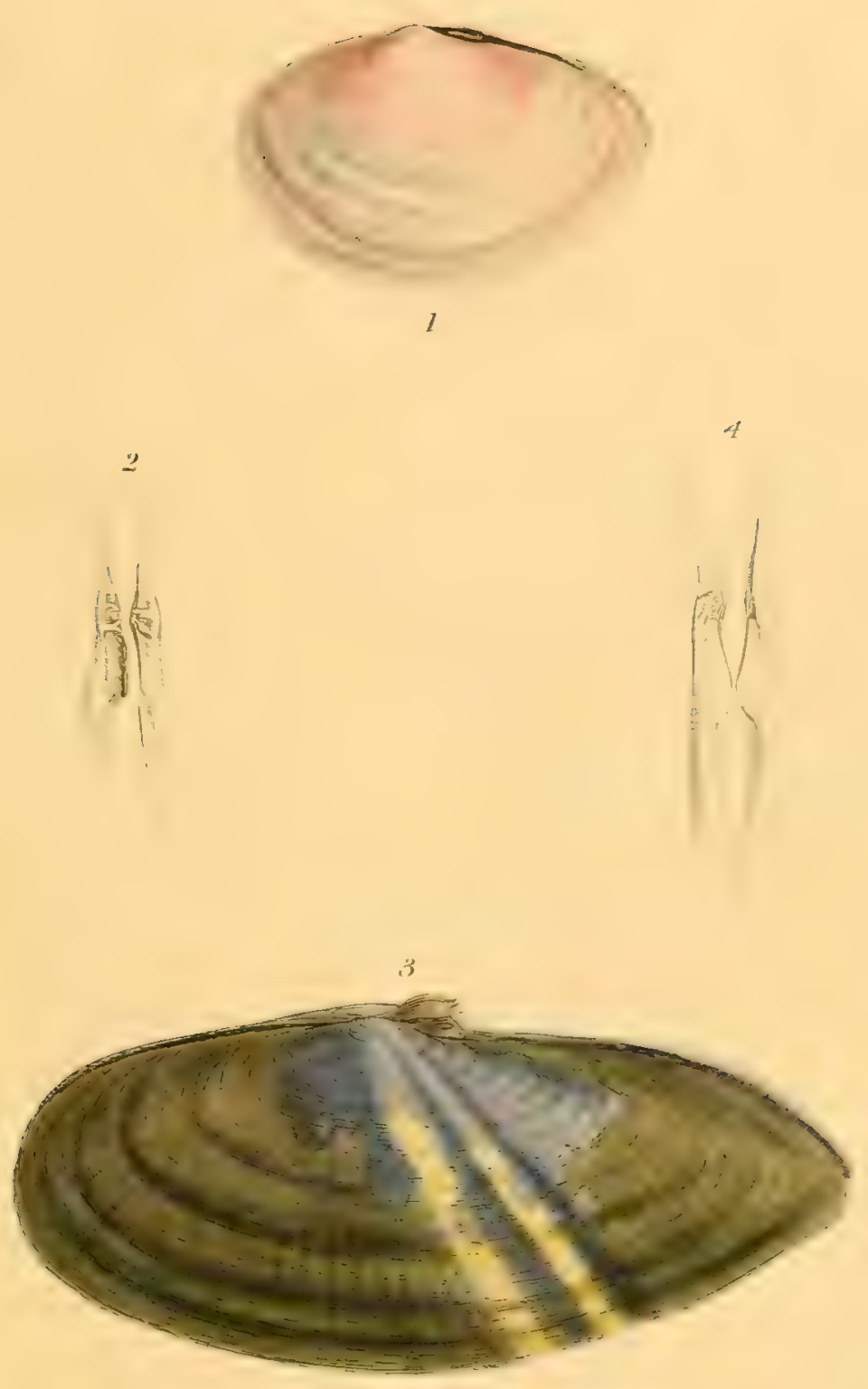

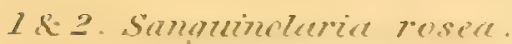

$3 \times 4$. Diphles. 


PSAMMOBIA.

Plate LIII.
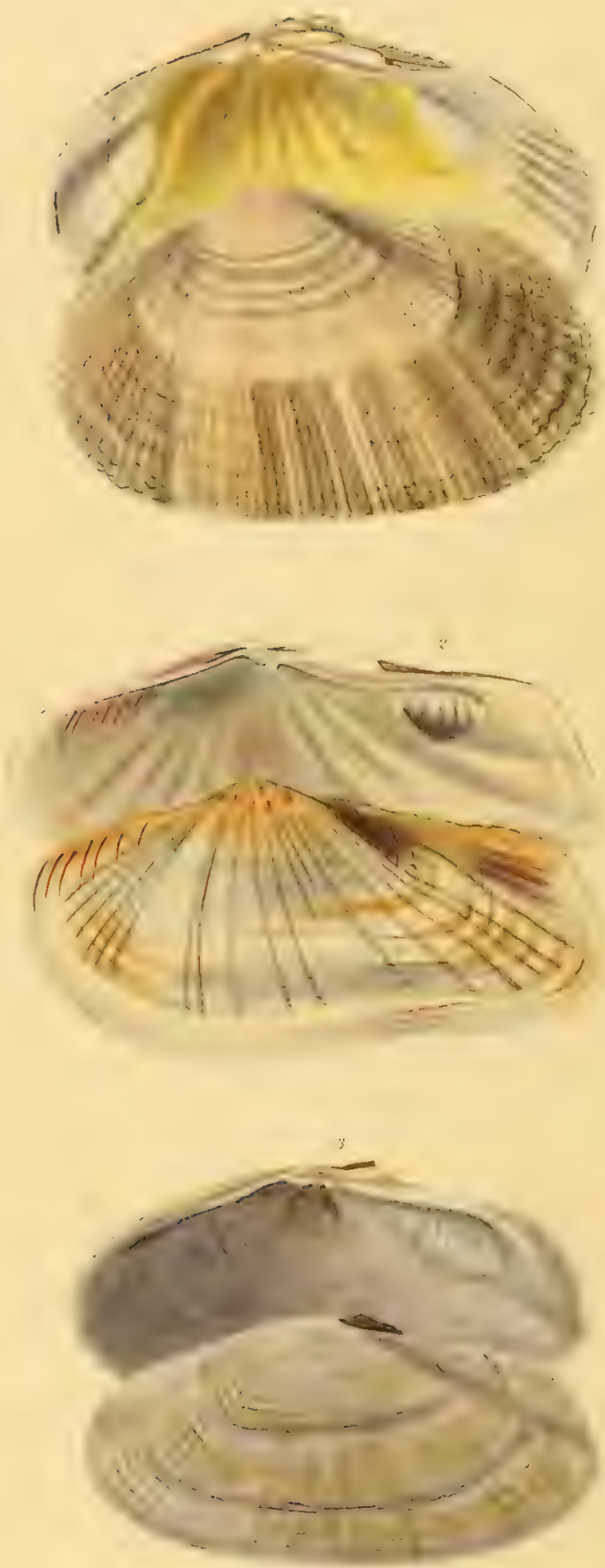
The Psammobix, which serve to connect the genera Sanguinolurio and Tellinu, are chiefly characterized by their shell being always more or less angular at one end, with the cardinal teeth short and mostly bifid. The species which constitute the genus Psammotca of Lamarck were separated from his Psammobix on account of an assumed deficiency of the cardinal teeth, but this was purely accidental*; they were therefore reunited by De Blainville, Sowerby and others, the first of whom proposed the new title of Psammocola.

The shell of Psammobia is described as being transverse, oblong, or ovately oblong, gaping a little at the sides, and covered with a thin horny epidermis. The hinge consists of two short bifid teeth in one valve, and one in the other, with an external ligament.

The palleal impression exhibits a very large sinus.

Examples.

PI. LIII. Fig. 1.

Psammobia rugosa, Sowerby, Genera of Shells, No. 35.

Venus deflorata, Gmelin.

Sanguinolaria rugosa, Lamarck.

Psammocola rugosa, De Blainville.

Pl. LIII. Fig. 2.

Psammobia violacea, Sowerby, Genera of Shells, No. 35.

Psammotea violacea, Lamarck.

Psammocola violacea, De Blainville.

Pl. LIII. Fig. 3.

Psamobia cerulescens, Lamarck, Anim. sans vert, new edit., vol. vi.

p. 174. Sowerby, Genera of Shells, No. 35.

Psammocola carulescens, De Blainville.

* Sowerby asserts that the Psammotea were characterized from broken specimens : this is most probable; Lamarck himself, indeed, pronounces them to be "Psammobies dégénéríes." 


\section{GALEOMMLA, Turton.}

Testa temuis, parra, oblongo-ovata, axpuiralvis, a'quilateralis, margine ventrali hians. Dens cardinalis in utrâque valvâ unicus, ligamento parvo, duplici, partìm interno, partìm externo. Impressio muscularis pallii interrupta, sinu nullo.

The senus: Galcomma was introduced by Dr. Turton, and characterized from some specimens found on our own coast. It also includes a species from the Mauritius, described by Lamarck as a Premmobia, though differing materially from his other Psummobire both in size and general aspect. The animal, which hats been carctully examined by Gray, is said to agree in some particulars with that of Gastrochena; he does not, however, express any opinion as to the situation it should occupy in the general classification, and therefore leaves us in doubt as to the propriety of retaining it with the Nymphacea.

The shell of Galeomma is described as being thin, small, oblongoorate, equivalve, equilnteral, and ganjug at the ventral margin. There is one cardinal tooth in each valve, and the ligament is small and duplex, partly internal and partly external.

The muscular impression of the mantle is interrupted, but without exhibiting any sinus.

$$
\text { Examples. }
$$

Pl. LIV. Fig. 1 to 3.

Galeomma 'I'Urtoni, Sowerby, Zool. Journal, p. 361. pl. 13. f. 1. Genera of Shells, No. $\$ 7$.

Pl. LIV. Fig. 4 and 5.

Galeomma Mauritiana, Sowerby, Genera of Shells, No. 37. Psammobia aurantia, Lamarck.

Galeomma aurantia, Deshaves. 


\section{GALEOMMA.}

Plate LIV.
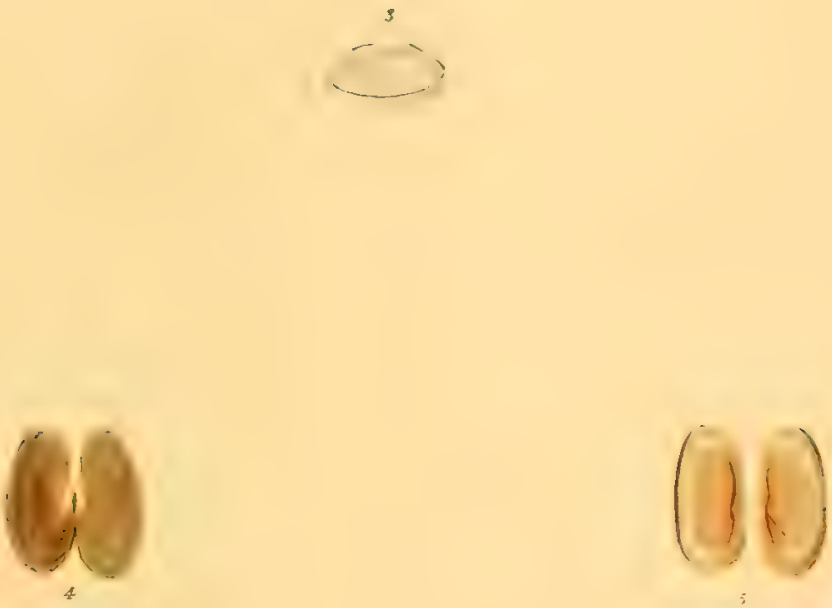

1.2.3. Galeomma Turtoni.

7.5........... Mauritiana. 


TELLINA.

Plate LV.
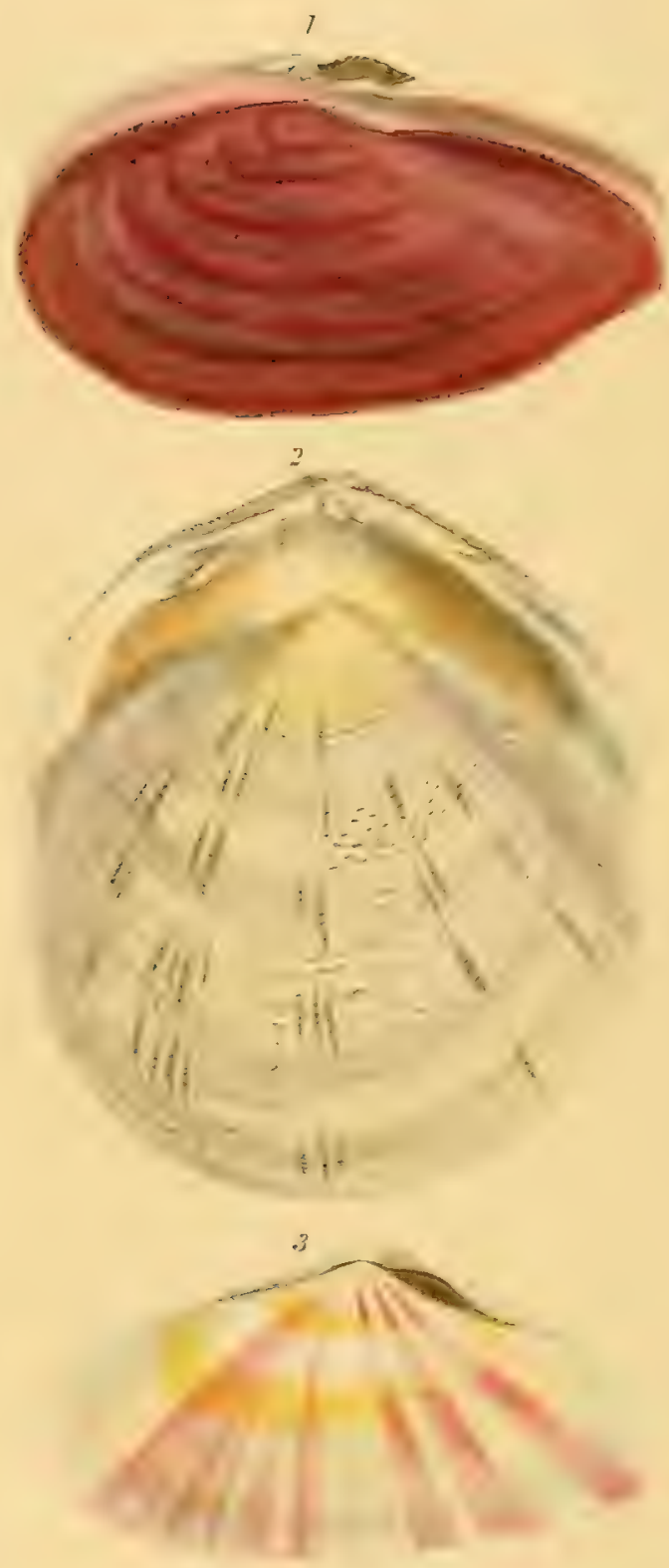

1. Tillina opercularis.

?. irelimele.

3 resliater. 


\section{TELLINA, Linnæus.}

Testa transversa vel orbicularis, subrequivalvis, inæequilateralis, planulati. latere antico subrostrato, angulato, margine rentrali plerumque irregulariter flexuoso; dentibus in utritque valva cardinalibus plerumque duobus, lateralibus duobus, sapè remotis, interdum nullis. Impressio muscularis pallii sinu maximo.

The genera Tellina and Tellinides of Lamarck are here united in accordance with the opinions of De Blainville and Deshayes, who clearly demonstrate that the distinguishing characters which Lamarck and Sowerby have assigned to the shell of the latter, namely, the absence of the irregular flexuosity on the anterior ventral margin, and also of the lateral teeth, are but an inconstant variety of growth.

We have therefore described the shell of Tellina as being transverse or orbicular, nearly equivalve, flat, with the anterior side somewhat bealied or angular, and generally irregularly flumose at the ventral margin.

There are two lateral and two cardinal teeth in each valve; the former, however, are often remote, and sometimes altogether wanting. The muscular impression of the mantle has a very large sinus.

\section{Examples.}

Pl. LI. Fig. I.

Tellina opercularis, Sowerby, Genera of Shells, No. 31. Tellina operculata, Gmelin. Tellinu rufescens, Chemnitz.

Pl. LV. Fig. 2.

Telinna scobinata, Linnæus, Syst. Nat., p. 1119. Lamarck, Anim. sans vert., new edit, vol. vi. p. 201. Enc. Méth., pl. 291. f. 4. 
PI. LV. Fig. 3.

Tellina radiata, Linnæus, Sist. Nat., p. 1117. Lamarck, Anim. sans vert., new edit., vol. vi. p. 187. Enc. Méth. pl. 289. f.2.

PI. LVI. Fig. 1.

Teluina rosea, De Blainville, Manuel de Malacologie, p. 549.

Tellinides rosea, Sowerby.

Pl. LVI. Fig. 2.

Tellina Timorexsis, De Blainville, Manuel de Malacologie, p. 450. pl. 72. f. 2.

Tellinides Tïmorensis, Lamarck.

CORBIS, Cuvier.

Testa transversa, xquivalvis, subxquilateralis, umbonibus oppositè incurvis; dentibus in utrìque valvâ cardinalibus duobus, et lateralibus duobus, postico ad cardinem propius admoto, antico remoto. Ligamentum externum. Impressio muscularis pallii simplex, integra.

This characteristic genus was instituted by Cuvier; its beautiful shell may be easily recognised by the longitudinal and transverse fimbriated undulations or lamellar ridges crossing the external surface of the valves, and diverging also from the unbones to the margin. It is always of a clear white colour, sometimes tinged or radiated with pink, and is thus described.

Shell transverse, equivalve, nearly equilateral, with the umbones curveri inwards. There are two cardinal teeth in each valve, and also two lateral, one of which is situated near the cardinal teeth, the other remote, near the termination of the ligament which is external. The muscular impression of the mantle is simple and entire. 
TELLINA.

Plate LVI.
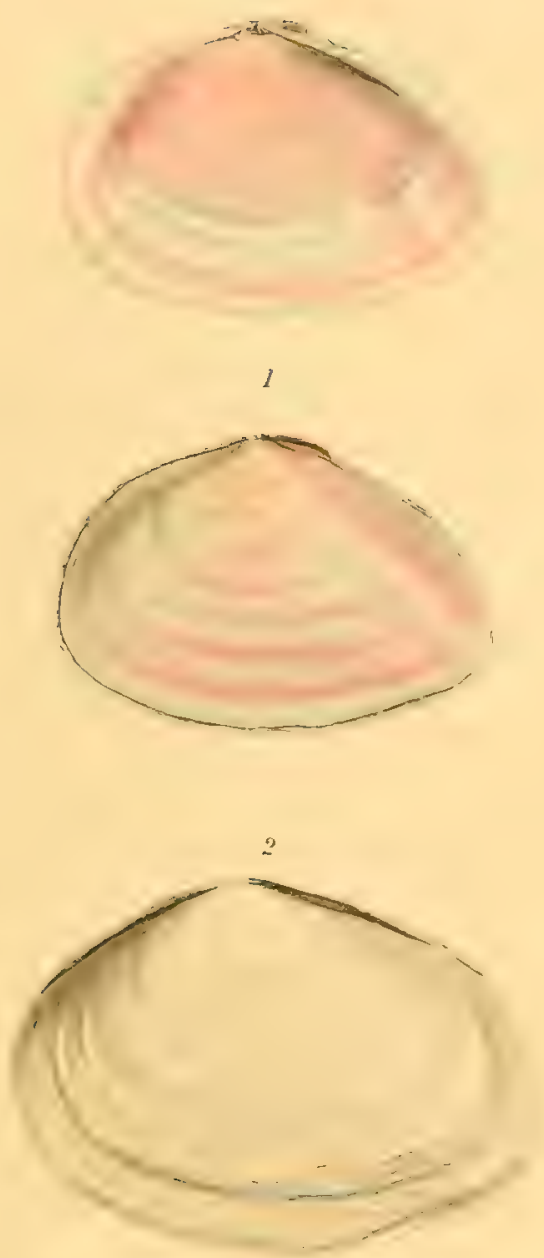

I Tillinides resed

$\therefore \quad$ limeriensts 


CORBIS.

Plate LVII.

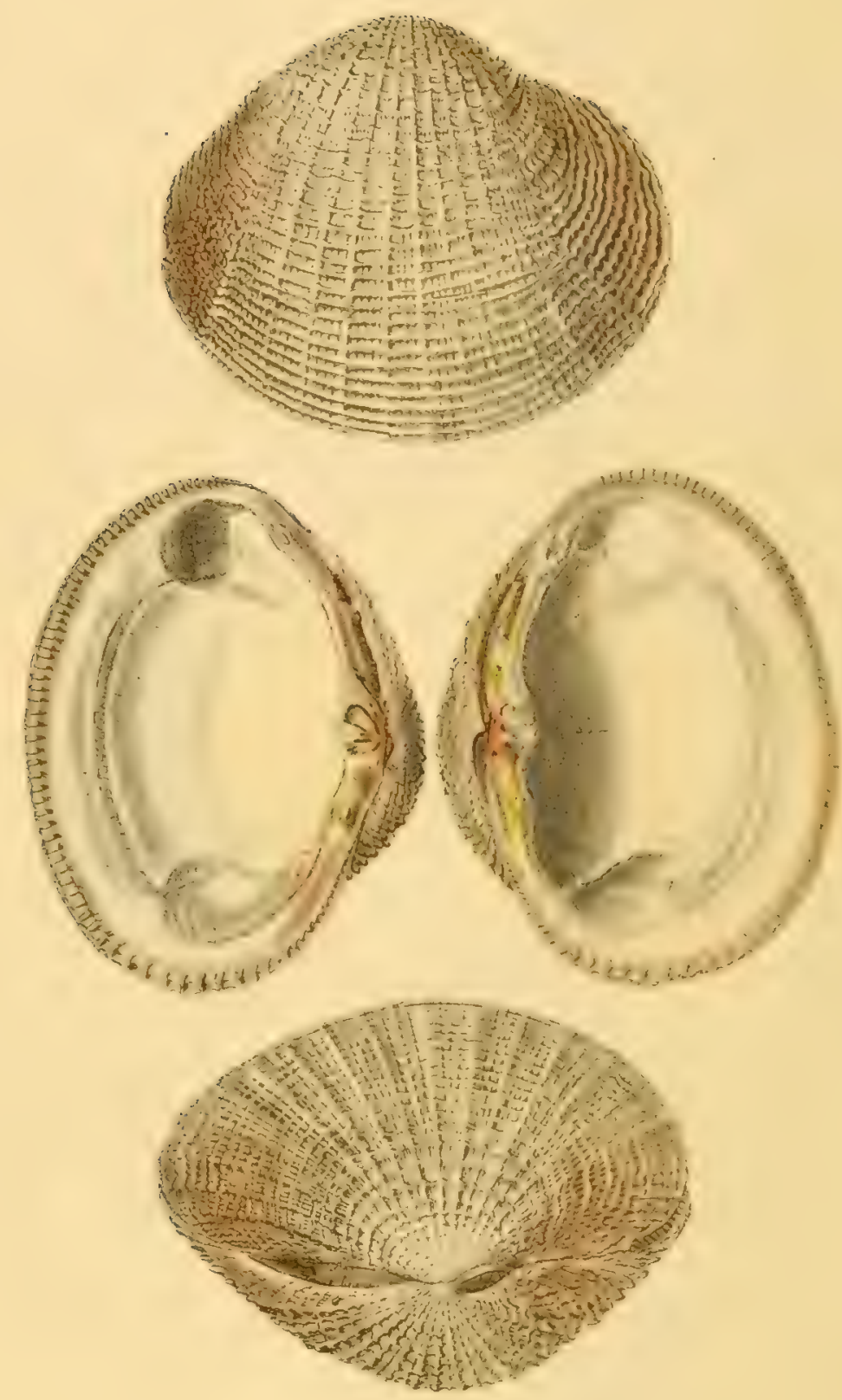

Corbis fimbriate. 

CORBIS.

Plate LVIII.
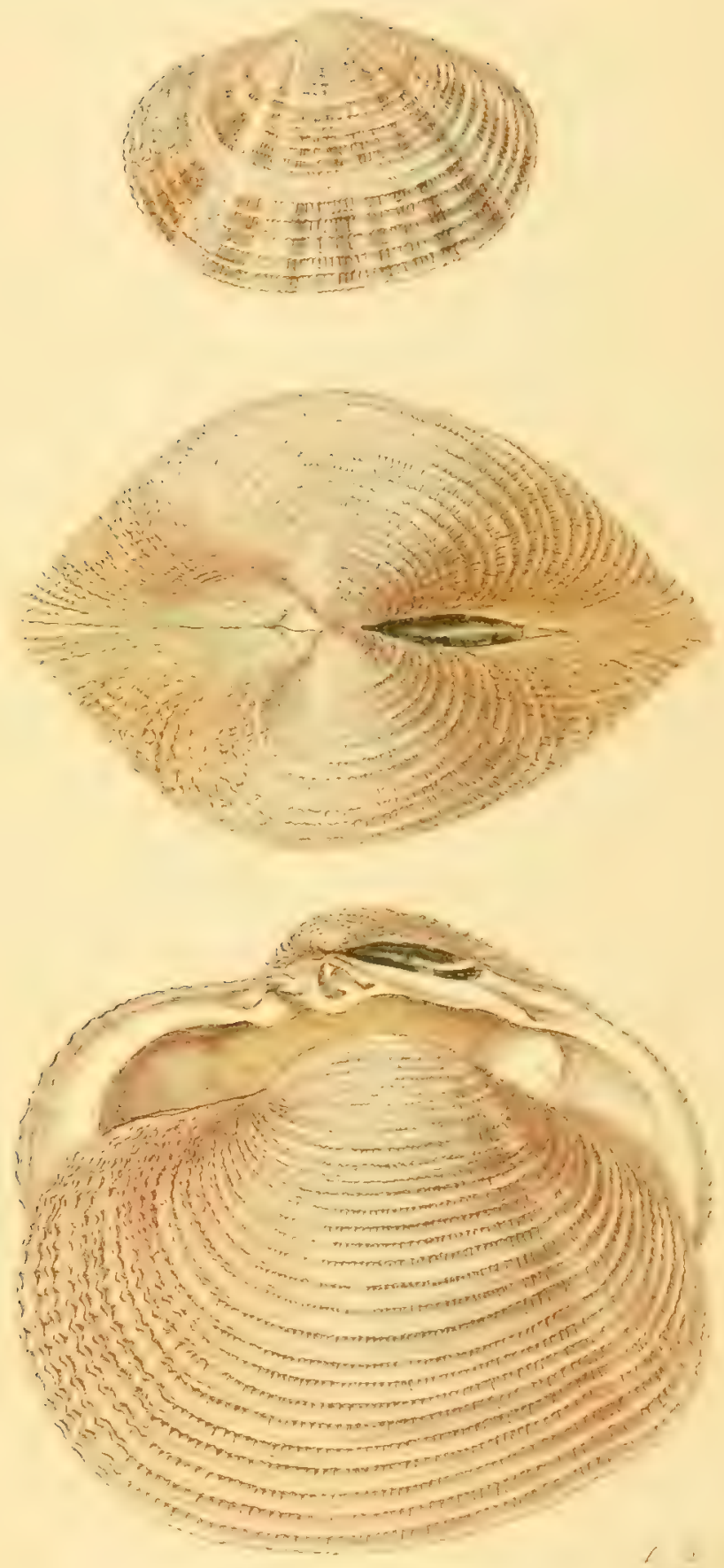
Examples.

Pl. LVII. Fig. 1 to 3.

Corbis fimbrata, Cuvier, Règne Animal, vol. ij. p. 481. Enc. Méth., pl. 286. f. 3.

Venus fimbriata, Linnæus.

Pl. LVIII. Fig. 4 to 6.

Corbis Soverbir, Nobis*, Proceedings Zool. Soc. 1841.

\section{LUCINA, Bruguière.}

Testa suborbicularis, aquivalvis, inæequilateralis, subdepressa, umbonibus parvis, acutis, obliquis. Cardo variabilis, modò dentibus duobus divaricatis, modò edentulus. Dentes laterales in alterâ valvâ utrinque unus; in alterâ duo, interdum obsoleti, anticus ad cardinem propiùs admotus. Impressiones musculares distantes; antica in fasciam interdum prelongam producta. Impressio muscularis pallii simplex, distinctissimè imbuta.

The genus Lucina of Bruguière comprehends a natural assemblage of species, selected from the Tellina and Veneres of Limneus; their shells exhibit a peculiar similarity of form, but are remarkable for the variety of character displayed on the surface of the interior. The hinge varies considerably; in fact, the teeth are so irregular in their development, that they are of little value in drawing up a generic description.

The shell of Lucina is generally of an orbicular form, equivalve, inequilateral, and somewhat depressed, with the umbones small, acute and

* We have had much pleasure in dedicating this beautiful species to Mr. G. B. Sowerby, Jun., author of the 'Conchological Manual,' and engraver of many of the best plates of this work. Our figures of the shell, riewed in the adult and young state, are drawn from two magnificent specimens in the possession of the Rev. Mr. Stainforth.

VOL. I, 
oblique. The hinge has sometimes two divergent teeth, sometimes none ; in one valve there are two lateral teeth, one on each side, the anterior of which is situated near the hinge, and in the other there is but one; these however are often obsolete.

The muscular impressions of attachment are distant from each other, and the anterior one is prolonged in the form of an elongated or ligulate band. The interior of the shell exhibits a simple palleal impression, very strongly marked, and is often junctured with small holes or stria.

Examples.

Pl. LIX. Fig. 1.

Lucina punctata, Sowerby, Genera of Shells, No. 27.

Venus punctata, Linnæus.

Cytherea punctata, Lamarck.

Lentilaria punctata, Schumacher.

PI. LIX. Fig. 2.

Lucrea Chibdrexi, Gray, Amals of Plilosophy, 1824. Sowerby, Genera of Shells, No. 27.

P1. LIX. Fig. 3.

Lucina Jamaicensis, Lamarck, Anim. sans vert., new edit., vol. vi. p. 223. Sowerby, Genera of Shells, No. 27.

Venus Jamaicensis, Chemnitz.

\section{DONAX, Linnæus.}

Testa transversa, xquivalvis, inæquilateralis, latere antico brevissimo, obtusissimo. Dentes cardinales alterius valvæ duo, alterius unicus, supernè bifidus; laterales duo vel unus, plus minusve remoti. Ligamentum externum, breve, plerumque bipartitum, partim post umbones positum. Impressio muscularis pallii sinu magno. 
Plate LIX.

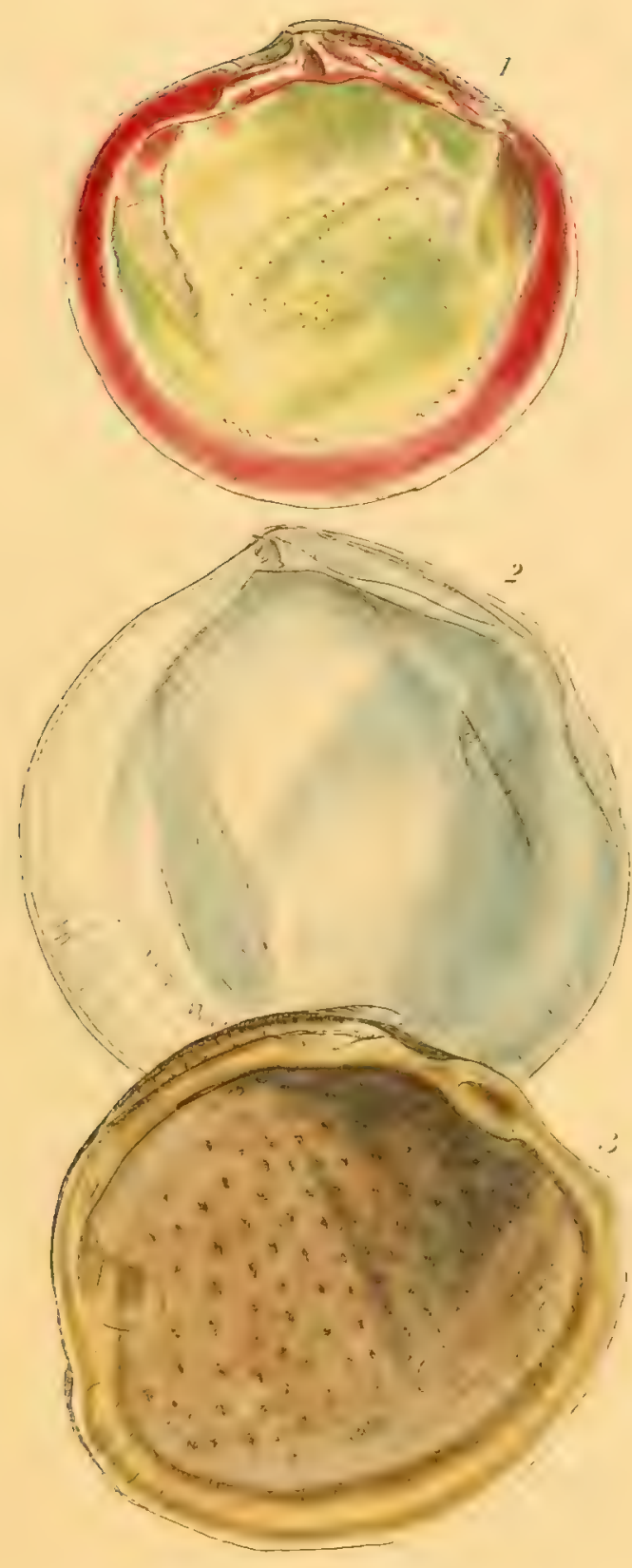

7. Encinere penctuter.

$\therefore \quad(\%) / 11,1)$

3....... Tumertantis 


DONAX.

Plate LX.
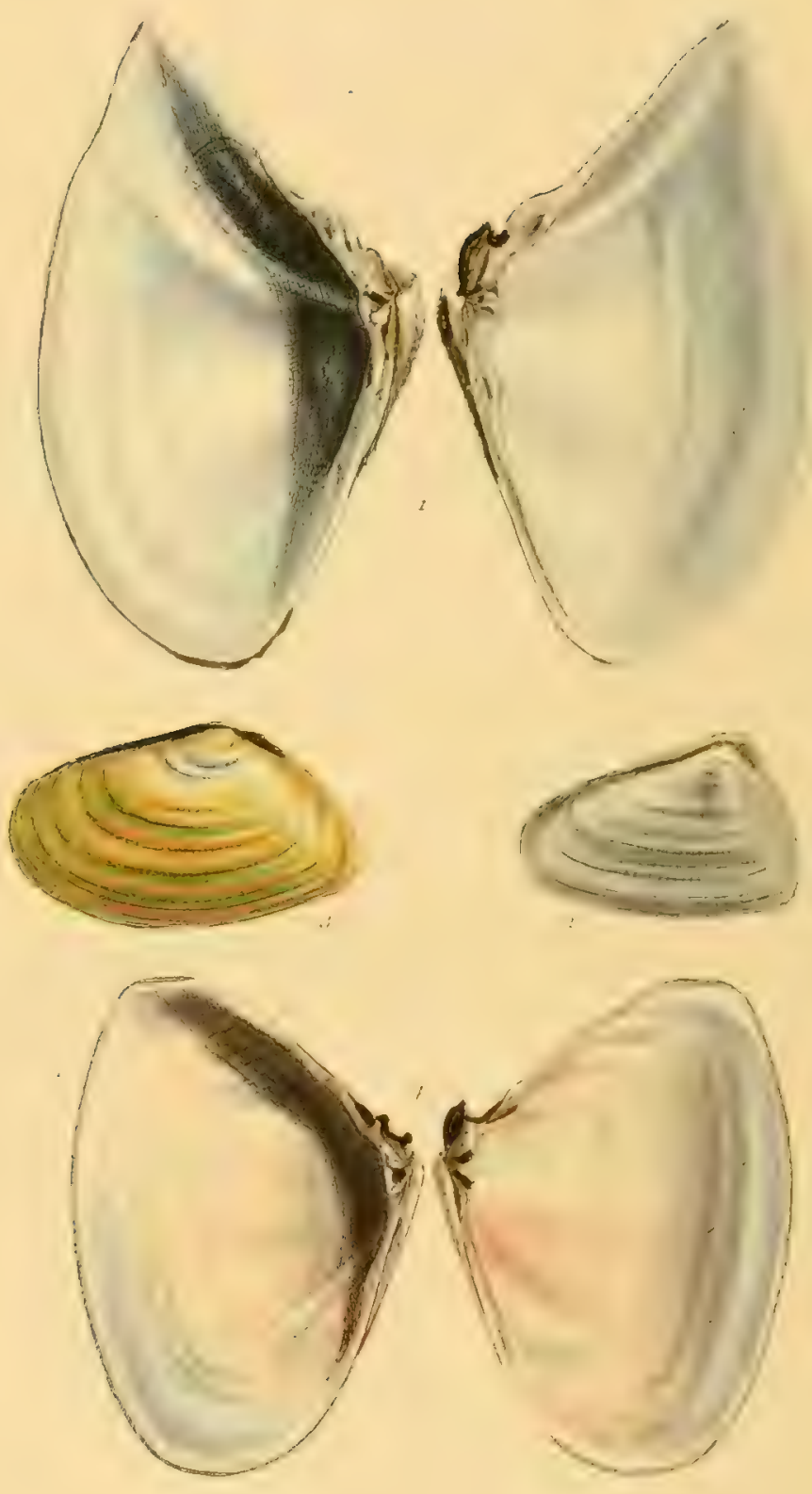

$$
\begin{aligned}
& \text { 1. Drnar Scortim }
\end{aligned}
$$

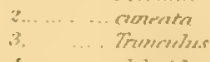

$$
\begin{aligned}
& \text { f. . . . de derites }
\end{aligned}
$$


The shell of Donax is so strongly characterized by its short truncated wedge-shaped form, that the genus remains nearly as entire as in the time of Linneus.

It may be described as transverse, equiralve, inequilateral, with the anterior side very short and obtuse, and the valves more or less crenulated round the inner margin. There are two cardinal teeth in one valve and one in the other, bifid superiorly; there are also one or two lateral teeth in both valves, more or less distant from each other. The ligament is external, short, and generally bipartite, a portion of it being situated under the umbones; and there is a large sinus observable in the muscular impression of the mantle.

\section{Examples.}

PI. LX. Fig. 1.

Donax scortun, Linnæus, Syst. Nat., p. 1126. Lamarck, Anim. sans vert., new edit., vol. vi. p. 239. De Blainville, Manuel de Malacologie, pl. 71 . f. 1.

Donax pubescens (testa junior), Lamarck.

Pl. LX. Fig. 2.

Donax cuneata, Linnæus, Syst. Nat., p. 1127. Lamarck, Anim. sans vert., new edit., vol. vi. p. 240. Enc. Méth., pl. 261. f. 5.

\section{Pl. LX. Fig. 3.}

Donax trunculus, Linneus, Syst. Nat., p. 1127. Lamarck, Anim. sans vert., new edit., vol. vi. p. 248. Enc. Méth., pl. 262. f. 1.

Pl. LX. Fig. 4.

Donax deltoides, Lamarck, Anim. sans vert., new edit., vol. vi. p. 241. Sowerby, Genera of Shells, No. 10.

Donax lavigata? Dillwyn. 


\section{CAPSA, Lamarck.}

Testa transversa, xquiralvis, subinxequilateralis, clausa; dentibus in valvî alterâ cardinalibus duobus, in alterî cardinali unico, cum lateralibus duobus ferè obsoletis. Liģamentum externum. Impressio muscularis pallii sinu magno, oblongo.

This genus may be said to have been instituted by Lamarck; Bruguière lad certainly a prior claim to the name of Capsa, but it was appropriated to another division of Tropiopoda, of which the Psammobia rugosa formed the type. Eren Limarck, in the first instance, acknowledger the genus Capsa as constituted by Pruguière; but on the formation of his genus Sanjumolaria, he retained the title in reference only to the species under consideration, and in this form it has been so universally sanctioned, that we cannot hesitate to adopt it.

The shell of Capsa, which is closely allied to that of Donax, may be described as transwerse. equivalve, rather inequilateral, with the valves closed and never crenulated round the inner margin. The hinge consists of two cardinal tecth in one ralve, and one cardinal with two nearly obsolete lateral teeth in the other. The ligament is external, and the muscular impression of the mantle exhibits a large oblong sinus.

Examples.

PI. LXI. Fig. 1.

Capsa Brasiliensis, Lamarck, Anim. sans vert, new edit, vol. vi. p. 255. De Blainville, Manuel de Malacologie, pl. 71. f. 10. Donax Brasiliensis, Deshayes.

PI. LXI. Fig. 2.

Capsa complanata, Sowerby, Genera of Shells, No. 10. Donax complanata, Montague. Deshayes. 
CAPSA.

Plate LXI.

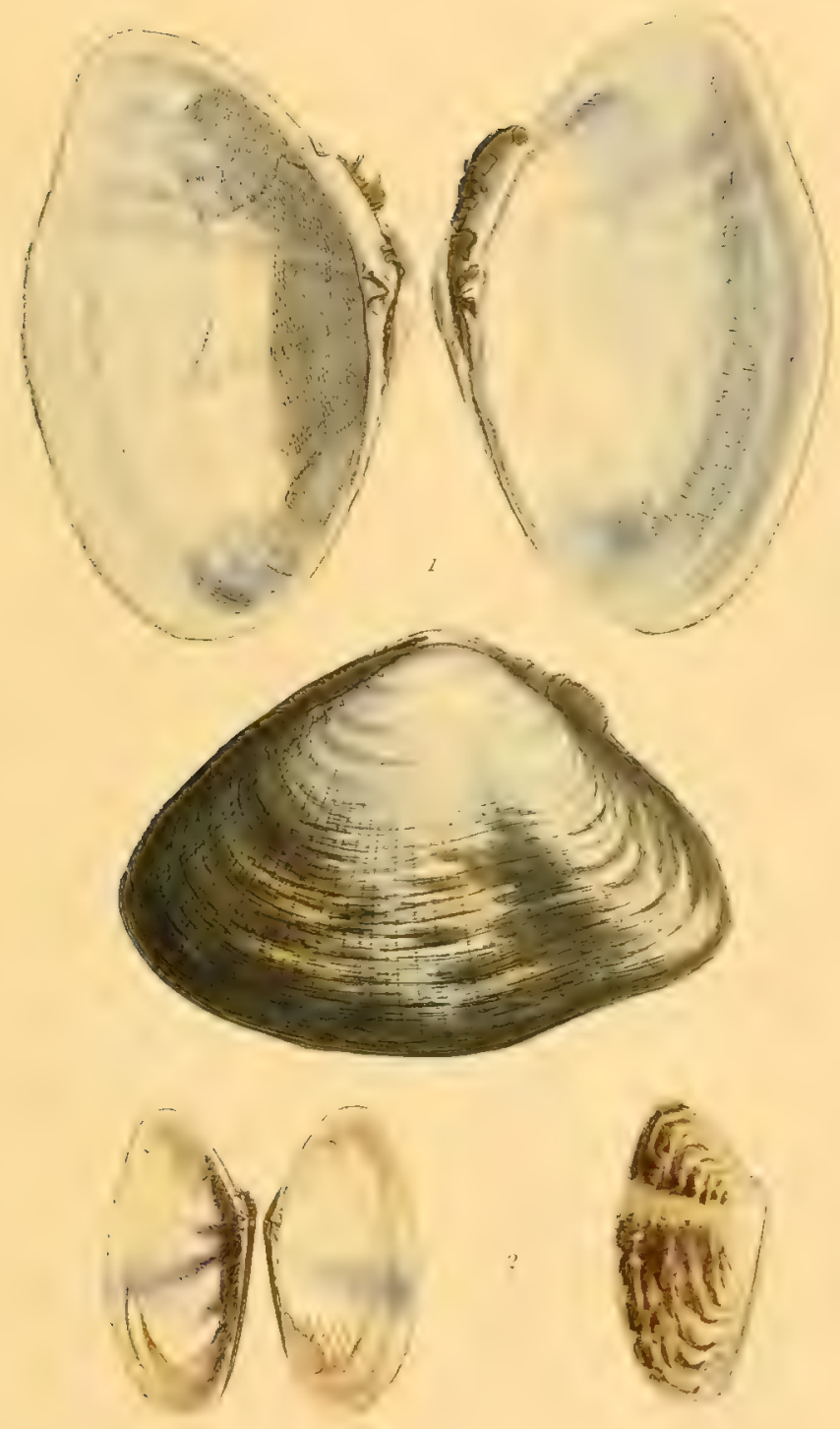





\section{Family 8. CONCHACEA.}

Testa orbicularis, vel transversa; dentibus cardinalibus in valvâ alterà tribus aut pluribus, in alterâ tribus aut minoribus; lateralibus ̨̨uibusdam in utrâque valvâ, interdum nullis.

The Conchacea constitute a numerous family, distinguished above most of the Bimuscular Tropiopoda by the elegance and beauty of their shells. They pass through a considerable variety of form, and the gradual modification throughout the series from one species to another has given rise to much speculation on their distribution into genera. In the subdivision of this family, the whole of which is included in the genus Venus of Linnaus, the first object has been to separate the fluviatile from the marine.

\section{CONCHACEA FLUVIATILIA.}

Testa epidermide crassî induta; cardine dentibus lateralibus instructo.

The fluviatile Conchacea are not very numerous in species; they inhabit rivers, lakes, ditches, fens, etc., and may be recognised as having their shell covered with a thick dark epidermis, generally much eroded towards the umbones. The hinge is characterized as having two or more distinct lateral teeth, which that of the marine Conchacea has not.

The Conchacea fluviatilia are divided into three genera, as follows:

Crclas.

Cyrena.

Galathea. 
CYCLAS, Bruguière.

Testa orato-globosa, acpuivalvis, subaruilateralis, tenuis, epidermide oliraceî induta; dentibus cardinalibus minimis in utrîque valvî̀ duobus, uno bifido; lateralibus in valvi altera binis, subelongatis, in alterit unatuor, duobus perexiguis. Ligamentum externum. Impressio muscularis pallii sinu nullo.

The genus Cyclas was instituted by 13ruguière for the reception of a small group of freshwater Tropiopoda, distributed by the early naturalists in the genera Tellina, Chama, dic. The Cyclades, however, then included the Cyrence, but Lamarck saw the propriety of separating them; and although De Blainville now holds to the original arrangement of Bruguière, he at one time arlopted the divisions of Lamarck as subgenera, under the titles of Corneo-Cyclas and Cyano-Cyclas.

The shell of Cyclas may be described as being ovately-globose, equivalve, and nearly cquilateral; it is moreover thin, and covered with an olivaceous cpidermis. There are two cardinal teeth in each ralre, one of which is bifid; with two lateral teeth in one valve, and four in the other, two of which are very small. The ligament is external, and there is no sinus in the muscular impression of the mantle.

Some of the Cyclades are furnished with an elongated siphon, and have been separated by Pfeiffer under the generic title of Pisidium.

\section{Excemple.}

PI. LXII. Fig. 1 to 3.

Crclas rivicola, Lamarck, Anim. sans vert., new edit., vol. vi. p. 267. Turton, Manual of British Shells, pl. 1. f. 1. Tellina cornea, Dillwyn.

Cyclas cornea, Draparnaud. 
CYCLAS.

Plate LIII.
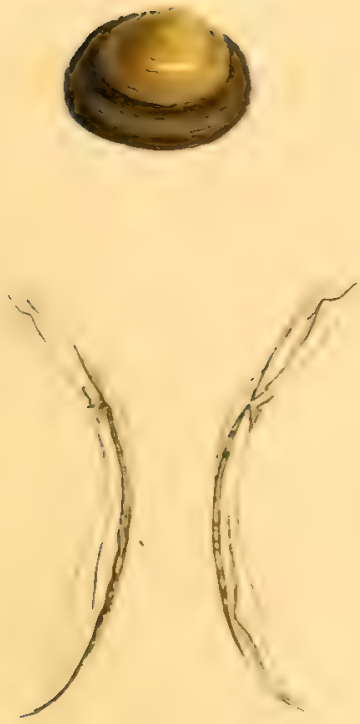

(1) 


CIRENA.

Plate LXIII.
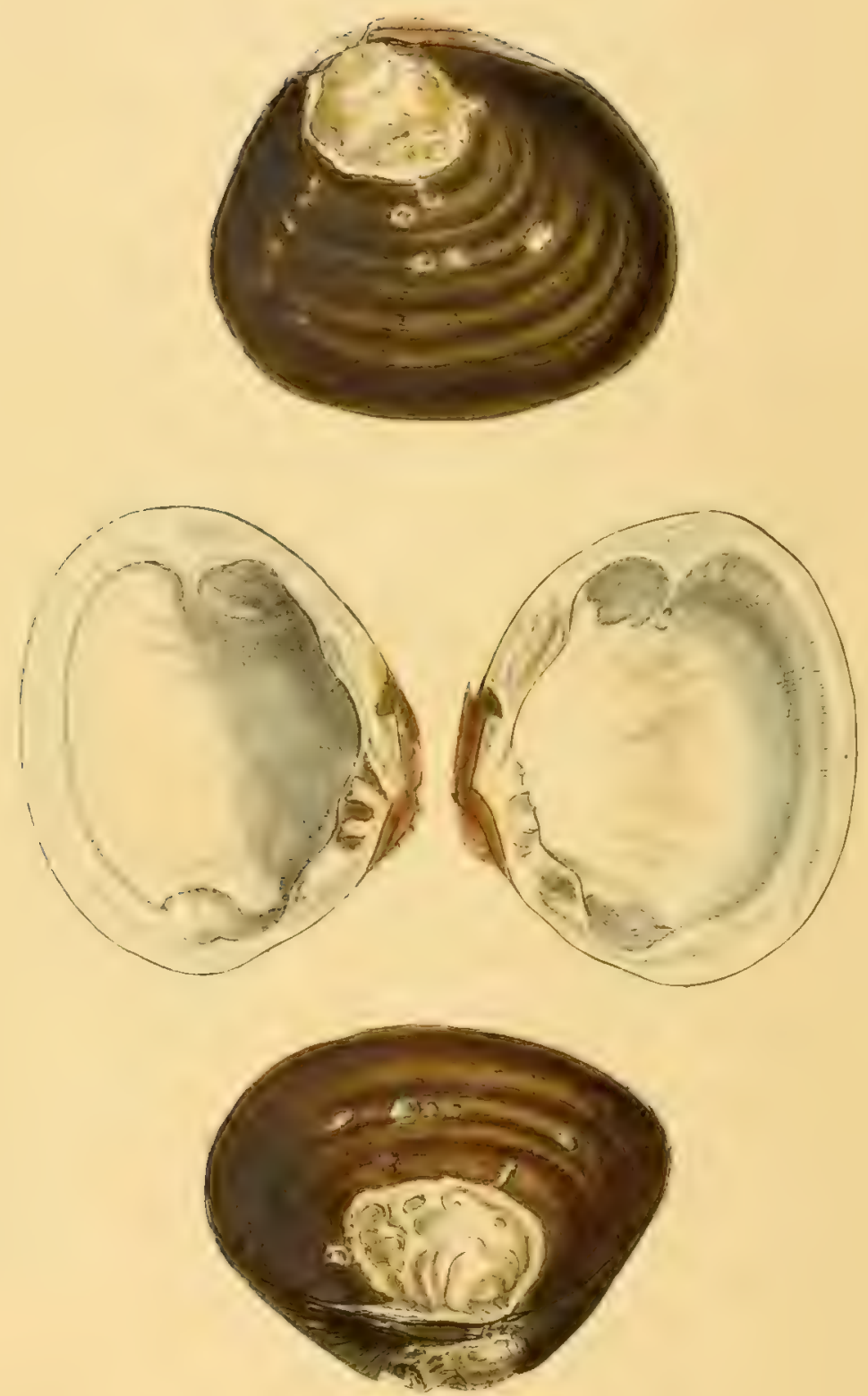

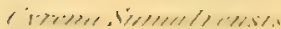


CYRENA, Lamarck.

Testa æquivalvis, æquilateralis, subventricosa, plerumque solida, epidermide fusco-olivaceit induta, umbonibus sxpè erosa. Dentes utriusque valva, cardinales tres, laterates duo, posticus ad cardinem propiùs admotus, anticus remotus. Ligamentum externum.

We have already shown that the species appropriated by Lamarck to the formation of this genus were included by Bruguière with the Cyclacles; we cannot but think, however, that they fully merit the distinction which is here assigned to them, though De Blainville now fails to acknowledge it. Their shells are always larger and thichcr than those of the former genus, are often much eroded, and differ in the number and position of the teeth.

The Cyrenæ may be described as haring an equivalve, equilateral shell, which is rather ventricose, generally solid, and covercd with an olive-brown or blackish epidermis. There are three cardinal and two lateral teeth in each valve, and of the latter one is situated near the linge, the other remote. The ligament is external.

Example.

PI. LXIII.

Cyrena Sumatrensis, Sowerby, Genera of Shells, No. 5. Deshayes, new edition of Lamarck, vol. vi. p. 277.

Cyclas Sumatrensis, De Blainville.

GALATHAA, Bruguière.

Testa trigonularis, æquivalvis, inæquilateralis, crassa, epidermide olivaceo-virente induta, umbonibus plerumque erosa. Dentes cardinales 
in valvâ alterâ duo, crassi, basi conniventes ; in alterâ tres, trianguli figuram formantes, intermedio minore, distincto. Dentes laterales remoti, ferè obsoleti. Ligamentum externum, breve, prominens, turgidum.

This genus was instituted by Bruguière for the reception of an interesting molluscum inhabiting the great rivers of Africa. De Blainville includes it with the rest of the fluviatile Conchacea in his grenus Cyclas; the propriety, however, of its separate arrangement has been fully established by the anatomical description of Rang.

The title of Galathiea, which was pre-oscupied in reference to a group of Crustuceu, has been altered by De Roissy to that of Egeria, by Bowditch to Megadesma, and by Sowerby to Potamophila ; we cannot, howerer, but sanction its adoption, as no one of the most obtuse perception could fail to distinguish a grenus of Crustacen from one of Tropiopodous Mollusca; although we must acknowledge, to the credit of these authors, that it is contrary to the strict rules of nomenclature.

The shell of Galathax may be described as being equivalve, inequilateral, and nearly triangular; the valves are thick and solid, of an opake marble white within, often tinged round the margin with blue, and they are covered externally with a thick, horny, olive-green epidermis, more or less ornamented with dark radiating lines, but generally much eroded. 'There are two thick cardinal teeth, united at the base, in one valve, and three, in the form of a triangle, in the other, the middle of which is smaller and isolated. The lateral teeth are remote and almost obsolete. The ligament is external, short, prominent and swollen.

\section{Example.}

PI. LXIV. Fig. 1 and 2.

Galathea radiata, Lamarck, Anim. sans vert., new edit., vol. vi. p. 284. Enc. Méth., pl. 250. f. 1.

Venus subviridis, Gmelin.

Venus paradoxa, Born. 


Tellina hermaphrodita, Dillwyn.

Egeria radiata, Roissy.

Megadesma radiatum, Bowditch.

Potamophila radiata, Sowerby.

Cyclas radiata, De Blainville.

\section{CONCHACEA MARINA.}

Testa epidermide rarò induta; cardine dente laterali unico instructo, sæpè nullo.

To say that there is no such thing in nature as a true species, but that a species is merely an artificial limit devised by the ingenuity of man to facilitate the systematic arrangement of created things, would be to make an assertion both dangerous and presuming. Yet, when we contemplate the immense series of marine Conchacea; when we examine the characters by which they have been subdivided, and observe how the relative value of these characters has disappeared through the discovery of the nicest intermediate modifications, we are lost in perplexity, and forced to acknowledge our embarrassment. The animal of the marine Conchacea is the same throughout, and on reference to its testaceous covering, we are scarcely able to detect any decided change of character. We must therefore trust to our description of the chief typical characters of the genera we have thought it most useful to select.

The shell of the marine Conchacea differs from that of the fluviatile in being mostly destitute of epidermis, and in having but one lateral tooth, often none; the cardinal teeth are the same. They are divided into five genera, as follows :

Cyprina.

Astarte.

VENUS.
Cytherea.

Pullastra.

VOL. I. 


\section{CYPRINA, Lamarck.}

Testa equnivalvis, indepulateralis, obliqui cordata, umbonibus obliqui curvis; epidermide fuscâ induta. Dentes carcinales tres, ad basem appropinquantes, supernè divaricati. Dens lateralis posticus, a cardine remotus. Ligamentum externum, in sinu marginali partin immersum.

This genus may be said to partake of the characters of Cyrena and Venus, thus serving to establish a close affinity between the fluviatile and marine Conchacea. It has comparatively a lange shell, which may be ensily recognised by its thick fibrous epidermis.

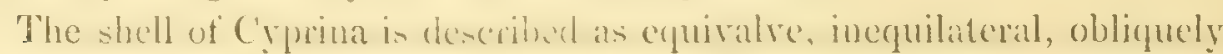
cordate, with the umbones obliguely curved. There are three uncepal cardinal feeth, approximatine at the hase, and diverging a little superiorly; and there is a postcrior lateral tooth at some distanco from the hinge. The ligament is external, parily hureel in a deep matrinal sinus. The Cyprina mostly inhabit the North Seas.

\section{Example.}

P. LXV. Fig. 1 and 2.

Cyprina vulgaris, Sowerby, Genera of Shells, No. 32. Enc. Méth., pl. 301. f. 1.

Venus Islandica, Linnzus.

Cyprina Islandica, Lamarck.

$$
\text { ASTARTE, Sowerby. }
$$

Testa suborbiculata, plerumque transversa, arquiralvis, inaquilateralis, epidermide fuscâ induta. Cardo dentibus duobus, validis, divari- 
CYPRINA.

Plate LXV.

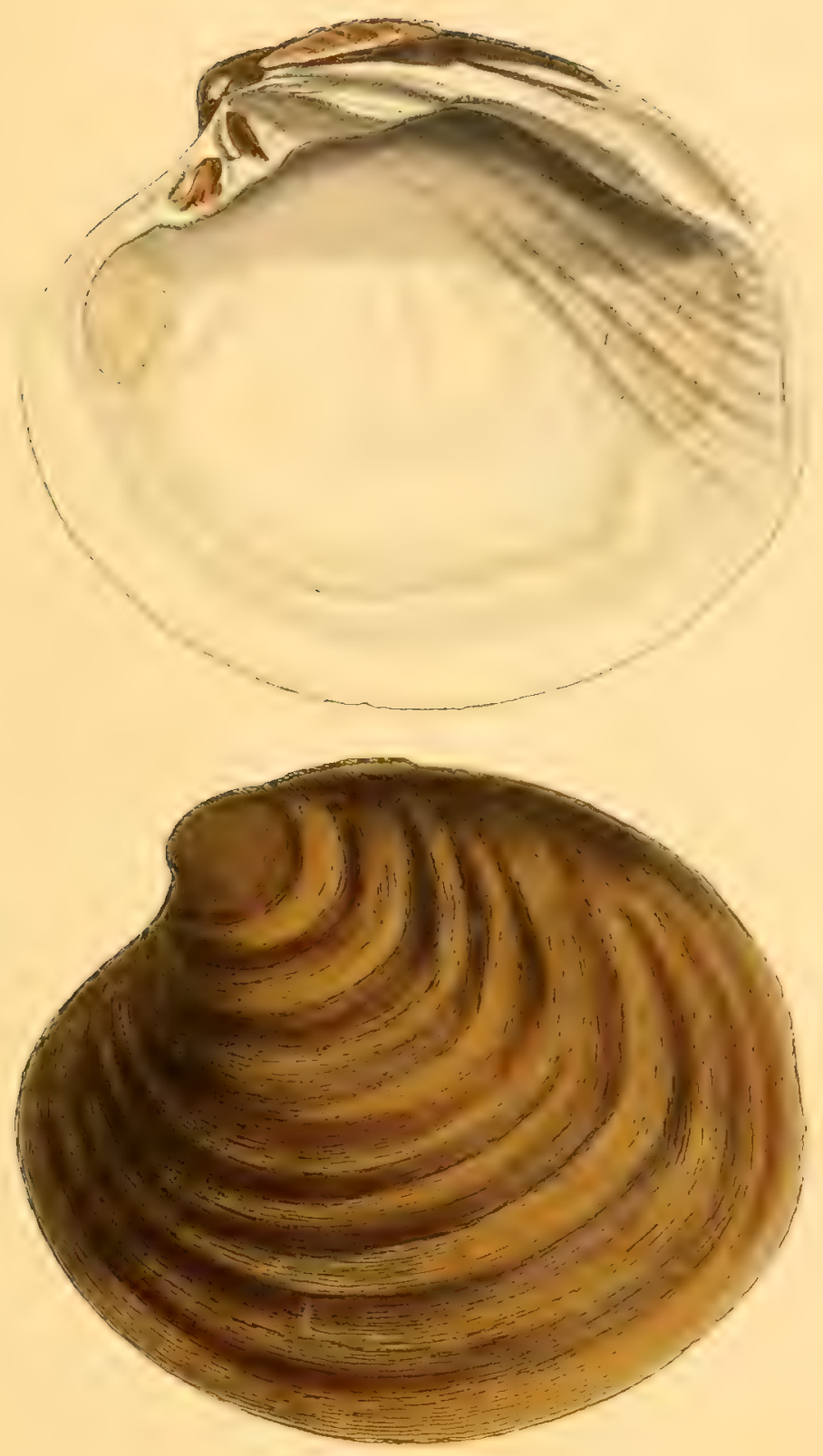

ripuiver velforlis: 


ASTARTE.

Plate LXVI.
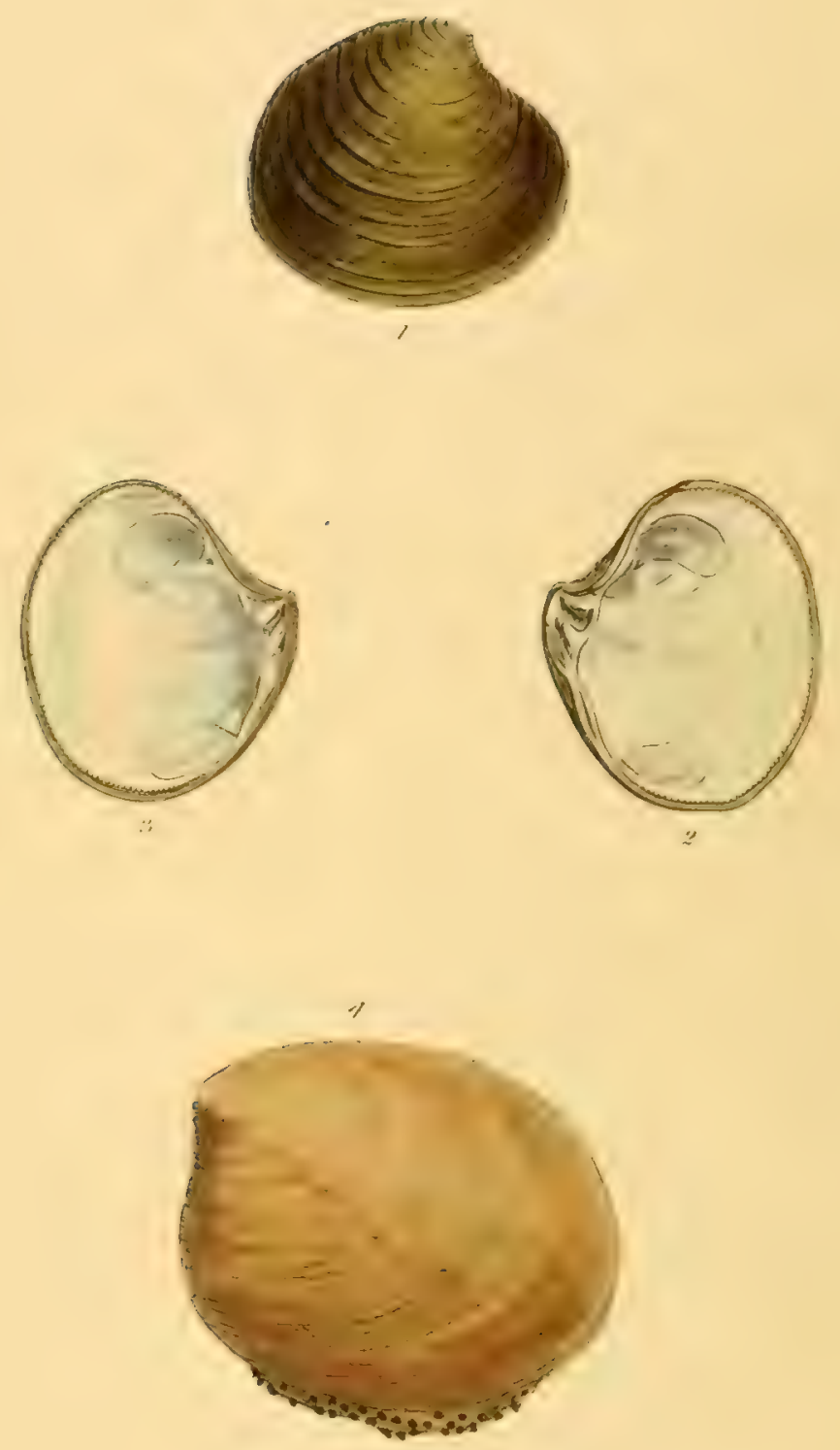

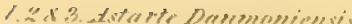

4.............enerertiolar? 
catis, in valvì dextrâ; dentibus, altero distincto, altero obsoleto, in sinistrâ. Impressiones musculares dua, quorum una bipartita.

Sowerby was the first to introduce this genus under the above title; Lamarck afterwards described it under that of Crassina; the former therefore has the priority. The latter author placed it, though not without some indecision, in his family of the Nymphacea; but upon noting the affinity of the shell of Astarte with that of Cyprinat and Vemus, the propriety of its removal to the family of the Conchacea will be readily admitted.

The shell of Astarte may be described as being nearly orbicular but somewhat transverse, equivalve, inequilateral, and covered with a brown epidernis. The hinge consists of two divergent teeth in the right valve; with one distinct and one obsolete tooth in the left. One of the muscular impressions is bipartite, and the ligament is external.

\section{Excomple.}

PI. LXVI. Fig. 1 to 3.

Astarte Damnoniensis, Sowerby, Genera of Shells, No. 4.

Venus Damnoniensis, Montague.

Venus crassatella, De Blainville.

Crassina Damnoniensis, Lamarck.

VENUS, Linnæus.

Testa requivalvis, inæquilateralis, suborbicularis, subglobosa, extus plerumque rugosa, rarò lavis, undiquè clausa. Dentes cardinales plerumque tres in utrâque valvâ ab umbone divaricati, interdum contigui. Impressio muscularis pallii sinu mediocri. Ligamentum externum.

The Linnæan Veneres have been variously distributed; and although N 2 
Deshayes and De Blainville still fail to acknowled re some of the genera that Lamarck thought it necessary to institute, it cannot be denied but that a free subdivision of so extensive a series is advantageous, where it can be effected with tolerable accuracy. We have therefore adopted the Veneres of Lamarck, with the exception of certain species removed by Sowerby, to form, together with the Lamarckian Venerupes, his new genus Pullestra (vide p. 95); thus we include only such as are characterized by having a suborbicular globose shell, with generally three divergent cardinal teeth in each valve.

The shell of Venus is described as being equivalve, inequilateral, nearly orbicular, subglobose, generally rough on the outside, and everywhere closely shut. There are mostly three cardinal teeth in each valve, sometimes contiguous, diverging from the umbo. The muscular impression of the mantle has a moderate sinus, and the ligament is external.

\section{Examples.}

Pl. LXVII. Fig. 1.

Venes puerpera, Linneus, Mantissa, p. 545. Lamarck, Anim. Sims vert., new edit., vol. vi. p. 333.

Venus reticulata, var., Dillwyn.

Pl. LXVII. Fig. 2.

Venus subrugosa, Sowerby, Genera of Shells, No. 41.

Pl. LXVII. Fig. 3.

Venus thiara, Dillwyn, Catalogue, vol. i. p. 162. Lamarck, Anim. sans vert., new edit., vol. vi. p. 372. Enc. Méth., pl. 275. f. 4.

PI. LXVIII. Fig. 1.

Venus paphia, Linnæeus, Syst. Nat., p. 1129. Lamarck, Anim. sans vert., new edit., vol. vi. p. 371. Enc. Méth., pl. 275. f. 5.

Pl. LXVIII. Fig. 2.

Venus cancellata, Linnæus, Syst. Nat., edit. 12. p. 1130. Lamarck, 
VENUS.

Plate LIVII.
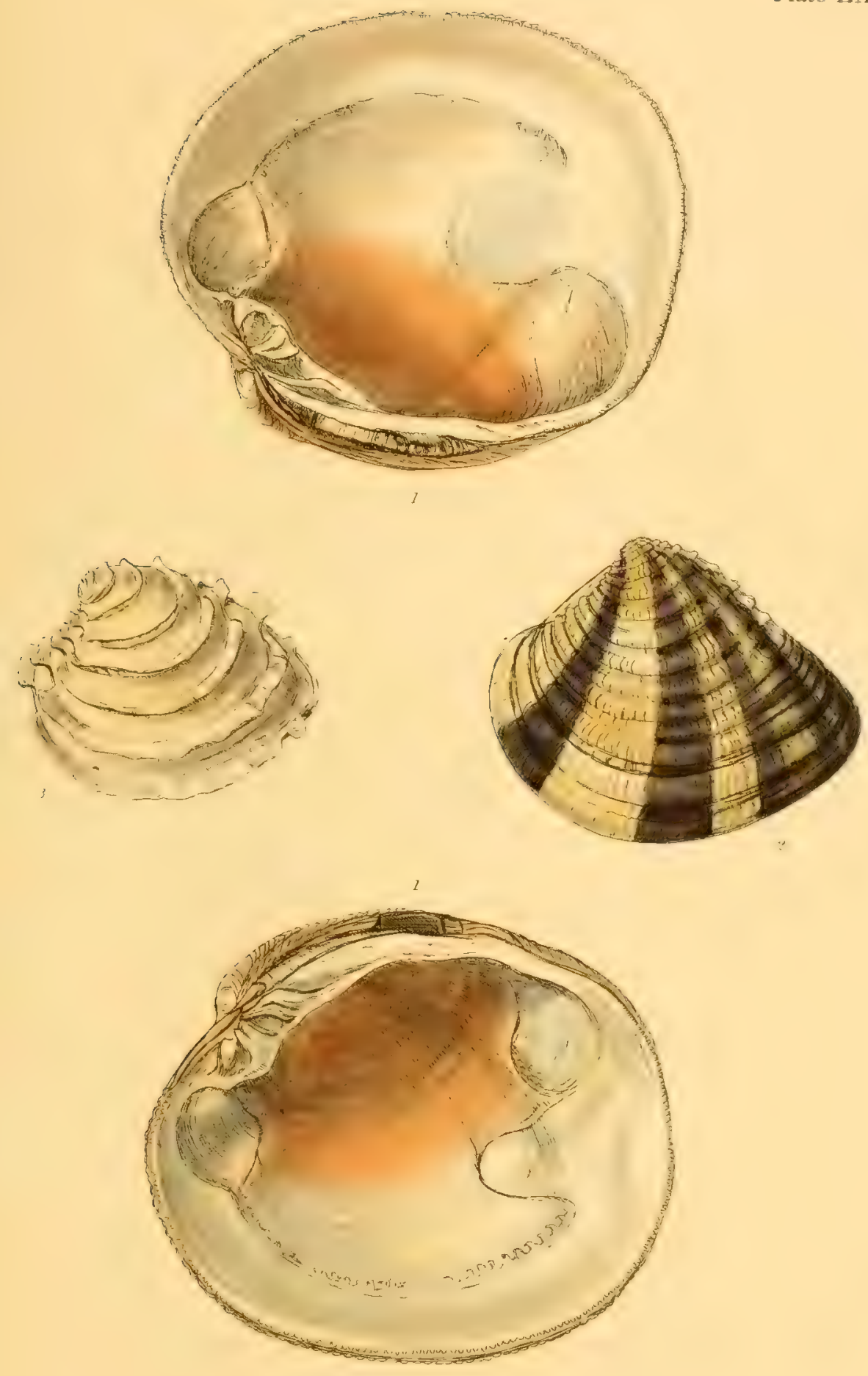

Fig. 2. Tenus puerpern.
3......... subrugosa.
Thialu. 

TENTS

Plate LXVIII.
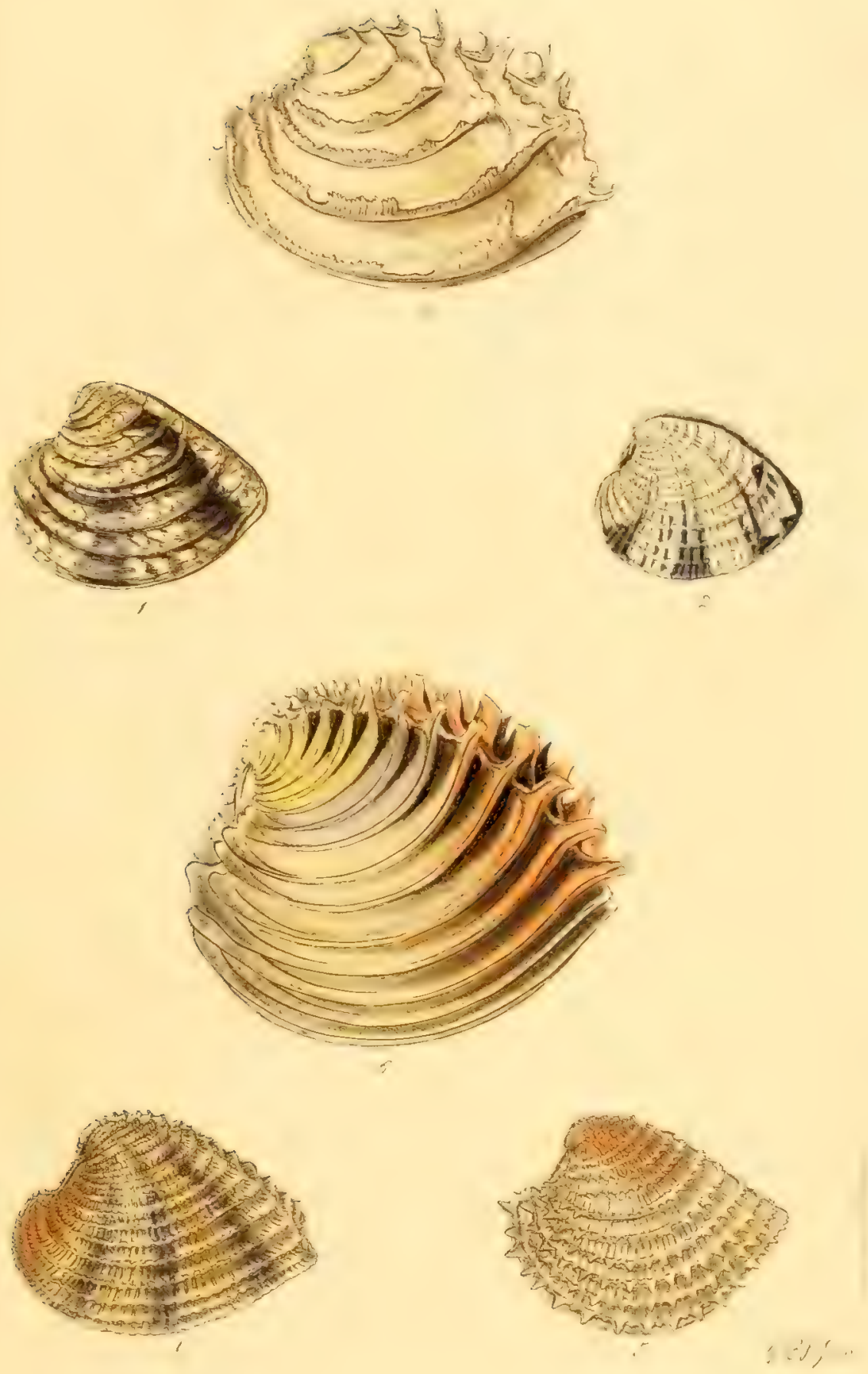

Anim. sans vert., new edit., vol. vi. p. 343. Enc. Méth., pl. 268. f. 1. $a, b$.

\section{PI. LXVIII. Fig. 3.}

Venus lamellata, Lamarck, Anim. sans vert., new edit., vol. vi. p. 349.

\section{Pl. LXVIII. Fig. 4.}

Venus subrostrata, Lamarck, Anim. sans vert, new edit, vol. vi. p. 343. Enc. Méth., pl. 267. f. 7.

\section{PI. LXVIII. Fig. 5.}

Venus gnidia, Broderip and Sowerby, Zool. Journ., vol. iv. p. 364.

Pl. LXVIII. Fig. 6.

Yenus plicata, Gmelin, p. 3276. No. 30. Lamarck, Anim. sans vert., new edit., vol. vi. p. 341. Enc. Méth., pl. 275. f. 3. $a, b$.

\section{CYTHEREA, Lamarck.}

Testa æquivalvis, inæquilateralis, suborbicularis, transversa vel trigona, extùs aut læevis aut rugosa; dentibus in valvâ alterâ tribus cardinalibus, divaricatis, cum foveâ remotiusculâ, margini parallelâ; in alterâ quatuor, quorum unico divergente, remotiusculo, quasi laterali, in foveâ valvæ oppositie inserto. Impressio muscularis pallii plerumque sinu. Ligamentum elongatum, externum.

We have thought it useful to continue the genus Cytherea of Lamarck, although it must be confessed that the lateral or laterally diverging cardinal tooth, the only character by which its shell is said to differ from that of V'emus, is sometimes almost obsolete. Lamaick himself, indeed, appears to have been involved in some confusion; for although the two genera may be decided with tolerable accuracy, there are many of his 
Cytherex which might have remained with more propriety among the Veneres. The Cytherea concentrica and its cognate species have been separated by Poli under the generic title of Artemis.

The shell of Cytherea is described as being equivalve, inequilateral, suborbicular, transverse or triangular, and either smooth or rough on the outside. There are three divaricate cardinal teeth in one valve, with a rather remote pit running parallel with the marein; and four in the other, one of which is remote, diverging litterally, almost sufticiently so to be considered as a lateral tooth, and is inserted in the pit of the opposite valve. The muscular impression of the mantle appears to be either with or withoat a simus, and the ligannent is clongated and extemal.

\section{Exumples.}

Pl. LXIX. and LXX. Fig. 1.

Cytherea petechialis, Lamarck, Anim. sans vert., new edit, vol. vi. p. 299. Enc. Méth., pl. 268, f. 5 and 6.

\section{P1. LXIX. Fig. 2.}

Cytherea planulata, Sowerby, Proceedings Zool. Soc., 1835, p. 46 ; Genera of Shells, No. 33.

Pl. LXIX. Fig. 3.

Cytherea aurantiaca, Sowerby, Genera of Shells, No. 33.

\section{Pl. LXX. Fig. 4.}

Cytherea concentrica, Lamarck, Anim. sans vert, new edit., vol. vi. p. 316. Enc. Méth., pl. 279. f. 2, $a, b$. Venus concentrica, Linnæus.

Artemis concentrica, Poli.

\section{Pl. LXX. Fig. 5.}

Cytierea gibbia, Lamarck, Anim. sans vert, new edit, vol. vi. p. 323. Enc. Méth., pl. 271. f. 4, $a, b$. 


$$
00
$$



CYTHEREA.

Plate LXI.

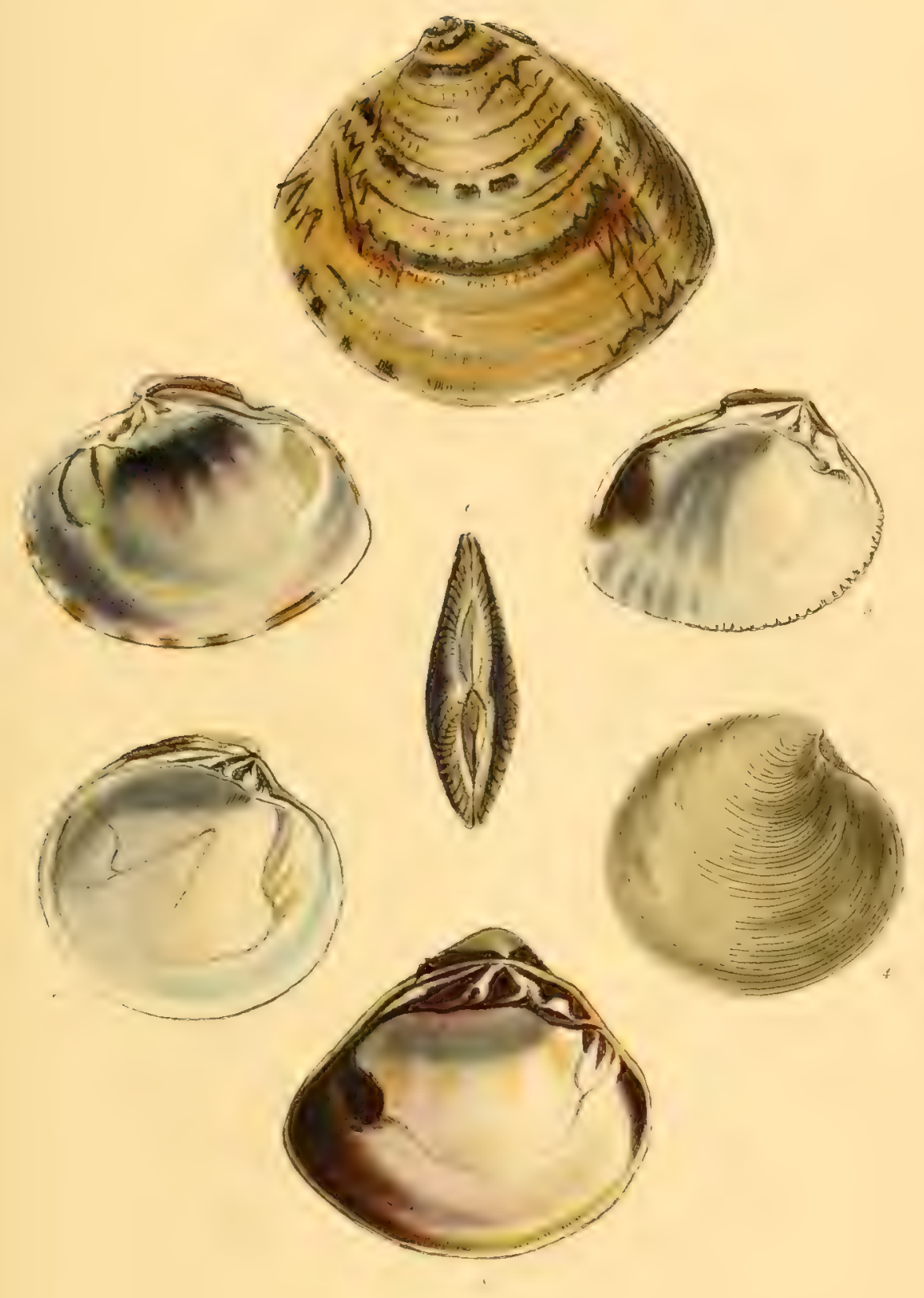



CY'THEREA.

Plate LXXI.
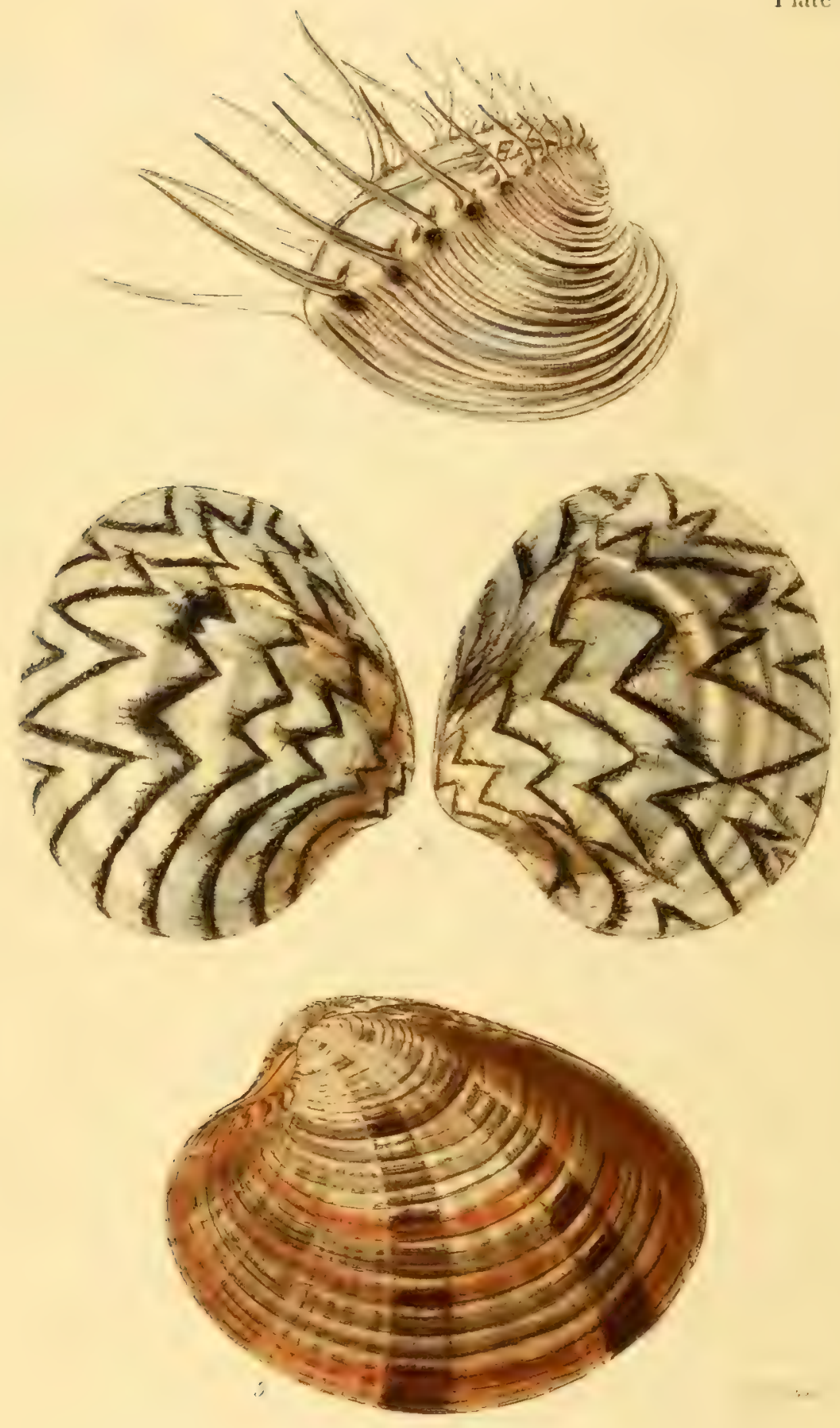
Pl. LXX. Fig. 6.

Crtherea Meroe, Sowerby, Genera of Shells, No. 33. Sowerby, Jun., Conch. Manual, f. 117, $a$.

Meroë picta, Schumacher.

\section{PI. LXXI. Fig. 1.*}

Cytherea dione, Lamarck, Anim. sans vert., new edit., vol. vi. p. 312. Enc. Méth., pl. 275. f. ], $a, b$.

Venus dione, Linnæus.

\section{Pl. LXXI. Fig. 2.*}

Cytherea castrensis, Lamarck, Anim. sans vert, nerv edit, vol. vi. p. 308. Enc. Méth., pl. 273. f. 1, $\alpha, b$.

Venus castrensis, Linnæus.

\section{Pl. LXXI. Fig. 3.}

Cytherea erycina, Lamarck, Anim. sans vert., new edit, vol. vi. p. 303.

Enc. Méth., pl. 264. f. 2, $a$, , .

Venus erycina, Linnæus.

\section{PULLASTRA, Sowerby.}

Testa æequivalvis, transversa, inæu uilateralis, latere antico breviore. Dentes cardinales tres, contigui, in utrâque valvâ, ad apicem interdum paululum emarginati; laterales nulli. Impressio muscularis pallii sinu magno. Ligamentum externum in foveâ elongatâ marginali partim occultatum.

The genus Pullastra was instituted by Sowerby for the purpose of associating a very natural and well-defined group of Conchncea, consisting of the Tenerupes and some of the Ieneres of Lanarck. The former of these were placed by Lamarck in the family of the Lithophagu, but it has been

* Our figures of these species are drawn from two magnificent specimens in the possession of Sigismund Rucker, Esq. 
asserted by Sowerby, that, although often found living in cavities of rocks, the Tenerupes are evidently not terebrating animals, like the Saxicava and Petricola; their places of habitation being rather the result of accident. Their affinity with the Vemus pullastra of Lamarck, and its cognate species, is now clearly established.

The shell of Pullastra is described as being equivalve, transverse and inequilateral, much shorter on the anterior side. There are three contigruous cardinal teeth, sometimes a little emarginated at the point, in each valve, but no lateral teeth. The muscular impression of the mantle has a large sinus; and the ligament is external, partially concealed within an elongated marginal pit.

Examples.

P1. LXXII. Fig. 1.

Puliastra vulgaris, Sowerby, Genera of Shells, No. 28. Venus textile, Gmelin. Lamarck.

Pl. LXXII. Fig. 2.

Pullastra literata, Sowerby, Genera of Shells, No. 28.

Venus literata, Linnæus. Lamarck.

Pl. LXXII. Fig. 3.

Pullastra papilionacea, Sowerby, Genera of Shells, No. 28.

Venus papilionacea, Lamarck.

Venus rotundata, Linnæus.

\section{Family 9. CARDIACEA.}

Testa æquivalvis, cordiformis vel transversa, interdum subhians; sæpissimè costis ab umbonibus ad marginem divergentibus. Dentes cardinales plerumque duo, vel in formâ vel in situ irregulares. Dentes laterales aut duo, aut unicus, aut nullus. 
PULLASTIRA.

Plate LXXII.
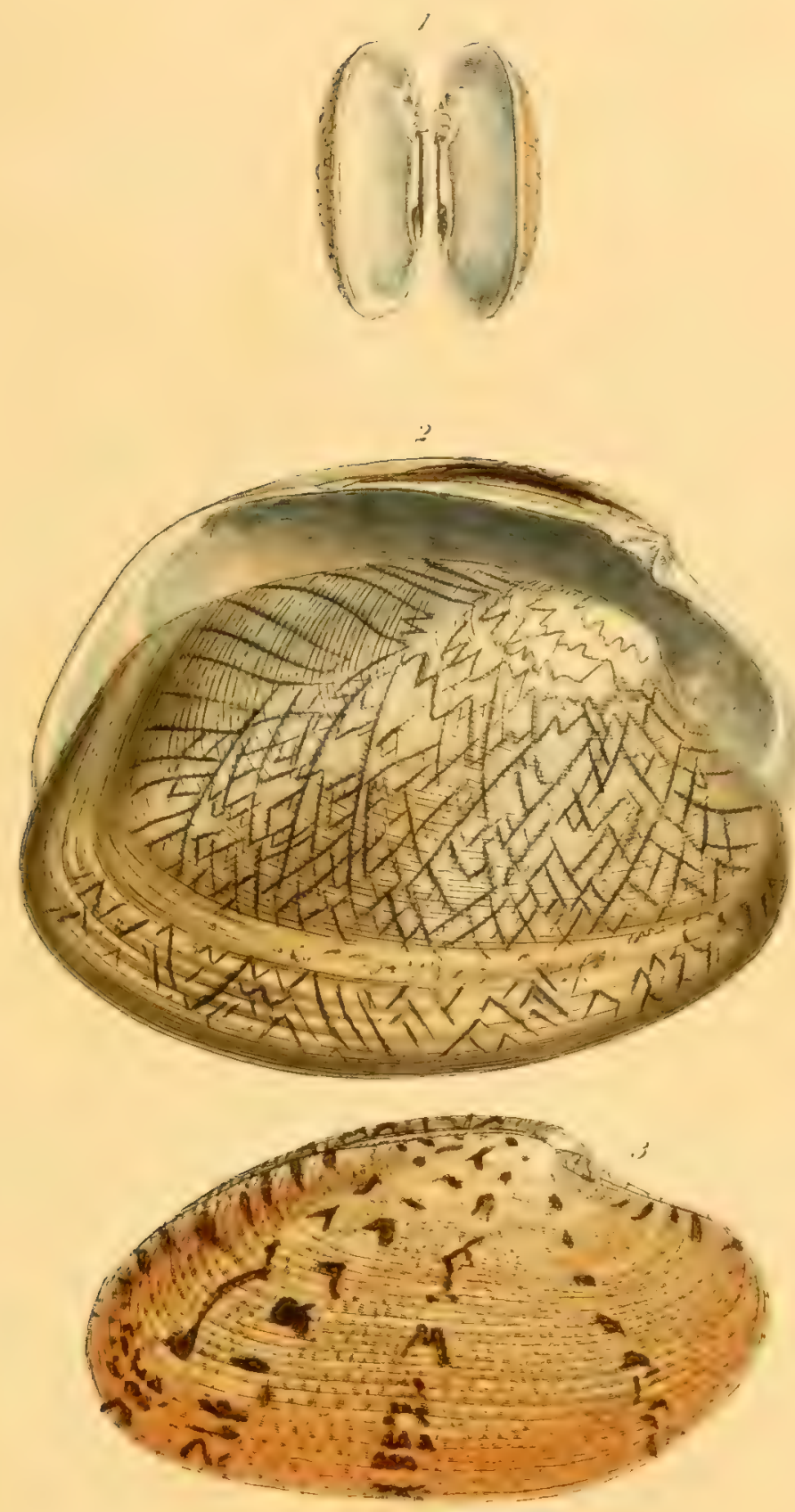

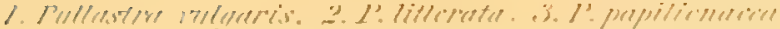



The Cardiacen constitute a very natural group, although there are two genera, Cardita and Cypricardia, which we have not included without some hesitation, on account of their affinity with the Chamacea. The shell of the Cardiacea is however somewhat peculiar in its characters, and may be easily recognised. It is described as being equivalve, cordiform or transverse, sometimes a little gaping; and the valves are mostly characterized by being disposed in longitudinal ribs diverging in symmetrical order from the umbones to the margin. There are generally two cardinal teeth, irregular both in their form and situation; and one or two lateral teeth, but sometimes none. The family is divided into four genera, as follows:
Cardium.
Cardita.
ISOCARDIA.
Cypricardia.

\section{CARDIUM, Linnæus.}

Testa requivalvis, subinæquilateralis, subcordata, interdum posticè hians; sappissimè costis ab umbonibus ad marginen symmetricè divergentibus; marginibus valvarum crenulatis, interdentatis. Cardo, dentibus in utràque valvâ duobus approximatis, obliquis, confertim intersertis; lateralibus duobus remotis. Impressio muscularis pallii integra. Ligamentum externum.

The genus Cardium remains nearly as entire as in the time of Linnæus, and is very numerous in species. The common Cockle, Cardium edule, may be taken as the type of the series, their shells throughout being of a more or less globular cordate form.

The shell of Cardium is described as being equivalve, rather inequilateral, more or less heart-shaped, and sometimes gaping on the posterior side; the valves are generally ribbed longitudinally, and the ribs, which diverge in symmetrical order from the umbones to the margin, are often

VOL. I. 
covered with sharp spines or tubercles; the margins of the valves are crenulated, interclosing with each other. The hinge consists of two oblique approximate teeth in each valve, closely interlocking with each other; and there are also two remote lateral teeth. The muscular impression of the mantle is entire, and the ligament is external.

We have selected the following five-and-twenty species of this benutiful genus, in order that its varieties may be fully illustrated.

\section{Examples.}

Pl. LXXIII. Fig. 1, $1^{*}$ and $1^{* * *}$.

Cardium cardissa, Linnæus, Syst. Nat., p. 1121 . Lamarck, Anim. sans vert., new edit., vol. vi. p. 411 . Enc. Méth., pl. 293. f. 3.

Pl. LXXIII. Fig. 2.

Cardum bringugatum, Broderip and Sowerby, Zool. Journ., iv. p. 367.

Pl. LXXIII. Fig, 3.

Cardium elatum, Sowerby, Proceedings Zool. Soc., 1833, p. 84.

Pl. LXXIII. Fig. 4.

Cardium obovale, Sowerby, Proceedings Zool. Soc., 1833, p. 84.

Pl. LXXIV. Fig. 5.

Cardiun Cumingit, Sowerby, Proceedings Zool. Soc., 1833, p. 82.

Pl. LXXIV. Fig. 6.

Cardiun mpolitum, Sowerby, Jun., Proceedings Zool. Soc., 1840, p. 107.

\section{Pl. LXXIV. Fig. 7.}

Cardiun puxctulatum, Broderip and Sowerby, Zool. Journ., iv. p. 366.

PI. LXXXIV. Fig. 8.

Candiuar consors, Sowerby, Proceedings Zool. Soc., 1833, p. 85. 
CARDIUM.

Plate LXXIII.
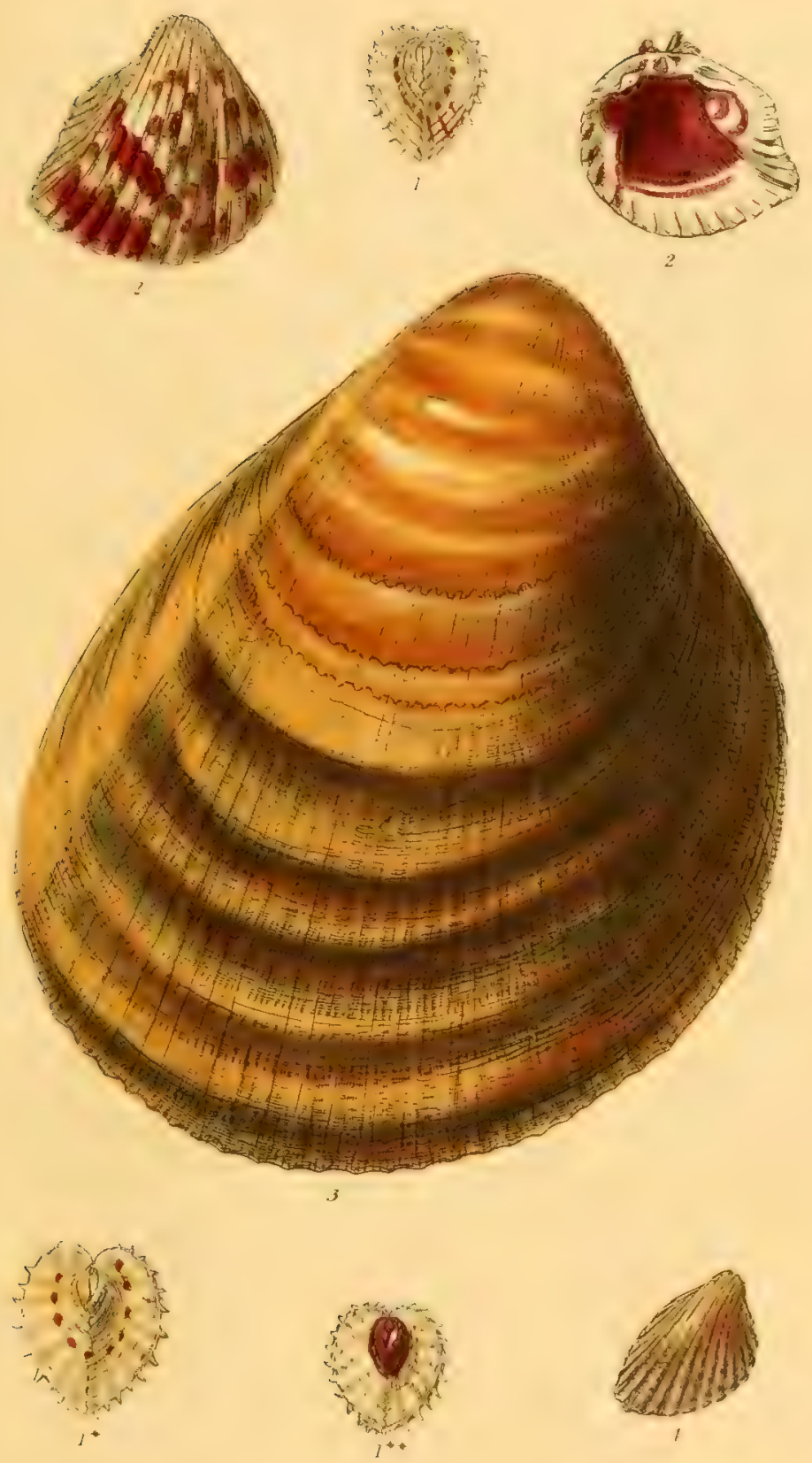

CARDIUM.

Plate LXXIV.
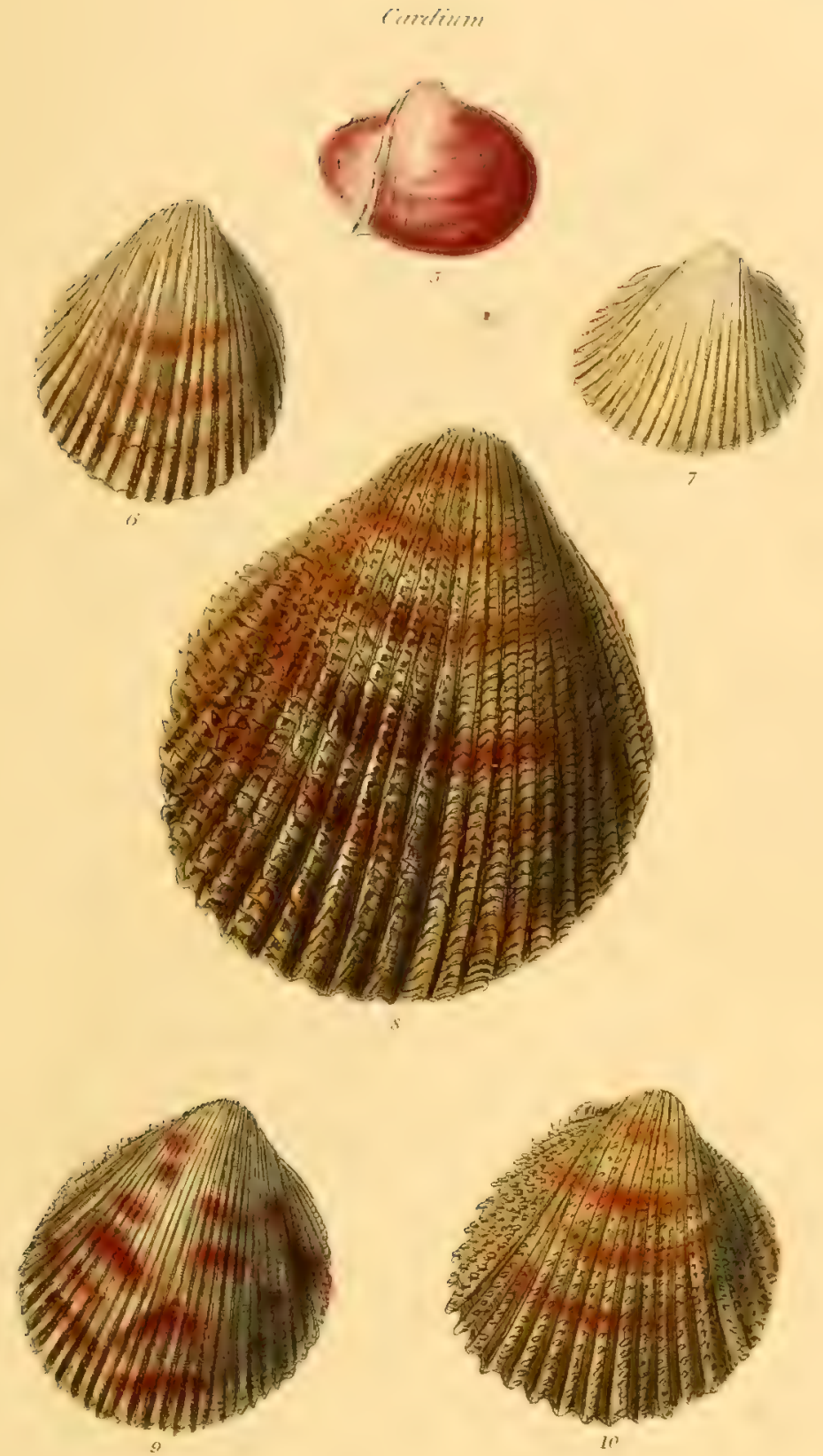


CARDIUM.

Plate LXXY.'
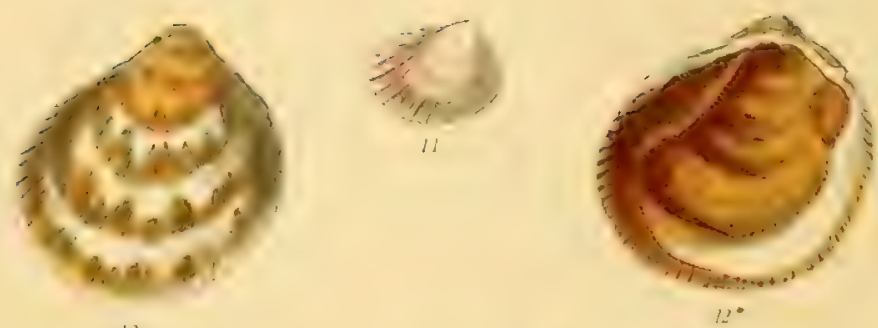

1)
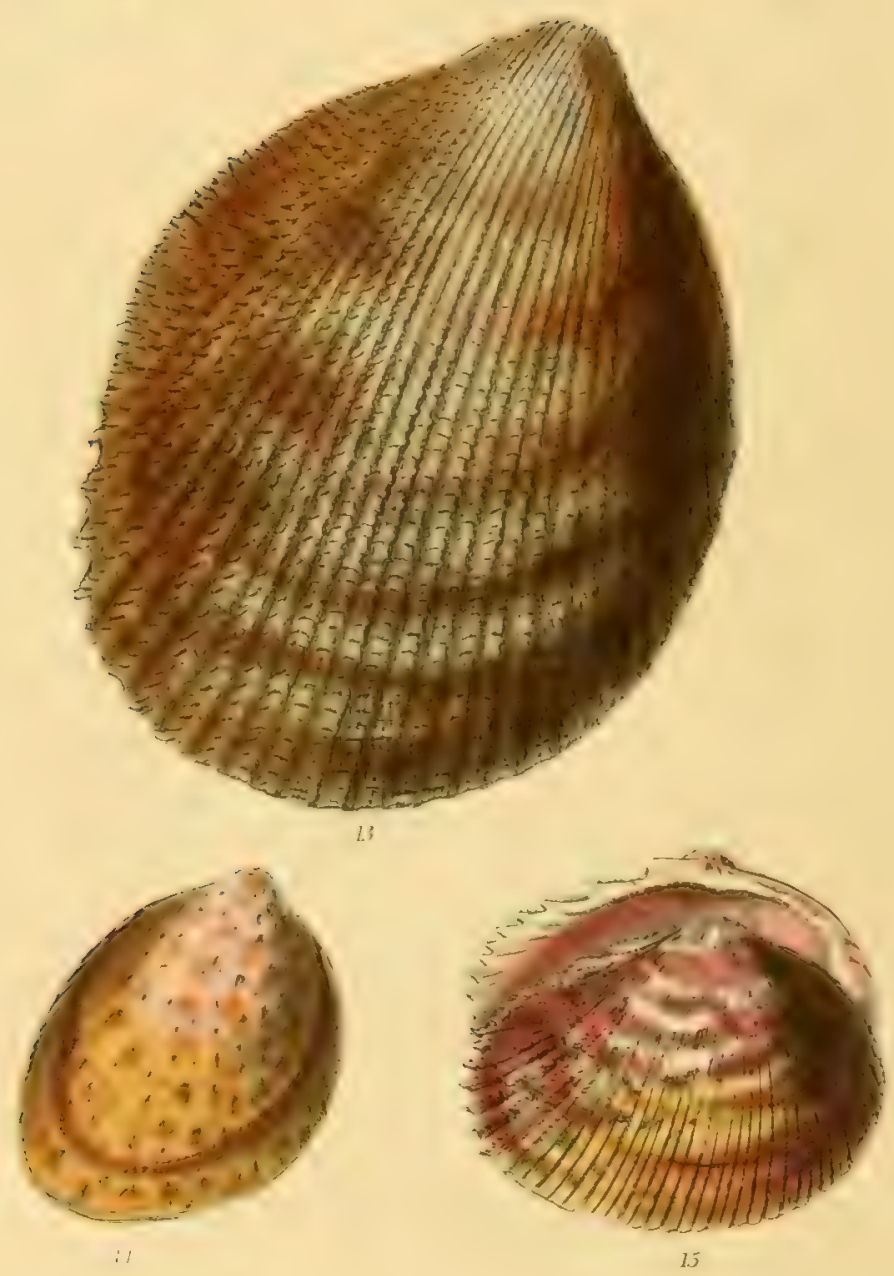

CARDIUM.

late LXX Vl.
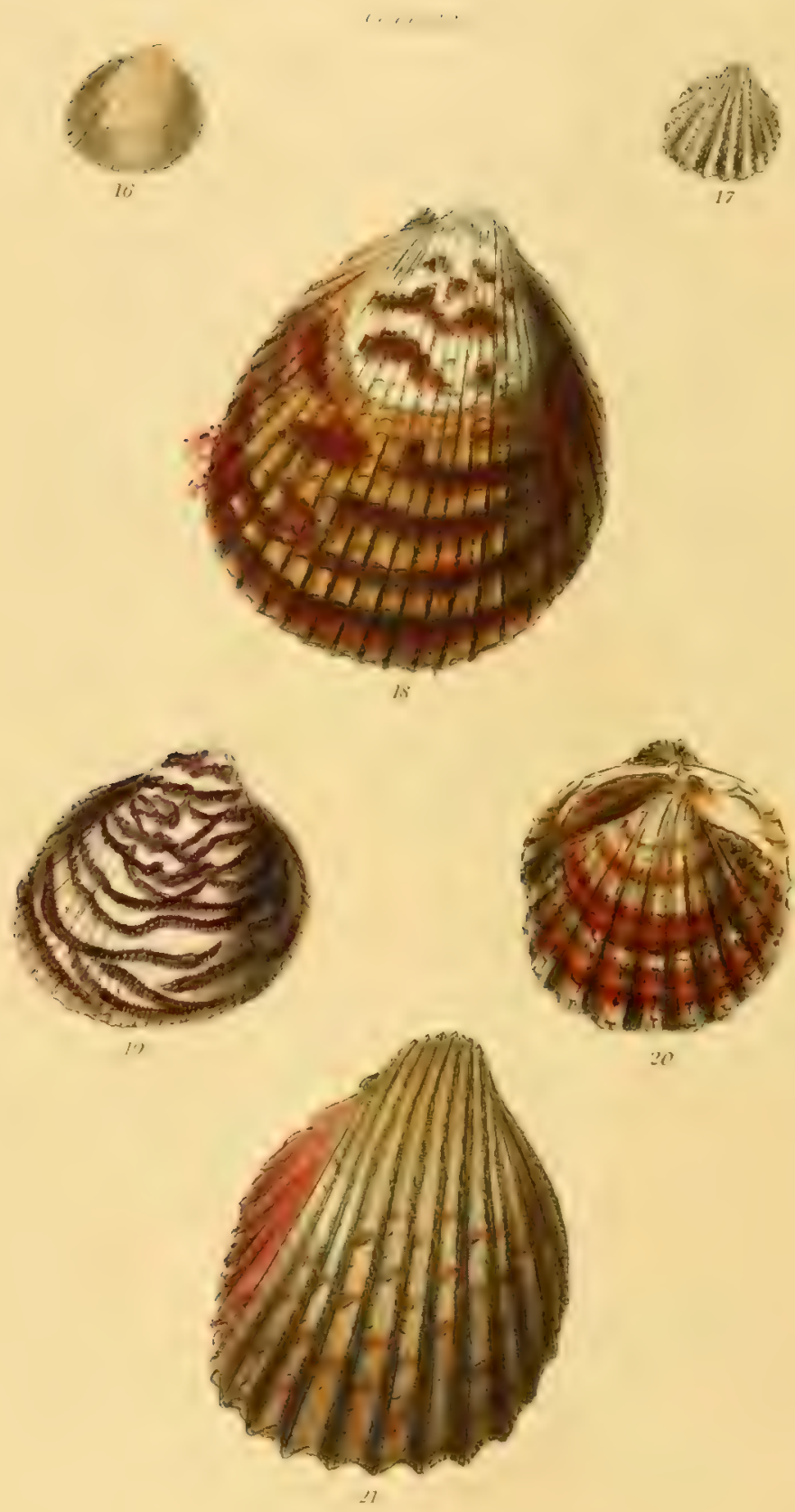

30 
Pl. LXXIV. Fig. 9.

Cardicm oxygonum, Somerby, Jun., Procecdings Zool. Soc, 1840, p. 107.

Pl. LXXIV. Fig. 10.

Cardium senticosum, Sowerby, Proceedings Zool. Soc., 1833, p. 84.

Pl. LXXV. Fig. 11.

Cardium ringiculum, Sowerby, Jun., Proceedings Zool. Soc., 1840, p. 106.

PI. LXXV. Fig. 12 and 12*.

Cardium australe, Sowerby, Jun., Proceedings Zool. Soc., 1840, p. 105.

Cardium sauciatum, Beck.

Pl. LXXV. Fig. 13.

Cardium orbita, Sowerby, Proceedings Zool. Soc., 1833, p. 85.

Pl. LXXV. Fig. 14.

Cardium multipunctatun, Sowerby, Proceedings Zool. Soc., 1833 , p. 84 .

Pl. LXXV. Fig. 15.

Cardium aspersum, Sowerby, Proceedings Zool. Soc., 1833, p. 85.

Pl. LXXVI. Fig. 16.

Cardicui striatulum, Somerby, Jun., Proceedings Zool. Soc., 1840, p. 105.

Pl. LXXVI. Fig. 17.

Cardium graniferum, Broderip and Sowerby, Zool. Journ., iv. p. 367.

Pl. LXXVI. Fig. 18.

Cardium maculatum, Sorverby, Proceedings Zool. Soc., 1833, p. 85.

02 
Pl. LXXVI. Fig. 19.

Cardiun tenuicostatum, Lamarck, Anim. sans vert., new edit., vol. vi. p. 392.

Pl. LXXVI. Fig. 20.

Cardium paucicostatui, Sowerby, Jun., Proceedings Zool. Soc., 1840 , p. 106.

1'. LXXVI. Fig. 21.

Candich Panamense, Sowerby, Proceedings Zool. Soc., 1833, p. 83.

PI. LXXVII. Fig. 22.

Cardum tumoriferum, Lamarck, Anim. sans vert., new edit, vol. vi. p. 410.

Pl. LXXVII. Fig. 23.

Cardium procerca, Sowerby, Proceedings Zool. Soc., 1833, p. 83.

Pl. LXXVII. Fig. 24.

Cardium subrexcsum, Sowerby, Jun., Proceedings Zool. Soc., 1840 , p. 110.

Pl. LXXVII. Fig. 25.

Cardicu planicostatun, Sowerby, Proccedings Zool. Soc., 1833, p. 83.

ISOCARDIA, Lamarck.

T'esta xquivalvis, cordata, ventricosa; umbonibus distantibus, divaricatis, involutis. Dentes cardinales duo compressi, uno sub umbone recurvo; dente laterali antico, elongato. Impressio muscularis pallii simplex. Ligamentum externum.

The cordate symmetry of form which distinguishes the shell of Isocardia, as well as the elegant incurvature of the umbones, render it emi- 
CARDIUM.

Plate LXXVII.

firmfium
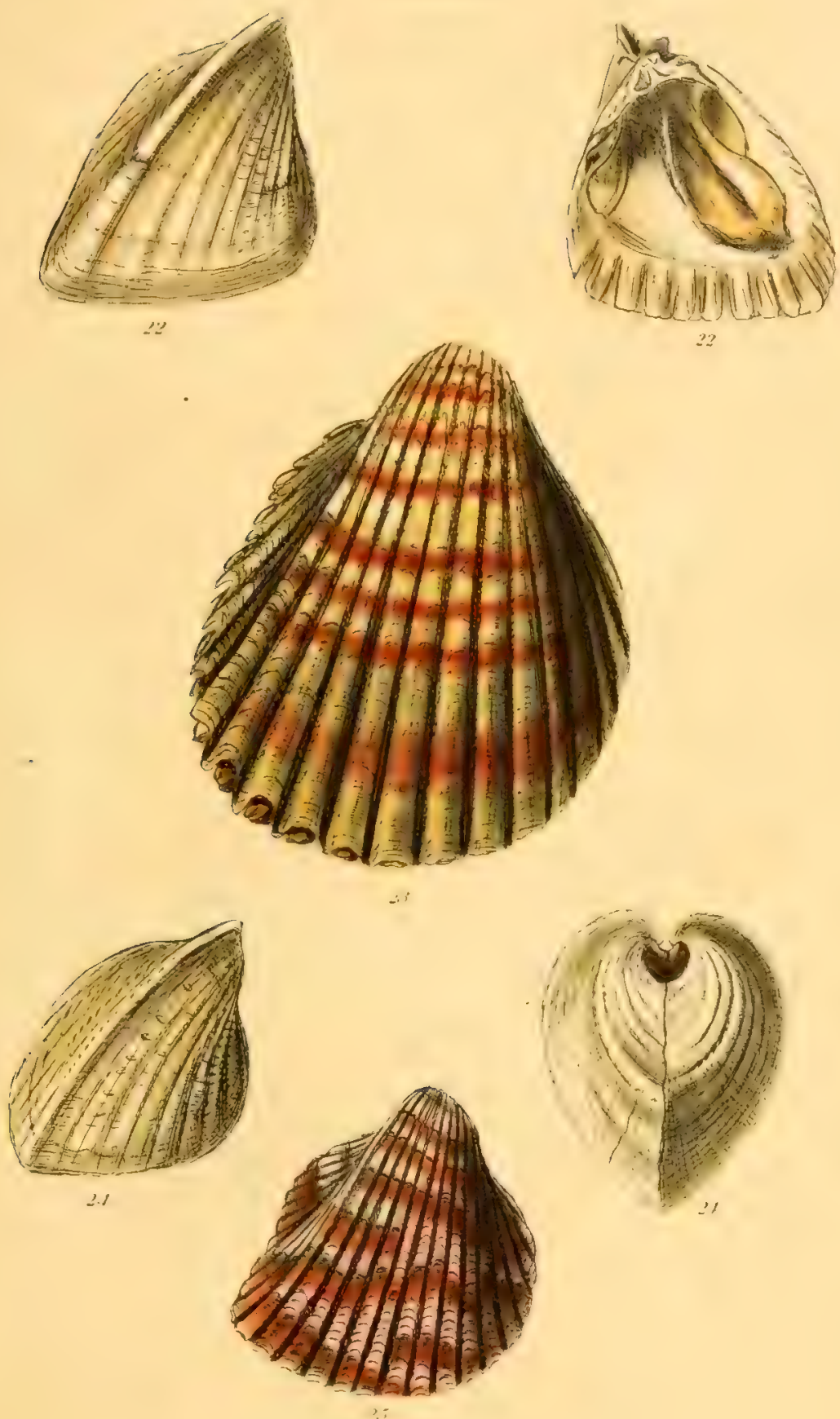


Plate LXXYIII.

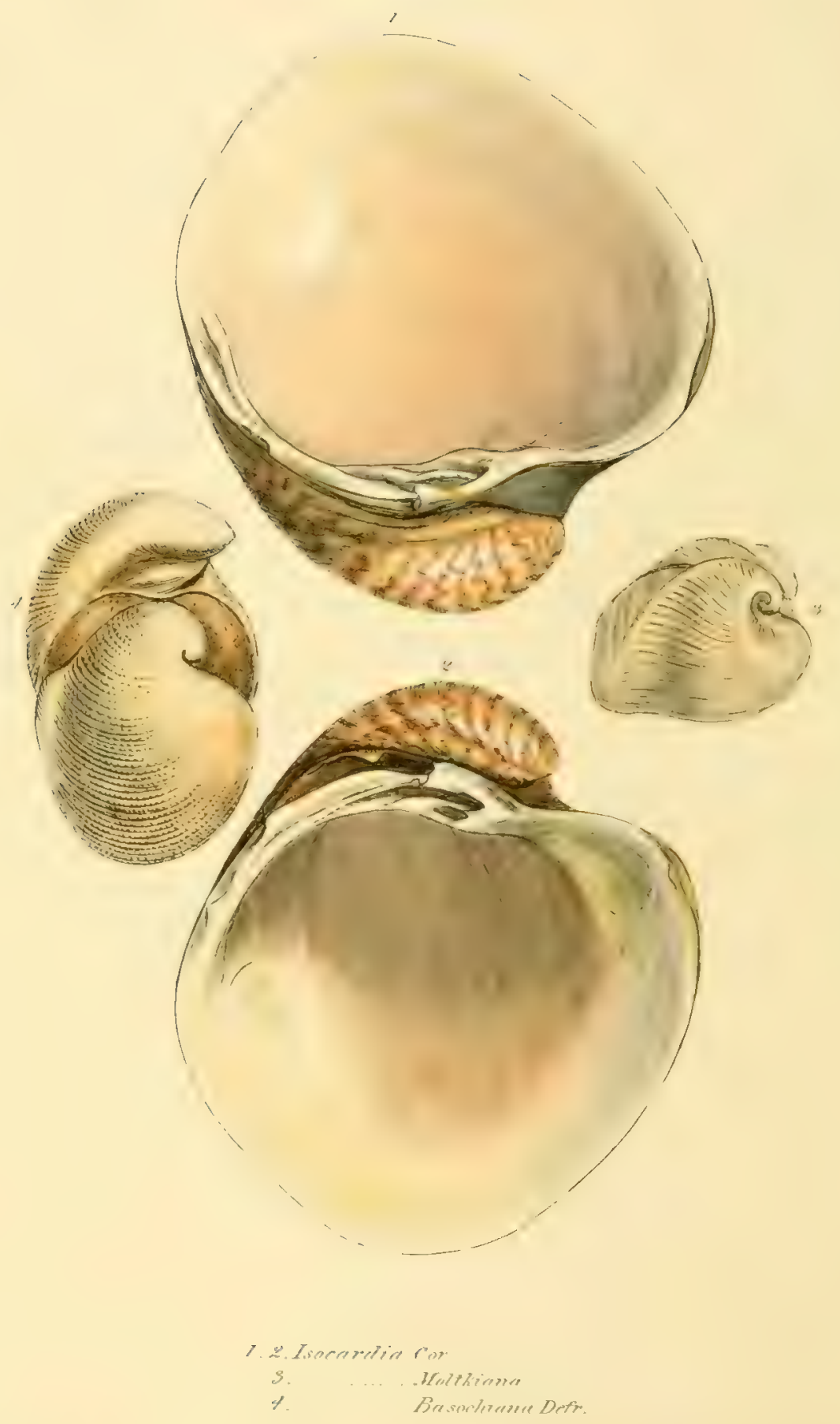


nently characteristic. It is evidently allied to that of the former genus. though placed by Linnexs amongst his Cheme, and forms an accurate transition from the Cardia to the Cardita.

The shell of Isocardia may be described as being equivalve, cordate and ventricose, with the umbones distant, divaricate, and turned inwards. There are two compressed cardinal teeth, one of which is recurved under the umbo, and there is also a single lateral tooth on the anterior side. The muscular impression of the mantle is simple, and the ligament is external.

Examples.

Pl. LXXVIII. Fig. 1.

Isocardis cor, Lamarck, Anim. sans vert,, new edit,, vol. vi.p. 445. Enc. Méth., pl. 232. f. 1, $\alpha, b, c, d$.

Chama cor, Linnæus.

Cardita cor, Bruguière.

Bucardia communis, Schumacher.

\section{Pl. LXXVIII. Fig. 2.}

Isocardia Moltkiana, Lamarck, Anim. sans vert., new edit,, vol. vi. p. 447. Enc. Méth., pl. 233. f. 1, $a, b, c, d$. Chama Moltkiana, Chemnitz.

Cardita Moltkiana, Bruguière.

\section{Pl. LXXVIII. Fig. 3. (fossil.)}

Isocandia Basochina, Defrance, Dict. des Sciences Naturelles. Sowerby, Genera of Shells, No. 7.

\section{CARDITA, Bruguière.}

'Testa aequivalvis, inæquilateralis, suborbicularis vel transversa, costis ab umbonibus ad marginem divergentibus, margine crenulato. Cardo dentibus in valvâ alterâ duobus obliquis, altero elongato, crasso, 
altero subrecto, breviusculo ; in alterit dente unico elongato, crasso, obliquo. Impressio muscularis pallii integra. Ligamentum externum.

The genus Cardita, as originally proposed by Bruguière, included four other well-knorvu genera, instituted by Lamarck, Isocurdia, Cypricardin, Hiutella, and I'enericardiu. The first and second of these we readily acknowledge; the third, as we have already shown (vide p. 70), is but the young of Saricare rugosa ; and the fourth we re-unite to the Cardita, in accordance with the opinion of Sowerby and Deshayes. This lastmentioned genus, Ienericurdia, was evidently selected by Lamarck, because he consiclered its shell to be intemediate between that of the Conchucen and the Cardiucen, and it was arranged by him in the first of these families, under the impression that it partook more of the characters of that division.

The shell of Cardita may be described as being equivalve, inequilateral, suborbicular or transverse, with ribs or furrows diverging from the umbones to the margin, leaving it crenulated. The hinge consists of two oblique teeth in one valve, one of which is elongated and thick, the other nearly straight and rather slort; in the other valve there is but one thick oblique elongated tooth. The muscular impression of the mantle is entire; and the ligament is external.

\section{Examples.}

PI. LXXIX. Fig. 1 and 2.

Cardita calyculatus, Lamarck, Anim. sans vert., new edit, vol. vi. p. 431. Enc. Méth., pl. 233. f. 6.

Chama calyculata, Linnæus.

Mytilicardia calyculata, De Blainville:(subgenus.)

Pl. LXXIX. Fig. 3.

Cardita sulcatus, Bruguière, Enc. Méth. vers, vol. i. p. 405. Lamarck, Anim. sans vert., new edit., vol. vi.p. 426. 
Diate LXXIX.
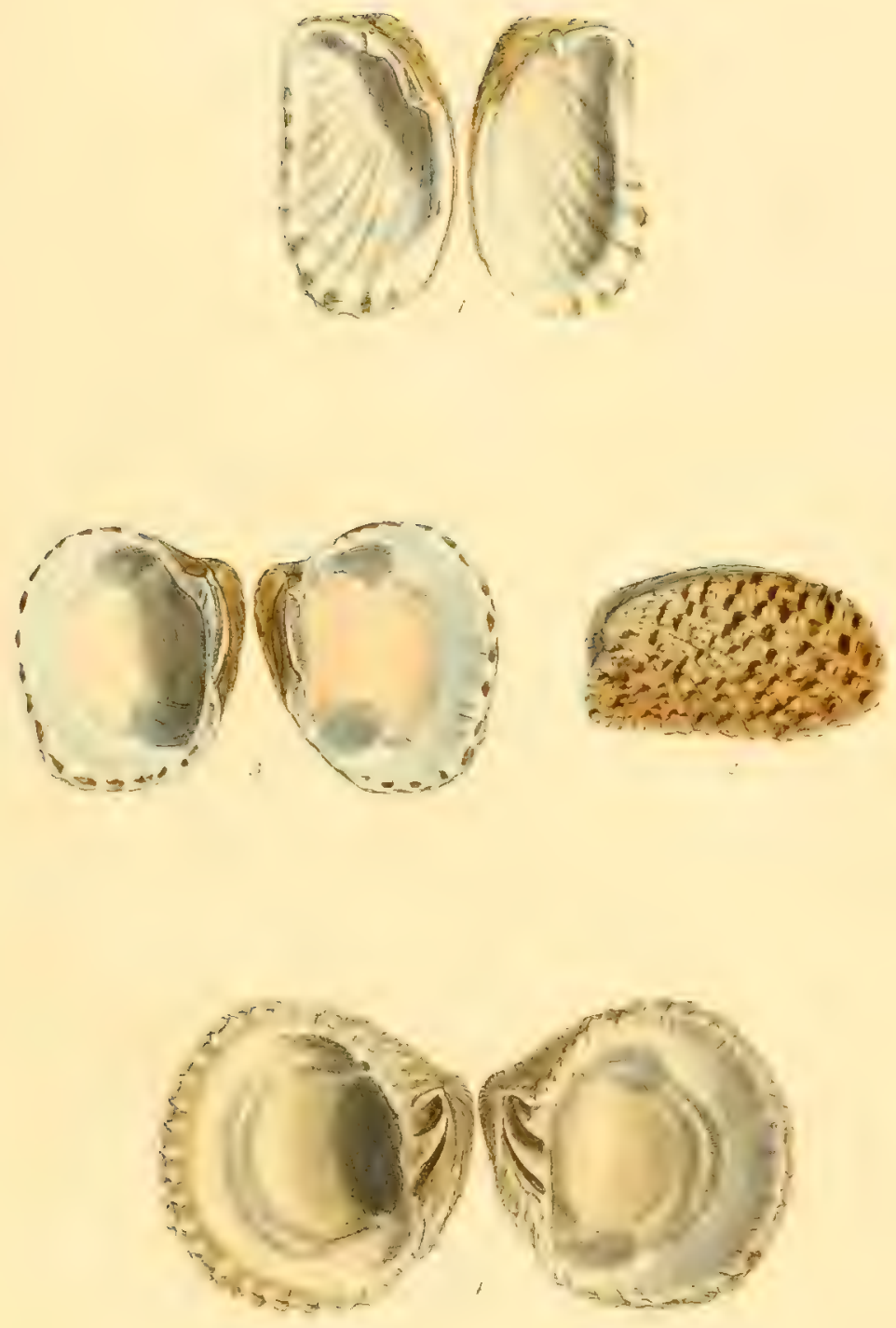

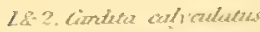

$$
\begin{aligned}
& \text {.........s. }
\end{aligned}
$$



Chama antiquata, Linnæus.

Venericardia sulcata, Payrandeau.

Pl. LXXIX. Fig. 4. (fossil.)

Cardita imbricatus, Sowerby, Genera of Shells, No. 20. Deshayes, Enc. Méth. vers, vol. ii. p. 199.

Venus imbricata, Gmelin.

Venericardia imbricata, Lamarck.

CYPRICARDIA, Lamarck.

Testa xquivalvis, inæequilateralis, obliquè vel transversim elonģata, latere postico brevissimo. Dentes cardinales tres infra umbonem utriusque valvæ impositi; cum dente unico laterali subelongato, anticè porrecto. Impressio muscularis pallii indistincta. Ligamentum externum.

The shell of Cypricardia may be distinguished from that of Cardite by its more oblong or elongated form, and lateral tooth ; De Blainville, however, is unwilling to distinguish the former but as a subgenus. Both genera are intimately allied to the Chumacea, and might with equal propriety be referred to that family : a transition may, nevertheles.s, be traced from the Veneres to the Carditc with great accuracy.

We may describe the shell of Cypricardia as being equivalve, inequilateral, and obliquely or transversely elongated, with the posterior side very short. There are three cardinal teeth placed beneath the umbo in each valve, with a single, rather elongated, lateral tooth extending along the anterior side. The palleal impression is indistinct, and the ligament is external. 


\section{Example.}

Pl. LXXX. Fig. 1 and 2.

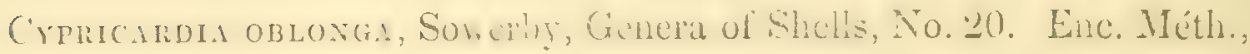
pl. 234. f. 2.

Chama oblonga, Linnæeus.

Chama Guinaica, Chemnitz.

Cardita carinata, Bruguière.

Cypricardia Guinaica, Lamarck.

Cardita Guinaica, De Blainville (subgenus Cypricardia).

\section{Family 10. ARCACEA.}

Te-ta plerumpue anduralvis; carcine dentibus parvis numerosis instructo, in seriem vel rectam vel arcuatam dispositis.

'The generic tyee of this tambly may be said to exhibit a most distinct and well-defined andemblage of characters; the teeth of the shell are small and numerous, set in a straight or curved line, and the ligament is external. Yet we are compelled to admit with the Arcacea, because of the similarity of its animal, a genus in which a direct change talies place in the ponition of the licmment, it being internal, as in the shell of the Mactracea. Now, when we meet with such an anomalous union of characters as are cxhibited in the shell of Nucula, the difficulty becomes cmbarrasing, because the arrangement of the ligament forms no inconsirlerable feature in determining fanilies; we must, however, be guided by those aftinities which are estemen of most importance in the organization of the animal. For this reason we are led to follow Lamarck and Gray, by retaining in this family a genus which some eminent conchologists have entirely removed.

The shell of the Areacen is senerally equiralve, and the hinge consists of a row of numerous smal! teeth set either in a straight or curved line 
Plate IIIX.

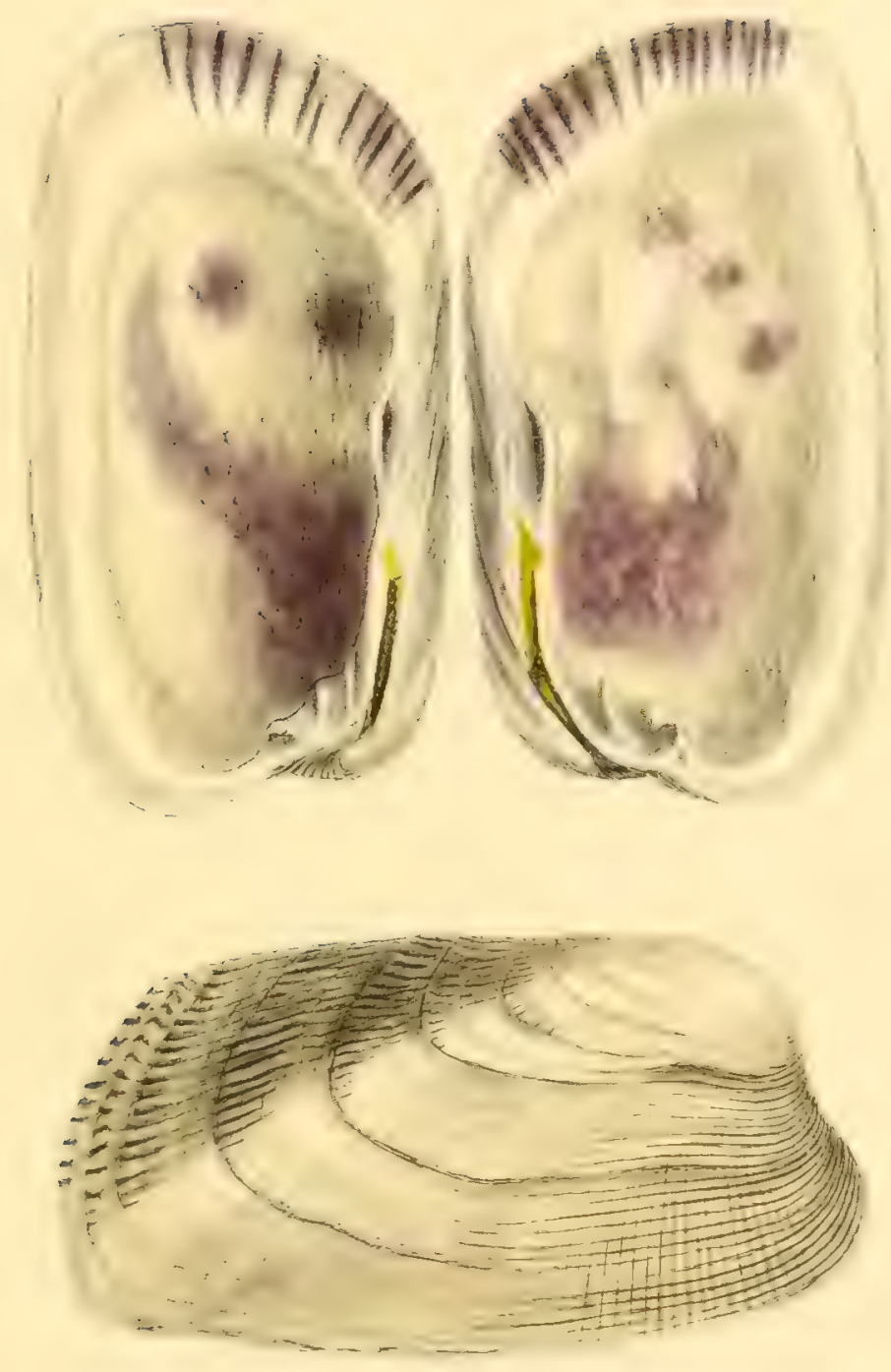

cipricartia oblomed 

in each valve; the teeth of one valve closely interlocking with those of the other. The Arcacea are divided into four genera, as follows:

Cucullea.

Arca.

Pectunculus.

Nucula.

\section{CUCULLAA, Lamarck.}

Testa subinæquilateralis, trapeziformis, ventricosa, umbonibus distantibus, incremento areæ ligamenti gradatim discedentibus. Cardo linearis, rectus, dentibus minimis subtransversis, ad extremitates costaformè diffusis. Impressio musculi antici super marginem angulatum, in auriculam productum, imbuta. Ligamentum externum, ad partem areæ inter umbones affixum.

Lamarck instituted the genus Cuculliea on account of there being a broad concamerated shelf in the interior of the shell, for the attachment of the anterior muscle. Some authors have refused to acknowledge the distinction, because this character is common, in an inferior degree, to some species of Arca and Pectunculus; it is, however, especially marked in this genus; and the area or facet between the umbones, which is formed by the gradual thickening of the dorsal edges, is also very characteristic in its appearance.

The shell of Cucullæa may be described as rather inequilateral, trapeziform, and ventricose, with the umbones distant, gradually dividing or receding as the area of the ligament increases. The hinge is linear, straight, composed of a row of small subtransverse teeth, taking at each extremity the form of ribs. The anterior muscular impression is visible upon a sharp edge, produced in the shape of an ear or concamerated VOL. I. 
shelf. The ligament is external, attached to a part of the area between the umbones.

\section{Examples.}

Pl. LXXXI. Fig. 1, 2 and 3.

Cucullea auriculifera, Lamarck, Anim. sans vert., new edit, vol. vi. p. 455. Enc. Méth., pl.304.f. 1. $a, b, c$.

Arca cucullus, Gmelin.

Arca cucullata, Chemnitz.

Arca concamerata, Martini.

Arca concamera, Bruguière.

Arca auriculifera, De Blainville.

Pl. LXXXI. Fig. 4. (fossil.)

Cucullak decussata, Park., Org. Remains, vol. iii. p. 171. Sowerby, Min. Conch., pl. 206. f. 3 and 4. Deshayes, new edit. of Lamarck, vol. vi. p. 456.

$A R C A$, Linnæus.

Testa a'puivalvis aut subequivalvis, insequilateralis, trapeziformis, plus minusve ventricosa, epidermide pilosì plerumque induta; umbonibus distantibus, incremento areæ ligamenti gradatim discedentibus. Cardo linearis, rectus, dentibus minimis, plurimis. Ligamentum externum ad aream inter umbones affixum. Animal interdum bysso instructum.

The genus Arca is very numerous in species, and may be easily recognised by the distinct and never-failing character which its shell exhibits in the number and rectilinear position of the teeth. Some of the Arcx are characterized by having a byssus; but, although a slight aperture or the indication of one is generaliy left for the passage of it between the edges of the ralves, this feature is difficult to be ascertained, and cannot 
Plate LXXXI.

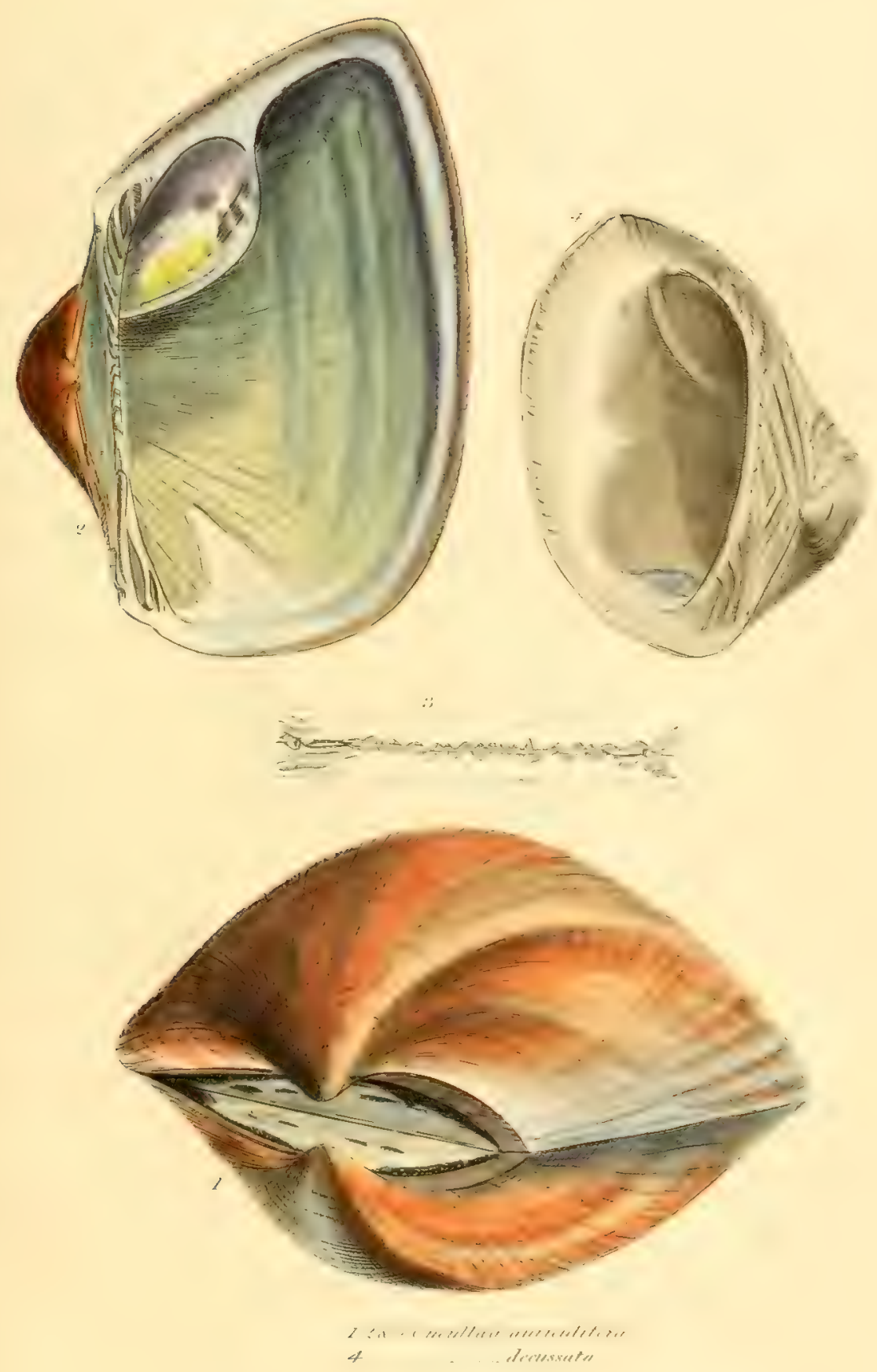





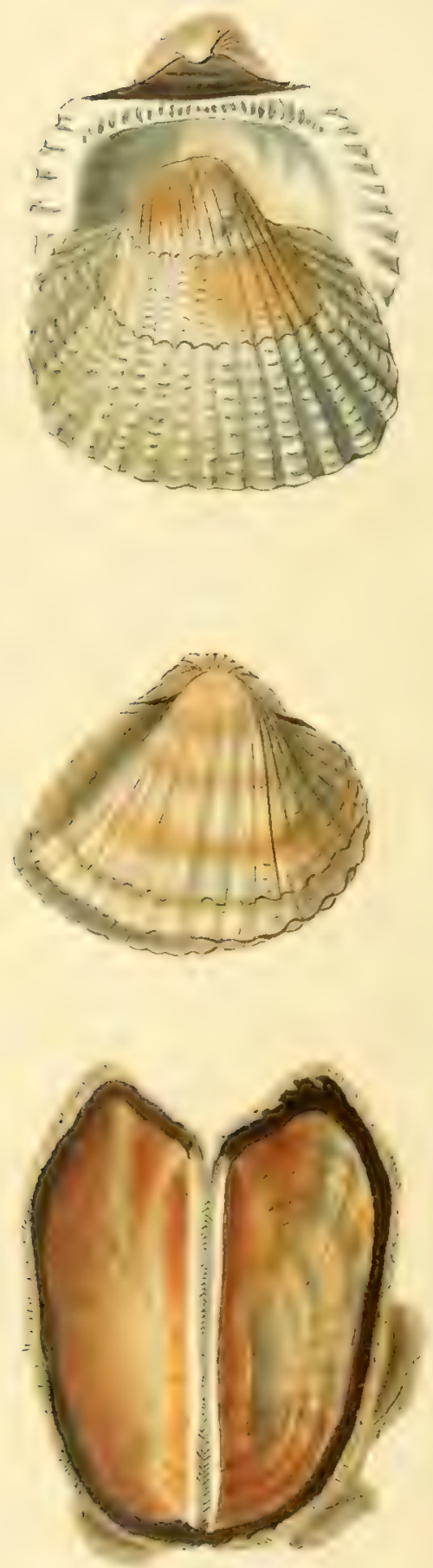
be relied upon as a generic character. The presence of a byssus is peculiar to some of the Myce and one or two other genera; we therefore cannot appreciate the genus Byssoarca of Swainson.

The shell of Arca may be described as being equivalve or nearly so, inequilateral, and more or less ventricose ; it is often covered with a hairy or fibrous epidermis; and the umbones are distant, receding from each other by the increase of the area between them. The hinge is linear, straight, consisting of a series of numerous small teeth. The ligament is external, attached to the area between the umbones. The Arca are sometimes provided with a byssus.

\section{Examples.}

\section{PI. LXXXII. Fig. 1.}

Arca Now, Linnæus, Syst. Nat., p. 1140. Lamarck, Anim. sans vert., new edit, vol. vi. p. 461. Enc. Méth., pl. 303. f. 1. $a, b, c$.

Byssoarca Noæ, Swainson.

Pl. LXXXII. Fig. 2.

Arca granosa, Linnæus, Syst. Nat., p. 1142. Lamarck, Anim. sans vert., new edit., vol. vi. p. 47l. Enc. Méth., pl.307. f. 1. $a, b$.

Pl. LXXXII. Fig. 3.

Arca inequivalvis, Bruguière, Dict., No. 16. Lamarck, Anim. sans vert., new edit., vol. vi. p. 472. Enc. Méth., pl. 305. f. 3. 6 . Arca Indica, var., Dillwyn.

\section{PECTUNCULUS, Lamarck.}

Testa orbicularis, sublenticularis, æequivalvis, subæequilateralis, epidermide pilosâ sæepè induta ; umbonibus parùm separatis, areâ intermediâ parvâ; marginibus valvarum plerumque crenulatis. Cardo arcuatus, P 2 
dentibus numerosis obliquis; medianis sæpissimè obsoletis. Ligamentum externum. Animal nunquam bysso affixum.

The leading characters of Arca are exhibited in this genus in a modified form; the shell being orbicular has the teeth set in a curved line, and the umbones are much closer, with but a small area between them.

The shell of Pectunculus is described as sublenticular, equivalve, nearly equilateral, often covered with a hairy or downy epidermis, and the umbones are but little separated; the valves are always close shut, and generally crenulated round the inner margin. The hinge, which is curved, consists of a series of numerous small teeth, the middle of which are very often obsolete. The ligament is external, and the animal never has a byssus.

\section{Examples.}

PI. LXXXIII. Fig. 1.

Pectunculus pilosus, Lamarck, Anim. sans vert, new edit, vol. vi. p. 488. Enc. Méth., pl. 310. f. 2.

Arca pilosa, Linnaus.

Pl. LXXXIII. Fig. 2. (fossil.)

Pectunculus pulvinatus, var. Lamarck, Anim. sans vert., new edit., vol. vi. p. 496. Deshayes, Desc. des Coquilles fossiles, pl. 35. f. 15 to 17 .

\section{NUCULA, Lamarck.}

Testa transversa, aut tenuis aut solida, æquivalvis, inæequilateralis, intis interdum margaritacea, extùs epidermide aut viridi aut fusco-olivaceâ induta; umbonibus contiguis, areâ intermediâ nullâ. Cardo linearis, foveâ medianâ obliquè productî ligamentum internè gerente ; dentibus numerosis, acutis, subrecurvis, in seriem utrinque dispositis. Impressio muscularis pallii integra. 
Plate LXXIIII.

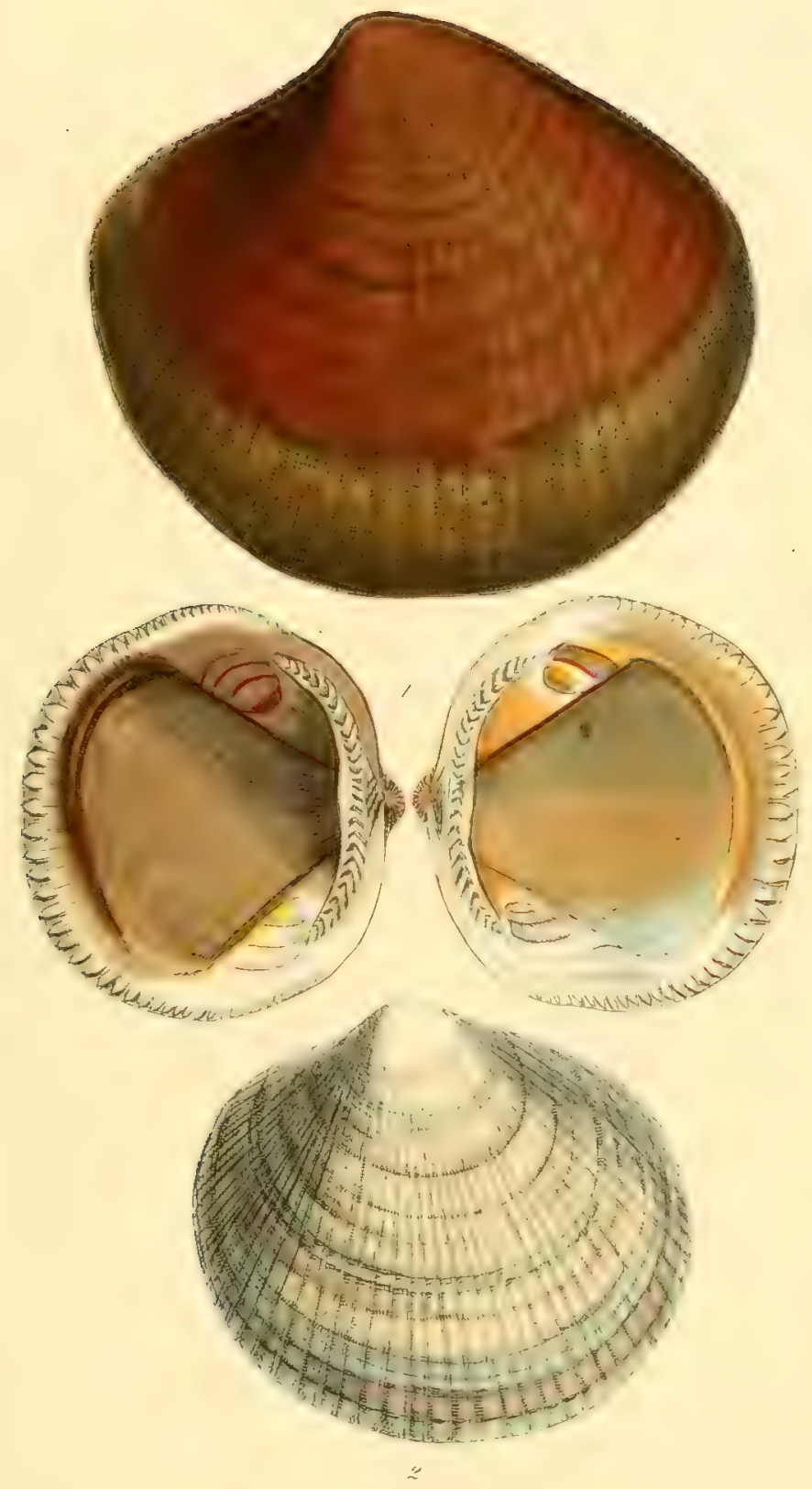

1. Pestunecules pitosis.

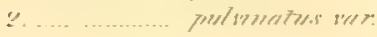



The genus Nucula presents a most anomalous union of characters, and no little embarrassment arises in deciding its natural situation in the system. In following the arrangement of Lamarck, we are guided by the anatomical observations of M. Quoy, who clearly shows that the animal of Nucula has a decided affinity with that of the Arcacea; but in addition to this important testimony, it will be found that Gray still includes this genus with his family of the Arcada. We find, nevertheless, upon examining the shell, that a strong opposing character exists in the position of the ligament, it being internal, inserted in a small central cardinal pit within each valve. For this reason the genus in question has been naturally referred by several eminent conchologists, Turton, Leach, Sowerby, \&c. to the family of the Mactracea. But since these authors wrote upon the subject, the discovery of a more extended series of Nuculæ has enabled us to lay out two separate and distinct divisions of species: in one we observe that the shell is thin, and covered with a green horny epidermis; in the other it is thick and solid, with a dark brown epidermis; the interior of the latter differs also from that of the former in being pearly. Now the principal generic characters of each are the same; yet if the position of the ligament were not regarded, the former division of species might with just as much propriety be placed near Solenella in the family of the Solenacea. By the internal ligament the Nucula belong to the Mactracea: this, however, is the only character which they exhibit in common with that family; we must be therefore guided by the affinitics of the animal, which, as before stated, have been satisfactorily decided as approaching to the Arcacea.

The shell of Nucuia may be c'escribed as being transverse, either thin or solid, equivalve, inequilateral, often pearly within, and covered externally with either a green, or dark olive-brown, epidermis; the umbones are contiguous, there being no intermediate area as in the rest of the Arcacea in consequence of the change in the position of the ligament. The hinge is linear, with an internal obliquely-produced pit in the centre for the reception of the ligament ; the teeth are numerous, sharp, rather recurved, set in a straight series on each side of the ligamentary pit. The muscular impression of the mantle is entire. 
Examples.

Pl. LXXXIV. Fig. 1.

Nucula ranceolata, Lamarck, Anim. sans vert., new edit, vol. vi. p. 504. Sowerby, Genera of Shells, No. 17.

\section{PI. LXXXIV. Fig. 2.}

Nucula elongata, Sowerby, Proceedings Zool. Soc., 1832, Part 2. p. 197.

\section{Pl. LXXXIV. Fig. 3.}

Nucula crenifera, Sowerby, Proccedings Zool. Soc., 1832, Part 2. p. 197.

\section{Pl. LXXXV. Fig. 4.}

Nucula Nicobarica, Lamarck, Anim. sans vert., new edit., vol, vi. p. 505. Enc. Méth., pl. 309. f. 8.

Arca Nicobarica, Bruguière.

Arca pellucida, Gmelin.

Arca lavigata, Dillwyn.

Pl. LXXXV. Fig. 5.

Nucula curvirostra, Humphrey, MSS. Sowerby, Cat. of Nucula,

No. 7. Sowerby, Jun., Conch. Illus., f. 5.

Arca rostrata, Montague.

PI. LXXXV. Fig. 6.

Nucul. Pella, Lamarck, Anim. sans vert., new edit., p. 505. Sowerby,

Genera of Shells, No. 17. f. 4.

Arca pella, Linnæus.

Pl. LXXXV. Fig. 7.

Nucula Parva, Sowerby, Cat. of Nuculæ, No. 12. Sowerby, Jun., Conch. Illus., f. 7.

Pl. LXXXV. Fig. 8.

Nucula costellata, Sowerby, Proceedings Zool. Soc., 1832, p. 198; and Cat. of Nuculæ, No. 13. Sowerby, Jun., Conch. Illus., f. 8. 


Plate LXIXT.
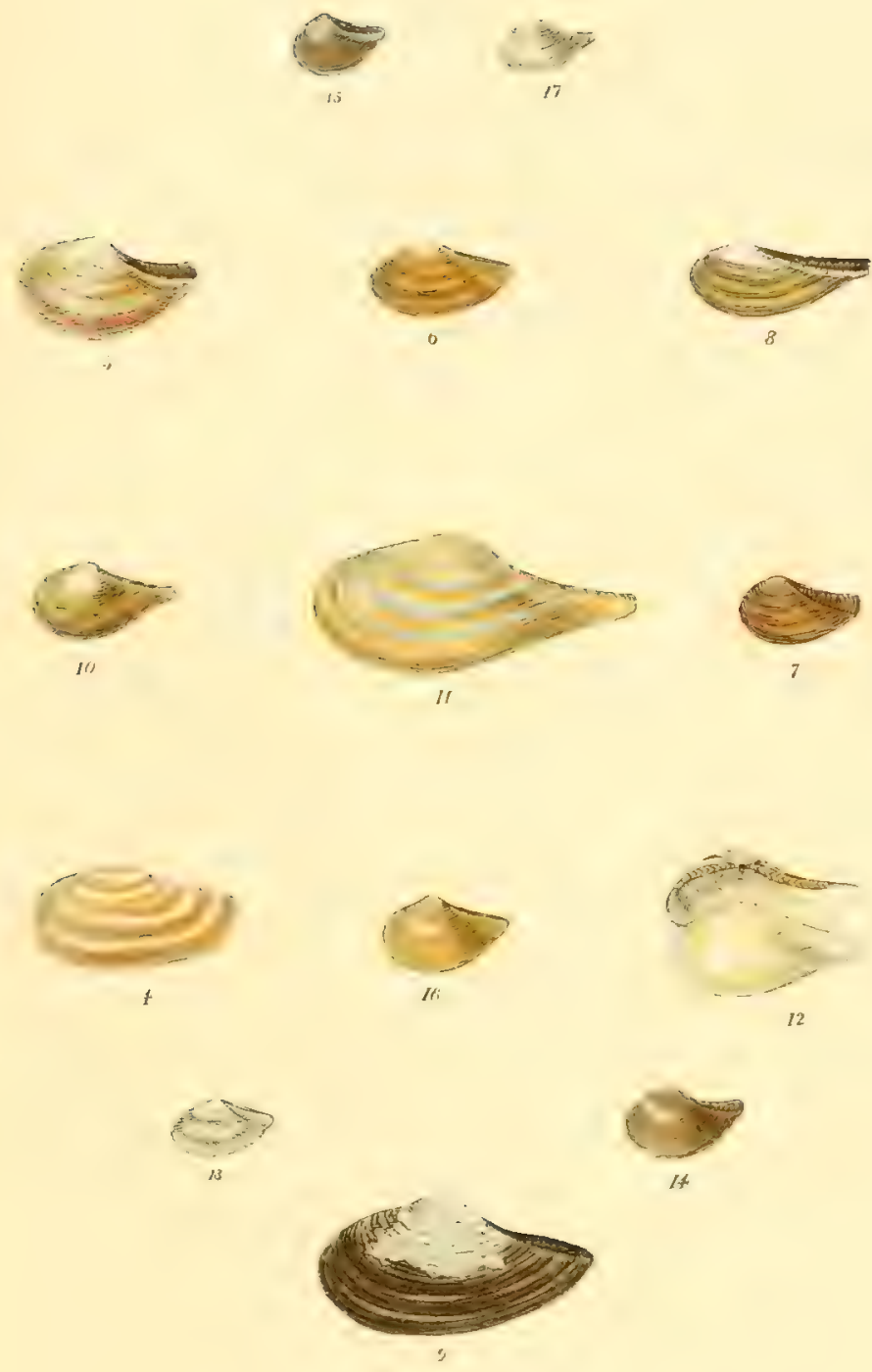

Pl. LXXXV. Fig. 9.

Nuclla gibbosa, Sowerby, Proceedings Zool. Soc., 1832, p. 198; and

Cat. of Nuculæ, No. 14. Sowerby, Jun., Conch. Illus., f. 9.

Pl. LXXXV. Fig. 10.

Nucula eburnea, Sowerby, Proceedings Zool. Soc., 1832, p. 198; and

Cat. of Nuculæ, No. 15. Sowerby, Jun., Conch. Illus., f. 10.

PI. LXXXV. Fig. 11.

Nucula polita, Sowerby, Proccedings Zool. Soc., 1832, p. 198; and

Cat. of Nuculæ, No. 16. Sowerby, Jun., Conch. Illus., f. 11.

Pl. LXXXV. Fig. 12.

Nucula nasuta, Sowerby, Cat. of Nucula, No. 17. Sowerby, Jun., Conch. Illus., f. 12.

Pl. LXXXV. Fig. 13.

Nuctla fabula, Sowerby, Cat. of Nuculæ, No. 18. Sowerby, Jun., Conch. Illus, f. 13.

PI. LXXXV. Fig. 14.

Nucula Elenensis, Somerby, Proceedings Zool. Soc., 1832, p. 198; and

Cat. of Nuculæ, No. 19. Sowerby, Jun., Conch. Illus., f. 14.

Pl. LXXXV. Fig. 15.

Nucula cuneata, Sowerby, Proceedings Zool. Soc., 1832, p. 198 ; and

Cat. of Nuculæ, No. 20. Sowerby, Jun., Conch. Illus., f. 15.

Pl. LXXXV. Fig. 16.

Nucula striata, Sowerby, Cat. of Nuculæ, No. 21. Sowerby, Jun., Conch. Illus, f. 16.

\section{Pl. LXXXV. Fig. 17.}

Nuclla Mauritiana, Sowerby, Cat. of Nucule, No. 22. Sowerby. Jun., Conch. Illus., f. 17. 


\section{Family 11. TRIGONACEA.}

Testa xquivalvis; cardine dentibus paucis lamelliformibus, valdè intersertis.

Lamarck's family of "Les Trigonies" includes two genera, Trigonia and Castalia; the former is sufficiently distinct to claim its arrangement as a separate family, but the latter evidently belongs to that of the Nuiades; they differ also in their natural places of habitation, one being marine, the other fluviatile. At the time that these two genera were united in one family by Lamarck, the shell of each was exceedingly rare, and their animals unknown. Abundant opportunities have, however, been since afforded for examining them; and the result shows that the Trigonice are not only eminently distinct from the Castalia, but that the latter, belonging to the family of the Naiades, are, in fact, true species of the genus Unio; Castalia of Lamarck therefore must be abandoned.

The Trigonacea may be described as having an equivalve shell, with the hinge composed of a few broad lamelliform teeth, closely interlocking with each other; the following genus is the only one that can be referred to this family:

$$
\text { Trigonia. }
$$

\section{TRIGONIA, Bruguière.}

Testa æquivalvis, inæquilateralis, trigona, intus iridescenti-margaritacea, extùs costis aut sulcis, vel transversim vel longitudinaliter dispositis, obtecta. Cardo dentibus oblongis, lamelliformibus, divaricatis; in valvâ alterâ duobus, utroque latere transversim sulcatis; in alterâ 

Plate LXXXVI.
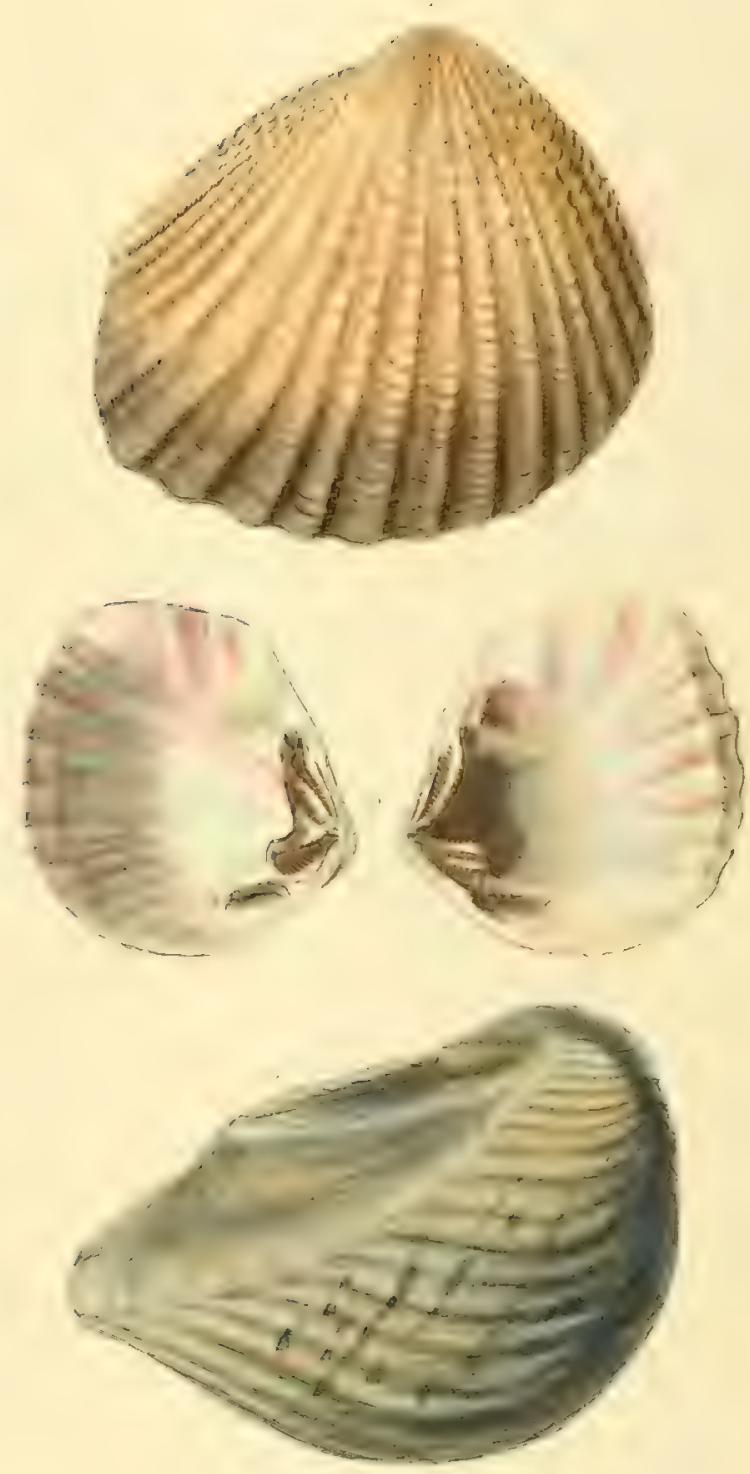

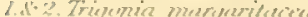


quatuor, uno latere tantum sulcato. Ligamentum externum, crassum, marginale.

It was not till some time after the introduction of this genus by Bruguière, known to him only in a fossil state, that a recent species was discovered; and we are again indebted to M. Quoy, on his return from a royage of discovery in the ship 'Astrolabe,' for the first notice of the animal. His observations on the anatomy of the Trigonia tend to establish a direct affinity between this family and the Arcacea, and singularly contirm the conjectural opinion of Lamarck, who, in speaking of the Nucule, says, "et formant une transition évidente aux Trigonies, elles lient ces dernières ì la famille des Arcacées."

The shell of Trigonia may be described as being equivalve, inequilateral, and somewhat triangular, having the interior lined with the most lustrous iridescent pearl, and the exterior covered with ribs or furrows, running longitudinally in the only recent species linown, but transversely in some of the fossil species. The hinge consists of two oblong, divaricate, lamelliform teeth in one valve, transversely sulcated on both sides; and four in the other, sulcated on one side only. The ligament is external, thick, and marginal.

\section{Examples.}

PI. LXXXVI. Fig. 1 and 2.

Trigonia margaritacea, Lamarck, Annales du Mus., vol. iv. p. 355. pl. 67. f. 2. Quoy and Gaimard, Voy. de l'Astrolabe, Mollusques, pl. 78. f. 1 to 4 .

Trigonia pectinata, Lamarck (Anim. sans vert.).

PI. LXXXVI. Fig. 3. (fossil.)

Trigonia costata, Lamarck, Anim. sans vert., new edit, vol. vi. p. 517. Enc. Méth., pl. 238.f。1. $a, b$, and f. 2. $a, b, c$. 


\section{Family 12. NAIADES}

'Testa inaquilateralis, valvis supernè aut comnatis aut liberis ; epidermide olivaceâ induta, umbonibus plus minusve erosa. Cardo irregrularis, dentibus plerumque crassissimis duobus aut pluribus; interdum cdentulus, interdum tuberculis ferc obsoletis solummodo instructus. Animal fluviatile.

The family of the Naiades includes a numerous and chanacteristic sroup of Huviatile 'Tropiopoda, chielly inlabiting the great rivers of America. They have been variously classified; but almost every attempt to effect a natural division of sena has failed to a certin extent on account of the continual diceorery of new rarieties, showing the gradual modification that extends from cne genus to another. Thus we find ourselves as much puzzled in detemining the generic distribution of the Naiades, as we were in deciding that of the marine Conchacea.

De Ferussac has devoted particular attention to the arrangement of this extensire family; lut upon consideriner the labours of the American conchologists, who, from the local advantages they possess of observing the Naiades in their natire condition, are peculiarly entitled to notice, we camot but appreciate the pains, and rery careful exposition made of them by Lea. After dividing the family into two genera, Margarita and Platiris, according to the characters of the animal, he adopts as subgenera of the first division. Unio and Anodon of Bruguière, Maryaritana of De Ferussac, Dipsess of Lench, and Pleiodon of Conrad; and the second division, which answers to Lanarch's genus Iridina, is divided into two grenera, Iridina and spath. He then sejparates the symphynote Naiades, or those with commate shells, from the nonsymphyote, or those with free shells, the former being distinguished as connate on account of the prolonged growth of each ralve behind the umbones becoming connected, as in the Cmio ulutus (Plate LXXXIX. Fig. 8.). 'This peculiarity of growth 
was originally selected by Lea as a type for the formation of a new genus, Symphynota; upon finding, howerer, that the character was not only irregular, but more or less common to many of the Naiades, he abandoned it. Even as a general rule of division, we hare but little confidence in the connate character, as it may be found to vary in the same species at different periods of growth.

In consequence of the gradual and perfect link which holds this family in connexion, we have decided upon a still more simple distribution, relying upon the typical characters of five genera only, as best calculated to simplify the arrangement. How truly we see that there is really no arbitrary division of species in nature, but that the limits which are devised by the ingenuity of man for the arrangement of created things are wholly artificial, and become sooner or later destroyed by the constant multiplication of intermediate forms and varieties!

The animal of the Naiades appears to be nearly the same throughout, excepting in the genus Iridina, where it is said to be armed with two tubes or siphons, formed by the prolonged union of the hinder parts of the mantle. Their shell may be described as being inequilateral, having the valves connate or free, covered with a thick olivaceous epidermis, and more or less eroded at the umbones. The hinge is very irregular ; there are generally two or more very thick solid teeth, often none; sometimes the hinge-margin is furnished with an irregular series of tubercles, but these also are often obsolete. 'The valves are united by a strong ligament, and the anterior muscular impression is always compound, showing the marks of one or more accessory cartilages of attachment.

The Naiades are fluviatile, and are found abundantly upon the banks of rivers, after being washed up by the tide. They are divided into five genera, as follows:
UNio.
IRIDINA.
HYRIA.
Mycetopus.

Anodon. 


\section{UNIO, Bruguière.}

Testa transversa, plerumque crassa ct solida, wquivalvis, inrequilateralis, cpidermide olivacế induta, internè iridescenti-margaritacea. Cardo dentibus lateralibus crassis duobus, rarò pluribus, in utrâque valva; altero irregulari, quasi cardinali, brevi, simplici, interdum bipartito, substriato; altero anticè producto, clongato. Impressio muscularis postica semper composita. Ligamentum externum.

By far the greater number of the Naiades, distinguished by their thick and massive teeth, are referred to the genus Unio; they were originally separated from the Linnaxu Myc by bruguiere; few species, however, were at that time known.

The shell of the Unio ambiguus, in which the teeth assume a lamelliform appearance and are more than usually striated, was selected by Lamarck as a type for the formation of a new genus, Castalia; he moreover associated it with Trigonin in a separate and distinct family, "Les Trigonies," as establishing a link between the two proximate fimilies of the Arcacca and the Naiades. 'This arrangement is now abandoned, because a marked difierence is evident in the animals of Trigonia and Castatia; one too is marine, the other fluviatile: and by the later discovery of intermediate varieties, the latter has become inseparable from the Uniones*. It is, however, but due to Lamarck to notice, that in his time the shell of Castuliu was one of extreme rarity, and became a source of erident cmbarrassinent to him; for in seeking to establish an affinity with the proximate genera Trigonia and Lnio, he is forced to the conclusion, that "cette coquille, néannoins, ne saurait étre associée ni à l'un ni à l'autre."

* The genus Castalia is still retained by Gray, who places it, together with the genus Hyria, in his family of Iridinida; we are, however, strongly inclined to question the propriety of this arrangement. 

Hate LXIIVII.
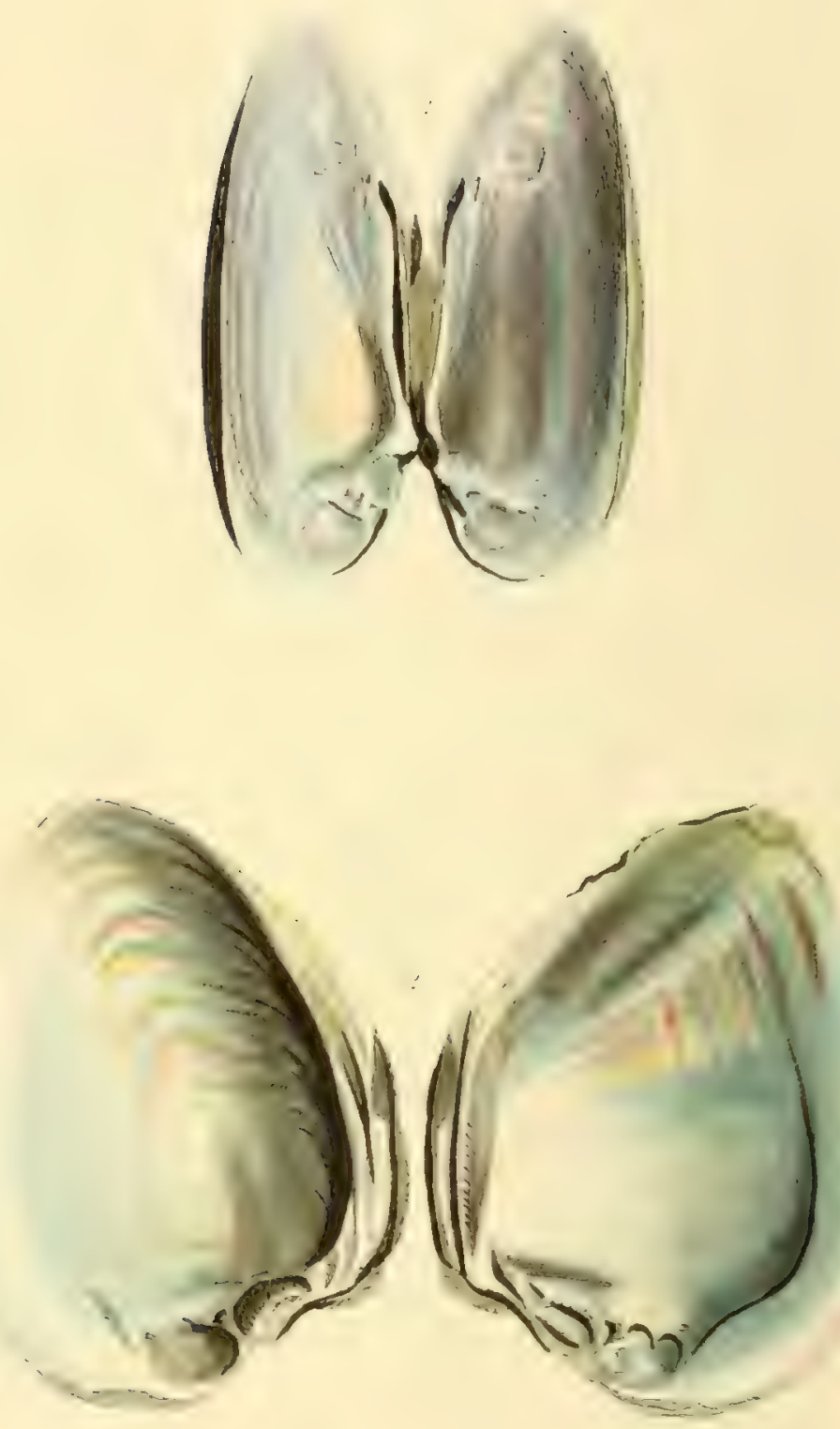

7. Ltrie onelis 

Eate LAXXTIII.
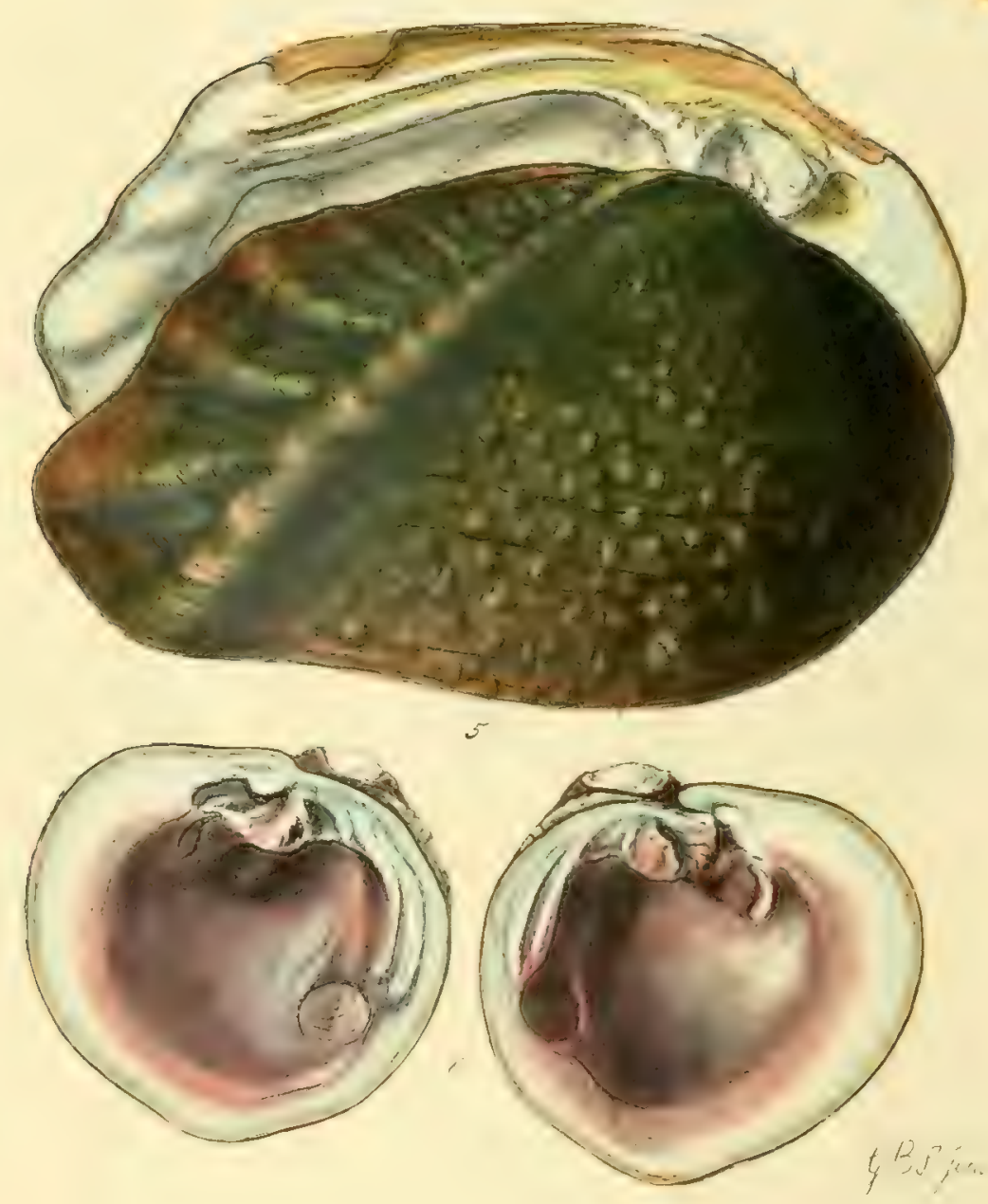
The shell of Unio may be described as being transverse, generally thick and solid, equivalve, inequilateral, and covered with an olivaceous epidermis. The interior of the valves is lined with an iridescent nacre, which is sometimes white, sometimes pink; the colour, howerer, thungh constant in some species, often varies in different individuals of the sime. The hinge is composed of two solid lateral teeth: one, which has almost the appearance of a cardinal tooth* ${ }^{*}$, is short, simple, sometimes bipartite, and somewhat striated; the other is produced anteriorly and rather long. The posterior muscular impression is always compound, and the ligament is external.

Examples.

Pl. LXXXV1I. Fig. 1.

Unio oval1s, Fleming. Wood, Gen. Conch., pl. 19. f.5. Draparnaud, Moll. terr. et fluv. de France, pl. 11. f. 1 to 4.

Mya ovalis, Montague.

Mya ovata, Maton.

Unio pictorum, var., Lamarck.

Var. Unio Michaudii, Desmoulin.

Pl. LXXXVII. Fig. 2.

Unio ambiguus, Sowerby, Genera of Shells, No. 16. De Blainville, Manuel de Malacologie, pl. 67. f. 4.

Castalia ambigua, Lamarck. Gray. D’Orbigny.

Mya ambigua, Wood.

Pl. LXXXVIII. Fig. 3.

Unio clavus, Lamarck, Anim. sans vert, new edit., vol. vi. p. 537.

Unio modioliformis, Say.

Unio scalenius, Rafinesque.

* This is actually described by Lamarck as a cardinal tooth : it cannot be denied but that it is literally cardinal, as forming part of the hinge (cardo), but it is certainly not analogous to the central tooth or teeth, technically distinguished by the term cardinal in describing the hinge of bivalve shells. 
P1. LXXXVIII. Fig. 4.

Unio Grayanus, Lea, Trans. American Phil. Soc., vol. v. pl. 9. f. 26.

Unio Grayi, Griffith's Cuvier's Animal Kingdom, pl. 21. f. 3.

Pl. LXXXVIII. Fig. 5.

Unio tuberculatus, Bames, Silliman's American Journ, vol. vi. pl. 7 f. 8 .

Unio verrucosus? Rafinesque.

\section{P!. LXXXVIII. Fig. 6.}

Unio retusus, Lamarck, Anim. sans rert., vol. vi. p. 534. Conrad, Monograph on the Unionida, pl. 8.

Unio torsus, Rafinesque.

Unio incurvus? Say.

Unio intortus?

\section{PI. LXXXIX. Fig. 7 .}

UNio NAVIFORMis, Lamarck, Anim. sans vert., new edit., vol. vi. p. 537. Deshayes, Enc. Méth. vers, vol. ii. p. 580.

Unio cylindricus, Say.

Unio solenoïdes, Rafinesque.

\section{PI. LXXXIX. Fig. 8.}

Unio alatus, Lamarck, Anim. sans vert., new edit,, vol. vi. p. 539. Say, Enc. American Conch., pl. 4. f. 2. Sowerby, Genera of Shells, No. 16. f. 5 .

Mya alata, Wood.

Unio megapterus, Rafinesque.

Symphynota alata, Lea.

Pl. LXXXIX. Fig. 9.

Unio triangularis, Barnes, Silliman's American Journ., pl. 13. f. 17. Lea, Trans. American Phil. Soc., vol. iv. pl. 16. f. 41. Lamarck, Anim. sans vert., new edit, vol. vi. p. 554 .

Unio cuneatus, Swainson. 
Plate LXXIIX.
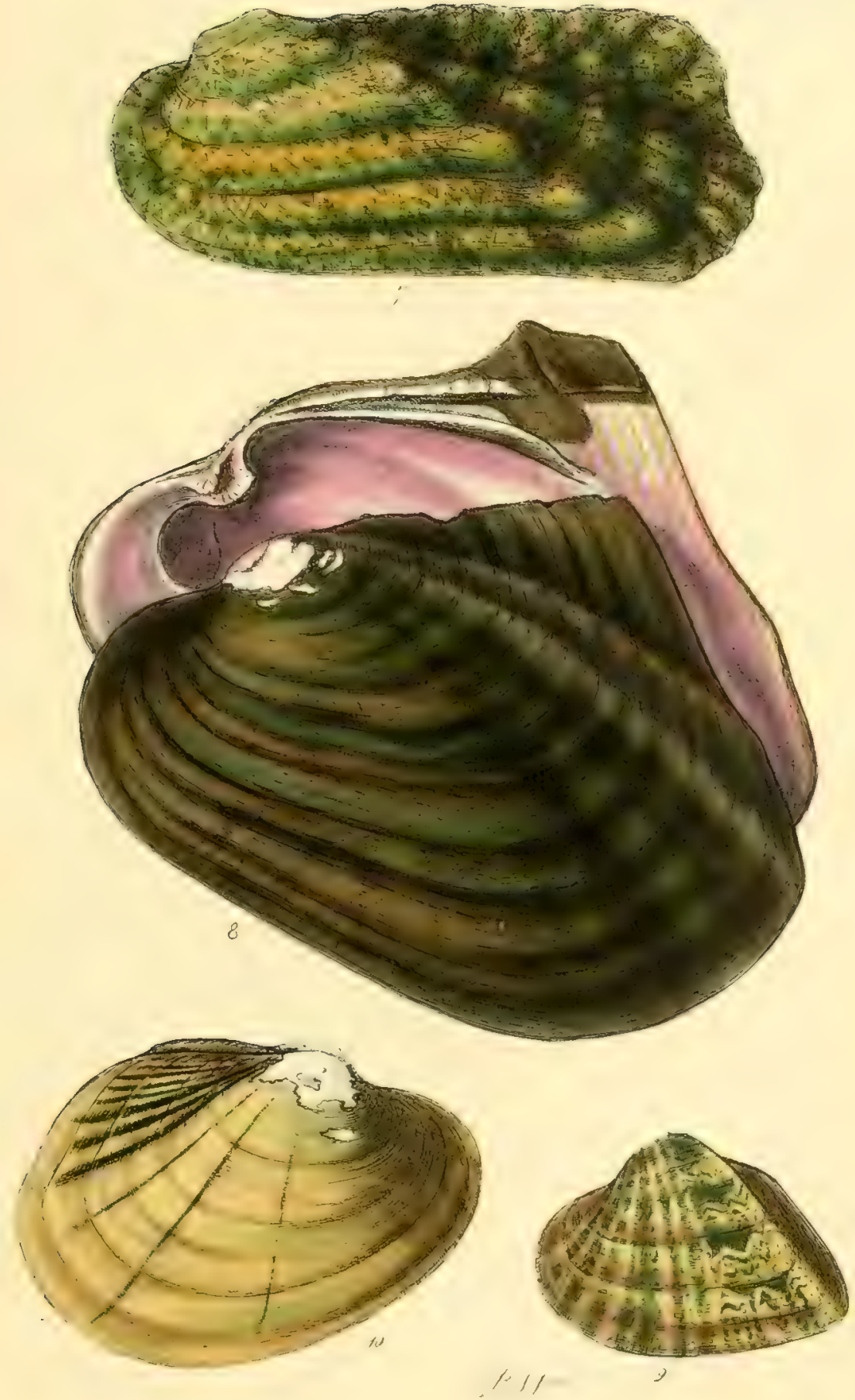

PI. LXXXIX. Fig. 10.

Unio cariosus, Say, Enc. American Conch., pl. 3. f. 2. Lamarck, Anim. sans vert., new edit., vol. vi. p. 545.

Unio luteola, Conrad.

Unio ovatus, Valenciennes.

HYRIA, Lamarck.

Testa transversa, aquivalvis, inæquilateralis, obliquè trigona, utrinque auriculata, basi truncatî, rectì, epidermide olivaceâ induta, internè margaritacea. Cardo dentibus duobus lateralibus elongatis in utrìque valvì; altero postico, quasi cardinali, multipartito; altero antico. lamellari, prælongo, in valvâ unâ bipartito. Impressio muscularis postica semper composita. Ligamentum externum, lineare.

The shell of Hyria possesses many characters in common with that of Unio, but may be nevertheless distinguished by its clongated lamellar teeth. The auriculated or winged growth of the valves producing a straight hinge-margin is also remarkable; we refrain, however, from citing this form as of generic importance, as it is nearly approached by many of the Uniones and Anodontes.

The shell of Hyria is described as being transverse, equivalve, inequilateral, obliquely triangular, and so truncated at the base as to form a straight dorsal or hinge margin. The valves are covered with an olivaceous epidermis without, and are pearly within. The hinge consists of two elongated lateral teeth, one on each side the umbo in both valves: one is posterior, somerhat approaching to the form of a cardinal tosth, and multipartite; the other is anterior, lamellar, very long, and bipartite in one valve, receiving the anterior tooth of the opposite valve. The posterior muscular impression is always compound, and the ligament is external and linear. 
Examples.

P1. XC. Fig. 1.

Hrma Symatophora, Sowerby, Genera of Shells, No. 16. Lister, Conch., pl. 160. f. 16.

Mya Syrmatophore, Linneus.

Unio Syrmatophorus, Lea.

Unio avicularis, Deshayes.

Hyria evicularis, Lamarck.

Prisodon obliquus, Schumacher.

Triptodon rugosus, Spix.

\section{Pl. XC. Fig. 2.}

Hyria corrugata, Lamarck, Anim. sans vert., new edit., vol. vi. p. 562. Enc. Méth., pl. 247. f. 2, $a, b$.

Mya angulata, Wood.

Unio corrugatus, De Blainville.

Unio angulatus, Lea.

Paxyodon ponderosus, Schumacher.

Diptodon (corrugatus?), Spix.

\section{ANODON, Bruguière.}

Testa transversa, aquivalvis, indequilateralis, plerumque tenuis, epidermide viridi incluta, interne submarearitacea. Cardo linearis, edentulus, ligamento dongato, externo. Impressio muscularis postica, semper composita.

This genus was instituted by Brugruiere for the association of certain species selected from the Linnean Myc, under the title of "Les Anodontites." The simple term Anodon, signifying without teeth, has been adopted as most expressive of the character by which they are distinwuished from the rest of the Naiades. In accordance, however, with our ohererations at the commencement of this family, it will be found, that in 
Plaic IC.
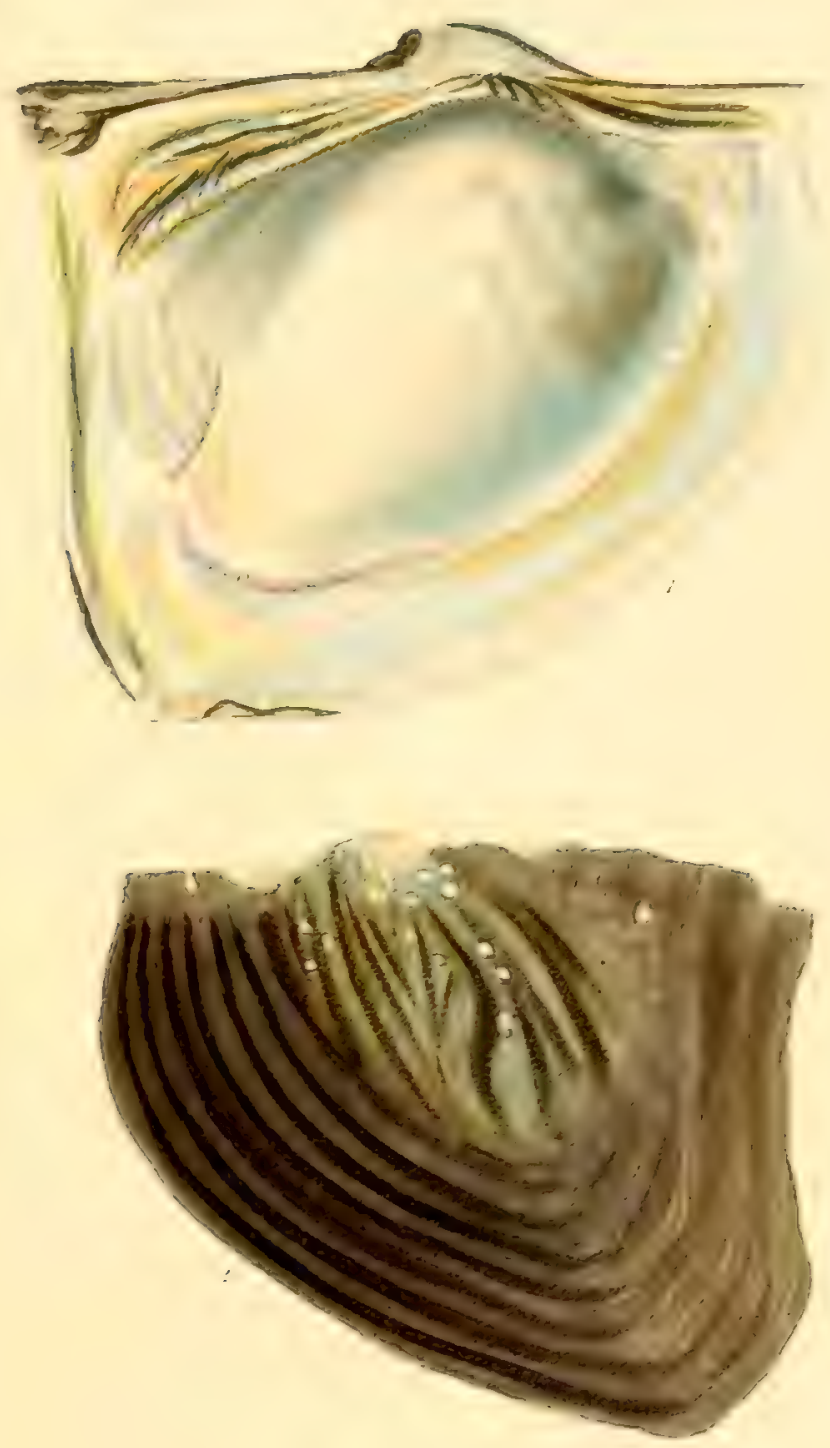


Plate XCI.

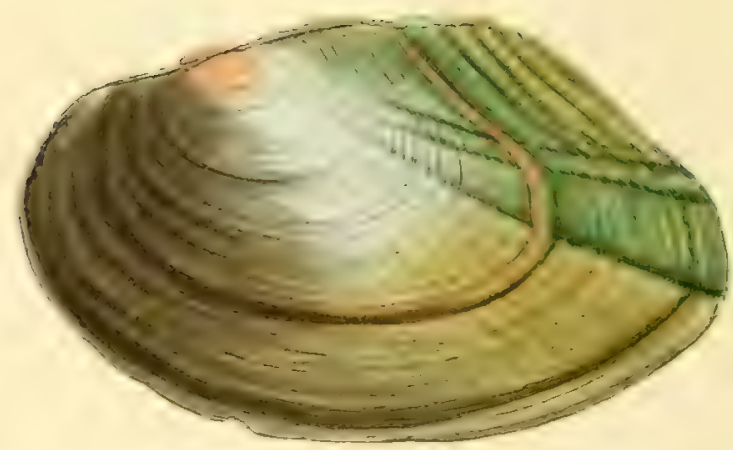


an extended series of specimens, the relative value of these distinctive characters is much reduced; we find, for instance, that in some of the shells of Anodon there is a slight indication of teeth, whilst in others of the genus Unio the hinge is nearly edentulate.

We describe the shell of Anodon as being transverse, equivalve, inequilateral, generally thin, covered with a green epidermis, and somewhat pearly within. In the young state the shell is rather depressed, but it increases in convexity as it increases in age. The hinge is linear, edentulate or destitute of teeth, with a long external ligament, and the impression of the posterior muscle is always compound.

\section{Example.}

\section{Pl. XCI. Fig. 1 and 2.}

Anodon Anatrus, Lamarck, Anim. sans vert, new edit., vol. vi. p. 565. Sowerby, Genera of Shells, No. 17. Pennant, Zool. Brit., pl. 68. f. 79 .

Mytilus anatinus, Linnæus.

Unio anatinus, Deshayes.

\section{IRIDINA, Lamarck.}

Testa transversa, subcylindrica, xquivalvis, inæquilateralis, epidermide olivaceâ induta, internè rubro-margaritacea, plus minusve iridescens. Cardo linearis, prælongus, versùs medium subattenuatus; edentulus, sed tuberculis inacqualibus subcrenatis crebris per longitudinem instructus; ligamento externo, marginali. Impressio muscularis postica semper composita.

The Iridinæ are, of all the Naiades, most entitled to a generic distinction. In the animal of the preceding genera the linder part of each lobe of the mantle is simple and free; but in this genus it is united, and so prolonged as to form two tubes or siphons. 
Like the Anodontes, they have a shell entirely destitute of teeth, but the hinge margin is furnished throughont with a number of thickly-set tubercles. In some species, as in the Iridina elonguta, Plate XCII. (Sputhu clongatu, Lea), the hinge-tubercles are almost obsolete; in others, as in the Iridinu oratu, Plate XCIII. (Pleiodon Macmurtriei, Conrad), they are very fully developed. The nearest approach of Anodon to this genus is in the Anodon dipsas (Dipsas plicata, Leach, Cristaria, Schumacher).

The shell of Iridina may be described as being transverse, nearly cylindrical, equivalve, inequilateral, covered with an olivaceous epidernis, and the interior is lined with a reddish pearl, exhibiting a more or less iridescent lustre. The hinge is linear, very long, and somewhat attenuated towards the middle; there are no teeth, but the margin is furnished with a number of subcrenated, close-set tuhercles throughout its entire length. The ligament is marginal and external, and the impression of the posterior adductor muscle is always compound.

These shells abound in the Nile and other rivers of Africa, and are found in company with those of the Galathca radiata.

Cailliaud observes, that they are used by the natives of Lower Egypt in preparing flax, and also as spoons for measuring oil, butter, and different kinds of provisions.

\section{Examples.}

Pl. XCII. Fig. 1 and 2.

Iridina elongata, Sowerby, Genera of Shells, No. 7 . Anodonta exotica, var., De Blainville.

Iridina exotica, var., Deshayes.

Spatha elongata, Lea.

Pl. XCIII. Fig. 1 and 2.

Iridina ovata, Swainson, Journ. Acad. Nat. Sciences of Philadelphia, vol. vii. Part I. pl. 13. Jay's Cat. of Shells, 3rd edit., p. 28. Pleiodon Macmurtriei, Conrad. 
Plate XCTT.
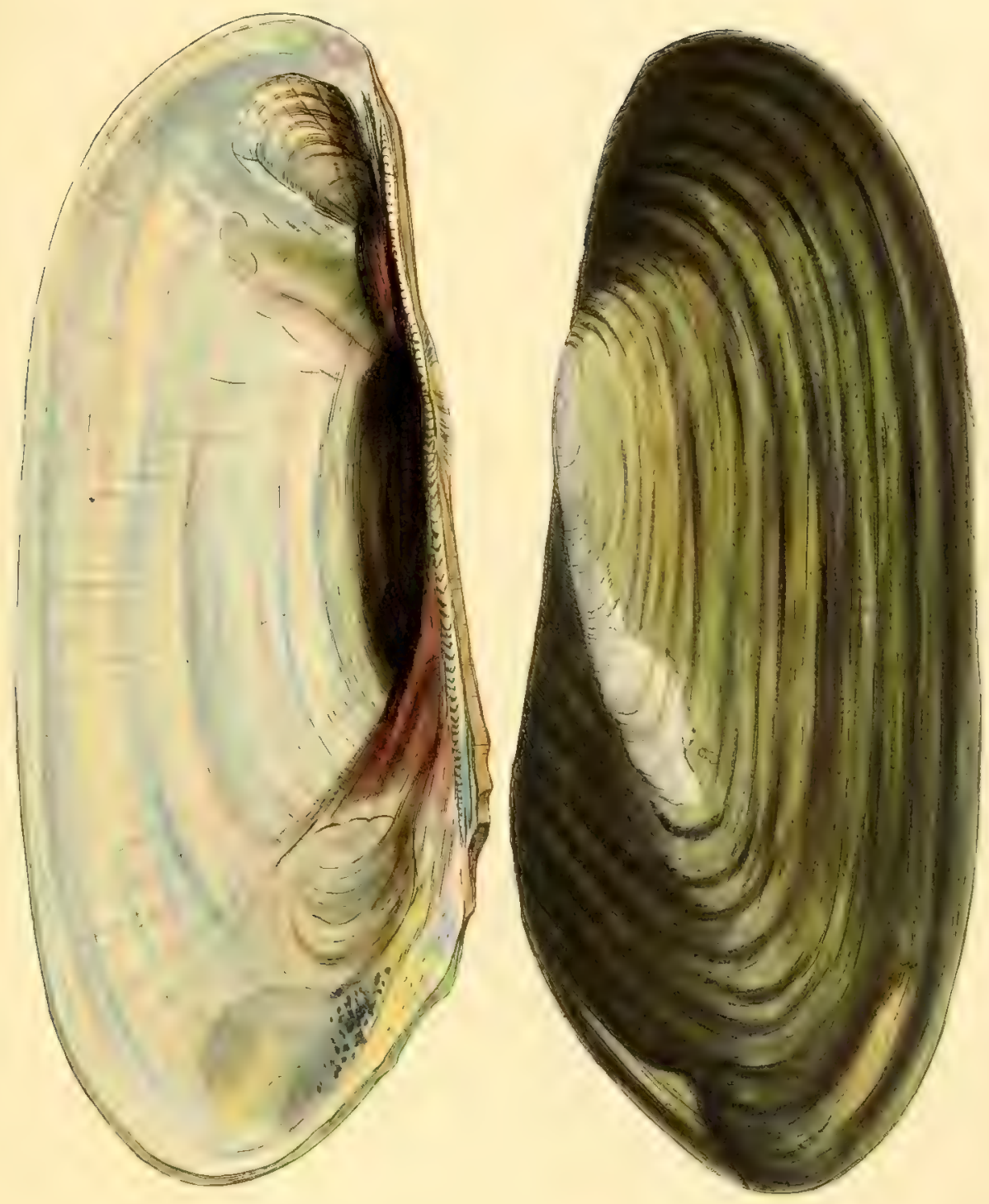

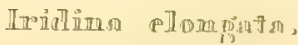

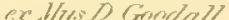



Plate XCIII.
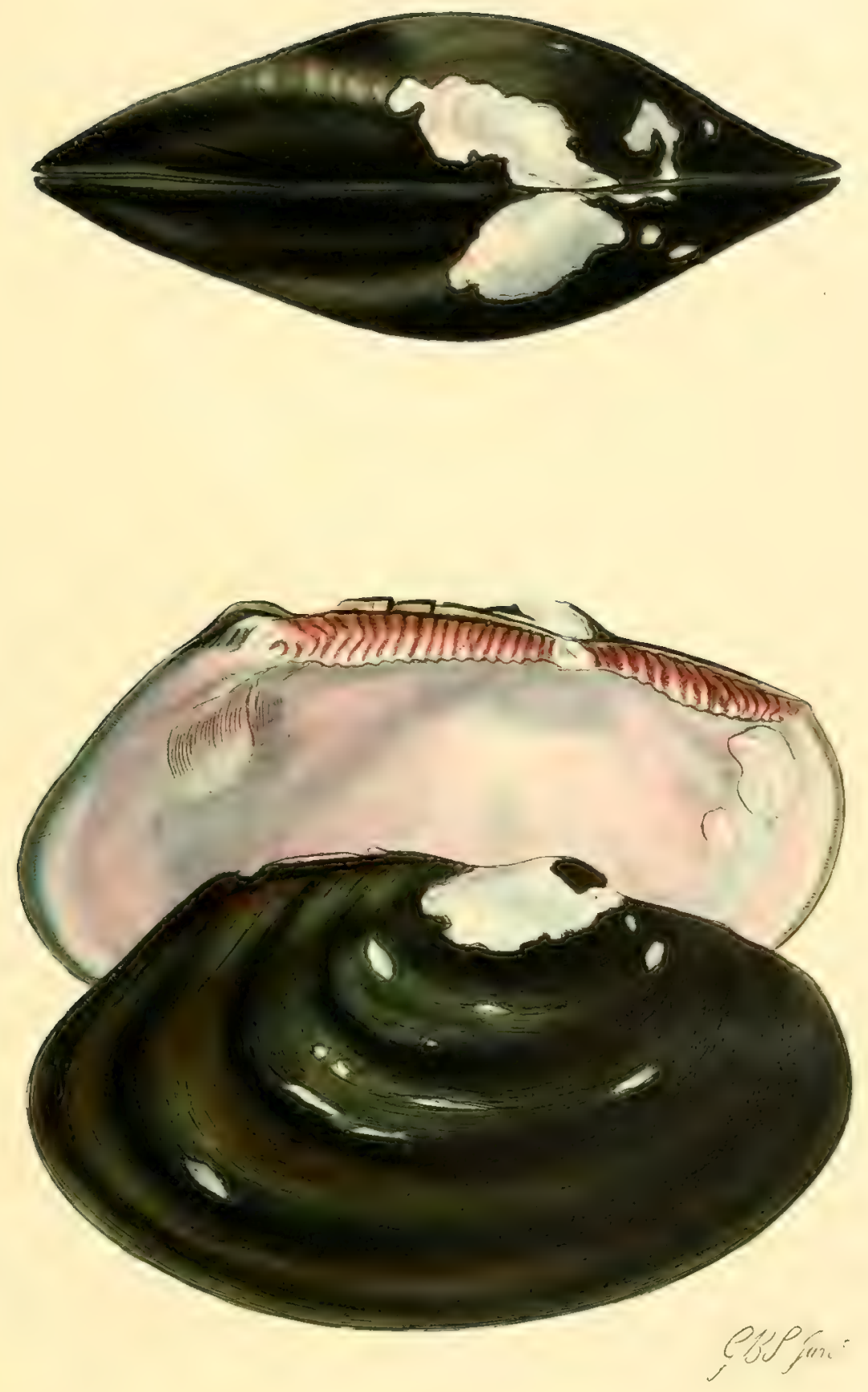



\section{MYCETOPUS, D'Orbigny.}

Testa tenuis, transversa, clongatissimo-cylindrica, subarcuata, aequivalvis, subxquilateralis, utrinque hians pracipuè ad extremitatem anticam, epidermide brunneo-viridescenti induta, intus carulescens; umbonibus centralibus, biangulosis, ad ipsos incurvis. Cardo linearis, rectus, edentulus ; ligamento tenui, marginali. Impressiones musculares subindistinctæ, compositæ.

The genus Mycetopus was introduced by D'Orbigny for the purpose of characterizing a new Huviatile mollusk inhabiting the rivers of South America. It was first discovered by him at Santa Cruz in the Republic of Bolivia; it is described in his 'Synopsis terrestrium et fluviatilium Molluscorum in suo per Americam Meridionalem itinere,' and figured in his 'Voyage dans l'Amérique Méridionale.' The Mycetopi have little aftinity with the Iridinc: the lobes of the mantle are free, and there are no siphons; their great peculiarity is in having a long extended cylindrical foot, inflated at the extremity, which they have not the power of withdrawing. By the assistance of this foot they are said to perforate like the Pholades; we cannot, however, venture upon this assertion until their characters and habits are satisfactorily known. We only place the Mycetopi in this family provisionally, because, after an accurate observation of the shell from which our figures are drawn, we are strongly inclined to think that they differ essentially from any other of the Naiades. Besides the peculiarity of the foot, there is a general tenor of character in the shell, especially in gaping widely at both ends, that seems to indicate a new organization in its animal inhabitant. The soleniform elongation of the valves, their tenuity, and the very central position of the umbones, are all mimute evidences of a change of character. For the present, however, we can but greneralize upon the slender information we are in possession of; for although there is a certain resemblance 
in the shell to that of many of the Naiades, we leave it under the impression that a future investigation of the animal will serve to establish its claim to a new and and separate family. Gray has indeed arranged the Mycetopi in a particular family, Mycetopodidc , but we anticipate a higher rank for these animals than that which is assigned to families in his method of classification; we cannot think that the propricty of distinguishing his Unionide and Iridimide as separate families, is equal to that of distinguishing his Unionide and Mycetopodide. The former are intimately allied by the Hyrice and Anodontes; but the latter are apart, and without their intermediate varieties*.

The shell of Mycetopus may be described as being thin, transverse, equivalve, nearly equilateral, and of a long cylindrical form, gaping at both ends, more particularly at the anterior. It is covered with a dark olivaceous epidermis, somewhat rubbed off townds the umbones, and the interior is lined with a slight nacre; the umbones are central, and turned directly inwards to each other. The hinge is linear, straight, and without teeth, furnished with a thin marginal ligament. The mus.

* In speaking of Gray's classification, it must not be supposed that we can fail to estimate his very skilful distribution of the Mollusca; as far as we are enabled to judge by his necessarily brief sketch of it in the 'Museum Synopsis,' it uppears to be based upon a careful obserration of the animal. We only object to his great extension of the nomenclature: we admire his arrangement, while we regret the introduction of such a confusing multiplicity of generic names; conceiving that it would far more promote the interest of science, if the elahorate cletail of his classification were carried out in the sectional subdivision of well-known genera, -in a language with which the world is familiar. The love of science is endangered when men of credit and ability arrogate to themselres the right of disturbing the received nomenclature; no new theories should be started, unless called for by the appearance of new phænomena. All this, however, might be allowed, if his system of arrangement were fairly illustrated by the great national collection of shells under his control; we might then appreciate his alterations, and be the very first to acknowledge the reasonableness and propriety of what now seems to come forth in the spirit of innovation. In the description and appropriation of what we call species, it is different; here every man may use his own fancy and discretion: his ingenuity of comparison is stretched to the utmost, because he cannot kcep pace with the creative force that is in operation; new forms are constantly making their appearance, because there is no limit to the creation of linds; and what is a species? the operations of Nature are infinite, - she does not clroose to be defined. 

MYCETOPUS.

Plate XCIV.
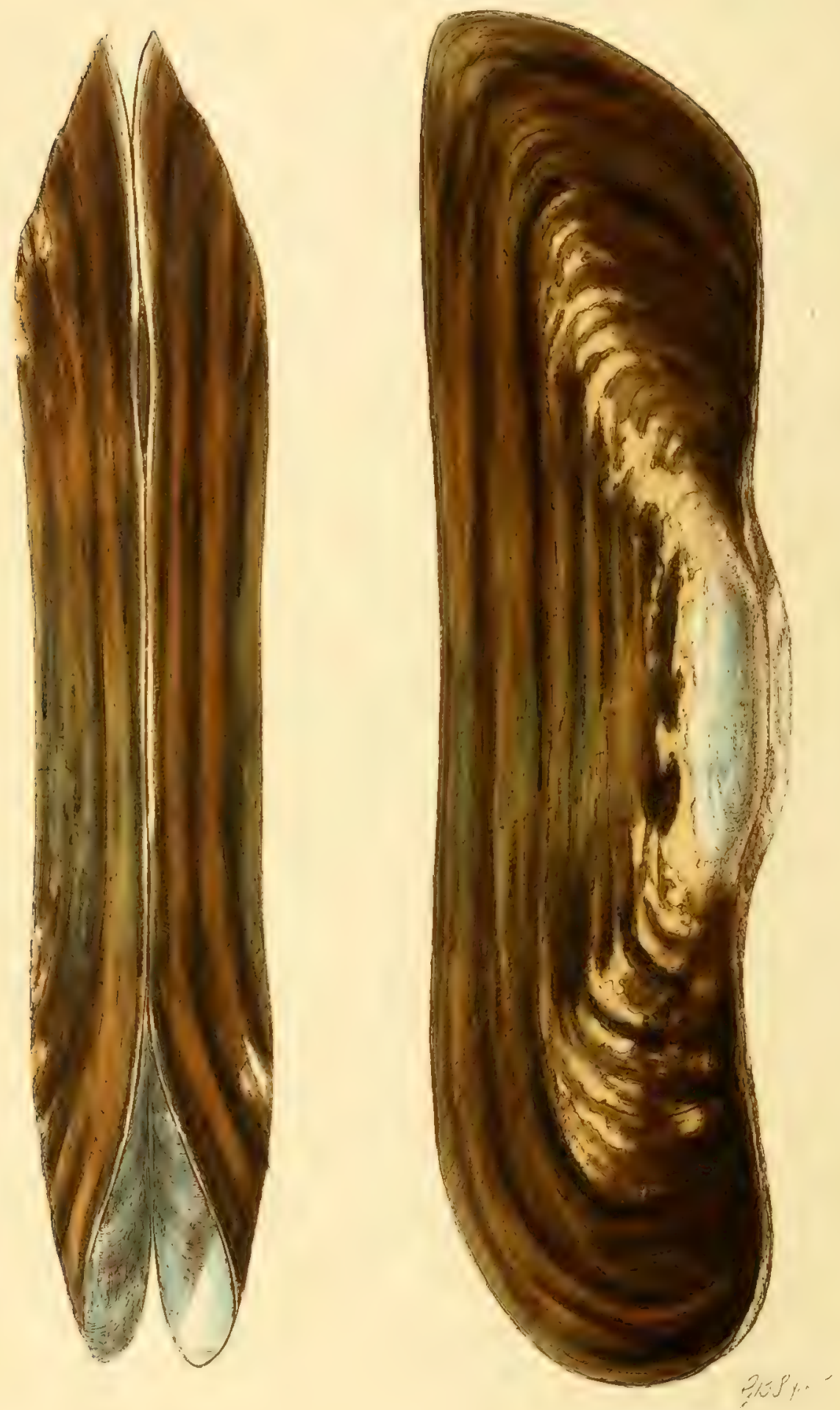
cular points of attachment are rather indistinct, being but faintly impressed; the anterior one is compound.

\section{Example.}

Pl. XCIV. Fig. 1 and 2.

Mrcetopus soleniformis, D’Orbigny, Magazin de Zoologie, 1835, p. 41 . Voyage dans l'Amérique Méridionale, Mollusques, pl. 66. f. 1 to 3. Mycetopus solenoides? Sowerby, Jun., Conch. Manual.

\section{Family 13. CHAMACEA.}

Testa inæquivalvis, irregularis, affixa ; cardine dente unico crasso, interdum obsoleto. Animal aut fluviatile aut marinum.

The important distinction as to whether the Tropiopodous mollusk is attached to its shell by one or two muscles, appears to have escaped the notice of Linneus; it is not, therefore, a matter of surprise that he should have associated in his grenus Chama both unimuscular and bimuscular species. Few of these are included in Lamarck's family of the Chamacea; some, as we have already shown (vide p. 101), are referred to the family of the Cardiacea, others to that of the Tridacnacea (Order II. Unimusculosa). There is, however, one of the two genera into which the Chamacea are divided, which we have not retained without considerable reluctance; in fact, it is only from a fear of being guilty of innoration that we have refrained from associating the Etherice in a new and separate family, or, rather, from regarding as families the divisions that are here deternined as genera. There is evidently a wide and unnatural gap in this part of the system; and we think it not improbable that new forms and varieties may yet be discovered, to reduce the apparent want of affinity between the Etherice and the Chamce.

The shell of the Chamacea is characterized as being irregular, inequivalve, and alvays attached by one valve to some other body. The hinge 
consists of a single solid tooth, but it is sometimes obsolete. Two genera? only are referred to this family; one is found to inhabit rivers, the othe? is peculiar to the sea.

$$
\begin{aligned}
& \text { Fluviatile. Etheria. } \\
& \text { Marine... Chama. }
\end{aligned}
$$

ETHERIA, Lamarck.

Testa irregularis, inxquivalvis, adhatens, periostraca crassa induta; internè glauco-viridis, submarearitacea, in vesiculas interdum inflatia ; umbonibus brevissimis, basi testie subimmersis. Cardo edentulus, undatus, subsinuosus, incepualis. Inpressiones musculares oblongat. unici interdum ferè obliterati. Ligamentum extcrnum, contortum, intùs partim penetrans.

The genus Etheria represents a small group of mollusks inhabiting the great rivers of Central Africal, having a shell somewhat like that of the Ostree ; they differ, howerer, not only in being fluviatile, but in having two internal muscles of attachment. They were but little known to Lamarck; he pronounced them to be marine, and ventures to assert that they had escaped the notice of travellers on account of their living attached to rocks at a considerable depth under water. When the Etheria were described by Sorrerby in his 'Genera of Shells,' the animal was still unknown, but from certain appearances on the shell he strongly suspected it to be an inhabitant of fresh water. His suspicions were laudably founded: in the first place, upon the shell being much eroded, like that of the Nuiades; and, secondly, upon the outer surface being often covered with the remains of those ovate, vesicular bodies so frequently seen upon Neritina, \&c., supposed to be the eggs of other freshwater mollusks. This conjectural opinion has been singularly confirmed by later discoreries; the Etherix have been found by Rang in the rivers of 

P'ate XCV.
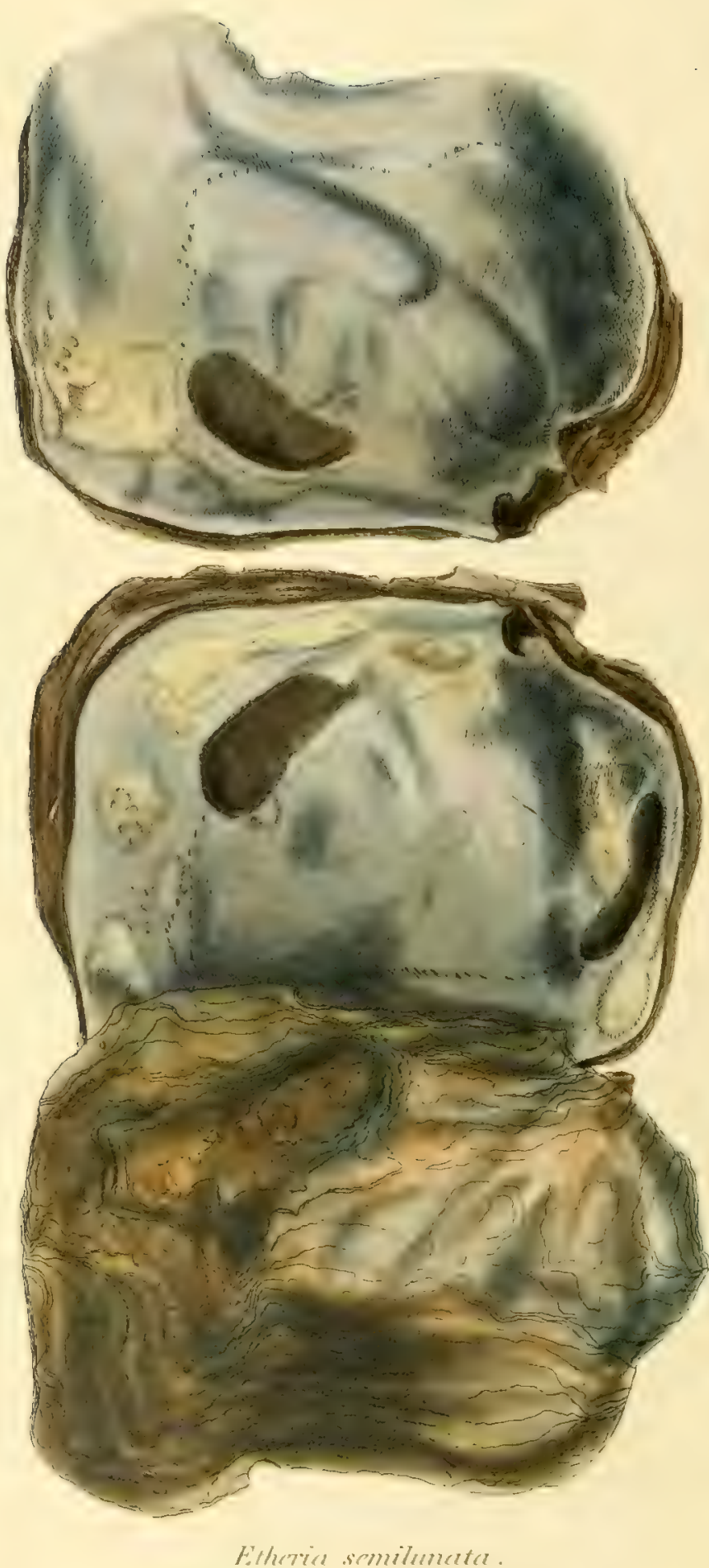
Senegal, and by Cailliaud in the Nile, as high up as the cataracts of Robattìs in Upper Nubia. They are described by the latter in his 'Voyagge à Méroé' as being a common article of food, and their shells are said to be collected by the natives for the purpose of decorating their tombs. The discovery of these curious mollusks at a considerable distance from the sea, entirely refuting the postulate observations of Lamarck, induced some interesting notices from De Férussac, Cailliaud and Rang, the last of whom describes them as being somewhat allied to the Nuiudes. They differ, however, materially in their habits and manner of growth: being found in small clusters, they adhere firmly to each other, presenting the most singular distortions of form; and the nacre lining the interior, which is not iridescent, is generally of a livid green colour, often raised in small blisters. The periostraca or outer coating is sometimes covered with irregular short spines; but this is inconstant, and varies in individuals of the same species.

The shell of Etheria may be described as being irregular, inequivalve, fixed, and covered with a thick periostraca, which is generally much eroded. The interior is somewhat pearly, of a glaucous green colour, but not iridescent, and the nacre is sometimes raised in small blisters, said to be formed when the mantle of the animal becomes irritated by the accidental introduction of small particles of sand during the secretion of the nacreous fluid. The umbones are very short, and almost lost in the increase of the shell. The hinge, which is entirely destitute of teeth, is smooth, unequal, and somewhat sinuous. The muscular impressions are of an oblong form, and one of them is often partially obliterated. The liggament is external, but twisted, and partially penetrating within.

The genus Mulleria of De Férussac was described from a specimen of Etheria, in which one of the muscular impressions was probably obliterated.

\section{Example.}

Pl. XCV. Fig. 1 and 2.

Etheria semilunata, Lamarck, Ann. du Mus., pl.32. f. 1 and 2. Anim. sans vert., new edit., vol. vi. p. 595. Deshayes, Enc. Méth. 
vers, vol. ii. p. 121. De Blainville, Manuel de Malacologie, p. 543.

Var. Etheria plumbea, De Férussac.

Var. (spinosa) Etheria Carteroni, Michelin.

\section{CHAMA, Linnæus.}

Testa irregularis, plerumque suborbicularis, inæequivalvis, adhærens; umbonibus inæequalibus, distantibus, involutis. Cardo dente unico crasso, obliquo, subcrenato, in fossulâ valvac oppositæe inserto. Ligamentum externum, divaricatum, sub umbonibus revolutum.

Bruguière was the first to reform the Linnean genus Chama, and it is now reserved only for those well-known parasitical species so frequently found adhering to the shells of other mollusks. The Chama have for the most part a delicately coloured shell, ornamented with numerous spines or foliations; but it is often much distorted, according to the situation in which it is confined. They become attached either by the upper or lower valve, and grow very irregularly, with the umbones turned either to the right or to the left.

The shell of Chama may be described as being irregular, generally suborbicular, inequivalve, and is always found adhering to some marine body; the umbones are unequal, distant, and turned inwards either to the right or to the left. The hinge consists of a single thick oblique tooth, which is a little crenated, and inserted in a small pit in the opposite valve. The ligament is external, divaricate, and rolled back under the umbones.

Examples.

Pl. XCVI. Fig. 1.

Chama Damecornis, Lamarck, Anim. sans vert., new edit., vol. vi. p. 580. Enc. Méth., pl. 197. f. 1, $a, b, c$. 
Yate XOVI.

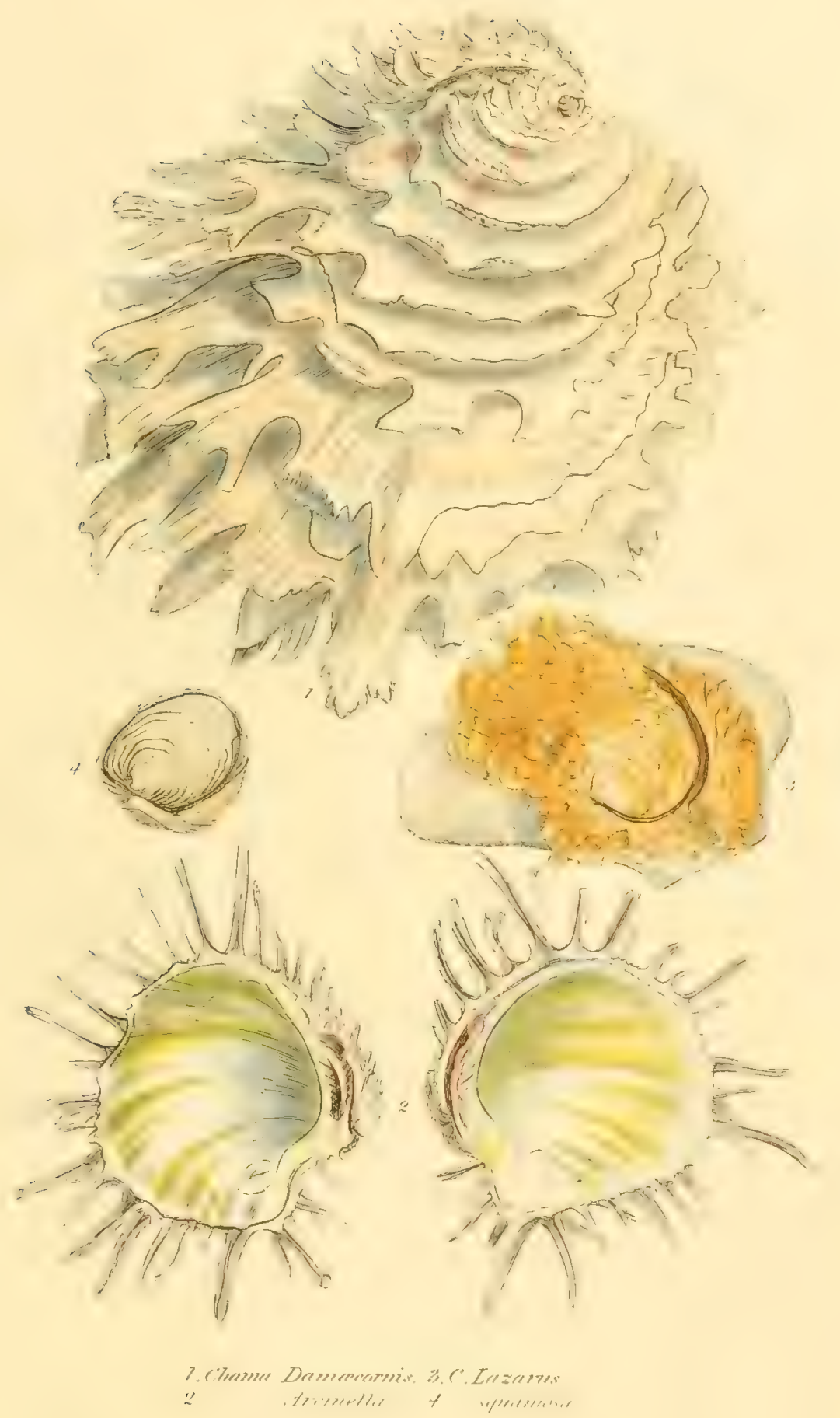



Pl. XCVI. Fig. 2.

Chama Arcinella, Linnicus, Syst. Nat., p. 1139. Lamarck, Anim. sans vert., new edit., vol. vi. p. 584. Enc. Méth., pl. 197. f. 4, $a, b$. Arcinella spinosa, Schumacher.

\section{Pl. XCVI. Fig. 3.}

Chama Lazarus, Lamarck, Anim. sans vert., new edit., vol, vi. p. 579. Enc. Méth., pl. 196. f。 4, 5.

Chama macrophylla, Chemnitz.

Chama gryphoides, Bruguière.

\section{Pl. XCVI. Fig. 4. (fossil.)}

Chama squamosa, Brand, Fossils, vol. vii. p. 86. Sowerby, Genera of Shells, No. 7. Enc. Méth., pl. 197. f. 2, $a, b, c$.

Chama lamellosa, Chemnitz. Lamarck.

Chama rugosa, Bruguière.

\section{Order II. TROPIOPODA UNIMUSCULOSA.}

Testa musculi inpressione unicĥ propè ad centrum internè imbuta. Animal interdum bysso affixum.

Lamarck appears to have been the first to notice the important character which serves to establish our primary division of the Tropiopoda. Before his time both the bimuscular and unimuscular species of this class were indiscriminately associated together; indeed in some instances, in one and the same genus. This method was certainly at variance with the true organization of the animal; and the additional advantage which the present arrangement offers, is that it is founded upon a character which may be determined without referring to the animal; the points of muscular attachment being always more or less distinctly discernible on the internal surface of the shell. Here, however, we meet with the difVoL. 1. 
ficulties that ever oppose our ingenuity to reduce the affinities of nature to an arbitrary division. The first two families of this order, the Tridacnacea and the Mytilacen, are said to be provided with a second muscle, distinctly figured both by Poli and Quoy, though very small and closely connected with the other. Deshayes, indeed, goes so far as to assert, that Lamarck might as well have included them with the Bimusculosa, and that the Tridacnacea are intimately allied to the Chamacea; we cannot, however, reconcile oursclves to this arrangement, because the animal of the former is somewhat opposed to that of the latter, being entirely reversed in its shell, with the foot passing out through the lunular opening under the umbones. We propose to consider this small additional muscle merely as an accessory cartilage, destined to strengthen the central muscle. The Triducnacea are animals requiring great muscular power, and the Mytiluce may require an accessory ligament to counteract the powerful action of the hinge ligament, with which their shell is provided in the absence of teeth. The Aticulacea, too, appear in some instances to possess several of these small accessory cartilagres: in the shell of the Aricula margaritifera (vide PI. CX.) a series of impressions of attachment may be distinctly traced running from the seat of the central muscle towards the hinge; and as in these several instances the animal is furnished with a beard or byssus, for the purpose of attaching itself to different marine bodies, may it not be also inferred, that these accessory cartilages are destined to assist the foot in fixing or displacing it? But a modification of this character may be traced in many of the Bimusculosa ; in the family of the Nuiudes, for instance, the muscular impression is said to be compound, when the shell exhibits any of these small accessory marks of attachment.

Lamarck includes the Brachiopodous Mollusca in this order; but subsequent discoveries hare confirmed the anticipations of Cuvier, that they have an organization essentially different. The elaborate investigation of these animals by Professor Owen has decided their claim to a separate and particular class.

The Unimuscular Tropiopoda, which are far less numerous than those of the former order, are divided into five families, as follows: 


$\begin{array}{ll}\text { Tridacnacea. } & \text { Pectinacea. } \\ \text { Mytilacea. } & \text { Ostracea. }\end{array}$

Aviculacea.

\section{Family 1. TRIDACNACEA.}

Testa solida, transversa, aquivalvis, lunulì plus minusve hians; marginibus ventralibus valvarum sinuosis, interclaudentibus. Impressio muscularis duplex aut bipartita, propè ad marginem amplè expansa. Animal bysso affixum.

The 'Tridacnacea exhibit a well-marked assemblage of characters, and may be readily distinguished. There are but few species, and each of them is intimately allied with the rest; so much so, that both De Blainville and Deshayes consider a further subdivision of this family unnecessary ; we propose, however, to follow Lamarck's plan of dividing the Tridacnacea into two genera.

Their shell may be described as being solid, transverse, equivalve, and more or less gaping at the lunula under the umbones; the ventral or outer margins of the valves being deeply sinuated and interclosing with each other. The muscular impression is duplex or bipartite, situated about the centre, and spreading nearly to the ventral margin.

The Tridacnacea are generally of large size, living attached to rocks and corals by a strong byssus; and, as they are generally found in exposed situations, are brought to this country in great abundance.

The following are the two genera into which this family is divided:

Tridacna.

Hippopus. 
TRIDACNA, Bruguière.

Testa regularis, æquivalvis, inæquilateralis, lunulît hians. Cardo dentibus duobus in utrîque valvî compressis, inæequalibus, anticis insertis. Impressio musculi adhærentis bipartita, subexpansa, propè ad marginem ventralem imbuta.

The genus Tridacna comes with great propriety at the commencement of this order, because of the duplex or bipartite construction of the adductor muscle; as it thus exhibits an indistinct modification of the two lateral muscles which characterize the former order. We confess that this affinity is rather forcibly stretched; still, as we have to lay out the Mollusca in systematic and comparative order, it becomes our duty to analyse, as far as possible, the affinities and relations of the several parts of the system. There most assuredly runs throughout the whole range of animated nature an unbroken link of connexion; it was a favourite maxim with Linnaus, "Natura non facit saltum;" and when we arrive at certain gaps in the chain, or, rather, at certain divisions in the general classification, between which it is difficult to establish an affinity, we can but ascribe the deficiency to the absence of existing forms yet remaining to be discovered. The naturalist endeavours, by the aid of certain symbols or characters, to reduce the objects of creation to comparative order; he establishes a series of artificial divisions of different rank, such as classes, orders, families, and so forth, to enable him to point to any given part of the arrangement ; and delights in the discovery of those forms which appear new, and most likely to diminish the gaps that remain open in a system, which he knows to be all-perfect.

The shell of Tridacna may be described as being regular, equivalve, disposed in ribs diverging in a longitudinal direction from the umbones to the margin; and the ribs are often covered with broad high-vaulted scales. The lunula situated on the dorsal part of the shell under the 

Plate XCVII.

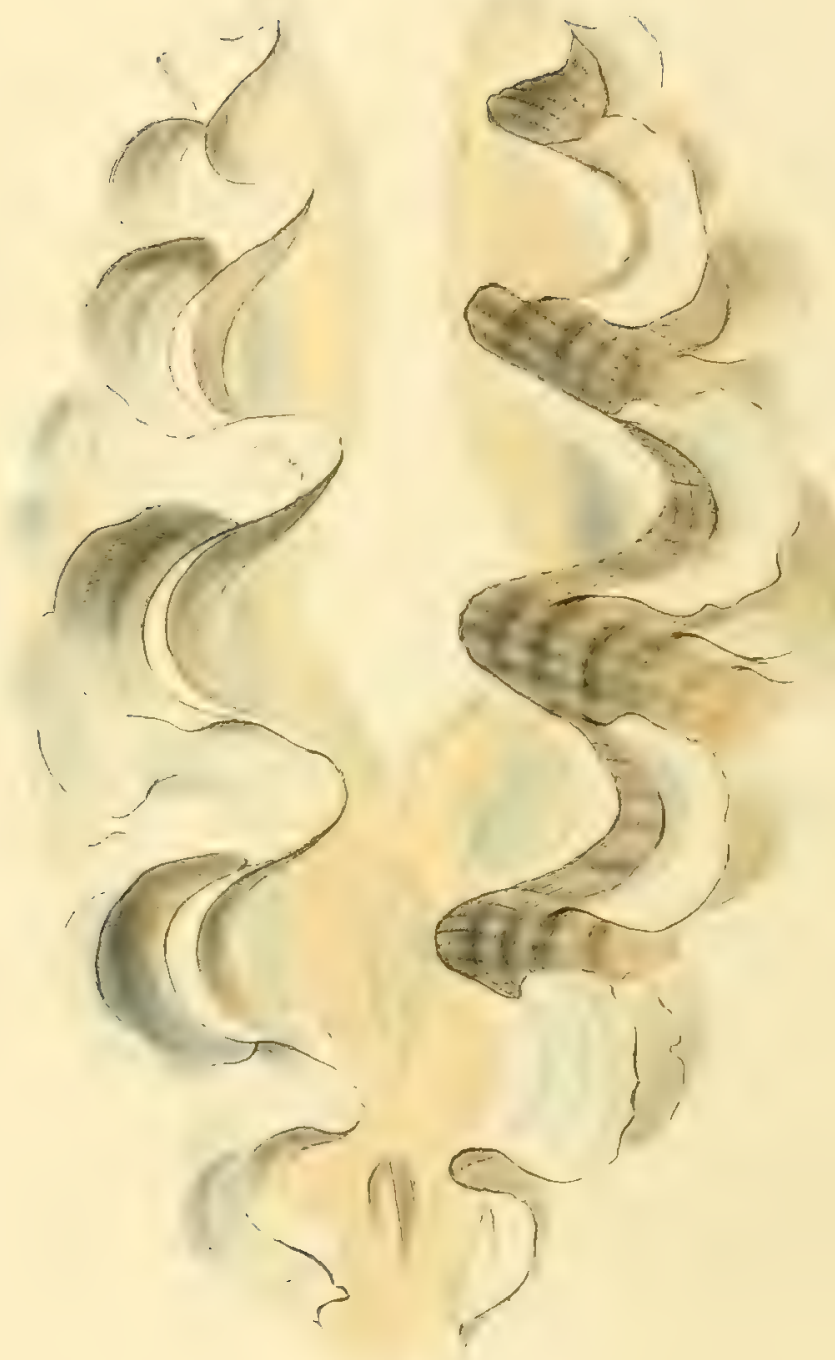


umbones is generally rather large, and has a wide opening for the passage of a strong tendinous byssus, by which the animal fixes itself to the rocks. The hinge has two blunt, unequal, compressed teeth in each valve, the anterior in one valve being inserted between those of the opposite valve. The interior of the shell is of an opalie marble-white, and exhibits the muscular impression spreading out torvards the ventral margin. The ligament is submarginal and external.

One species, the Tridacna gigas, is by far the most gigantic of all mollusks; it is said to possess immense muscular power, with a shell so large and ponderous as sometimes to exceed five hundred pounds in weight*

Example.

PI. XCVII. Fig. 1.

Tridacna elongata, Lamarck, Anim. sans vert., new edit,, vol. vii. p. 9 . Enc. Méth., pl. 235. f. 4.

HIPPOPUS, Lamarck.

Testa regularis, xquivalvis, inæequilateralis, extùs tuberculis numerosis imbricata; lunulâ ferè clausa. Cardo dentibus duobus in utrâque valvâ, compressis, inæqualibus, anticis insertis. Impressio musculi adhærentis subcentralis. Ligamentum externum, marginale.

Although the Tridacne and Hippopi were separated from the Chame by Klein under the title of Chamatrachea, Linneus continued to follow the arrangement of the earlier naturalists. Bruguière adopted the genus as proposed by Klein, substituting the appellation of Tridacna; but Latmarck, upon noting that the lunular opening for the passage of the foot

* The Tridacna gigas appears to be the lledwpias of the ancients: this title, which is used by Nicander (vide title-page) and some of the early Greek poets, is derived either from the word $\pi \epsilon \lambda$ íp the shell is found. 
was very wide in some, whilst in others it was nearly closed, established a still further subdivision. There are other peculiarities, however, in the shell of Hippopus which have induced us to retain this genus: the outer surface is curiously imbricated, and the interior is lined with clear white enamel, transparent as alabaster; the muscular impression, too, is not spread out towards the ventral margin, as in the shell of Tridacna. These, it may be said, are not very important differences, but they are peculiar and unchangeable; the size of the lunular opening cannot be entirely relied on as a generic character, but in this genus it never varies, being always very small, whilst in the genus Tridacna it is generally very large. In fact, it is only in the shell of the great Tridacna gigas that the lunular opening is known to be nearly filled up; and this arises from the excessive increase of the valves, which may probably require centuries to complete their growth.

The shell of Hippopus may be described as being regular, equivalve, incquilateral, and imbricated on the outside with numerous tubercles. There is but a slight opening in the lunula, the animal having a very small foot; and it is moreover not supposed to be furnished with any byssus. The hinge consists of two compressed unequal teeth in each valve, the anterior of which are inserted. The impression of the muscle is very nearly central, and the ligament is external and marginal.

\section{Examples. \\ Pl. XCVIII. Fig. 1.}

Hippopus Maculatus, Lamarck, Anim. sans vert., new edit., vol. vii. p. 12. Enc. Méth., pl. 236. f. 2, $a, b$.

Chama hippopus, Linnæus.

Tridacna hippopus, De Blainville.

Tridacua maculata, Quoy.

Hippopus brassica, Schumacher.

Pl. XCVIII. Fig. 2. (fossil.)

Hippopus avicularis, Sowerby, Genera of Shells, No. 13. 
Plate ICYIII
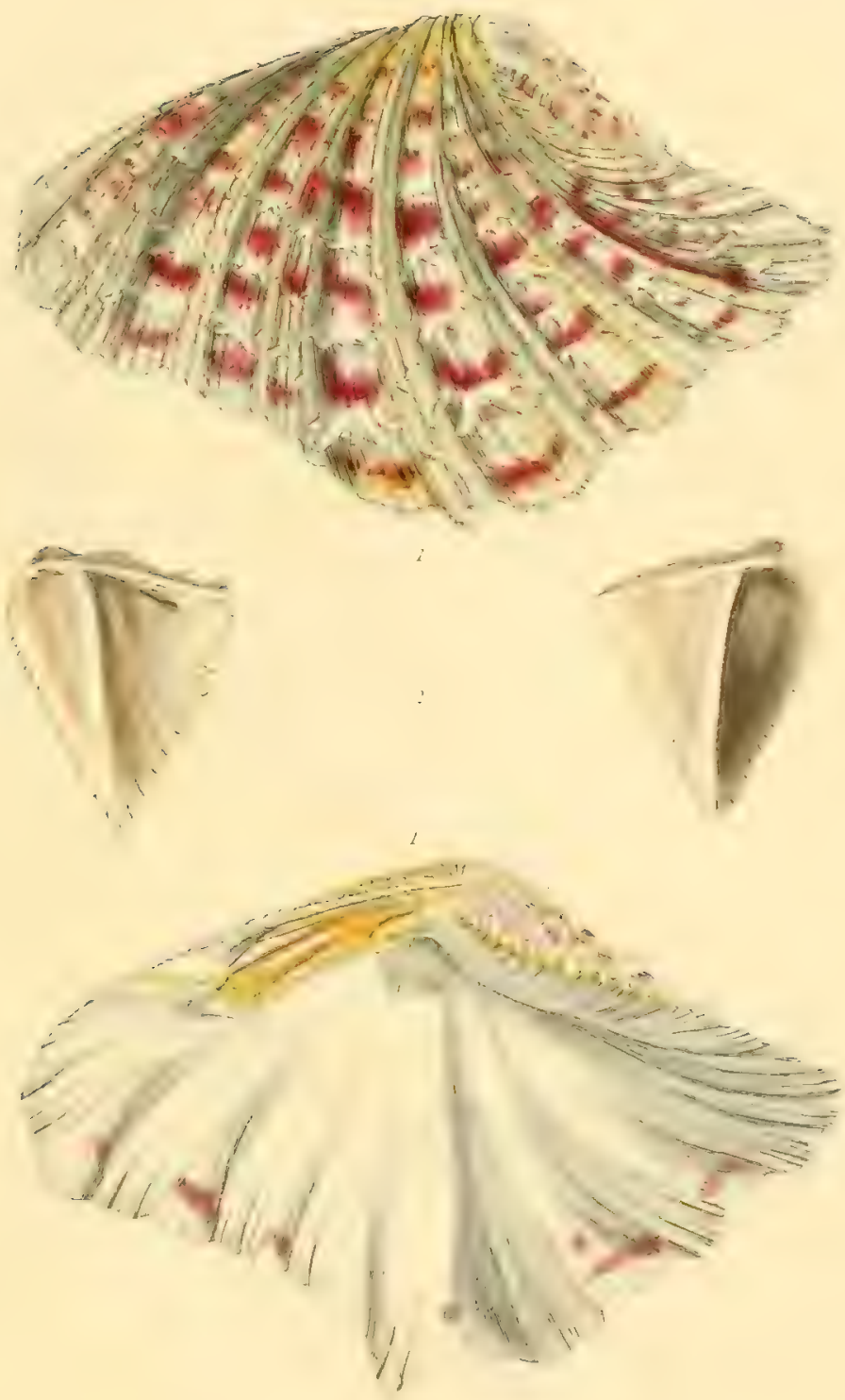

1. Huppopuss marelatus 



\section{Family 2. MYTILACEA.}

Testa sublonga, regularis, aequivalvis, plerumque lavis. Cardo edentulus, ligamento valido, lineari. Impressio muscularis composita. Animal bysso serico filatim affixum.

The Mytilacea have little affinity with the Tridacnacea, except in being provided with a byssus; and in this family that remarkable character, which is not found in all the Unimuscular Tropiopoda, is very fully developed. The byssus or beard consists of a number of filamentous or silken threads, by which the animal attaches itself to rocks or other marine bodies, and by the assistance of the foot it has the power of either fixing or displacing it. We may often observe the common muscles adhering to each other by their byssi; and in the Pinne, which often grow to an enormous size, the byssus has all the appearance of a large bunch of silk.

The shell of the Mytilacea may be described as being rather of an elongate form, regular, equivalve, and gencrally smooth. The hinge is entirely destitute of teeth, consisting merely of a strong marginal ligament. The muscular impression is compound, bearing the marks of one or more small accessory cartilages, probably destined to assist the muscle in counteracting the strong expanding power of the hinge ligament.

The family of the Mytilacea are divided into the four following genera :

$$
\begin{array}{ll}
\text { Lithodonus. } & \text { Mitilus. } \\
\text { Modiola. } & \text { Pinna. }
\end{array}
$$

\section{LITHODOMUS, Cuvier.}

Testa transversa, cylindraceo-oblonga, æquiralvis, epidermide fuscì induta; extremitatibus rotundatis, anticâ breviore; umbonibus vix 
prominulis. Cardo linearis, ligamento marginali, maximè interno. Impressio muscularis composita, indistincta. Animal bysso nullo?

The genus Lithodomus was introduced by Cuvier for the purpose of distinguishing a small group of tercbrating mollusks, previously included with the Modiolec. From a certain resemblance in their shell to that of Modiolu, Lamarck, and even some authors of the present day, consider this distinction unnecessary; but when we find two animals differing so entirely in their habits, the one living in the sea, attached by a byssus to submarine rocks, the other without occasion for a byssus, dwelling in concealed cavities of rocks resulting from its own mechanical contrivance; is it not probable that nature has given to each a corresponding and peculiar system of organization?

The Lithodomi are evidently terebrating animals, being found buried in stone, madrepores, \&c., in all their different stages of growth: their shell may be described as being transverse, cylindrically oblong, equivalve, and covered with a brown epidermis; the extremities, the anterior of which is much the shorter, are round; and the umbones are scarcely prominent. The hinge is linear, having a long marginal ligament, which is mostly internal. The muscular impression is compound and rather indistinct, and the animal does not appear to be provided with any byssus*.

\section{Examples.}

Pl. XCIX. Fig. 1 and 2.

Lithodonus dactylus, Cuvier, Règne Animal, vol. ii.p. 471. Enc. Méth., pl. 221. f. 6, 7. Sowerby, Genera of Shells, No. 23.

* Both Cuvier and Poli distinctly assert that the Lithodomi are provided with a byssus when young, and that previous to their operation of boring they adhere to the rocks like the rest of the Mytilacea. This assertion has, however, been contested by Sowerby, without reference to the animal, upon the following argument,-- that it is contrary to the nature of an animal to be at one time attached by a byssus and not at another. For our own part (though fully sensible of the caprice of Nature), we are strongly inclined to support the reasonableness of this opinion; and when it is a known fact, that the Lithodomi are as commonly found buried in stone in the very young as in the adult state, what further confirmation can be required? 
Plate XCTX.
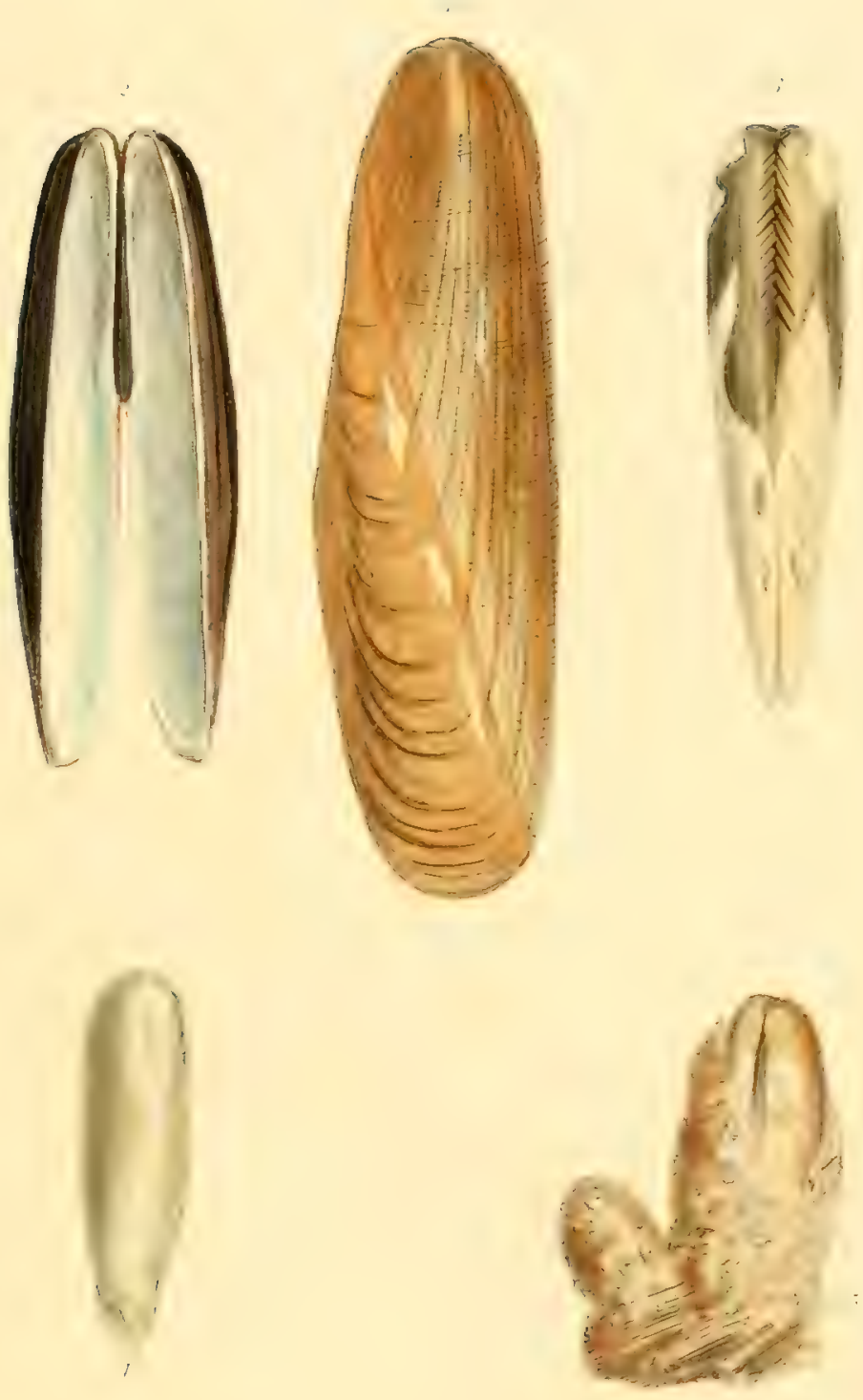

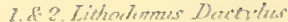

$3 d+f$ [...ner.e. 

Mytilus lithophagus, Linnæeus. De Blainville.

Modiola lithophaga, Lamarck.

Lithodomus lithophagus, Payrandeau.

Pl. XCIX. Fig. 3 and 4.

Lithodomus caudigerus, Sowerby, Genera of Shells, No. 23. Enc. Méth., pl. 221.f. 8.

Mytilus aristatus, Solander.

Mytilus caudigerus, Deshayes.

Modiola caudigera, Lamarck.

Pl. XCIX, Fig. 5.

(An undescribed fossil species in a Madrepore from the great Oolite.)

\section{MODIOLA, Lamarck.}

Testa oblonga, xquivalvis, regularis, inxquilateralis, latere antico brevissimo, obtuso, hiantulo. Cardo linearis ligamento marginali, subinterno. Impressio muscularis composita, sublateralis.

The Lithodomi, the Modiolx, and the Mytili are united both by De Blainville and Deshayes in one and the same genus. Lamarck unites the Lithodomi and the Modiola; but, for our own part, we consider that a much stronger affinity exists between the Modiolie and the Mytili; and if it had been advantageous to reduce the number of genera into which the Mytilacea are divided, we should certainly have rather decided on suppressing the genus under consideration. The Modiolæ entirely resemble the Mytili in their habits, and their shells differ only in the short obtuse termination of the anterior side; still, although they pass very nearly into the depressed longitudinally-triangular form of the latter, they may, nevertheless, be separated from them with tolerable accuracy. The shells of the Modiolie are well known; and when such is the case, 
we can feel the propriety of retaining a genus where we would not venture to create one; our object being to follow both the established nomenclature, and the poptular form of classification, as long as they accord with the progress of discovery.

The shell of Modiola may be described as being oblong, equivalve, regular and inequilateral, with the anterior side very short, obtuse, and a little gaping. The hinge is linear, consisting of a long, almost internal marginal ligament. The muscular impression is compound and sublateral.

$$
\begin{gathered}
\text { Examples. } \\
\text { Pl. C. Fig. } 1 .
\end{gathered}
$$

Míodiola picta, Lamarck, Anim. sans vert., vol. vii. p. 221. Enc. Méth., 1.1. 221 . f. 2 .

Mytilus arborescens, Chemnitz.

Mytilus pictus, Deshayes.

$$
\text { Pl. C. Fig. } 2 .
$$

Modiola silrecla, Lamarck, Anim. sans vert., vol. vii. p. 25. Sowerby, Genera of Shells, No. 26.

Mytilus siliculus (De Blainville?).

Mytilus cinnamomeus, var., Deshayes.

$$
\text { Pl. C. Fig. } 3 .
$$

Modiola discrepans, Lamarck, Anim. sans vert., vol. vii. p. 23. Payrandeau, Cat. Moll. de Corse, p. 67. Sowerby, Genera of Shells, No. 26.

Mytilus discors, Deshayes. Linnæus?

$$
\text { Pl. C. Fig. } 4 .
$$

Modiola discors, Lamarck, Anim. sans vert., vol. vii. p. 23. Enc. Méth., pl. 204. f. 5. $a, b$. Sowerby, Genera of Shells, No. 26.

Mytilus discors, var., Gmelin.

Mytilus cor, Martyn.

Mytilus impactus, Dillwyn. 


$$
e_{0}^{\infty}
$$






$$
\%
$$


PI. CI. Fig. 5.

Modiola tulipa, Lamarck, Anim. sans vert., vol. vii. p. 18. Enc. Méth., pl. 221.f. 1.

Mytilus modiolus? Linnæus.

Pl. CI. Fig. 6.

Modiola Semifusca, Lamarck, Anim. sans vert,, vol. vii. p. 22. Sowerby, Genera of Shells, No. 26.

Mytilus semifuscus (Deshayes?).

Pl. CI. Fig. 7.

Modiola plicatula, Lamarck, Anim. sans vert., vol. vii. p. 22. Enc. Méth., pl. 220. f. 5. $a, b$.

Mytilus plicatulus, Deshayes.

Mytilus demissus, Dillwyn.

MYTILUS, Linnæus.

Testa rquivalvis, obliqua, subtrigona vel cuneiformis ; umbonibus acutis, subrectis, terminalibus; latere postico rotundato. Cardo edentulus, rarò subcrenulatus, ligamento marginali, subinterno. Impressio muscularis composita, sublateralis.

The Mytili, as we have already shown, are so intinately allied to the Modiole, that many authors have thought it expedient to unite them. The former may, however, be recognized by the depressed and longitudinally-triangular form of their shell; whilst, in the latter, the shell is convex, and obtusely terminated on the anterior side. The Mytili are strictly marine; but one or two species, which have been carried into canals or docks through getting fixed to the bottoms of vessels, have become localized to fresh water. One of these, the Mytilus polymorphus, originally found by Pallas in the river Wolga, and described by him in т 2 
his 'Voyage en Russie,' is characterized as having a small septum, forming a cavity just beneath the umbo in each valve. The genus Dreissena is founded upon this feature, together with a slight modification of the animal; a similar indication may, however, be traced in some of the Pinnce and other Mytilacea.

The shell of Mytilus is described as being equivalve, oblique, and somewhat triangular or wedge-shaped; the umbones are acute, nearly straight, and terminal; and the shell is always rounded at the posterior side. There are no teeth, but in some species the hinge margin is a little crenulated, exhibiting an indication either of teeth, or of the crenulated ligamental pits which characterize the hinge of the Aviculaceu. The ligament is marginal and partly internal. The muscular impression is compound and sublateral.

\section{Examples.}

Pl. CII. Fig. 1.

Mrtilus achatinus, Lamarck, Anim. sans vert, new edit,, vol. vii. p. 45. Enc. Méth., pl. 218. f. 3.

Mytilus latus, Chemnitz.

Var. Mytilus versicolor, Gmelin.

Mytilus variegatus, Chemnitz.

\section{Pl. CII. Fig. 2.}

Mrtilus crenatus, Lamarck, Anim. sans vert, vol. vii. p. 38. Enc. Méth., pl. 217. f. 3.

Pl. CII. Fig. 3.

Mytrlus polymorphus, Pallas, Voy. en Russie, App., p. 211. Gmelin, p. 3363 .

Mytilus (e fluvio Volga), Chemnitz.

Dreissena polymorpha, Vanbeneden. Gray. 
Plate Cil.
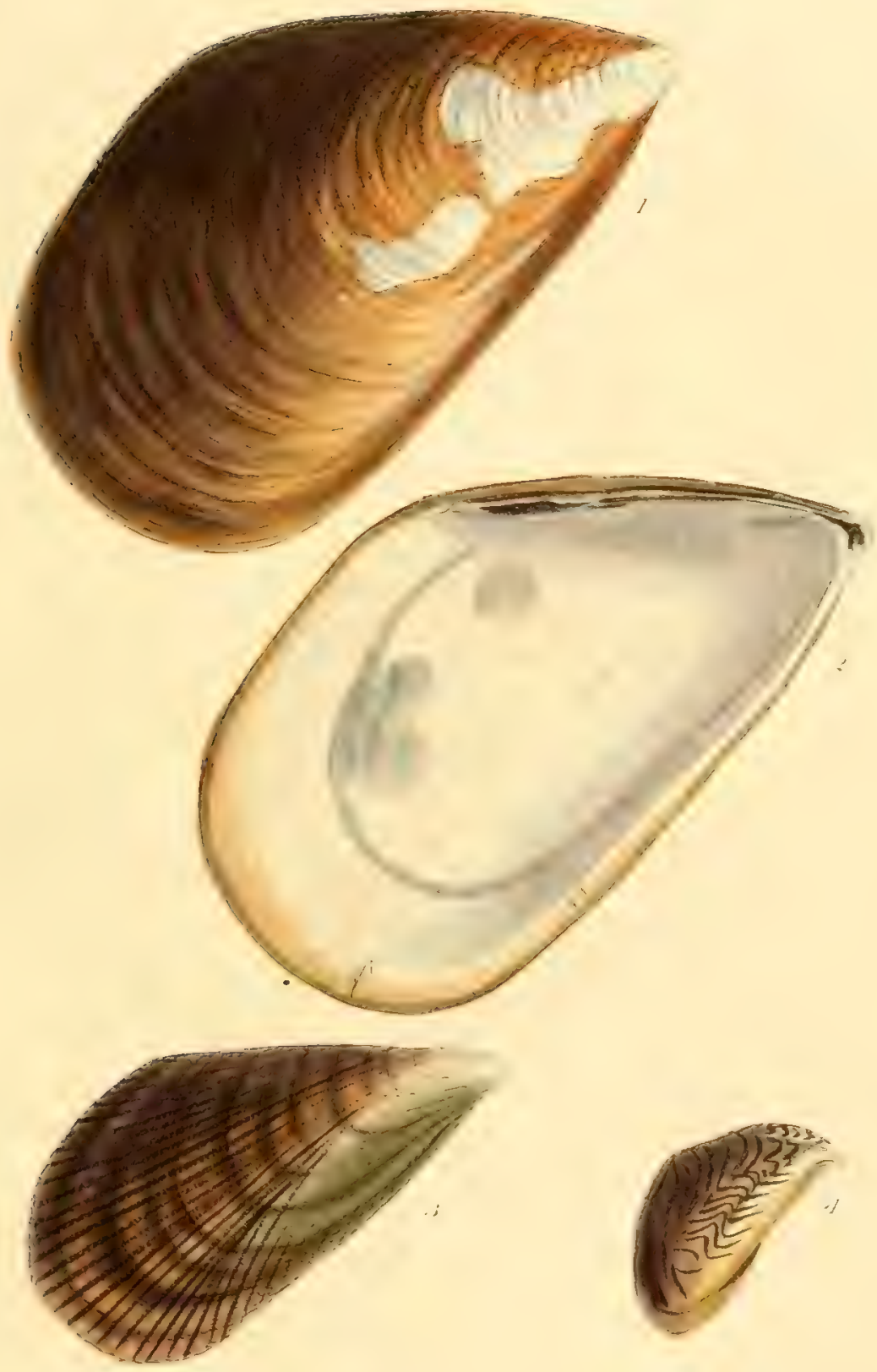

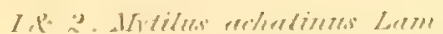

3 areserelus Leell

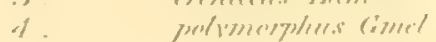





\section{PINNA auctorum.}

Testa aequivalvis, obliqua, cunciformis, longitudinalis, fibro-laminaris, extùs aut muricata, aut complanata ; umbonibus acutis, terminalibus ; lateribus, antico subhiantulo, postico sxpè valdè hiante. Cardo lateralis, edentulus, ligamento subinterno per totam longitudinem continuo. Impressio muscularis composita.

It is difficult to trace the precise origin of the present genus; the animals which it represents having been associated together in the natural system long before the time of Linneus. They appear, indeed, to have been well known to the ancients, and are described under the title of Minva by Aristotle, Oppian, Phyle, and other early historians. Although somewhat allied to the Mytili, they may be readily distinguished by the large size, and prisnatic crystalline texture of their shells; they differ also in having them often fretted with tubercles or blunted spines. What we have in the course of our descriptions of the Mytilacea termed the compound construction of the adductor muscle is especially marked in these animals; in fact, Poli, the celebrated Italian conchologist, who possessed great local advantages for examining the Pinne of the Mediterranean, has published an elaborate description of their anatomy, in which he asserts that there are two distinct muscles of attachment (vide Pl. CIV.). Still he admits that one is excecdingly small; we may therefore consider it (in accordance with the opinion of Lamarck, and without injury to the basis of our primary division of the Tropiopoda) as an accessory cartilage destined to assist the chief muscle in counteracting the powerful expanding action of the hinge ligament; we term it a compound muscle too, as analogous to the compound anterior muscle of some of the Bimusculosa. The genus Pinna is one of considerable interest, because we meet with a new and particular structure in the composition of the shell. Instead of being solid and 
entirely coated with a firm nacre, it is composed of a number of perpendicular fibres, disposed either in one laminal plate, or in several, one upon the other; and the nacre is only deposited in the central concavity of each valve, in the part occupied by the animal. This extended growth of the shell beyond the seat of animal existence is said to be very elastic during life, but when taken out of the water and dried it becomes hard and brittle. The shells of the Ariculacea have all this fibro-laminal structure, particularly those of the genus Avicula. The apical extremity of the valves is sometimes divided by a longitudinal suture, but this only occurs in one or two species.

The shell of Pinna may be described as being equivalve, oblique, wedge-shaped and longitudinal, having the outer surface either smooth or muricated; the umbones are acute and terminal ; the anterior side of the shell is a little gaping, but the posterior side often gapes widely. The hinge is lateral and without teeth; the ligament, which is partly internal, being continued throughout its entire length. The muscular impression is compound, as it exhibits the mark of a small anterior accessory cartilage. The Pinne have comparatively a large shell; their byssus is composed of fine glossy silken threads, and in some parts of Italy have been fancifully used in the manufacture of gloves. They are usually found partially buried in the sand, or in the crevices of rocks, with the pointed extremity of their shells downwards.

\section{Examples. \\ Pl. CIII.}

Pinna serrata, Solander, MSS. Sowerby, Genera of Shells, No. 26. Deshayes, new edit. of Lamarck, vol. vii. p. 67.

\section{Pl. CIV.}

Pinna nigrina, Lamarck, Anim. sans vert., new edit,, vol. vii. p. 66 . Enc. Méth., pl. 199. f. 1. $a, b$.

Pinna nigra, Chemnitz. 
Plate CIII.

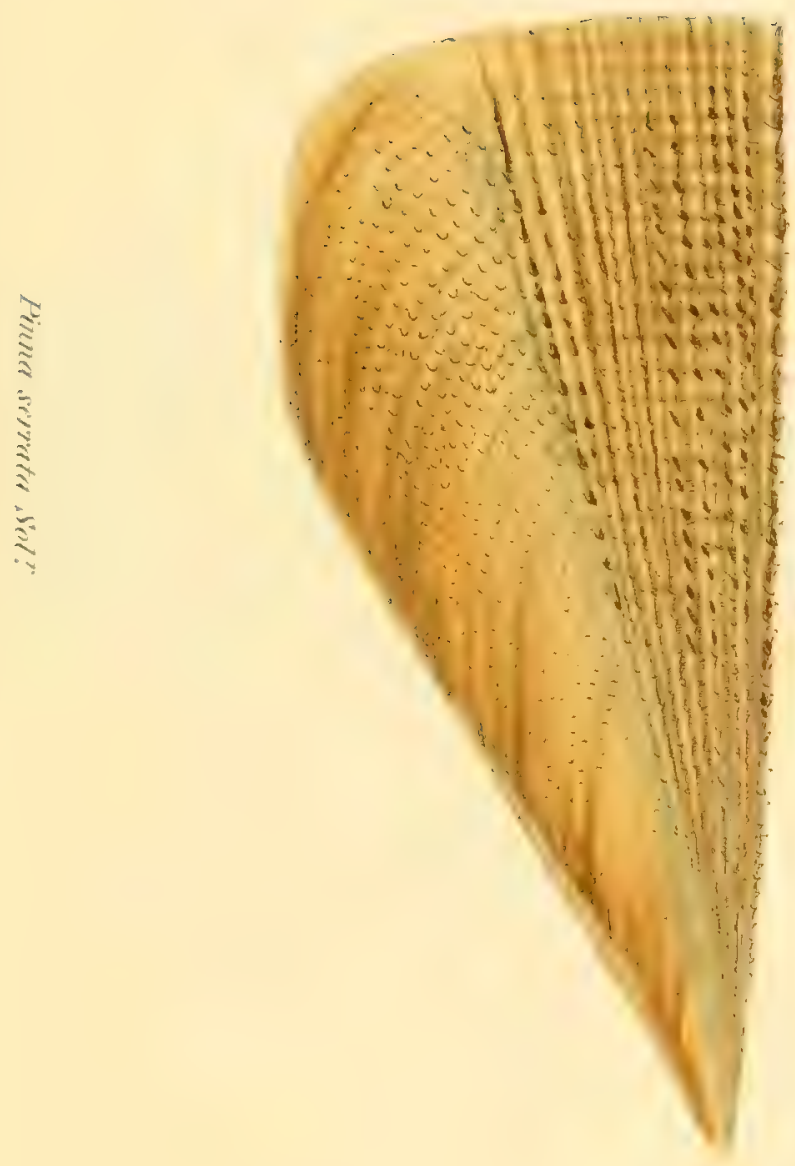



Plate CIV.

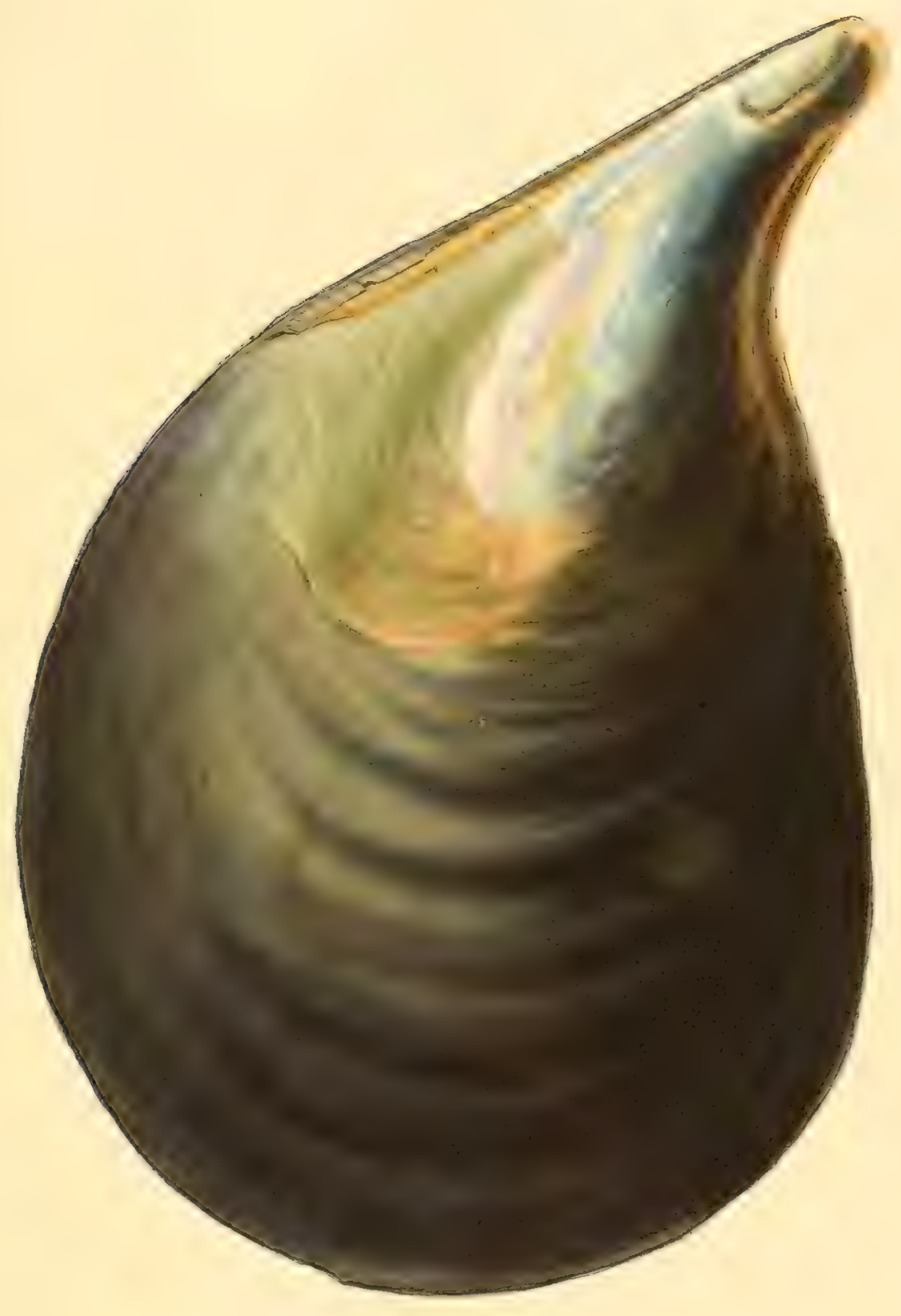

Pinlle minrine 



\section{Family 3. AVICULACEA.}

Testa irregularis, tenuis, fibro-laminaris, extùs interdum foliata. Cardo edentulus ligamento variabili, in fossulâ unicâ aut pluribus inserto. Impressio muscularis interdum composita. Animal bysso affixum.

Lamarck originally included the whole of the byssus-bearing mollusks in one family, Les Byssiferes; but upon noting the variety of forms that so extensive a series naturally included, he instituted the subdivision that has been since adopted. The Aviculacea are, perhaps, more variable in their general characters than any of the byssiferous Tropiopoda, and have yet undergone less change in their generic distribution from subsequent authors. They correspond entirely with Lamarck's family of Les Malleacées, except in the introduction of the genus Vulsella, which he included with the Ostracea; the Iulsella were removed by Cuvier on account of their affinity with the Mallei; the hinge is very similar, and they moreover differ from the Ostrea in being provided with a byssus, and therefore in not fixing themselves immediately by their shell. In this form the family of the Ariculacea is adopted by most author's: by De Blainville under the title of Margaritacea; by Latreille under that of Oxygona; and by De Férussac and Gray under that which we have here adopted. They come with great propriety after the Mytilacea, because their shells have the same peculiar fibro-laminal structure as those of the genus Pinna; they however differ from the Pinnce both in the position of the byssus, which passes out through a notch near the hinge, and in that of the ligament, which is inserted in one or more pits on the hinge margin. These ligamental pits vary considerably both in their shape and number, and chiefly serve to fix the subdivision of the family into genera. In some the hinge is characterized as having only a single central pit for the insertion of the ligament; in others it consists of a series of small concavities; and in others, again, of a series of parallel grooves. 
The shell of the Aviculacea may be described as being irregular, thin, fibro-laminal, and sometimes foliated on the outside. The hinge is edentulate, having a strong ligament inserted in one or more variously-shaped pits, and the muscular impression is sometimes compound. The animal fixes itself by a byssus, which passes out through a notch in the hinge or front margin. They are divided into five genera, as follows :

$\begin{array}{ll}\text { Crenatula. } & \text { Vulgella. } \\ \text { Perna. } & \text { Avicula. } \\ \text { Malleus. } & \end{array}$

CRENATULA, Lamarck.

Testa tenuis, subrequivalvis, complanata, fibro-laminaris, subirregularis.

Cardo lateralis, linearis, marginalis, crenulatus; crenis in seriem ordinatis, callosis subexcaratis, ligamentum excipientibus. Impressio muscularis oblonga, indistincta.

Lamarck and De Férussac both agree in placing the Crenatulæ at the commencement of this family, because of their affinity with the Pinna, the present genus being established by the first of these authors on account of a peculiarity in the hinge. In the shell of Pinna the hinge margin is simple; whilst in that of Crenatula it is so crenulated as to form a series of distinet concavities; each cardinal concavity contains a separate portion of the ligament, and thus forms a transition to the deep parallel grooves, so characteristic in the shell of Pcrna. There are several species of this interesting genus, one only of which appears to have been known to the early naturalists; by some it, was arranged with the Ostrere, by others with the Pinnce.

The shell of Crenatula may be described as being thin, nearly equivalve, smooth, fibro-laminar, and rather irregular. The hinge is lateral, 

Plate CV.
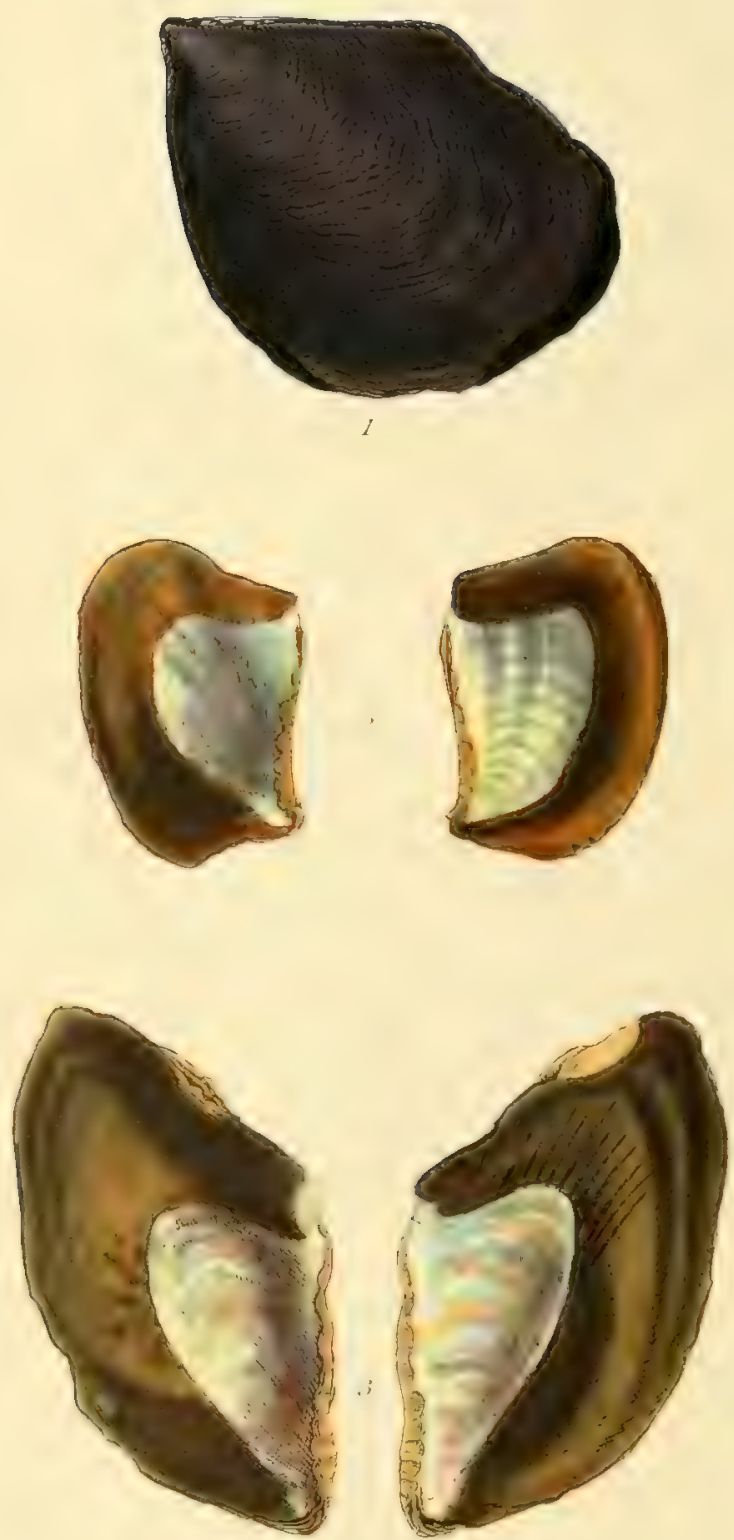

7.8.3 Cienatale mintaris

mitilondes 
linear, and crenulated along the margin; the crenula being set in a row so as to form a series of distinct concavities, cach containing a portion of the ligament. The muscular impression is of an oblong form, but rather indistinct. It has not yet been satisfactorily ascertained whether the Crenatula have any byssus; there is no visible sinus for the passage of it near the hinge, as in the shell of Perna; so, if it exists at all, we may conclude that it passes out at the ventral margin as in the case of the Pinne.

\section{Examples.}

Pl. CV. Fig. 1 and 3 .

Crenatula avicularis, Lamarck, Anim. sans vert., new edit, vol, vii.

p. 71. De Blainville, Manuel de Malacologie, pl. 63. f. 2. Ostrea semiaurita, Linnæus.

\section{Pl. CV. Fig. 2.}

Crenatula mytiloides, Lamarck, Anim. sans vert., new edit, vol. vii. p. 73. Annales du Mus., pl. 2. f. 3 and 4. Pinna picta? Forskael.

\section{PERNA, Lamarck.}

Testa planulata, fibro-laminaris, subæquivalvis, subirregularis, umbonibus parvis, subequalibus. Cardo latus, marginalis, sulcis plurimis parallelis in utrâque valvâ liratìm incisus; liris non insertis, sulcis ligamentum divisum inter se excipientibus. Lacuna specialis pro bysso infrà cardinis extremitatem posticam; parietibus incrassatis, æetate crescentibus. Impressio muscularis obliqua, distinctè imbuta.

Linnæus and his followers included the animals which come under our present consideration among the Ostrec. Lamarck appears to have been the first to separate them in the formation of the genus Perna; VOL. I. 
and this arrangement has been universally adopted, not only on account of the existence of a byssus, but because of the marked peculiarity of structure which the shell exhibits in the hinge. The hinge consists of a broad flat surface in cach valve, cut across by a parallel series of grooves, in each of which, as in the hollow concavities in the shell of Crenatula, is inserted a separate portion of the ligament. The ridges which are left by the cutting of these grooves do not interlock, but shut flat upon each other, the ligament occupying the interstices. These, therefore, may be called ridges, not "sulciformed teeth," as described by Lamarck, as they are in no way analogous to the row of teeth which characterize the shells of the Aicucen (vide p. 10ti. The hinge of that family, however, differs so widely, that we should not have thought it necessary to refer to it, had not our attention been arrested by Lamarcli's erroneous application of the term "teeth" to the cardinal rideres in the shell of Perna. The drce and the Pema are totally distinct, whether as regards the growth and composition of the shell, or the habits and general anatomy of the animal; they are not indeed referable to the same natural order. The fibroplated structure of the shell of the Aviculacea is very characteristic in the present genus; the animal occupies but a small central portion of the valves, and the byssus passes through a notch on the posterior side of the hinge.

The shell of Perna may be described as being flat, fibro-laminar, nearly equivalve, and rather irregulin, the umbones being small and nearly equal. The hinge, which is broad and marginal, is divided into a number of parallel grooves, destined for the reception of the ligament; the valves are thus powerfully united, and give the animal but a limited sphere for the opening of its shell. There is almays a marked posterior sinus near the hinge for the passage of the byssus, and it is lined with hard layers of testaccous matter, which increase with the growth of the shell. The muscular impression is of an oblique form, and generally distinct.

The Pernæ are very prolific, and are often found in considerable clusters attached firmly to each other by their byssi. 

Plate CVI.
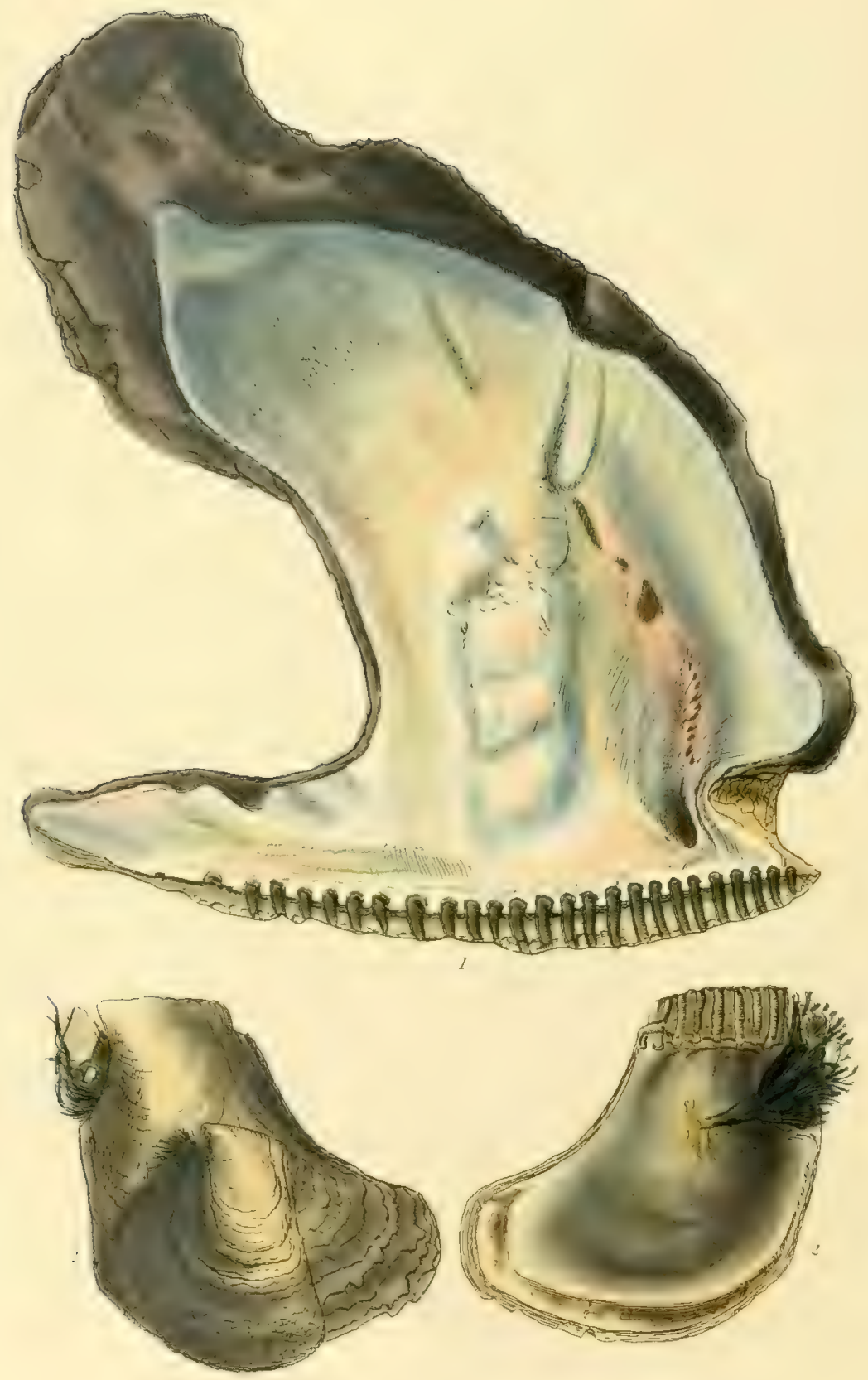

2. Pema Isamomzern

Epirizpriam 
Examples.

Pl. CVI, Fig. 1.

Perna Isognomu, Lamarck, Anim. sans vert., new edit., vol. vii. p. 75.

Enc. Méth., pl. 176. f. 1.

Ostrea Isognomum, Linnaus.

Perna femoralis, De Blainville.

Pl. CVI. Fig. 2.

Perna ephippium, Lamarck, Anim. sans vert., new edit., vol. vii. p. 74.

Enc. Méth., pl. 176. f. 2.

Ostrea ephippium, Linnæus.

MALLEUS, Lamarck.

Testa irregularis, deformis, subrquiralvis, ut plurimum elongata, ad basem sapissime utrinque lobata; lobis rectis, umbonibus divaricatis. Cardo edentulus, ligamento partìm cxterno in areâ declivi utriusque valvæe, partim interno in fossulâ trigonâ, centrali. Lacuna pro bysso in valvâ inferiori pone cardinem posita. Impressio muscularis composita.

When Bruguière dispersed the Limnzan Ostrece, the Mallei or Hammer Oysters were included amongst those which he proposed to associate under the generic title of Aricula. They were afterwards set apart by Lamarck for the formation of the present genus; and the appellation of Malleus was selected on account of the lateral lobes at the base of the shell giving it the appearance of an inverted hammer. This, however, only refers to the type of the genus; Linnæeus introduced the word malleus as a specific name, and in reference only to this particular species. It must not be supposed that Lamarck founded his new genus entirely upon the structure which its name implies, as there are one or two species of

$$
\text { บ } 2
$$


this genus that have little or no indication of the basal lobes (vide Pl. CVII. f. 2.). Our attention is again drawn to the hinge for a generic character: instead of the parallel grooves which characterize the shell of Perna, the hinge of Malleus consists of but a single central pit, protruding a little inwards, the ligament being partly inserted between the dorsal area of the valves, and partly in this central pit. The Mallei cannot well be confounded with any other genus: without reference to the presence or absence of the lateral lobes, they differ both from the Perna and the Ostrea, as we have already shown, in the structure of the hinge, and from the latter especially in being provided with a byssus.

The shell of Malleus may be described as being irregular, variously distorted, mostly elongated, and generally lobed on each side at the base ; the lobes are straight and the umbones divaricate. The hinge is destitute of teeth, and has the ligament partly external in an area behind the valves, and partly internal, within a small, central, triangular pit. The animal is provided with a strong byssus, which passes out through a notch in the lower valve behind the hinge. The muscular impression is compound.

\section{Examples.}

Pl. CVII. Fig. 1.

Malleus vulgaris, Lamarck, Anim. sans vert., new edit., vol. vii. p. 91. Enc. Méth., pl. 177.f. 12.

Ostrea malleus, Linnæus.

Pl. CVII. Fig. 2.

Malleus vormalis, Lamarck, Anim. sans vert., new edit., vol. vii. p. 92. Sowerby, Genera of Shells, No. 6.

\section{VULSELLA, Lamarck.}

Testa longitudinalis, fibro-laminaris, æequivalvis, subirregularis, umbonibus xqualibus. Callum cardinale in utràque valvâ prominulum, 
Plate CVII.

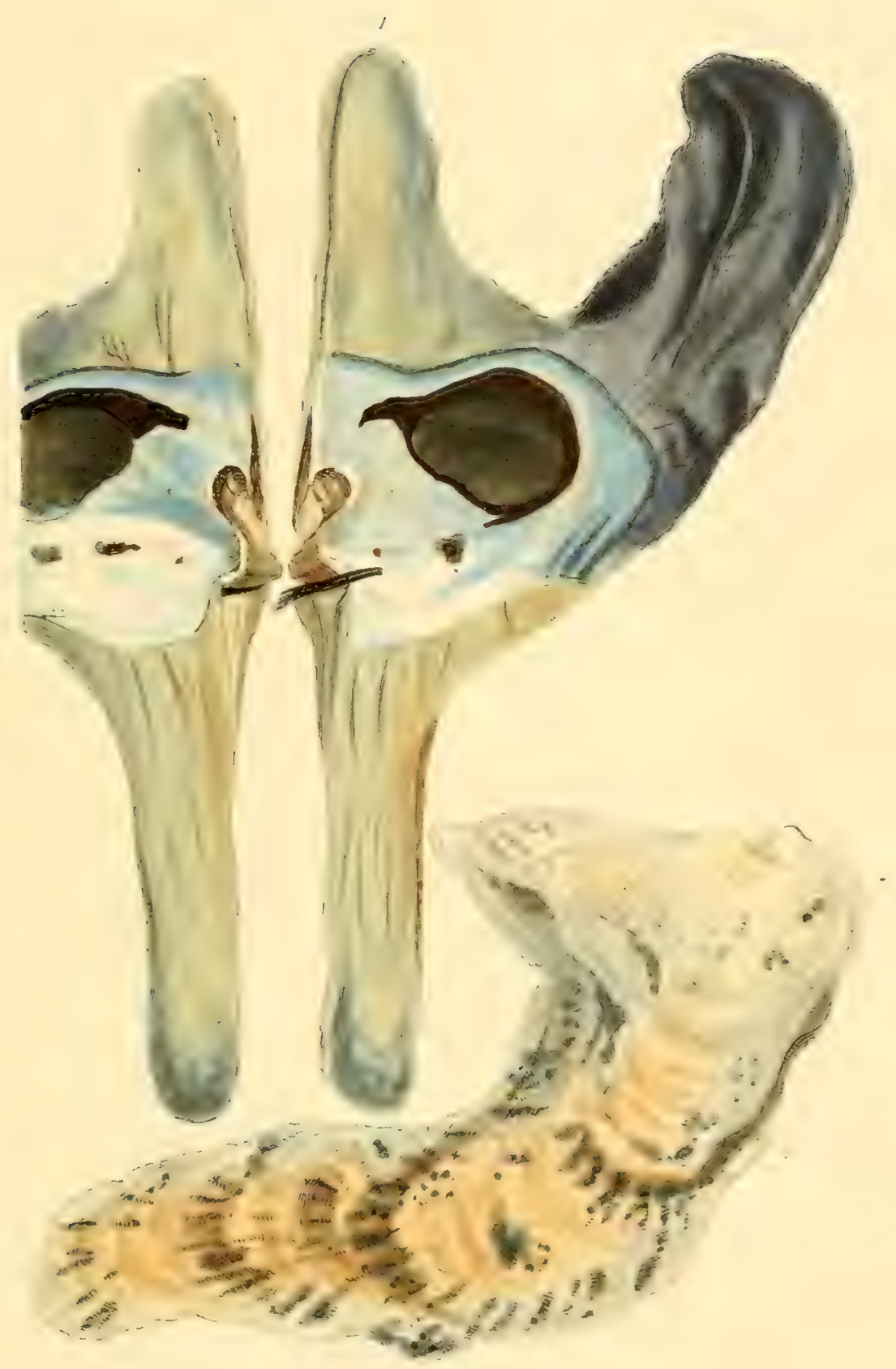

1. Malleas vulgaris

normalis 

supernè depressum, cum foveà conicà, obliquè arcuatì, desuper inpressum, ligamento inserto. Impressio muscularis subcentralis, propiùs ad basem distinctè imbuta.

We are certainly at a loss to determine why the great author of the 'Systema Natura' included the Vulsellie in his genus Mya, unless he supposed that some analogy existed between the prominent ligamentiferous process of the former, and the spoon-shaped tooth of the latter. They were placed by Bruguière, his immediate successor, in the genus Ostrea; and even Lamarck retained them in his fimily of 'Les Ostracées,' though separated from the Ostrece under a new generic title. Cuvier was the first to note the affinity that exists between the shell of the Vulsellax and that of the Mallei, he therefore removed them to their immediate vicinity; an improvement in the classification which subsequent authors have not failed to appreciate. Their shell is of the same thin fibro-laminal composition as that of the rest of the family, and the hinge is certainly a modification of that of Malleus. The Vulselle are generally found in sponges; the animal is still unknown, nor has it been yet ascertained whether it is provided with a byssus. From its peculiar mode of habitation, we can hardly be inclined to suppose that one is required.

The shell of Vulsella is described as being longitudinal or lingulate, equivalve and rather irregular, with the umbones equal. The ligament forming the hinge is partly external, attached to a groove, which crosses a somewhat depressed triangular disc; and partly internal, inserted in a conical obliquely-curved process or pit projecting within the valves; the muscular impression is oblong and subcentral, inclining towards the base of the shell.

This triangular disc or area is the commencement of a new character, arising from the manner in which the hollow of the ralves advance, as it were, with the increase of the shell, carrying the ligamentiferous process forward. The early growth then forms a kind of solid disc, showing the decayed remains of the original ligament in the groove which is left by the advance of the ligamentiferous process. This peculiarity of growth, however, is much more fully developed in the shells of the Pectinacea, in 
that of Spondyhus, for example: we shall, in our observations on that genus (vide p. 163), be provided with the means of showing it more distinctly.

Examples.

Pl. CVIII. Fig. 1 to 4.

Vulselia lingulata, Lamarck, Anim. sans vert, new edit, vol. vii. p. 267. Enc. Méth., pl. 178. f. 4. De Blainville, Manuel de Malacologie, pl. 62. f. 5.

Mya vulsella, Linnæus.

Ostrea vulsella, Bruguière.

\section{AVICULA, Klein.}

Testa irregularis, fibro-laminaris, iñequivalvis; basi transversâ, rectá, lateribus nommunquan brevibus, latere antico sepè admodum praxlongo. Lacuna pro bysso ad basem valvæ sinistræ. Cardo edentulus; sed tuberculo dentiformi in utrâque valvâ infra umbones plerumcue instructus. Area ligamentifera marginalis, linearis, angusta, in medio dilatata. Musculus compositus, impressione magni subcentrali, cxeteris minutis in seriem interruptam deorsim decurrentibus.

In accordance with the opinion of De Férussac, Sowerby, De Blainville, Deshayes and others, we include under the present genus both the Aviculie and Meleagrince of Lamarcli. The types of these divisions, when separately considered, are forcible and distinct; but their generic value is lost not only by the discovery of the intermediate varieties of their shells, but also, according to Poli, by a perfect analogy of organization in their animal inhabitants. The peculiar wing-shaped shell in the typical species of the first division attracted the attention of naturalists long before the time of Linnxus; they were described by these authors under the title of Cochlece ulifommes; and even that of Avicula may be traced as far back as Klein. Limnatu, however, included them with the Mytili; he was an enemy to 
Plate CVIII.

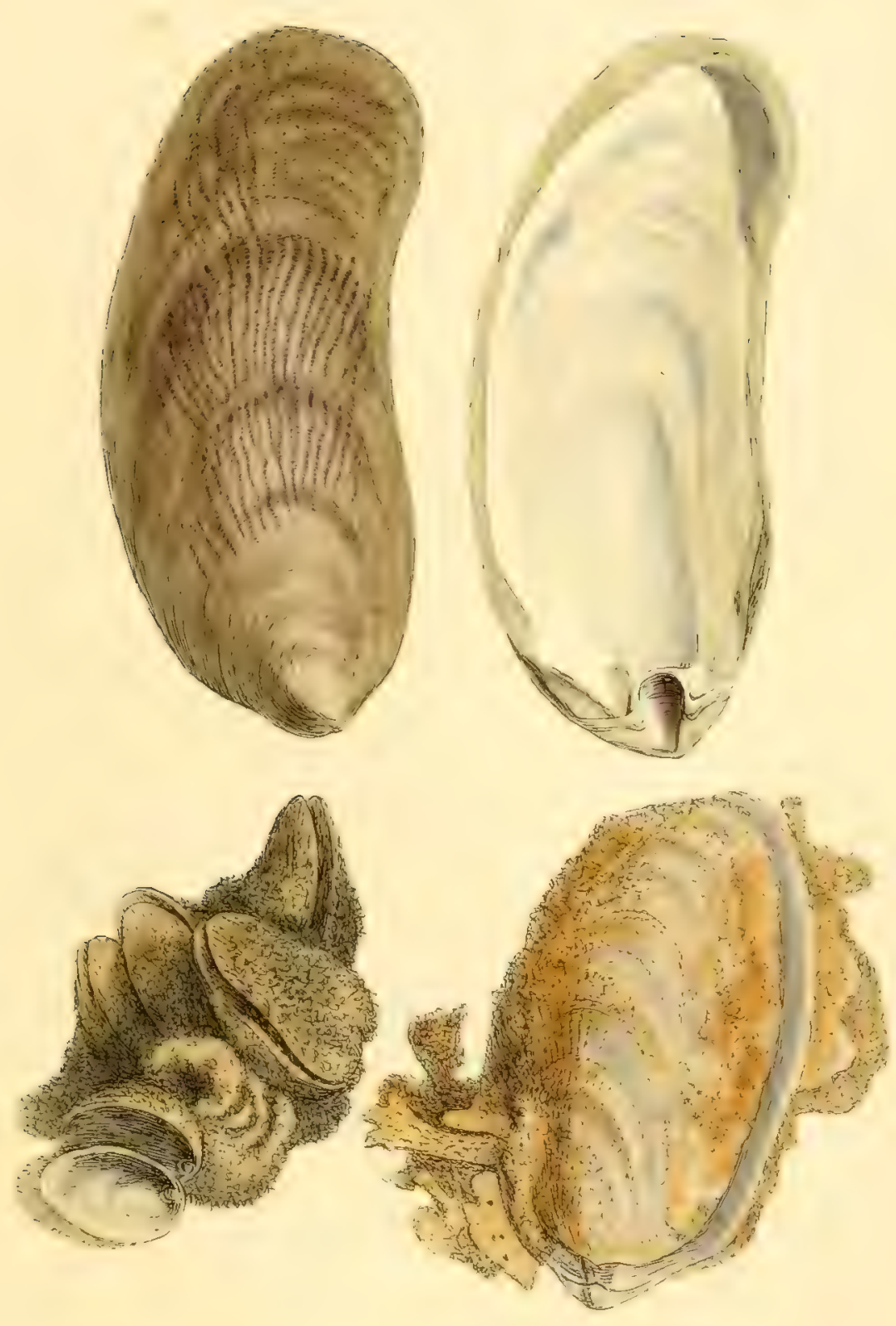

Vulsella lingulata. 

imnovation : in classifying the whole system of organic nature, both animal and regetable, this discreet naturalist had an immense scheme to contend with, and was therefore especially cautious in the introduction of new genera; still, whilst we esteem his operations for their simplicity and distinctness, we must admit that the efforts of speculators, such as Schumacher, De Montford and Gray, are useful and important when fully and fairly illustrated. The genus Aricula was then revived by Bruguière, including those species which Lamarck afterwards distinguished by the new title of Malleus.

The Aricula inerguritifere is that mollusk so celebrated for the production of the true Oriental pearl; the nacre with which it lines the interior of its shell exceeds that of all other species in lustre and brilliancy, and it is on this account that the pearls of this animal are so highly esteemed for their purity and beauty. Pearls are small nacreous balls, that become formed and hardened within the body of the animal; they are found deposited in the most fleshy parts, particularly within and around the adductor muscle, and are said to be occasioned by the overcharge of those glands, whose function it is to secrete the nacreous Huid destined for the internal lining of the shell. When the animal is thus diseased, this beautifully iridescent fluid is very irregularly discharged, being also deposited upon the imner surface of the shell in little heaps of hemispherical excrescences; these are often detached, and form articles of commerce as pearls of inferior value, the former being considered more precious both on account of their rotundity of form and the clearness and beauty of their complexion. The disease to which we are indebted for these valuable gems is very much increased by the introduction of a piece of stick or any sharp instrument within the shell, particularly if thrust into the animal in the fleshy parts of the mantle, or between the lobes. In fact, many of the proprietors of the Indian Pearl Fisheries preserve the Avicula margaritifere alive; they are said to keep large vivaria of them for the sole purpose of producing an inward accumulation of pearls by this cruel mode of irritation.

Pearls have been found in many other species of Mollusca; in all the Aviculacea, in the Tridacne, the Naiades, and even in the Haliotides 
(Class III. Gasteropoda. Family 3. Macrostomatu); in these animals, however, they are but rarely to be met with; and as their nacre is either opake or less iridescent, they are only preserved as curiosities. Pearls, therefore, are produced by a disease of the nacreous glands, resulting cither from accident, or from a supertuous discharge of the nacreous matter, which is more or less common to other mollusks, particularly the Unimuscular Tropiopoda ; and if the irritating process, before described, were similarly applied to other species, similar results would no doubt be produced. We refer our readers to the many published accounts of the Pearl Fisheries in the Indian and Chinese seas for a full history of the operations of the divers, \&c.

The shell of Avicula may be described as being irregular, fibro-laminar, sometimes forming beautifully imbricated scales, inequivalve, transverse, and straight at the base; the sides are sometimes short, the anterior often very long. The byssus pasies out through a notch at the base of the left ralve. The hinge is edentulate, but in most species an indication of teeth is offered by the appearance of a dentiform tubercle just beneath the unbo in each valve. The dorsal area of the valves which bears the ligament is marginal, linear, narrow, and somewhat dilated in the middle. The adductor muscle appears to be of compound construction, as there is generally an interrupted series of small marks, showing the attachment of certain accessory cartilages running from the large central impression down towards the umbones.

\section{Examples.}

Pl. CIX. Fig. ].

Avicula heteroptera, Lamarck, Anim. sans vert., new edit, vol. vii. p. 98. Sowerby, Genera of Shells, No. 14.

P1. CIX. Fig. 2.

Avicula aculeata, Sowerby, Genera of Shells, No 14.

Pl. CX.

Aviclla margaritifera, Bruguière, Enc. Méth., pl. 177.f. 144. Sow- 
Wate CIX.
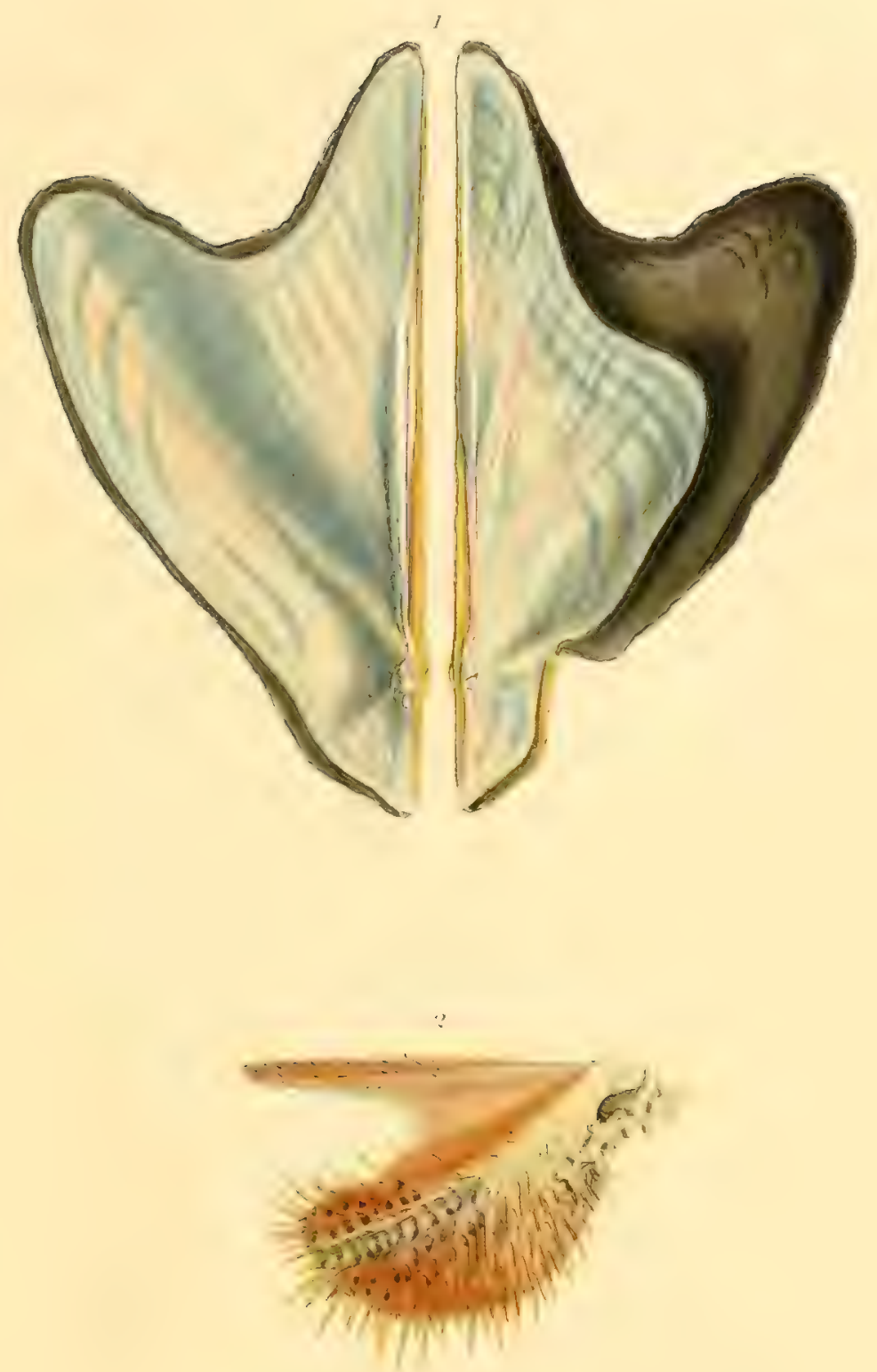

1. Arzinla heteroptera

2. ........... aculentat. 

$P:+, X$

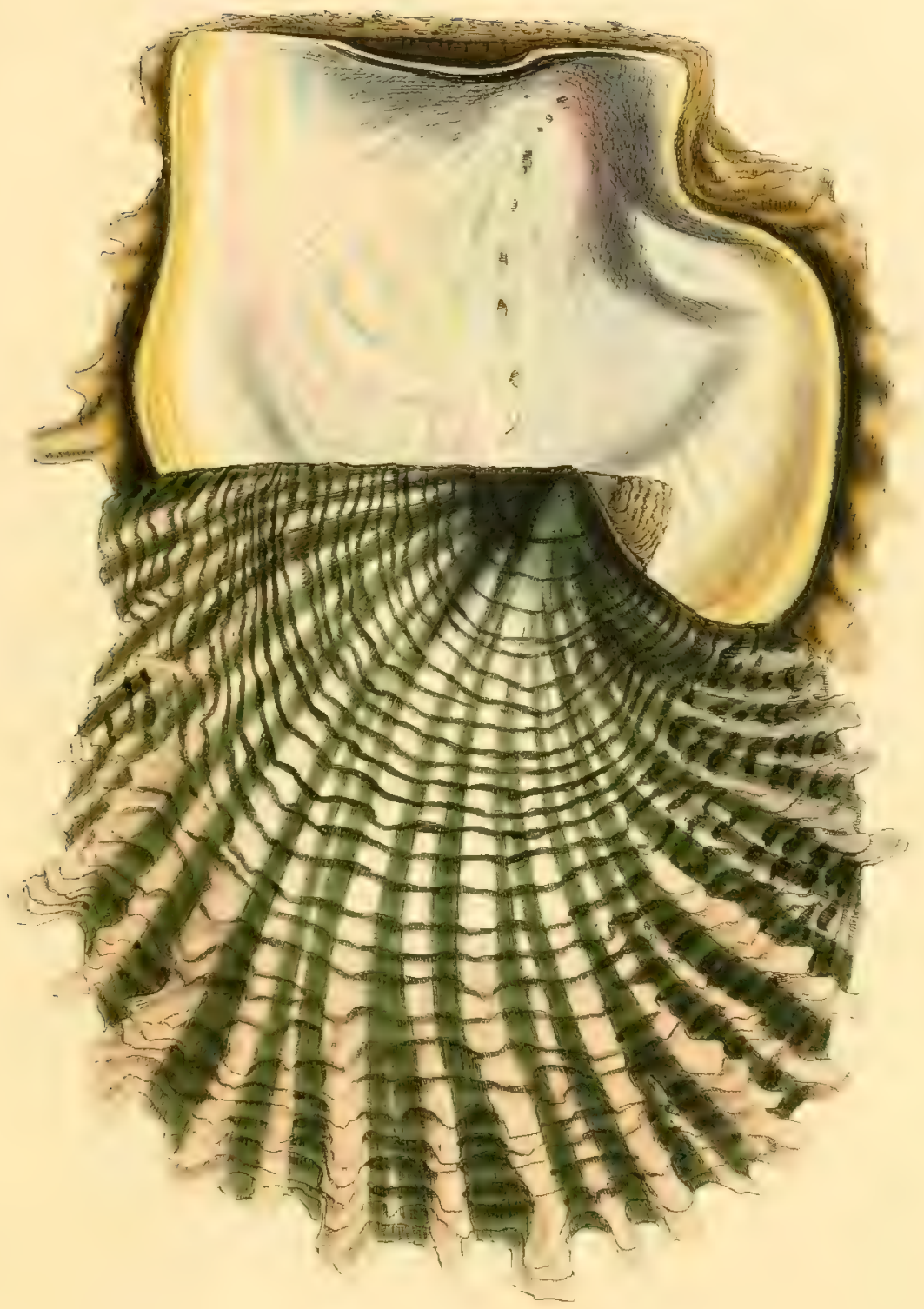



erby, Genera of Shells, No. 14. De Blainville, Manuel de Malacologie, pl. 65 bis, f. 7.

Mytilus margaritiferus, Linnæus.

Meleagrina margaritifera, Lamarck.

Margarita sinensis, Leach.

\section{Family 4. PEC'IINACEA.}

Testa vel libera vel affixa, sxuè inæquivalvis, subirregularis, plerumque ad basem utrinque auriculata. Ligamentum internum aut semi-internum, in fossulâ centrali insertum. Animal rarò bysso affixum.

The Pectinacea are an interesting and beautiful family of mollusks; their shells, especially those of the genera Pecten and Spondylus, exhibit a most lively display of colours, and have long been highly valued by collectors. They were originally included by Limarck in his family of 'Les Ostracées,' but he subsequently separated them under the title of 'Les Pectinides,' on account of the shell being generally auriculated at the base, with the valves radiated like a comb. De Blainville's family of the Subostracea is precisely the same; in fact, Lamarcli's distribution of the genera has been for the most part adopted by succeeding naturalists. We have still, however, a very considerable range of characters throughout the family of the Pectinacea: in the genus Pedum, for example, the animal attaches itself by a byssus, passing out, as in Perna, through a notch on one side of the hinge; and the shell is moreover strongly characterized by the dorsal area which the valves form as they advance in growth. Now, in the genus Pecten, this area or disc entirely disappears; the byssus is said to be very small, and the shell does not become attached, except in one single instance; this species too has been separated on that account as a distinct genus (Hinnites), and probably ought to remain so. In the genera immediately following, Plicatula and Spondylus, there is a new change of character in the appearance of strong cardinal teeth, and the dorsal area or disc is again very remarkable. When we VOL. I. 
consider, therefore, that such an opposite assemblage of characters is united in one family, we almost fear to have adhered too strictly to the classification of Lamarck in allowing it to remain. The method which Gray has introduced of separating the Spondylida, as having teeth, from the Pectinida which are edentulate, might certainly be adopted with advantage; we still uphold the former, however, because these divisions are so neatly linked the one to the other; the transition from Pecten to Spondylus through that species which has been distinguished by the generic title of Himites, together with Plicatula, is as perfect as it well can be; and we moreover retain the family of the Pectinacea, on the principle that no new data or phenomena, whether of form and variety in the shell, or of habit or organization in the animal, have appeared since it was established by Lamarck.

The shell of the Pectinacea may be described as being either free, or attached by one valve; it is often inequivalve, somewhat irregular, and generally auriculated at the base on each side. The ligament is either internal or semi-internal, inserted in a central pit or groove, and the animal is not always provided with a byssus. The Pectinacea are divided into five genera, as follows :

$\begin{array}{ll}\text { Pedum. } & \text { Plicatula. } \\ \text { Lima. } & \text { Spondyus. } \\ \text { Pecten. } & \end{array}$

PEDUM, Bruguière.

Testa longitudinalis vel elongato-securiformis, compressa, inæquivalvis, subauriculata; valvis in areâ trigonâ, xtate crescente, ad basem productis; valvâ inferiori convexiusculâ, lateribus reflexis, latere uno propè ad cardinem, byssi causâ profundè sinuato; valvâ superiori 



$$
\begin{aligned}
& 00 \\
& 80
\end{aligned}
$$


planiusculâ, lateribus simplicibus, subincrassatis. Cardo edentulus, ligamento interno, in fossulâ trigonâ, centrali, inserto.

The Pedum was arranged by Linnæus in his genus Ostrea; but, from the remarkable and peculiar construction of the shell, Bruguière was induced to distinguish it in the 'Encyclopédie Méthodique' by the above new generic title. In this he was quickly followed by Lamarck; and although the animal was still unknown, its shell presented so distinct an assemblage of characters, that no one could fail to appreciate the genus that was now fairly established. Since then the anatomy of the Pedum has been fully described by MM. Quoy and Gaimard in the "Voyage de l'Astrolabe,' and it singularly accords with what Lamarck had anticipated while placing it at the commencement of the family. The organization of this animal appears to be exactly intermediate between that of Avicula and Spondylus: like the former, it is provided with a strong tendinous byssus exserted in the same direction; and the shell, like that of the latter, no longer exhibiting that particular tibro-laminar structure, forms a solid umbonal area. Its habits, however, appear to differ considerably from both, as many of them were found by this indefatigable naturalist partially buried in Madrepores, in crevices of their own boring.

The shell of Pedum may be described as being longitudinal or elongately hatchet-shaped, inequivalve, and slightly auriculated; the valves are both produced at the base into a triangular disc, increasing with age, in the centre of which is a groove or pit, projecting inwardly for the reception of the ligament; the lower valve is rather convex, with the sides reflected over; but the upper valve is flattish, and simple or somewhat thickened at the sides.

\section{Example.}

Pl. CXI. Fig. 1 to 5.

Pedum Spondyloideum, Lamarck, Anim. sans vert., new edit, vol. vii. p. 112. Enc. Méth., pl. 178. f. 1. De Blainville, Manuel de Malacologie, pl. 62. f. 6. Quoy, Voyage de l'Astrolabe, Mollusques, pl. 76. f. 15 to 21 .

Ostrea Spondyloidea, Gmelin. 


\section{$L I M A$, Bruguière.}

Testa longitudinalis, subrquivalvis, inequilateralis, auriculata, latere uno sublians. Umbones diraricati, parietibus internis extrorsùm declivibus. Cardo edentulus, sed interdum ad utrumque latus indistincte crenulatus. Ligamentum partim externum, in medio arex obliqux, in fossulâ trigonâ insertum. Impressio musculi sublateralis.

The Limx, together with the Pectines, were placed originally in the genus Ostren on account of their shells being destitute of teeth; and in this situation they remained until Bruguière, the great reformer of the Limnain system, proposed the alteration that has been since adopted. Poli asserts that the Lima are intimately allied to the Avicula, both having a byssus, and actually proposes to unite them in one and the same genus, under the title of Glaucoderme. Lamarck, indeed, being persuaded that they were provided with a byssus, included the genus under consideration (probably on the authority of Poli) with Avicula in his family of Les Biyssiferes; but subsequently, on the formation of his family of Les Pectinides, he arranged the grenus Lima in the situation which is here assigned to it, and in which he has been followed by De Blainville, Gray, and most of the leading conchologists. Now, however, the propriety of arranging the Lime in the family of the Pectinacea has become rather questionable; Deshayes asserts that they differ materially in their organization from the Pectines, to which they have been latterly considered as most intimately allied, and that they ought indeed to constitute a new and particular family. This opinion appears to have been advanced on the anatomical observations of Quoy, - authority, which it is as painful to doubt, as it is difficult to dispute. Much as we respect the labours of this skilful malacologist, we must content ourselves by merely putting this opinion upon record: the shell of Lima does not certainly approximate to that of Pedum; there is no basal notch for the 

Plate CX11.

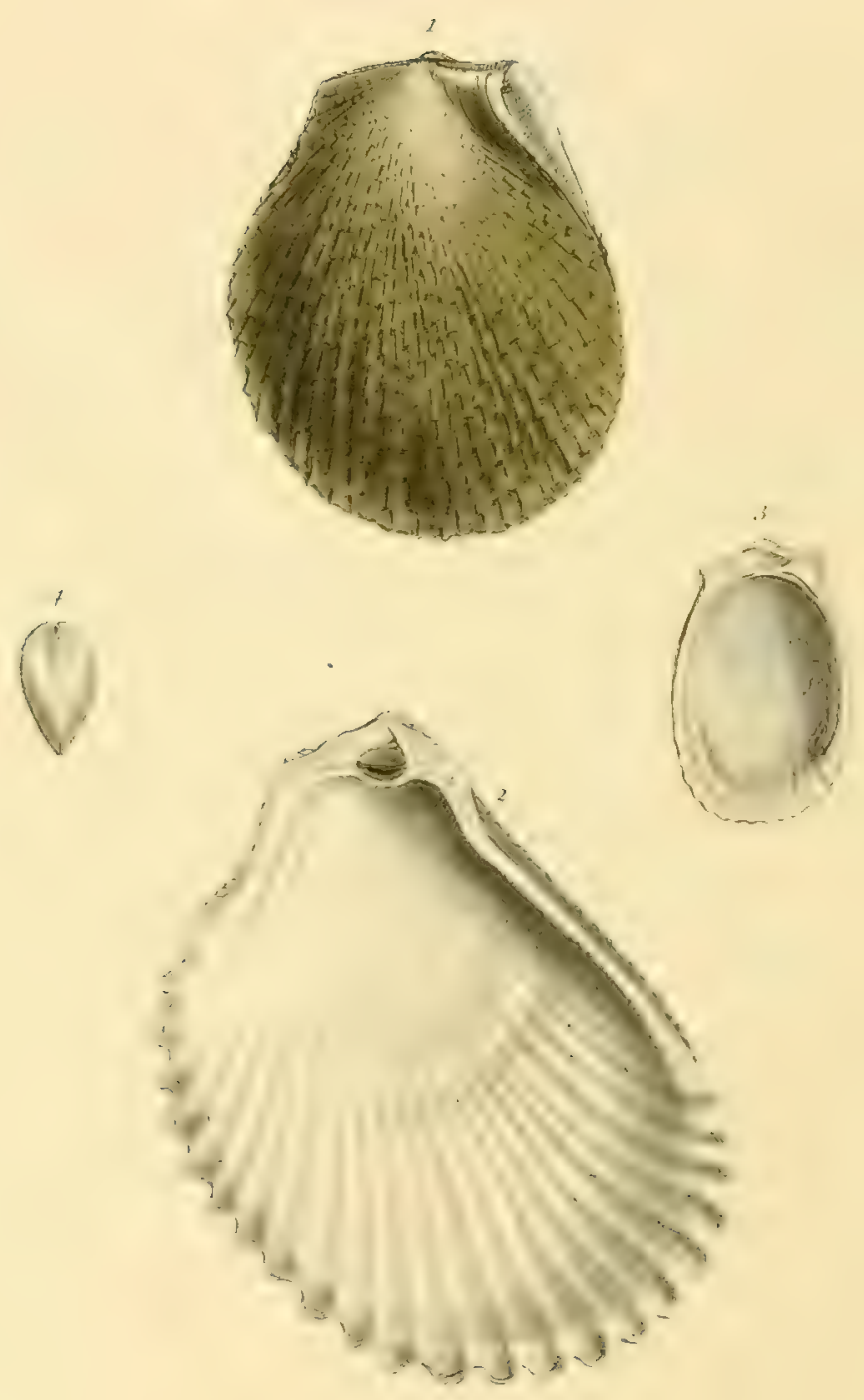

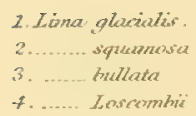


passage of a byssus, nor does it at all correspond with it in structure; but its affinity in every respect with that of Pecten appears remarkable.

It may be described as being longitudinal, nearly equivalve, auriculated and gaping on one side. The umbones are divergent, their internal facets being inclined outwards. The hinge is edentulate; but the margin is sometimes indistinctly crenulated on both sides. The ligament is partly external, inserted in a triangular pit in the centre of the oblique area. The muscular impression is inclined towards the side.

The shell of Lima is always white, covered with a brown horny epidermis. The valves are for the most part disposed in ribs, diverging in symmetrical order from the umbones to the margin, generally more or less imbricated externally.

\section{Examples.}

Pl. CXII. Fig. 1.

Lima glacialis, Lamarck, Anim. sans vert, new edit., vol. vii. p. 116. Enc. Méth., pl. 206. f. 2 and 3.

Ostrea glacialis, Gmelin.

Ostrea scabra? Born.

Pl. CXII. Fig. 2.

LIMA SQUAMOSA, Lamarck, Anim. sans vert., new edit,, vol. vii. p. 115. Enc. Méth., pl. 206. f. 4. De Blainville, Manuel de Malacologie, pl. $62 . \mathrm{f} .3$.

Ostrea lima, Linnæus.

PI. CXII. Fig. 3.

Lima bullata, Sowerby, Genera of Shells, No. 17. Chemnitz, vol. vii. t. 68 . f. 6496 .

Ostrea bullata? Born.

PI. CXII. Fig. 4.

Lima LoscombiI, Sowerby, Genera of Shells, No. 17.

Pecten Loscombii, Leach.

Pecten fragilis, Montague.

Pecten subauriculata, Montague. 
PECTEN, Bruguière.

Testa rotundata, rarò affixa, regularis, inæequivalvis, subæequilateralis ; valvis pectiniformibus, inæequaliter auriculatis, rarò paululùm hiantibus, costis vel sulcis ad margines ab umbonibus divergentibus. Cardo edentulus, linearis, ligamento tripartito, penitùs interno; partibus duabus lateralibus, elongatis, lineam cardinalem, rectam, sequentibus; tertiâ parte triangulari, crassâ, solidâ, in fossulâ centrali iusertî. Impressio muscularis magna, sublateralis. Animal bysso parvo interdum affixum.

We have already stated, in our observations on Lima, that the genus Pecten was proposed by Bruguiere for the purpose of distinguishing certain mollusks that had been previously arranged with the Ostrece. They are commonly known by the name of the Scullops, but their original and most popular title is that of the Combs: les Peignes of the French, Pectines of the Latins, and Krévec** of the Greeks. Their shells exhibit a most vivid array of colours, and the upper valve is usually more beautifully painted than the lower; the umbones approximate without the least indication of any disc or area, and in this respect they differ from all others of the family. The Pectines are very numerous, and may be subdivided into groups or sections, according to the inequality of the ears and of the valves: in some, both valves are flat; in others, both are convex; and in others, again, one valve is flat and the other convex (vide Pl.CXIII.). There appears to have been some difference amongst authors as to whether the animal of Pecten is provided with a byssus; Mr. Cuming informs us that he has only found certain species of Pectines with a byssus, and it

* The Kreis of Xenocrates and Galen is said to be the Pecten maximus of modern authors. 

Plate CXIII.
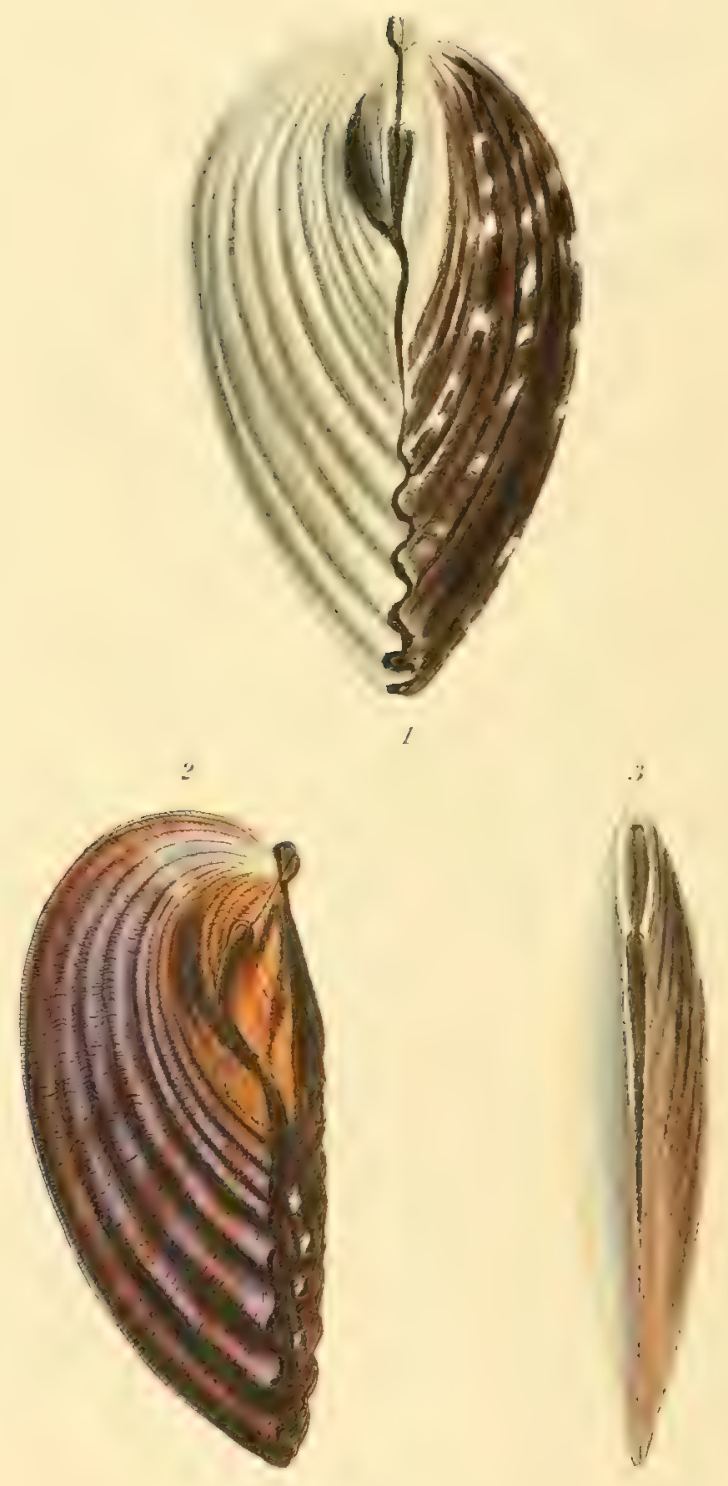

$$
\begin{aligned}
& \text { 1. Pecten turqidus. } \\
& \text { 2. fusches n. } \\
& \text { ?. Plemmotos. }
\end{aligned}
$$


was invariably very small. One species, the Pecten Pusio (PI. CIV. f. 6.), is remarkable on account of its shell being generally found attached to some marine body by the lower valve, thus forming an intermediate transition to the Plicatulc and Spondyli. Defrance proposes to establish a new genus for it, Hinnites, and we certainly think that this arrangement may be adopted with advantage.

The shell of Pecten may be described as being roundish, rarely attached, regular, inequivalve, and nearly equilateral; the valves are pectiniform, unequally auriculated, disposed in ribs or furrows radiating from the umbones to the margins, and sometimes, but very rarely, a little gaping. The hinge is edentulate, linear, and furnished with an internal ligament, which is tripartite; besides the thick, solid, triangular portion inserted in a small pit in the centre, there is a thin portion running parallel with the hinge margin on each side of it. The muscular impression is large and sublateral.

Examples.

Pl. CXIII. Fig. 1.

Pecten turgidus, Lamarck, Anim. sans vert., vol. vii. p. 135. Chemnitz, Conch., vol. vii. pl. 65. f. 621. $a, b$.

Ostrea turgida, Gmelin.

PI. CXIII. Fig. 2.

Pecten fuscus, Sowerby, Genera of Shells, No. 31.

Pl. CXIII. Fig. 3.

Pecten pleuronectes, Lamarck, Anim. sans vert, new edit, vol. vii. p. 132. Enc. Méth., pl. 208. f. 3. De Blainville, Manuel de Malacologie, pl. 60. f. 5 .

Ostrea pleuronectes, Linnæus.

Pl. CXIII. Fig. 4.

Pecten Pallium, Lamarck, Anim. sans vert., vol. vii. p. 140. Enc. Méth., pl. 210. f. 1. Chemnitz, Conch., vol. vii. pl. 64.f. 607 and 608. Ostrea pallium, Linnæus. 
160 CLASS I. TROPIOPODA. ORDER II. UNIMUSCULOSA.

\section{Pl. CXIV. Fig. 5.}

Pecten aurantiacus, Sowerby, Genera of Shells, No. 31.

Pecten unicolor? Lamarck.

Pl. CXIV. Fig. 6.

Pecten Pusio, Pennant, Zool. Brit., pl.61. f. 65. Donovan, Conch., pl. 34. Sowerby, Genera of Shells, No. 31.

Ostrea sinuosa, Linnæus.

- Ostrea miniata, Born.

Pecten sinuosus, Lamarck.

Hinnites sinuosus, Deshayes. Gray.

\section{Pl. CXIV.* Fig. 1 .}

Pecten histrionicus, Lamarck, Anim. sans vert., new edit, vol. vii. p. 141. Enc. Méth., pl. 213.f. 8.

Ostrea histrionica, Gmelin.

$$
\text { Pl. CXIV.* Fig. } 2 .
$$

Pecten mirricatust, Lamarck, Anim. sans vert, new edit, vol. vii. p. 141. Enc. Méth., pl. 214. f. 2.

Ostrea imbricata, Gmelin.

\section{Pl. CXIV.* Fig. 3.}

Pecten rastellumf, Lamarck, Anim. sans vert, new edit., vol. vii. p. 135. Delessert, Recueil de Coquilles, pl. 16. fig. 1, 2 and 3. $\boldsymbol{a}, \boldsymbol{b}$.

$$
\text { Pl. CXIV.* Fig. } 4 .
$$

Pecten pes-felis, Lamarcl, Anim. sans vert, new edit, vol. vii. p. 140 . Enc. Méth., pl. 211.f. 1.

Ostrea pes-felis, Linnzus.

Ostrea elongata, Born.

Pecten Bornii, Payrandeau.

\section{Pl. CXIV.* Fig. 5.}

Pecten exoticus, Chemnitz, Conch., vol. ii. p. 262. f. 2037, 2038. 
Plate CXIT.
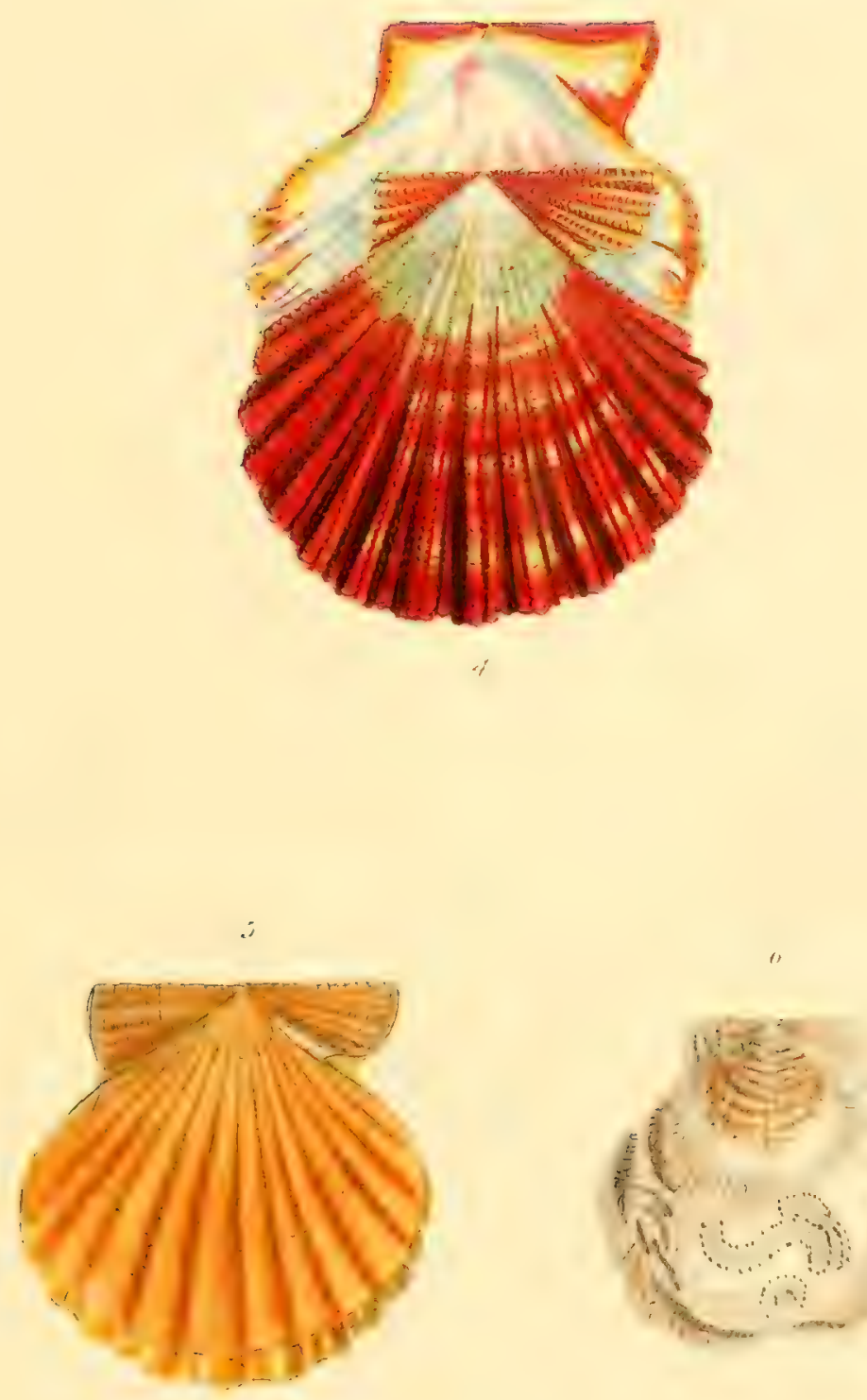

4. Piston Pallium

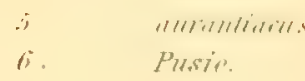



Plate CXIV.*

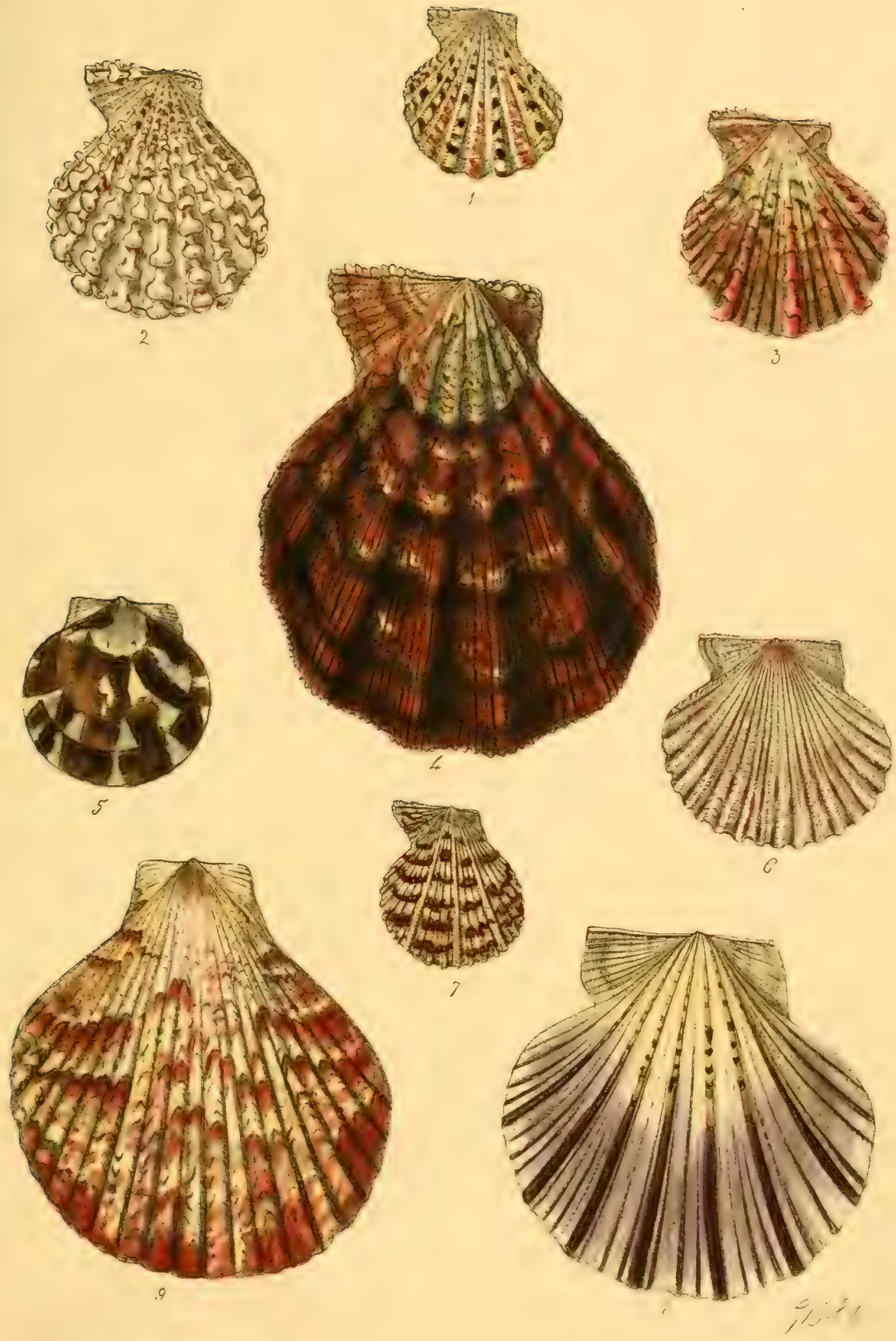



Pl. CXIV.* Fig. 6.

Pecten asper, Sowerby, Jun., Thesaurus Conchyliorum, Part 2.

Pl. CXIV.* Fig. 7.

Pecten sauciatus, Lamarck, Anim. sans vert., new edit., vol. vii. p. 142.

Chemnitz, Conch., vol. vii. pl. 69. f. H.

Ostrea sauciata, Gmelin.

Pl. CXIV.* Fig. 8.

Pecten superbus $\dagger$, Sowerby, Jun., Thesaurus Conchyliorum, Part 2.

Pl. CXIV.* Fig. 9.

Pecten bifrons, Lamarck, Anim. sans vert., new edit., vol. vii. p. 131.

Delessert, Recueil de Coquilles, pl. 15. f. 5. $a, b, c$.

PLICATULA, Lamarck.

Testa affixa, irregularis, inæequivalvis, inauriculata, basi attenuata; margine superiori rotundato, subplicato; umbonibus inæqualibus, areâ externâ nullâ. Cardo dentibus duobus, in utrâque valvâ validè intersertis, ligamento interno in fossulî intermediâ affixo. Impressio muscularis sublateralis, distinctè imbuta.

The Spondylus plicutus of Linnæus was selected by Lamarck as a type for the formation of the present genus, because its shell exhibits certain characters which he considered as intermediate between those of the genera Pecten and Spondylus. Like the former, it has no basal area or disc; like the latter, it becomes attached by the lower valve, and the hinge is furnished with teeth. It may be observed, however, that the Plicatulie are much more closely allied to the Spondyli; in fact, many

† The description of this beautiful species, from Mr. Cuming's collection, will shortly be published in the new Thesaurus Conchyliorum, by Mr. G. B. Sowerby, Jun., a work which is intended to consist of a series of Monographs illustrated on a more economical plan than has yet been attempted.

VOL. 1. 
authors of the present day are unwilling to admit of any distinction. It is certainly difficult to trace a distinct umbonal area in some Spondyli, but still this peculiarity of growth is remarkable in most of the species; there is moreover a certain character about the Plicatulæ by which they may be readily distinguished.

The shell of Plicatula may be described as being attached, irregular, inequivalve, attenuated towards the base, but not auriculated; the upper margin is round and somewhat plicated; the umbones are unequal, and do not form any external area. The hinge consists of two teeth in each valve strongly interlocking with each other; and the ligament is internal, inserted in an intermediate pit. The muscular impression inclines towards the side, and is very strongly marked.

\section{Examples.}

Pl. CXV. Fig. 1 and 2.

Plicatula gibbosa, Lamarck, Syst. Ann., p. 132. Chemnitz, Conch., vol. vii. pl. 47. f. 479 and 480.

Spondylus plicatus, Linnæus. Deshayes.

Plicatula ramosa, Lamarck (Anim. sans vert.).

Pl. CXV. Fig. 3. (fossil.)

Plicatula spinosa, Sowerby, Mineral Conch., pl. 245. Genera of Shells,

No. 3. Enc. Méth., pl. 175. f. 1 to 4.

Placuna pectinoides, Lamarck.

Plicatula pectinoides, Deshayes.

Harpax (pectinoides ?), Parkinson. Gray?

Harpax Parkinsonii? De Blainville.

SPONDYLUS, Linnæus.

Testa affixa, inæequivalvis, subirregularis, plus minusve auriculata, extùs vel rigida vel spinosa; umbonibus inæqualibus, valva inferioris areâ 
Plate CXV.
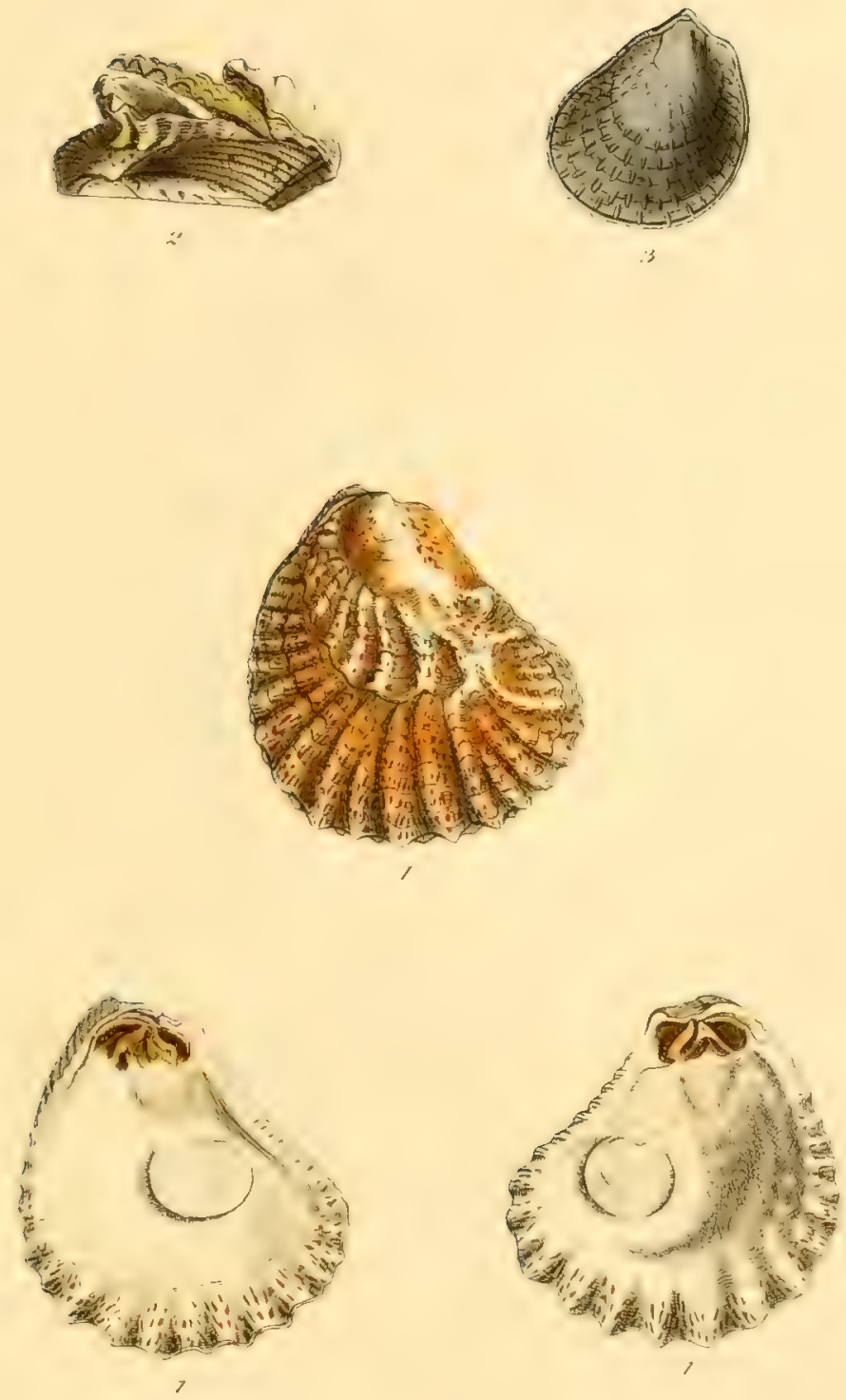

Id.27irntwler gibluns 

cardinali externâ separatis. Area plana, trigona, xtate productior, sulco ligamentifero interdum obtecto, partita. Cardo dentibus duobus solidis, reflexis, in utrâque valvî, validè intersertis, ligamentum in cavitatem inter se recipientibus. Impressio muscularis sublateralis.

The Spondylus or Thorny Oyster appears to have been well known to the ancients; both Aristotle and Galen having been struck by the beauty

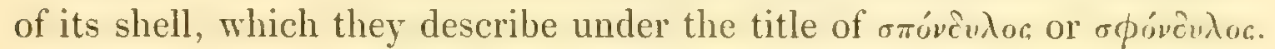
The Spondyli are remarkably characteristic; indeed, the present genus remains nearly as entire as in the time of Linnæus : they differ materially from the Pectines, and might perhaps with more propriety be associated with the Plicatulce in a separate family. The shell of Spondylus is thicker and of more irregular growth than that of Pecten; it is always attached by one or both valves, and there is a marked change in the hinge, both in being provided with teeth and in forming a solid umbonal area. From the ponderous structure of some of them the animal appears to have a most abundant supply of calcareous matter ; the peculiarity of growth noted in our observations on I'ulsella is here very conspicuous, for as the shell advances in growth we find the valves to be composed of several distinct plates, deposited in progressive order one upon the other. In one species, the Spondylus varius, this laminar structure is very remarkable; the plates are so irregularly secreted as to admit the water between them, so that when the last plate is deposited it is completely sealed up. In many individuals of this species the water may be seen through the transparency of the shell: hence they are commonly called the Wrater Spondyli.

The shell of Spondylus may be described as being attached, inequivalve, somewhat irregular, and more or less auriculated. The outer surface is rarely smooth; in fact, nothing can exceed in beauty the varieties of external development whether of spines or foliations; their colours also are exceedingly bright and various. The umbones are unequal, and separated from each other by a flat triangular disc on the lower valve. The disc is always perfectly smooth; it increases with the growth of the 
shell, and a longitudinal groove is formed down the centre by the advance of the ligamentary cavity. This groove is always partially filled with the decayed remains of the original ligament; in some species it is exposed (vide Pl. CXVII. f. 3.); in others it is thinly covered over (vide PI. CXVIII. f. 6.). The hinge consists of two solid bent teeth in each valve, strongly interlocking with each other, and the cavity containing the ligament comes exactly between them. The ligament is very strong and solid, and by the aid of this, with the interlocking teeth, the valves are very firmly united; Sowerby asserts that there is also a slender portion of ligament running along the binge margin. The muscular impression is sublateral.

There has always been considerable difficulty in determining the species of this much admired genus; nearly all the varieties, indeed, that were known to Linneus and his contemporaries were referred to the Spondylus gedaropus. Their shell becomes very variably modified, in fact, often distorted, by their peculiar situations of growth, and the spines or foliations are thrown out in great abundance to afford facilities for their attachment. The valves, like those of the Pectines, are sometimes alike, as in the Spondylus regius; sometimes different, as in the Spondylus Americamus; but in these latter the upper valve is usually the richer both in colour and ornamental development.

\section{Examples.}

Pl. CXVI. Fig. 1.

Spondylus Americanus, Lamarck, Anim. sans vert., new edit., vol. vii. p. 185. Enc. Méth., pl. 195. f. l and 2. Chemnitz, Conch., vol. vii. pl. 45. f. 465.

Spondylus gredaropus (var. 0.), Gmelin.

PI. CXVI. Fig. 2.

Spondylus princeps, Broderip, Proceedings Zool. Soc., 1833, p. 4.

Pl. CXVII. Fig. 3.

Spondylus gadaropus, Linnæus, Syst. Nat., p. 1136. Enc. Méth., pl. 190. f. l. $a, b$. Chemnitz, Conch., vol vii. pl. 44. f. 459. 
Plate CXVI.

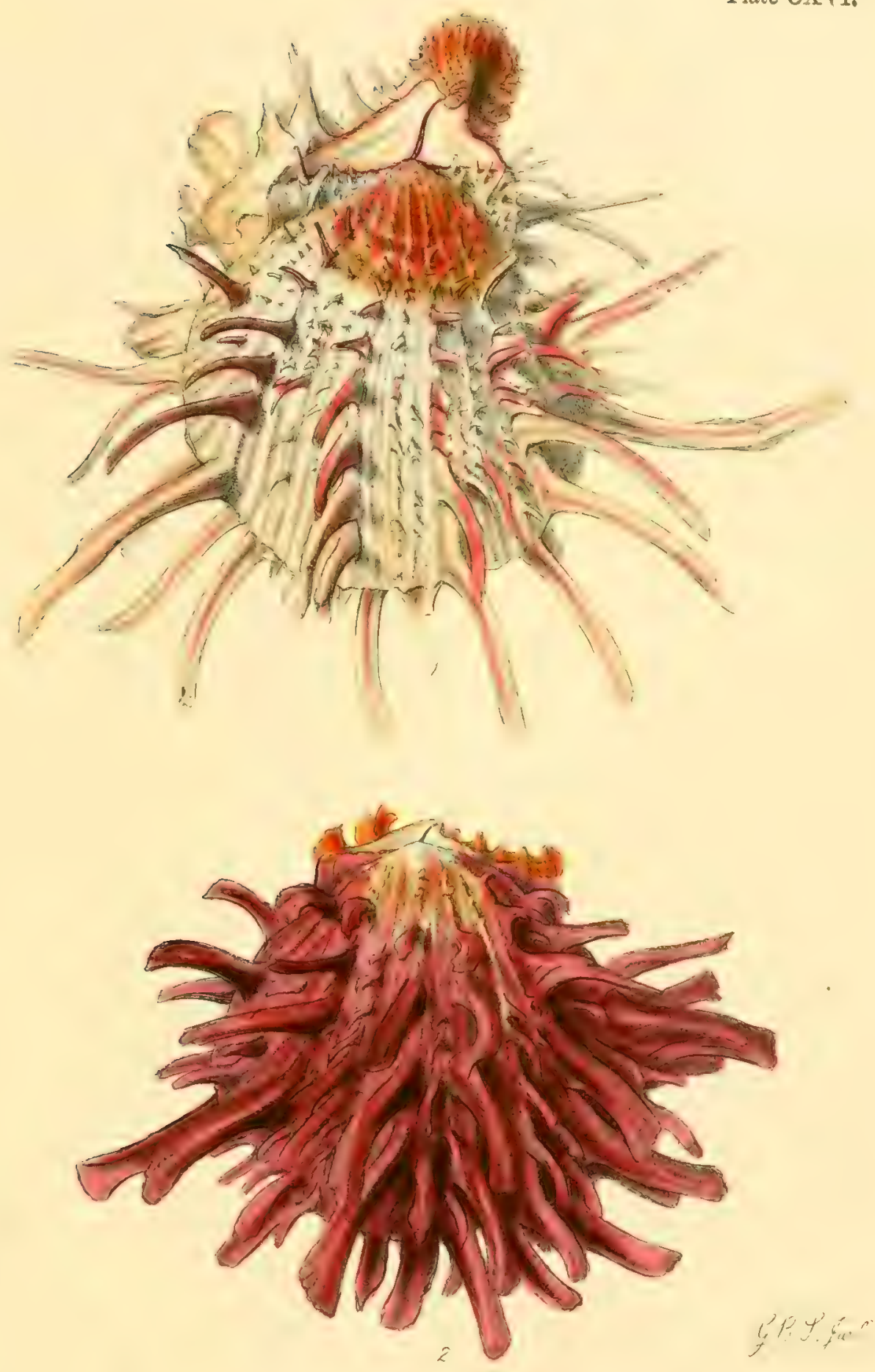



Mate CITII.

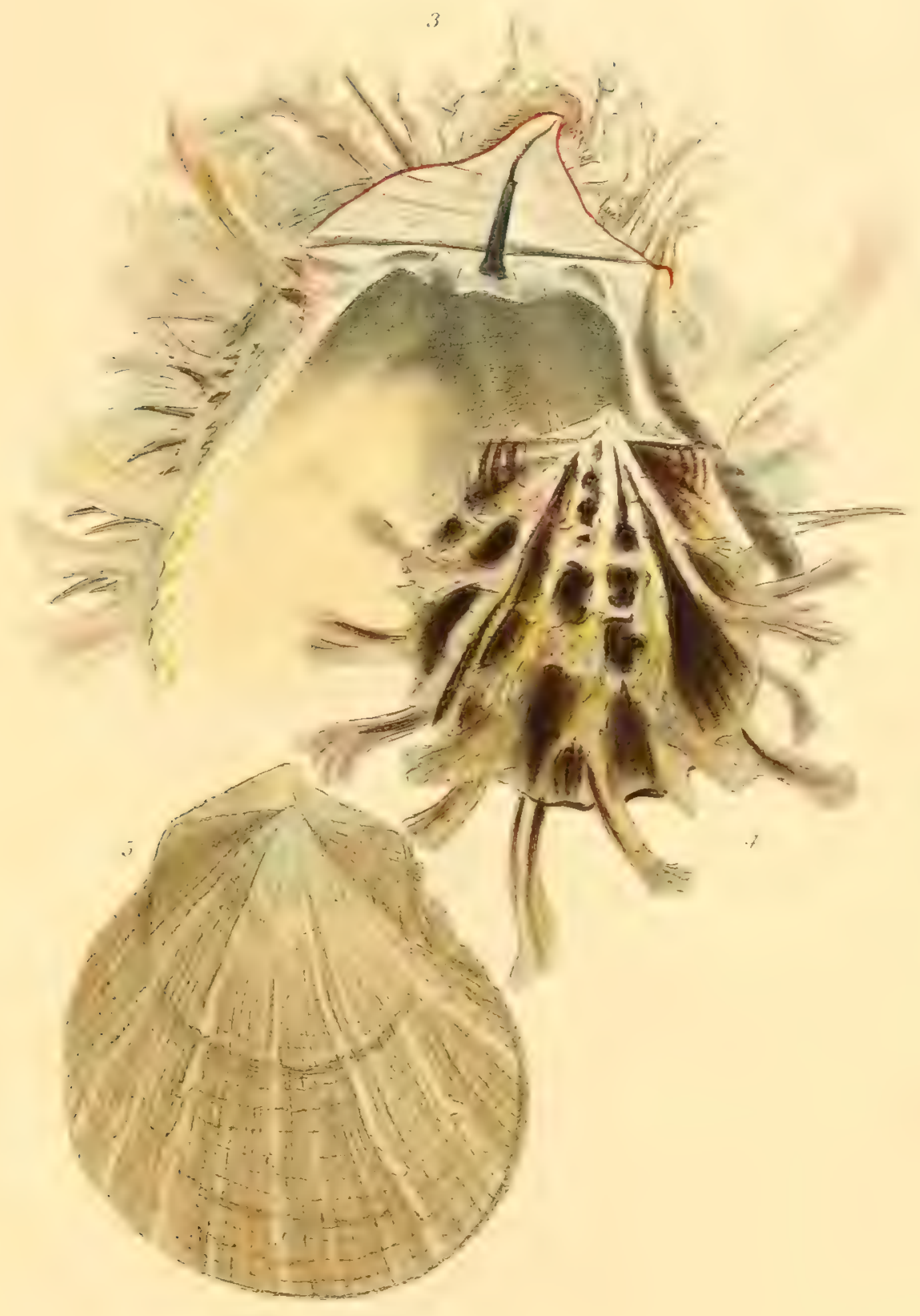

3..Spond? lus goedaropus.

4............... ducalis

5 ................. podopsideres 


Plate CXVIII.

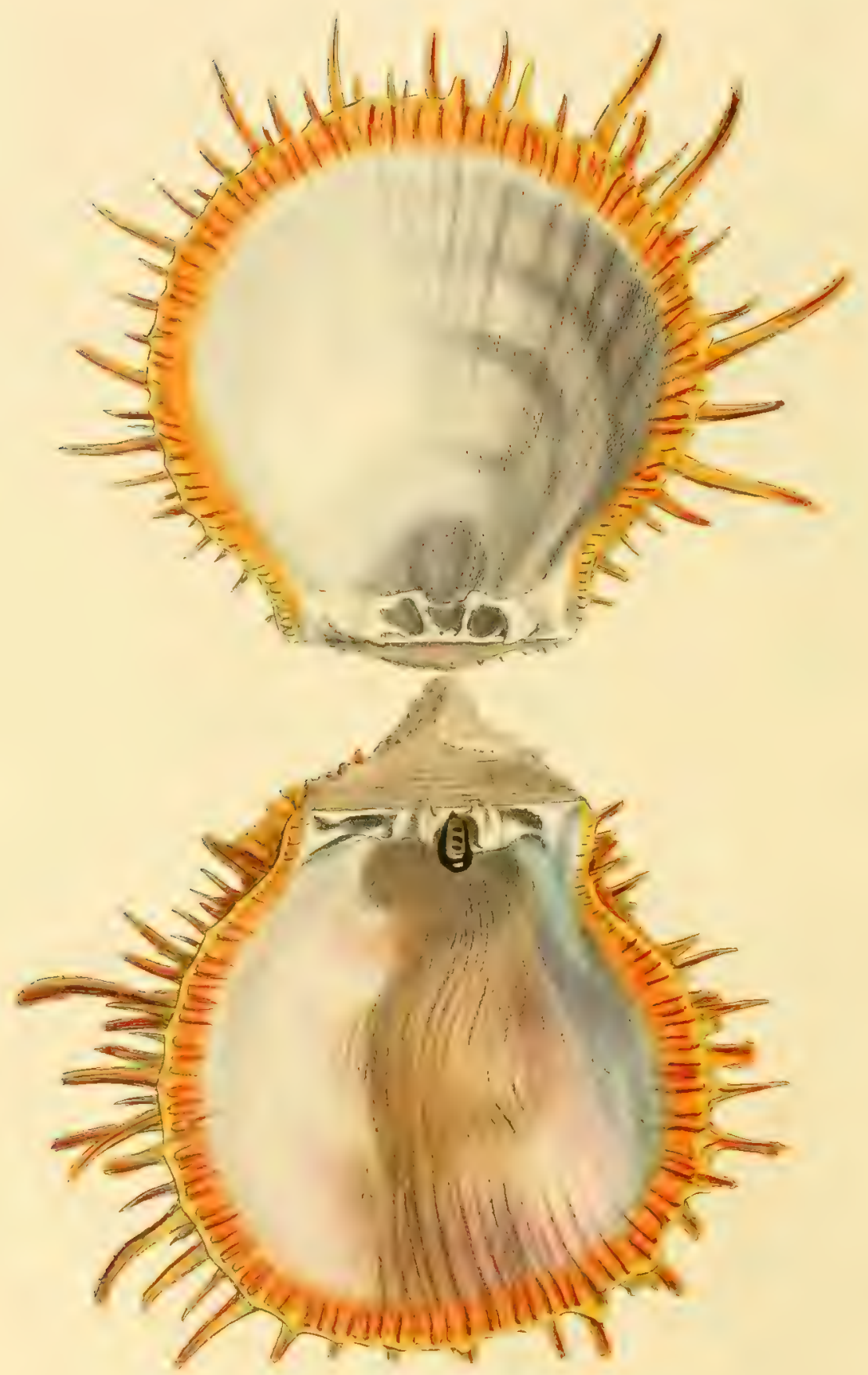

Spondrlus marantius. 



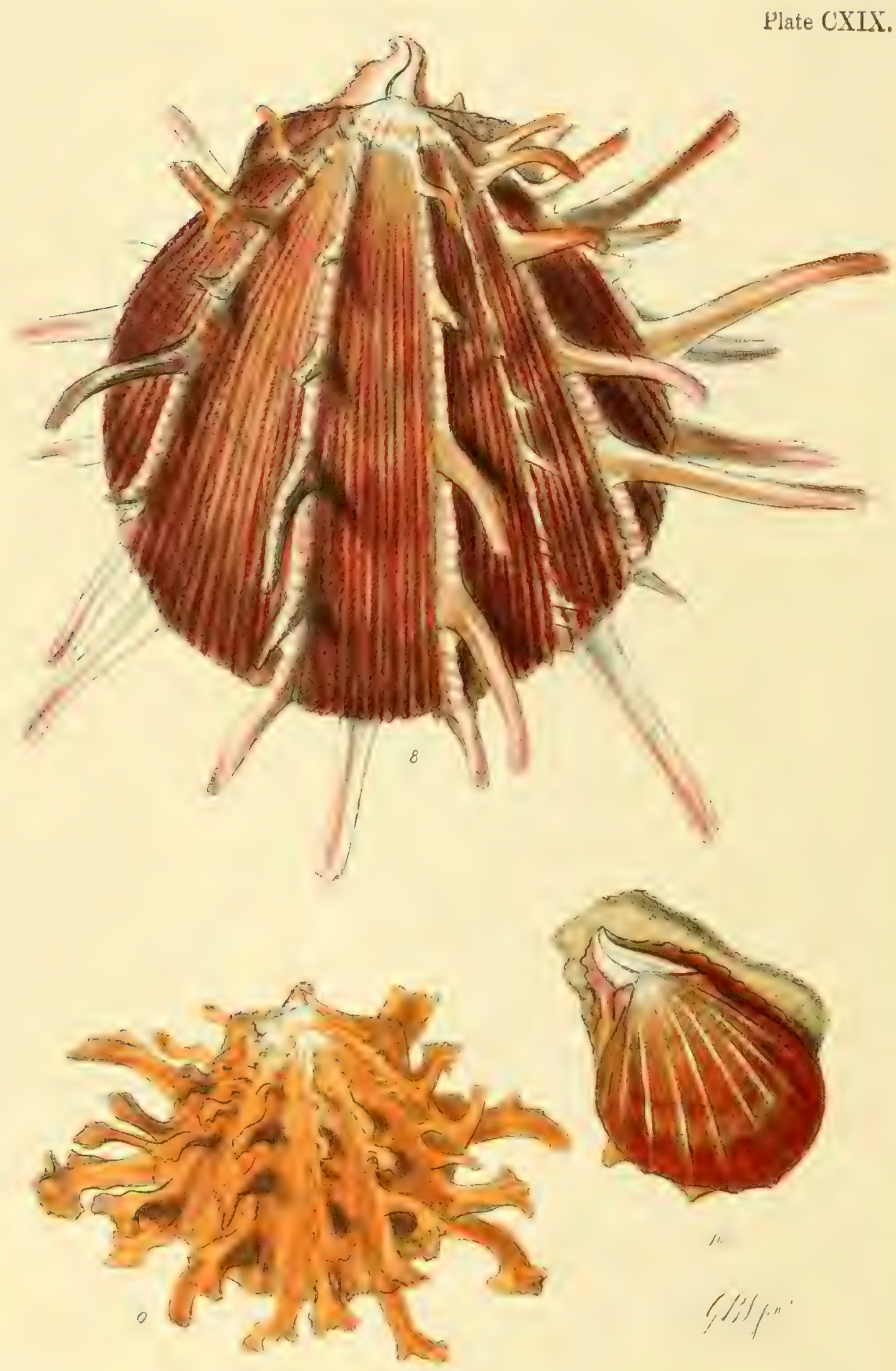


P1. CXVII. Fig. 4.

Spondylus ducalis, Chemnitz, Conch., vol. vii. pl. 47 . f. 477 and 478 .

Enc. Méth. pl. 193. f. 2, $a, b$.

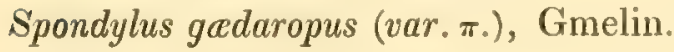

PI. CXVII. Fig. 5. (fossil.)

Spondylus podopsideus, Lamarck, Anim. sans vert., new edit., vol. vii. p. 192. Sowerby, Genera of Shells, No. 9.

Pl. CXVIII. Fig. 6 and 7.

Spondylus aurantius, Lamarck, Anim. sans vert., new edit, vol. vii. p. 190. Enc. Méth., pl. 191. f. 3.

\section{PI. CXIX. Fig. 8.}

Spondylus regius, Linnæus, Syst. Nat., p. 1136. Enc. Méth., pl. 193. f. 1. Chemnitz, Conch., vol. vii. pl. 46. f. 47 J.

Pl. CXIX. Fig. 9.

Spondylus spathuliferus (var. aurantia), Lamarck, Anim. sans vert., vol. vii. p. 189. Enc. Méth., pl.191. f. 4, 6 and 7 *.

PI. CXIX. Fig. 10.

Spondylus nudus, Chemnitz, Conch., vol. xi. p. 235. pl. 203. f. 1989 and 1990 .

* The figures referred to in the 'Encyclopédie Méthodique' are evidently drawn from bad specimens; they do not, indeed, exhibit the spathulate termination of the spines described by Lamarck as characteristic of this species, and which are so well developed in the specimen belonging to the Rev. Mr. Stainforth, from which our drawing is taken.

+ We are much indebted to Mr. Sowerby for pointing out to us the description and figure of this species in Chemnitz; it appears to have escaped the notice of Lamarck and subsequent authors. 


\section{Family 5. OSTRACEA.}

Testa affixa, irregularis, foliata vel laminaris, rarò auriculata, tenuis, interdum translucida, valvâ unî̀ majore. Ligamentum internum aut semi-internum.

The Ostracea are somewhat allied to the Pectinacea, but differ in many essential peculiarities; and the passing out of a bony tendon through an orifice in the shell in two of the genera is quite a new and particular feature. Their shells also differ both in structure and composition; the valves are not radiated from the umbones like those of the Pectinacen, nor are they so solid and calcareous, approaching rather, indeed, in composition to the fibro-laminar shells of the Aviculacea. Cuvier's family of Les Ostracées was one of considerable extent, including both the families of the Aviculacea and the Pectinacea; but Les Ostracées of Lamarck consist of five genera merely, three only of which are retained. We have already noted in our observations on Vulsella (vide p. 149) the reason of that genus being removed; and the genus Grypheea, which Lamarck also included in this family, is united to Ostrea (vide p. 167), the incurvature of the umbones, by which its shell is distinguished, being nothing more than an inconstant variety of growth. We have, however, the pleasure of introducing the new genus Placunanomia, which forms a singular and most important link in the distribution of this family.

The shell of the Ostracea may be described as being attached, irregular, either foliated or laminar, and rarely auriculated; it is moreover thin, sometimes quite translucid, and one valve is always larger than the other. The ligament is either internal or semi-internal.

The Ostracea are divided into four genera, as follows:

$\begin{array}{ll}\text { Ostrea. } & \text { Placunanomia. } \\ \text { Placuna. } & \text { Anomia. }\end{array}$




\section{OSTREA, Linnæus.}

Testa affixa, inæquivalvis, irregularis, umbonibus subdivaricatis, inæqualissimis, incremento areæ plus minusve distantibus; valvis fibrolaminaribus; inferiore majore, concavâ; superiore minore planiusculâ. Cardo edentulus, ligamento semi-interno areâ valvarum superposito. Impressio muscularis subcentralis.

It may be noticed in the course of our observations on the preceding family, that the genus Ostrea of Linnæus has been variously dismembered by Bruguière and succeeding writers. Originally it included some of the byssiferous Mollusca, such as the Mallei, the Pectines and others, whose shells differ not only in their mode of attachment, but in being of an entirely different structure and composition. It is, however, somewhat curious to find that there are two or three species which, although strictly belonging to the genus Ostrea in its present dismembered form, were not referred to it by Linnæus; Lamarck, who has not failed to notice this apparent error of discrimination in the great author of the 'Systema Naturne, mentions his Mytili hyotis, frons and crista-galli, as examples of those which should certainly have been placed with the Ostrea. The shells of the Ostrex exhibit considerable varieties of growth; in fact, there is no genus of mollusks in which we find such a multiplicity of distorted forms. As the animal increases in age it gradually recedes from the base of its shell, and the dorsal area which is thus formed (vide Pl. CXX. fig. 2), as in the shell of Spondylus and others, is sometimes so considerably extended as to become modified or distorted to almost any situation in which it happens to be confined. These inconstant modifications of growth have been seized upon, as is too frequently the case, for the formation of new genera. The genus Gryphca, for example, was proposed by Lamarck for the purpose of distinguishing those 
varieties of Ostrex in which the umbones have been involutely pressed over; and those in which the umbones are distorted to the left have been set apart by Say under the new generic title of Exogyra. The first of these genera has been the most esteemed by conchologists, because the distinction is tolerably well marked, and particularly refers to a large number of fossil species; we conceive, however, that the legitimate rank of this division will be fully maintained by regarding it merely as a section of the primitive genus (gryphoid Ostrece, e. g.). These capricious alterations are highly injurious to the true principles of classification; instead of simplifying the arrangement, they tend to confuse it; and we cannot but deprecate the innovations of those authors, who attempt to give a place in the nomenclature to every little variation in the inscrutable operations of Nature.

The shell of Ostrea may be described as being attached, inequivalve, and irregular; the umbones are very unequal, somewhat divaricating, and receding from each other as the area between them becomes enlarged by the increase of the shell; the valves are fibro-laminar, and sometimes foliated; the lower valve, which is always the larger, is concave, and the upper or smaller valve is generally flattish. The hinge is destitute of teeth, and the ligament is either internal or semi-internal, attached to the umbonal area. The muscular impression is situated near the centre, and the mark of a minute accessory cartilage has been noticed beneath the hinge, analogous to that of the Pinne.

We refer our readers to the various Encyclopredias for accounts of the manner in which immense beds of the Ostrea edulis are cultivated for the purposes of food. This species has long been a common article of luxury throughout the whole of Europe; it was in general consumption in the time of the ancient Romans, and the "or petov of the Greeks is frequently mentioned by the old writers*.

* An interesting account of the oyster-beds of America has been very recently published by Dr. Augustus Gould of Boston, in his 'Report on the Invertebrate Animals of Massachusetts' (page 358). It does not come within the object of the present work to enlarge upon the habits of the Mollusca, or we should certainly have given some extracts from this elaborate report. 

Plate CXX.

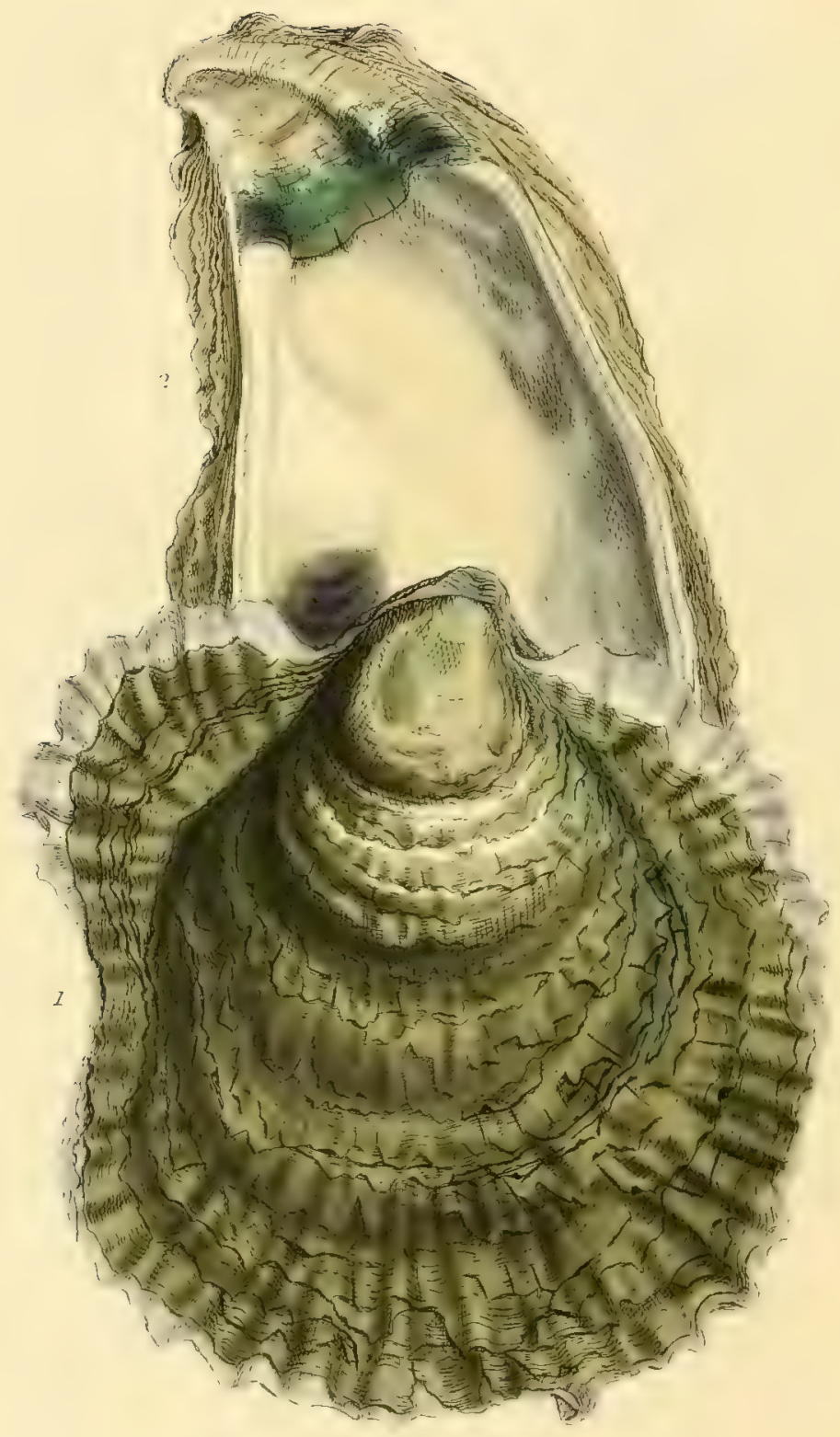

1. Ostren edulis.

Irominica 

Plate CXXI.

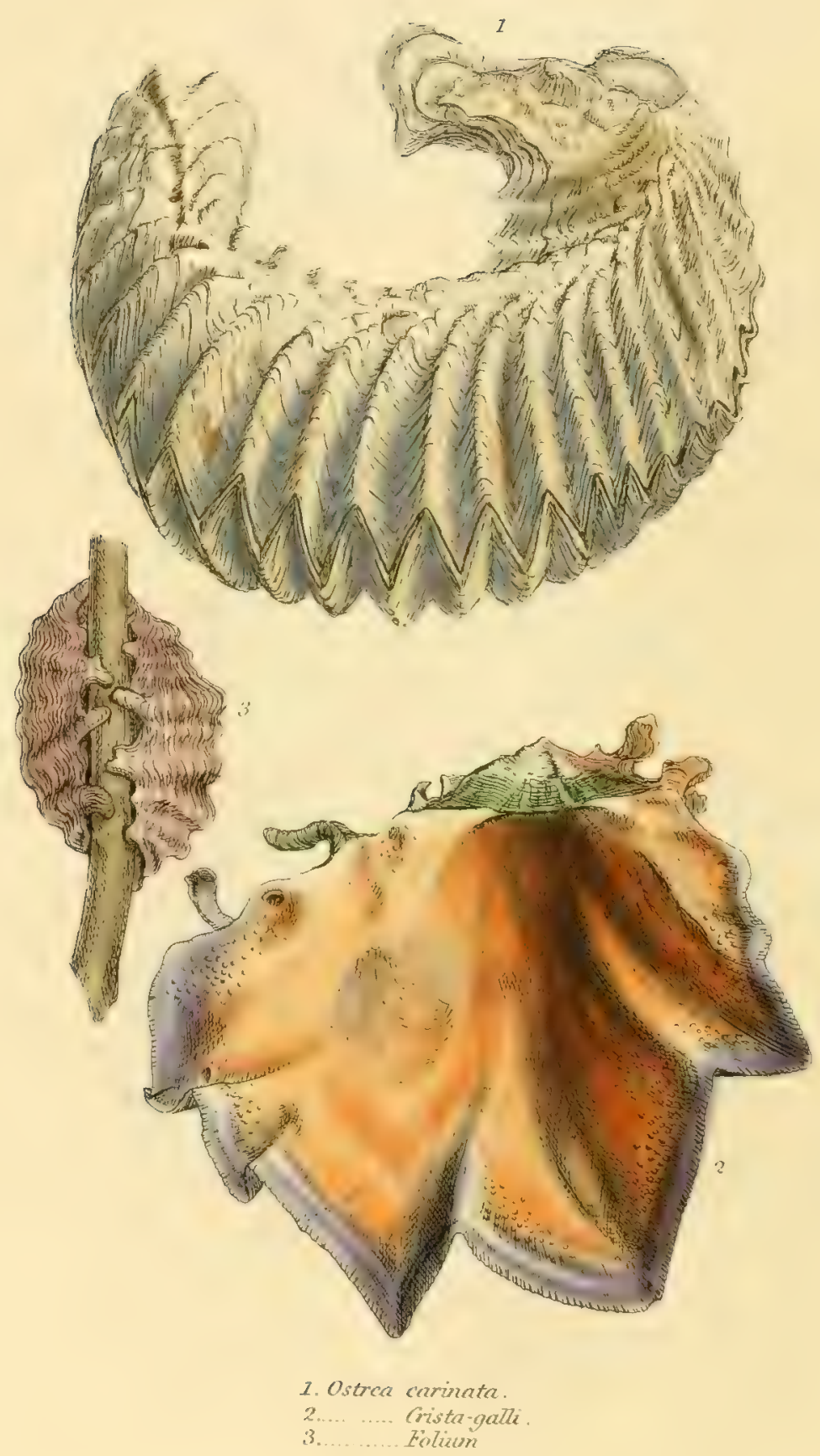




\section{Examples. \\ Pl. CXX. Fig. 1.}

Ostrea edulis, Linnæus, Syst. Nat., p. 1148. Lamarck, Anim. sans vert., new edit., vol. vii. p. 217. Enc. Méth., pl. 184. f. 7 and 8.

PI. CXX. Fig. 2.

Ostrea Virginica, Gmelin, p. 3336. Lamarck, Anim. sans vert., new edit., vol. vii. p. 226. Enc. Méth., pl. 179. f. 1 and 5.

Ostrea rostrata, Chemnitz.

Pl. CXXI. Fig. 1. (fossil.)

Ostrea carinata, Lamarck, Anim. sans vert., new edit., vol. vii. p. 240.

Enc. Méth., pl. 187.f. 3 and 5. Sowerby, Genera of Shells, No. 6.

Pl. CXXI. Fig. 2.

Ostrea crista-galli, Chemnitz, Conch., vol. viii. pl. 75. f. 683 and 684. Lamarck, Anim. sans vert., new edit., vol. vii. p. 234. Enc. Méth., pl. 186. f. 3 and 5 .

Mytilus crista-galli, Linnæus.

PI. CXXI. Fig. 3.

Ostrea foliux, Linneus, Syst. Nat,, p. 1148. Lamarck, Anim. sans vert., new edit., vol. vii. p. 232. Enc. Méth., pl. 184. f. 10 and 14.

\section{PLACUNA, Bruguière.}

Testa libera, fibro-laminaris, tenuissima, complanata, translucida, orbicularis, subrquivalvis. Cardo costis duabus angustis, longitudine inæequalibus, ad basem convergentibus, in valvâ alterâ; cicatrulis duabus in alterì. Ligamentum per marginem externum costarum VOL I. 
cardinalium affixum, utrinque partim extensum. Impressio muscularis centralis.

The genus Placuna, originally confounded by Linnæus and his followers with Anomia, was introduced by Bruguière. Its shell, though easily recognised by the thimness and flatness of the valves, is particularly distinguished by the peculiar construction of the hinge. It consists of two distinct ribs or ridges, on one valve only, diverging upwards; and to the outer edge of these is attached the ligament. The valves are of the same thin fibro-laminar structure as those of the Ostrece; and although the shell of that genus does not exhibit any indication of this new cardinal development, it is very characteristic in the genus Placunanomia, which follows. We cannot agree with Deshayes in considering the cardinal ridges of the Placunx as a modification of the bony organ of adhesion in the Anomia, because these two parts are destined to perform separate offices, and are both distinctly exhibited in the new and remarkable genus just alluded to.

The shell of Placuna may be described as being free, fibro-laminar, very thin, smooth, transparent, orbicular, and nearly equivalve. The hinge consists of two narrow ribs, unequal in length, converging at the base in one valve; whilst in the other are merely the corresponding marks. The ligament runs along the outer edge of these cardinal ridges, extending partially on both sides of the umbones.

The valves of the following species are so thin and transparent, that they are used by the Chinese for the purpose of glazing windows, lanterns, \&c., in the same way as horn is sometimes used in this country.

\section{Example.}

PI. CXXII. Fig. 1 and 2.

Placuna placenta, Lamarck, Anim. sans vert., netr edit., vol. vii. p. 270. Enc. Méth. pl. 173. f. 1 and 2. De Blainville, Manuel de Malacologie, pl. 60. f. 3.

Anomia placenta, Linnæus. 
Plate CXXII.

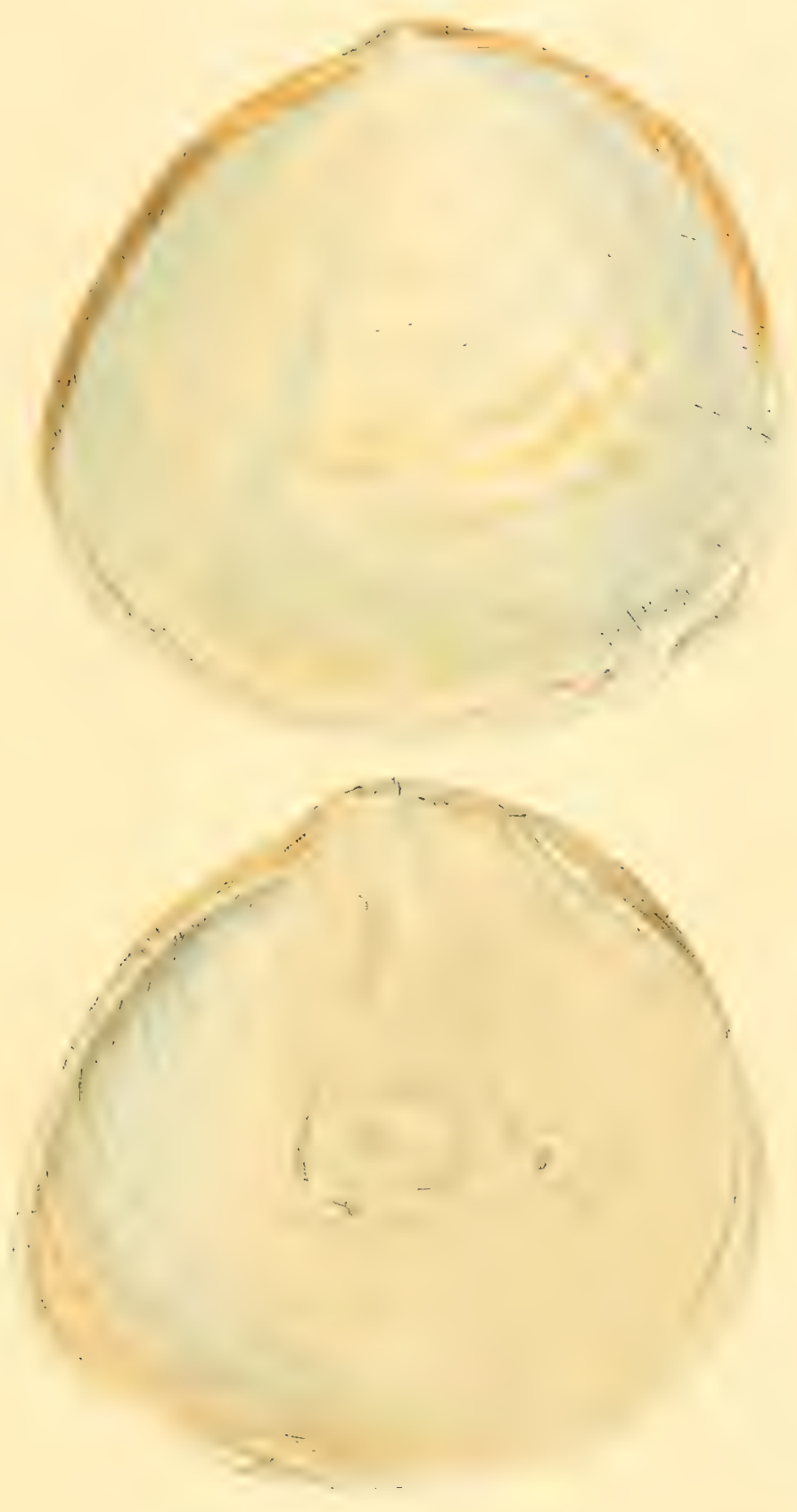

Ilervenel I'lesente 

PLACUNANOMIA, Broderip.

Testa irregularis, subæquivalvis, complanata, marginem versus plicata, nternè vitrea. Cardo costis duabus angustis, longitudine inæequalibus, ad basem convergentibus in valvâ alterâ; sulcis duobus ligamentiferis in alterâ. Valva inferior propè ad cardinem fissurata; fissurâ tendine adhresionis subosseo, inter testre laminas inserto, inpletâ. Impressio musculi in utrâque valvâ subcentralis; impressione tendinis superadditâ in valvầ superiore. Animal organo subossen affixum.

There are few instances on record in the natural history of the Mollusca, where an apparent gap in the system has been more accurately filled up than by the genus under consideration; uniting, by the semblance of its characters, two particular genera which had not been previously associated without considerable doubt. We are indebted to the molluscomania of that indefatigable traveller Mr. Cuming, who may be said to have spent half his life in diving and dredging, for the discovery of this remarkable animal. It was found by him attached to dead bivalve shells and corals, at the depth of eleven fathoms, in the Gulf of Dulce, province of Costa Rica, Central America; and it has been recently described for the first time by Broderip, under the appropriate title of Placunanomia. Its shell, as the name denotes, is indeed exactly intermediate between those of Placuna and Anomia: like the former, the hinge consists of two divaricate ribs, bearing the ligament; and, like the latter, there is an opening in the lower valve for the passage of a bony tendon by which the animal attaches itself. 'This subosseous organ, however, is rather a singular modification of that in the Anomice: instead of directly perforating the lower valve, it is first introduced, like a flat plate, between the laminx of which the valve is composed, and then passes out, for the purpose of $\mathrm{z} 2$ 
attaching itself, through a narrow longitudinal fissure; it is moreover confined within the aperture; not free, as in Anomia. As the animal advances in growth this fissure is obliquely prolonged; and the tendon of adhesion, which is of a more bony character than that of Anomia, becomes ossified in order to strengthen its power of attachment as the shell enlarges. Thus the Placunanomix are important as establishing a complete affinity between two genera in which little had apparently existed.

The shell of Placunanomia may be described as being irregular, nearly equivalve, smooth, plaited round the edge, and somewhat glassy inside. The hinge consists of two narrow ribs, unequal in length, converging at the base, in one valve; and in the other are two corresponding grooves for the reception of the ligament which runs along the edge of the cardinal ribs. The lower valve is longitudinally perforated near the hinge, and the opening or fissure is entirely filled up by the ossification of the tendon passing through it, a portion of which is also inserted between the lamine of the shell. The impression of the chief adductor muscle is nearly central in both valves, and there is also a mark in the upper valve, which shows the internal attachment of the other extremity of the tendon or organ of adhesion.

Since the under-mentioned species has been described, one or two others have been observed, though somewhat less characteristic.

\section{Example.}

Pl. CXXIII. Fig. 1 and 2.

Placunanomia Cumingin, Broderip, Proccedings Zool. Soc, 18:32, p. 28. Suwerby, Genera of Shells, No. 38.

ANOMIA, Linnæus.

'Testa inxequivalvis, irregularis, aftixa; valvâ inferiore planiusculì propè ad cardinem orbiculatim perforatâ, aperturâ parietibus reflexis ten- 
Platc CXIt1).
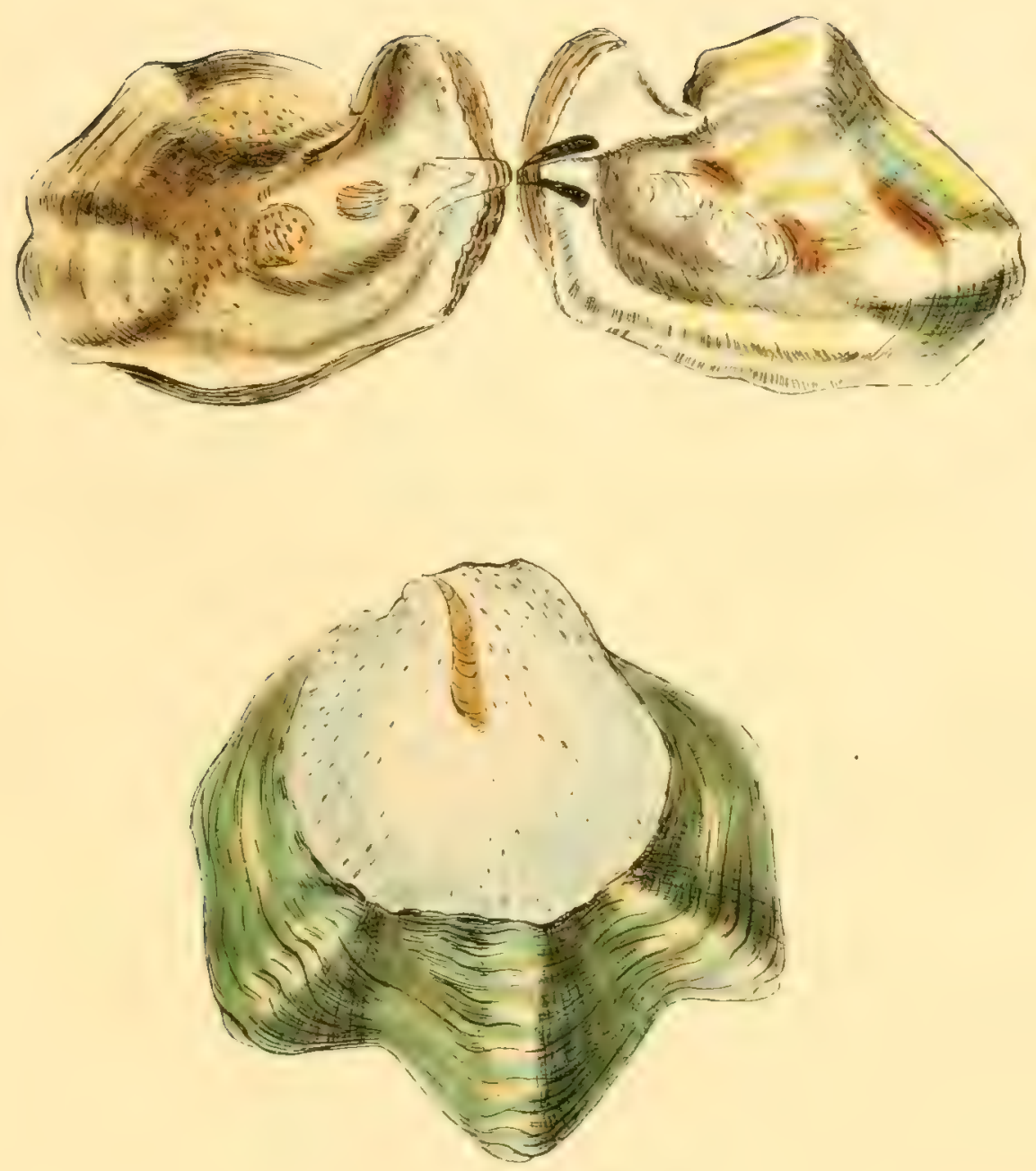

dine adhesionis subcalcareà libere impleti; valvit superiore concavi, impressione musculi cartilaginibusque accessoriis duabus imbuti. Ligamentum internum sub umbonibus positum.

This genus originally included not only the Anomixe of modern authors, but also many of those mollusks which, on account of their peculiar system of organization, have been considered as constituting two distinct classes, Brachiopoda and Pteropoda. The Anomix, the Terebratule, and the Hyalcec nere associated together in one and the same genus by Linnaus from a fancied resemblance in their shells, without reference to the structure and habits of their animal inhabitants; and when their anatomy, therefore, attracted the notice of scientific men, the fallacy of this arrangement became manifest. It would be both frirolous and unnecessary to notice the grounds upon which these important changes in the classification have been established, as, on reference to the descriptive characters of these classes, they may be at once detected. The Anomia do, nevertheless, exhibit a certain indistinct transition to the Terebratule, inasmuch as they both live attached to rocks, shells, and other marine debris by the aid of a muscular tendon passing through a distinct orifice in the shell: here, howerer, the resemblance ceases. Through the fibres of this tendon of adhesion which is exserted by the Anomix, there is secreted, after a time, on the surface to which it is affixed, a series of thin subcalcareous plates; and when these plates become amalgamated and hardened, they form what has been called the stopper. This peculiarity of habit is not found in the Terebratule; the soft parts are moreorer altered in their position within the shell, besicles differing in many other essential particulars. By the interposition of the genus Placunanomia, the Anomix are closely allied to the Placunce; their shells are of the same fibro-laminal composition as those of the rest of the Ostracea, and are often much distorted in growth. As they assume the shape of any substance they happen to be in contact with, it is impossible to attach any importance, in drawing up a specific description. to the regularity or irregularity of the valves. It, for example, the Anomix become attached to at flat surface, their shells are well and regularly. 
formed; if, on the contrary, they are found upon the radiated valve of a Pecten, they are ribbed accordingly; and if confined between the spines of an Echinus, they become compressed. This may probably arise from the fact of the Anomiæ not being provided with any foot or organ of locomotion; they are indeed said to live and die in the same place where they are deposited in ovo.

The shell of Anomia may be described as being inequivalve, irregular, and fixed. The lower valve, which is generally rather flat, is orbicularly perforated near the hinge; and the aperture, with the edges turned back, is filled up by the calcareous organ of adhesion; it is, however, still free within the aperture, and differs in this respect from that of Placununomia. The upper valve is generally concare, and exhibits the impressions of two accessory cartilages in addition to that of the chief muscle. 'The ligament is internal, situated beneath the umbones.

The species which we have selected as an example is common to our own coast.

\section{Example.}

Pl. CXXIV. Fig. 1, 2 and 3.

Anomia ephippica, Limneus, Syst. Nat., p. 1150. Lamarck, Anim. sans vert., new edit., vol. vii. p. 273. Enc. Méth., pl. 170. f. 6 and 7.

\section{Class II. BRACHIOPODA.}

Animal ovatum vel oblongum in testi bivalvi perpetuò affixum; ore mediano; capite oculisque nullis; brachiis ciliatis duobus ad spiram pertinentibus; musculis plurimis. Viscera abdominalia parvá, lobis pallii utrinque protecta. Branchiæ vasculares, symmetricæ, pallii texturâ mollicellâ exorientes. 
Prute CIIIT
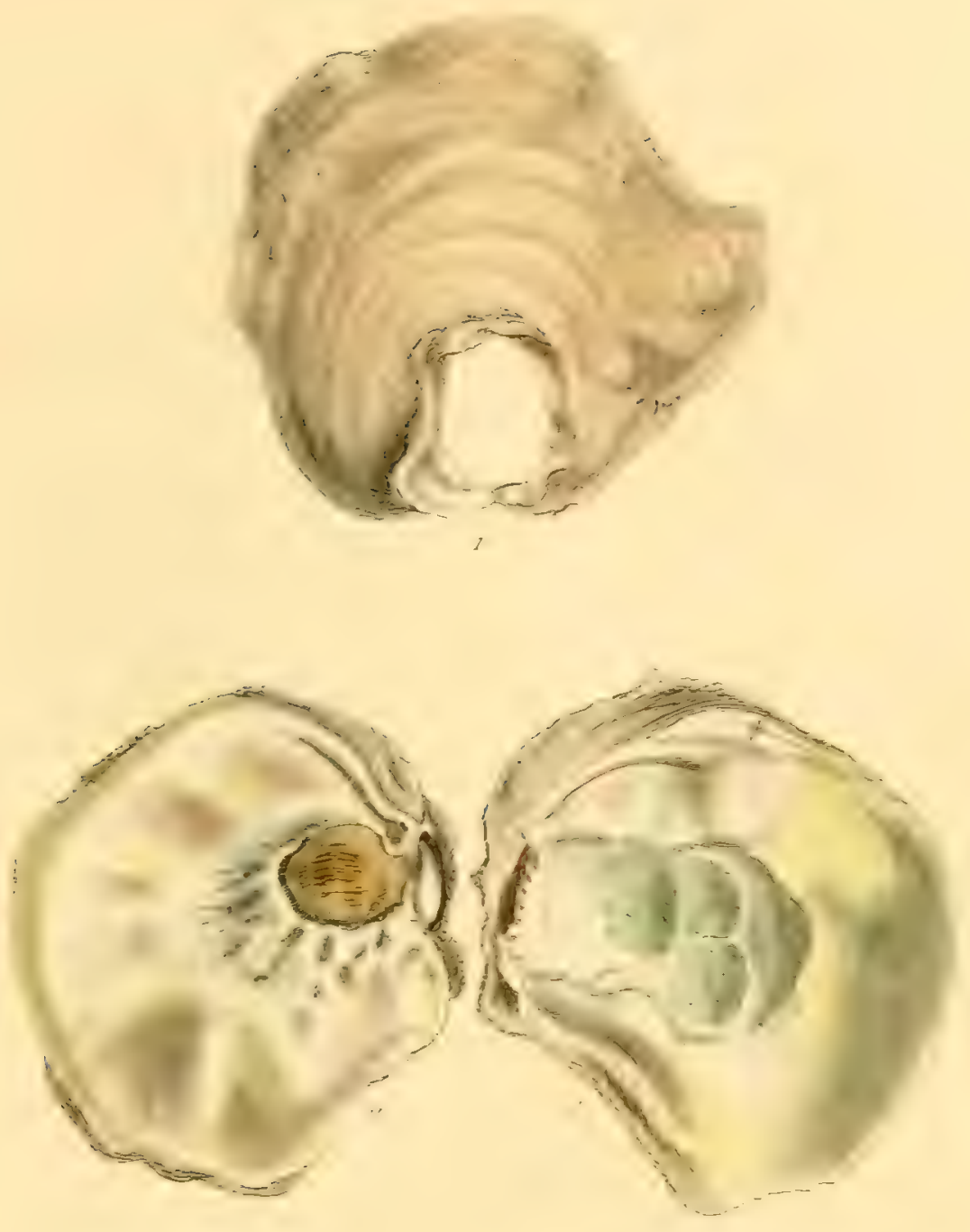

Anomera Ephipitiun. 

Testa semper bivalvis, ligamento cardinali nullo, musculis internis validè adhærens; vel statim vel pediculo aut tendine fibroso affixa.

The animals which we are now to consider differ materially in their system of organization from those of the preceding class. They have received the above title on account of their being provided with two long spirally-twisted brachia or arms, and are distinguished by other not less important particulars. The soft parts are differently arranged within the shell, the valves are not united by any ligament, and there is a marked change in the arrangement of their breathing apparatus. Although Pallas has given a short anatomical description of the Terebrutulc, it was not until the appearance of Cuvier's memoir on the anatomy of the Lingula that the true characters of these remarkable animals became known; it was then determined that the Brachiopoda should be set apart in a separate and distinct class. The anatomy of the Terebrutule and Orbicule has since been most elaborately set forth by Professor Owen in the 'Transactions of the Zoological Society,' and agrees in all its essential particulars with that of the Lingula previously described by Cuvier; subject, however, to certain modifications arising from the different situations they inhabit. The Lingule, which are provided with a long pedicle, commonly live near the surface, and are found at low water partially, if not entirely, buried in the sand for the protection of their fragile shells against the violence of the tides; the Terebratule, on the contrary, are found in deep water, attached in clusters to fragments of rocks and corallines by a bunch of short fibrous tendons issuing through an orifice in the shell.

The essential points in which these animals differ from other bivalve mollusks are as follows: First, in the position of the soft parts within the shell: in the Tropiopoda the back is placed against the hinge, and the sides against each valve; whilst in the Brachiopoda, the dorsal part of the visceral mass is against one valve, and the ventral part against the other. Secondly, in being provided with a pair of retractile brachia or arms : for in the place usually occupied by the branchie are two long spirally-twisted arms, generally more or less fringed, and so strongly resem- 
bling the branchix of the preceding class in some species, that they were at one time thought to be the true organs of respiration. These retractile arms are said to be in constant activity for the purpose of producing an inward current of water for the capture of animalculx and other alimentary prey. Thirdly, in the arrangement and position of the branchix: instead of the organs of respiration being distinctly formed in lateral lamellix upon the body as in many of the Tropiopoda, they consist of a number of beautiful veins and arteries incorporated within the substance of the two lobes of the mantle. The calcifying organ of the Brachiopoda, therefore, has a double function: in addition to its usual property of secreting the calcarcous mucus for the formation of the shell, it is made subservient to the circulation of the aërated fluid. Professor Owen observes, "That in this profuse distribution of vessels over a plain membranaceous surface, me perceive the simplest construction of the water-breathing organ, presenting a beautiful analogy with the elementary forms of the air-breathing organ in the Pulmoniferous Gasteropoda (Helices, Bulimi, e. g.*). The muscular system in these animals appears to be most complex; the Lingulce and Orbiculce are provided with three pairs of muscles, and the Terebratulc have four. The large muscles are destined to open and close the valves in the absence of a hinge ligament, and the small ones assist in sliding one valve over the other for the admission of water.

With regard to the situation that the Brachiopodous Mollusca should occupy in the natural system, as well as the rank to which they are entitled in the classification, authors have been much divided. By Dumeril and De Roissy they were associated in a particular class with the Lepudes, on account of a fancied resemblance in their spirally twisted

* In consequence of this new and peculiar arrangement of the respiratory system, the title of Brachiopoda has been changed by De Blainville to that of Palliobranchiata or mantle-breathing mollusks. It,is, perhaps, the more appropriate; but we have been guided in our selection of the former from a desire of basing the primary distribution of the Mollusca upon the organ of movement throughout (poda, a rovs pes); and in substituting the term Tropiopoda for that of Conchifera, in reference to the preceding class, we have selected the particular form of the foot as best calculated to secure a precision of rank in the nomenclature. 
arms to the cirrous tentacula of those animals; they differ, however, in not being articulated, and their relation altogether with the Lepades is one of very remote analogy. Cuvier distinguished them as a new and separate class, but still arranged next in order to the Lepades. Lamarck places them at the end of his "Conchifères Mononyaires," merely as a family of that order. Professor Owen and Deshayes both consider that they are entitled to take the rank of an order; the latter author moreover admits that there is far less affinity between the Brachiopoda and the rest of the acephalous mollusks than there is between the ackinowledged divisions of Bimuscular and Unimuscular. In accordance with our own candid opinion, and at the suggestion of Deshayes, we have adopted the still higher rank assigned to them by Cuvier, and we follow Lamarck in placing them after the Tropiopoda, upon the presumption that their branchial apparatus presents a modification of structure intermediate between that of the proximate classes.

The animal may be described as being of an ovate or oblong form, always contained within a bivalve shell; it is furnished with two long spirally-twisted ciliated arms, as also several muscles, and the mouth is central, but there is no head, or eyes. The abdominal viscera are small, protected on each side by the lobes of the mantle. The branchix are rascular and symmetrical, springing up within the soft texture of the mantle.

The shell is either horny or calcareous, and always bivalve; it has no hinge ligament, but adheres strongly to the animal by attachment of the muscles; it is also fixed externally either by a long pedicle or short fibrous tendon, or immediately by the lower valve.

The Brachiopoda, which are not very numerous, are divided into two families according to their mode of attachment; we propose to call them as follows :

\section{Tendinosa.}

Adherentia.

VOL. I. 


\section{Family 1. TENDINOSA.}

Testa vel tendine breviusculo, fibroso, vel pediculo plus minusve elongato, pendentè affixa.

The tendinous Brachiopoda are divided from the sessile in the same manner as the Lepades; the pedicle of the former, however, differs from that of the latter tribe of animals both in its situation and use. Instead of being a firm support to the shell, as in most of the Lepades, or used for the injection of the eggs, it serves merely as a pendant, giving to the animal but a limited sphere of motion. Many of them, however, are attached by a number of short fibres passing out through an orifice in the under valve. They are divided accordingly into two genera; in the former the shell is equivalve, in the latter it is inequivalve.

LiNGULA.

Terebratula.

LINGULA, Bruguière.

Testa tenuis vel cornea vel calcarea, viridis, interdum rubicundula, æquivalvis, equilateralis, pediculo affixa; apice subrostrato, sapissimè pervio, basi subacutâ interdum hiante. Impressiones musculares in utrâque valvâ duæ proximè imbutæ. Cardo nullus.

Until within the last fer years only one species of Lingula was known; and previous to the publication of Cuvier's anatomical investigation of the animal its sheli gave rise to much speculation amongst naturalists. 
Seba took it to be a pedunculate Lepas; and although he figured it with the pedicle, Linnæus, upon the discovery of an odd valve exhibiting no trace of any hinge ligament, described it as a Patella. Both Rumphius and Favanne considered it to be the calcareous shield of a Limux or land slug. Chemnitz, upon finding that the shell of Lingula was really bivalve, placed it with the Pinne ; and Dillwyn, in imitation of Solander, included it with the Mytili. Bruguière was the first to distinguish it by its present title in the plates of the 'Encyclopédie Méthodique,' in which he has been followed by Lamarck, Cuvier, and succeeding writers.

We place the Lingulx at the commencement of the class, because they hare the nearest affinity with the Tropiopoda; their body is proportionably larger than that of the rest of the Brachiopoda ; and although the branchix are incorporated within the substance of the mantle, they nevertheless present some indication of the lamellar structure of the preceding class. Lanarck placed them at the end of his family of Les Brachiopodes, because in referring the Cranice to his fossil family of Les Rudistes, he found it necessary to follow up their affinity with the Orbicula.

The shell of Lingula may be described as being thin, either horny or calcareous, and of a green or somewhat ruddy colour; it is equivalve, equilateral, and adheres to marine substances by a long pedicle; it is somewhat beaked at the apex, and generally open, and at the base it is rather acute, sometimes gaping. There are tro muscular impressions approximating near the centre in each valve; and the valves are destitute of any hinge, being supported only by their separate muscular adhesion.

Mr. Cuming informs us, that he net with a considerable number of Lingule anatine during his cruise amongst the Philippine Islands; they are often eaten by the natives, but he does not consider them a wholesome article of food. He attributes the long scarcity of this animal to the fact of their having escaped the notice of travellers from their peculiar mode of habitation. They live buried in hard sand, and may only be dug out at low water. 
Examples.

Pl. CXXV. Fig. 1.

Lingula Audebardir, Broderip, Transactions Zool. Soc., vol. i. pl. 23. f. 14. Deshayes, new edit. of Lamarck, vol. vii. p. 390.

PI. CXXV. Fig. 2.

Lingula semen, Broderip, Transactions Zool. Soc, vol. i. pl. 23. f. 17. Deshayes, new edit. of Lamarck, vol. vii. p. 391

Pl. CXXV. Fig. 3.

Lingula anatina, Lamarck, Anim. sans vert., new edit, vol. vii. p. 390. Enc. Méth., pl. 250. f. 1, $a, b, c$. De Blainville, Manuel de Malacologie, pl. 52, f. 3.

Pinna unguis, Chemnitz.

Mytilus lingua, Solander.

(An odd valve' Patella unguis, Linnæus.

PI. CXXV. Fig. 4.

Lingula tumidula, Nobis, Proceedings Zool. Soc., 1841.

TEREBRATULA, Bruguière.

Testa inxuuivalvis, aquilateralis, ovalis vel orbiculata, tendine fibrogelatino, breviusculo, affixa. Valva superior apice producto, sæpè incurvo, semper pro transitu tendinis perforato, cum processu dentiformi cardinali ad utrumque latus. Valva inferior processibus duobus testaceis gracilibus, plerumque furcatis, variè tlexuosis, in corpus animalis redegentibus. Impressiones musculares plurimx indistinctè imbutre. 
LINGULA.

Plate CXXV.
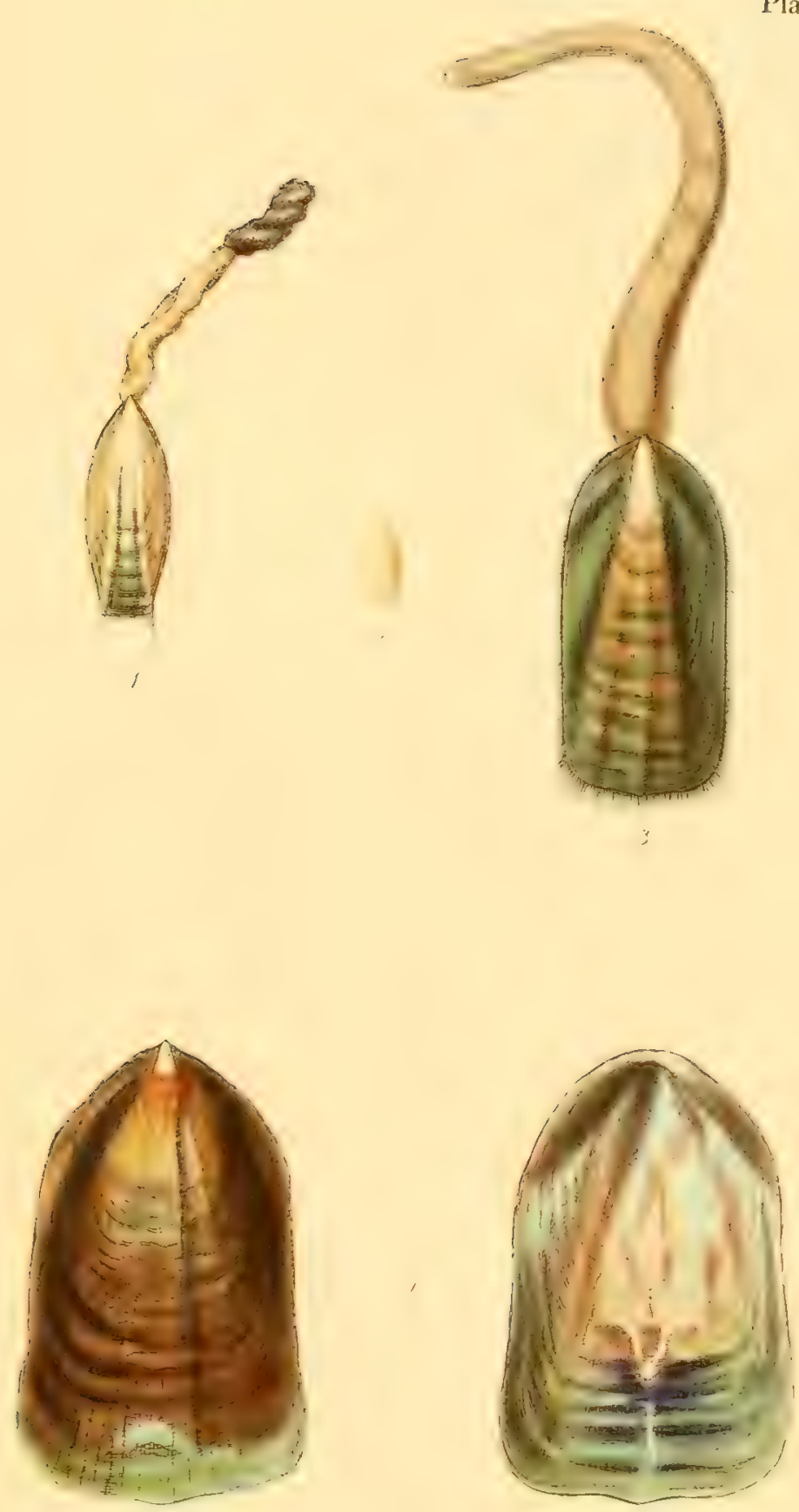


Plate CXXTI.
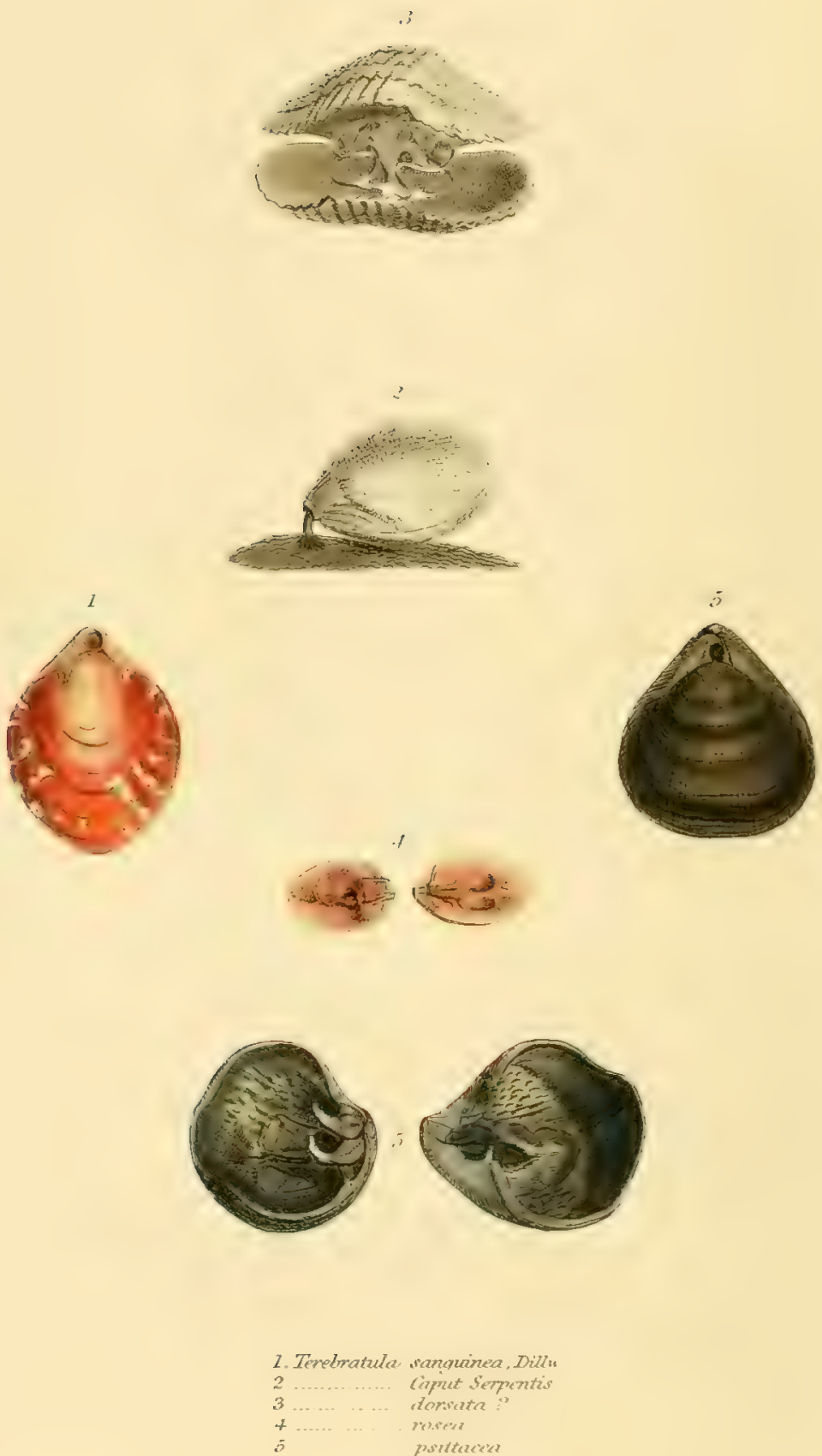
This genus may also be said to have been introduced by Bruguière in the plates of the 'Encyclopédie Méthodique,' and from the extent of its geological relations it has always been one of considerable interest; it is, in fact, richer in fossil species than any other. 'The Terebratulie were associated by Linnæus and his followers with the Anomice on account of the resemblance of their mode of attachment, namely, by means of a muscular tendon passing through an orifice in the shell; in this genus, howerer, it is the upper valve that is perforated, and there is no calcareous deposit at the extremity of the tendon as in Anomia; the fibrous composition of it, indeed, rather suggests a modification of the byssus of the Ariculucen. The Terebratulæ have a shell of very different construction from that of the Lingule ; instead of the valves being equal and held together by muscular attachment only, there is a considerable inequality in them; each valve is provided with one or more dentiform processes, by means of which they interlock so closely with each other as seldom to he separated without breaking. In some speries these processes are much less fully developed, and the lower or imperforate valve is furnished with a curious testaceous apparatus in the shape of a flattened hoop; this internal skeleton, if it may be so called, is somewhat elastic, and is destiner to give attachment to the muscular stem of the brachia or arms.

The shell of Terebratula may be described as being inequivalve, inequilateral, oval or orbicular, adhering by a rather short fibro-gelatinous tendon. The upper valve is always produced at the apex, often curved inwards, and perforated for the passage of the tendon; it has also a single dentiform hinge process on each side. The lower valve is furnished with two slender shelly processes, generally recurved and variously bent, anastomosing within the body of the animal. There are several muscular impressions, but they are very indistinctly marked

\section{Examples.}

\section{PI. CXXVI. Fig. 1.}

Terebratula sanguinea, Sowerby, Genera of Shells, No. 15. Anomia sanguinea, Dillwyn. 
Pl. CXXVI. Fig. 2.

Terebratula caput-serpentis, Lamarck, Anim. sans vert., new edit., vol. vii. p. 332. Enc. Méth., pl. 246. f. 7. $a$ to $f$. Anomia caput-serpentis, Linnæus.

\section{Pl. CXXVI. Fig. 3.}

Terebratula dorsata, Lamarck, Anim. sans vert., new edit., vol. vii. p. 331. Enc. Méth., pl. 242. f. 4. $a, b, c$. Anomia dorsata, Gmelin.

Pl. CXXVI. Fig. 4.

Terebratula rosea, Sowerby, Genera of Shells, No. 15.

\section{Pl. CXXVI. Fig. 5.}

'Terebratula psittacea, Lamarck, Anim. sans vert., new edit, vol. vii. p. 333. Enc. Méth., pl. 244. f. 3. a, b. Anomia psittacea, Gmelin.

\section{Family 2. ADHERENTIA.}

Testa statim affixa, valvá inferiore pro transitu tendinis plerumque fissuratâ.

In this family the shell adheres immediately; there is still, however, a muscular tendon in most of them passing through a perforation or fissure in the lower valve. The valves are not united by any ligament, nor do they exhibit, except in the genus Thecidium, the cardinal processes or internal skeleton so characteristic of the Terebratula. Their shell is for the most part rather thin, and in composition may be said to be rather horny than shelly.

The Brachiopoda Adhærentia are divided into three genera, as follows :

Thecidium.

Orbicula.

Crania. 
CLASS II. BRACHIOPODA. FAMILY 2. ADH ERENTIA. 183

\section{THECIDIUM, Defrance.}

Testa ovata, parva, inæquivalvis, subrequilateralis, terebratuliformss, imperforata, valvâ concavâ affixa. Valva inferior processibus duobus cardinalibus, internis brevibus; areâ irregulariter subtrigonà ad umbonem acutiusculum extensà Valva superior planiuscula, basi externè appendiculá brevi obtusâ; internè processibus duobus lateralibus cardinalibus, ligamento nullo.

The Thecidia were separated from the Terebratule by Defrance, and appear to have escaped the particular notice of Lamarck; they may, however, be reckoned of much importance in the classification on account of their shells being exactly intermediate between those of the two fanilies of the Brachiopoda. They resemble the Terebratulce not only in shape, but in having the cardinal processes, whilst they differ in being imperforate, and therefore destitute of any pedicle or tendon. This genus is also one of considerable interest to the geologist; in fact, at the time of its first introduction by Defrance it was known only in the fossil state.

The shell of Thecidium may be described as being ovate, small, inequivalve, nearly equilateral, imperforate, and attached by the concave valve, which is furnished with two short cardinal processes, and a rather irregularly-triangular area extending to the point of the umbo. The upper valve is flattish, and has a small, short, obtuse appendage at the base; it is also provided with two lateral cardinal processes, closely interlocking with those of the lower valve; the hinge, however, as in all the Brachiopoda, is entirely destitute of any ligament.

The interior of the shell of Thecidium presents a new and very singular appearance, which we have not noted in our generic description; the internal configuration of the upper valve is peculiar to this genus of Brachiopoda, and appears to depend upon some peculiarity unknown to us 
in the organization of its inhabitant. The inside of both valves is of a very pale greenish colour, and finely granulated; the lower valve is convex, but the upper one is flat and curiously indented, as if to fit certain corresponting parts in the body of the animal. These indentations, which spread round in semicircular direction from the hinge, look exactly as if they were picked out in wax; and in a specimen which we have examined with considerable minuteness, they were filled with the dried remains of mumerous fine cilia. As the only recent species known is found in the iledirerranean, we hope that Professor Owen, or some other learned anatomist, will be able to account for this singular development.

\section{Examples.}

Pl. CXXVII. Fig. 1 and 2. (fossil.)

Thecidium pumilum, Sowerby, Genera of Shells, No. 20. Deshayes, Note in new edit. of Lamarck, vol. vii. p. 348.

\section{Pl. CXXVII. Fig. 3. (fossil.)}

Thecinium digitatum, Sowerby, Genera of Shells, No. 20. Deshayes,

Note in new edit. of Lamarck, vol. vii. p. 348.

Thecidea hieroglyphica? Defrance.

Pl. CXXVII. Fig. 4 and 5. (fossil.)

Thecidium recurvirostre, Sowerby, Genera of Shells, No. 20. Deshayes, Note in new edit. of Lamarck, vol. vii. p. 349. Thecidea curvirostris, Defrance.

Pl. CXXVII. Fig. 6 and 7.

'T'uecidium Mediterraneum, Defrance, Dict. Sci. Nat., vol. liii. p. 434. Sowerby, Genera of Shells, No. 20. Risso, Prod. de la mer de Nice, t. 4. f. 183. 
Plate CXITIII.

(6)

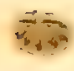

3

(4)

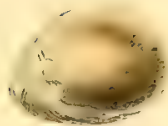

(8,

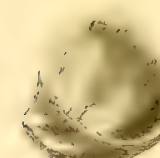

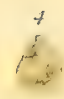

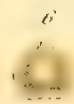

I. 2. Theridian mencitom

3. ............... digutation.

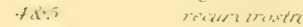



CRANIA, Bruguière.

Testa compressa, subquadrata, inæequivalvis, ææquilateralis ; valvis, superiore convexâ, patelliformi, inferiore planulatì, subtùs aftixía, facie internâ impressionibus muscularibus quatuor distinctis profundè imbutâ, quarum duæe subcentrales approximatæe. Cardo nullus.

The Anomia craniolaris of Linnxus was selected by Bruguière for the formation of the present genus: although unacquainted with the animal inhabitant, he did not fail to recognise a resemblance in its shell to that of the Brachiopoda, for in the 'Encyclopédie Méthodique' he figures it in the exact situation which it is now destined to occupy. The animal of Crania has, however, been both described and figured by Poli under the title of Criopus; and the fact of its having been confounded by Lamarck with that of Orbicula, accounts for some hesitation on the part of the lastnamed author in not including the present genus in his family of 'Les Brachiopodes,' "mais l'animal étant inconnu, nous ne pouvons savoir si c'est un Brachiopode." It is certainly much to be regretted that Professor Owen did not succeed in obtaining the soft parts of Crania, when engaged with the dissection of Terebratula and Orbicula; Sowerby, however, has given his testimony of the presence of the spiral arms, and there is therefore little doubt of the accuracy of the situation to which this genus is now assigned. Few authors have acknowledged more than one recent species; but M. Honinghaus of Crefeld, who has given much attention to the identification of the Cranixe, asserts that two or three different species have been referred to the Crania personata.

The shell of Crania is described as being compressed, somewhat square. inequivalve, and equilateral; the upper valve is convex and patelliform, the lower flat and attached. The interior of the latter exhibits four very distinct muscular impressions, two of which are subcentral and approximate. There are no cardinal processes, nor any indication of a hinge.

VOL. I. 
Examples.

Pl. CXXVIII. Fig. 1 and 2.

Crania personata*, Lamarck, Anim. sans vert., new edit, vol. vii. p. 298. Enc. Méth., pl. 171. f. 1, 2. Sowerby, Trans. Linn. Soc., vol. xiii. pl. 26. f. 3.

Anomia craniolaris, Linnæus.

(An odd valve) Patella distorta, Montague.

Pl. CXXVIII. Fig. 3. (fossil.)

Crania Parisiensis, Defrance, Dict. Sci. Nat. Sowerby, Min. Conch., pl. 408. Honinghaus, Monog. of Crania, f. 8.

PI. CXXVIII. Fig. 4 and 5. (fossil.)

Crania nummulus, Lamarck, Anim. sans vert., new edit, vol. rii. p. 300. Honinghaus, Monog. of Crania, f. 5.

PI. CXXVIII. Fig. 6. (fossil.)

Crania costata, Sowerby, Genera of Shells, No. 12 . Honinghaus, Monog. of Crania, f. 11 .

Pl. CXXVIII. Fig. 7. (fossil.)

Crania antiqua, Defrance, Dict. Sci. Nat., pl. 80. f. 1. De Blainville, Manuel de Malacologie, pl. 59. f. 1. Honinghaus, Monog. of Crania, f. 6 .

\section{ORBICULA, Lamarck.}

Testa cornea, orbicularis, subirregularis, inæequivalvis, subcompressa ; valvis, superiore patelliformi, inferiore planulatâ, fissurâ subcentrali

* 'The species which is here figured from Sowerby's 'Genera of Shells,' has been namerl Crania rostrata by $\mathrm{M}$. Hœninghaus, upon the opinion that it is not the true Crania personata of lamarck, a question which we only regret that it is not in our power to decide. 
Plate CXITIII.
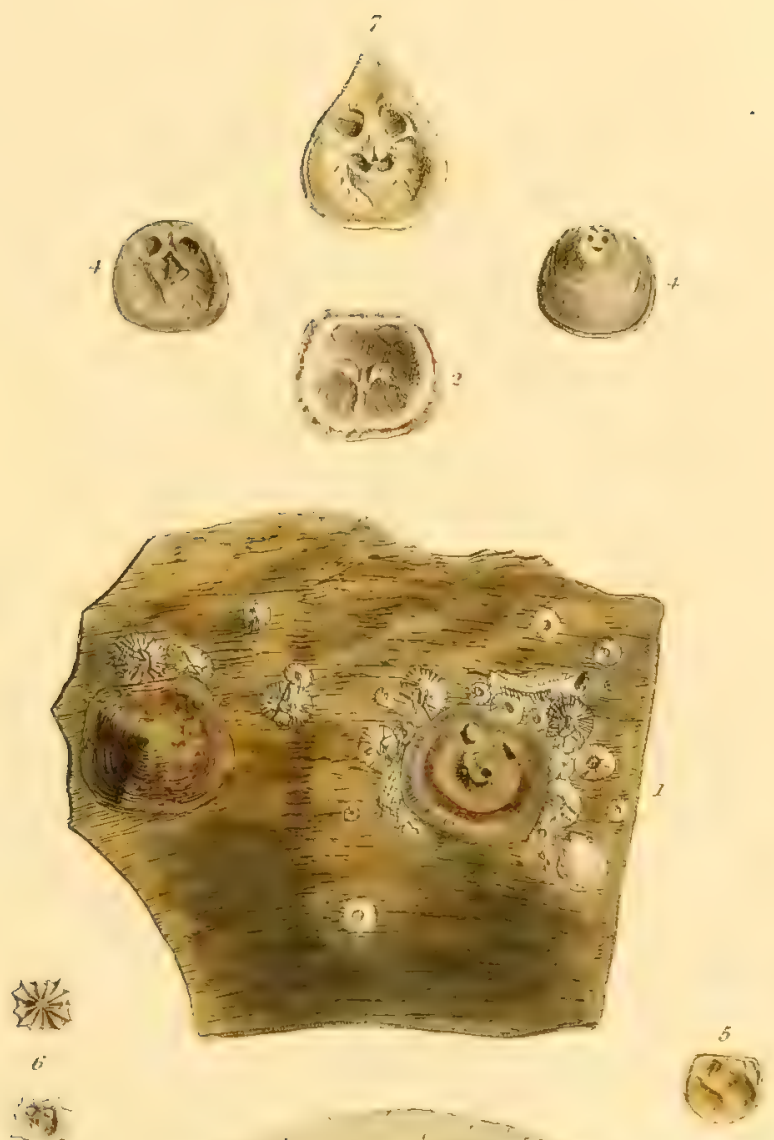

id

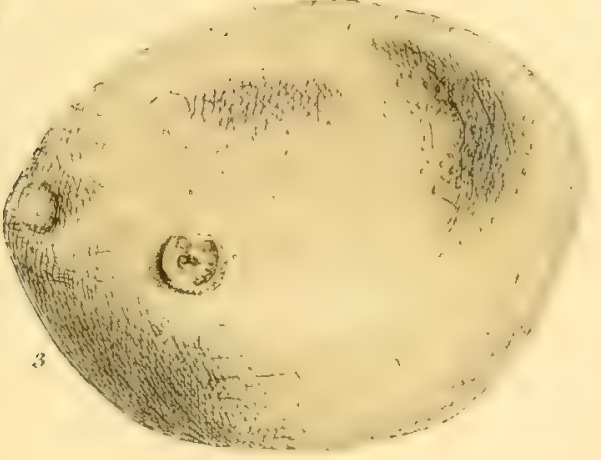

Is.2. Cominia personata.

3.......... Pmiviensis :

B..... erwiate. 

pro transitu tendinis adhasionis, laminâ longitudinali obtusiusculì intùs terminatâ. Impressiones musculares in utrâque valvâ quatuor, quarum duxe majuscula, subcentrales, approximatie, dux minores, posticæ, submarginales, distantes. Cardo nullus.

The present genus was instituted by Lamarck for the purpose of distinguishing a true Brachiopodous mollusk unknown to early writers; the upper valve of its shell had been described by Müller and Gmelin as a Patella, an error, however, which cannot be wondered at, when it is known that in this class of Mollusca the valves are not united by any hinge ligament. The Orbicula are peculiar in the composition of their shells, which are much more horny than calcareous; and they differ also in their mode of attachment. Although fixed immediately to marine substances one upon the other, they do not adhere by any part of the shell, but by means of a cartilaginous tendon passing through a longitudinal fissure in the lower valve. 'This fissure is situated in the centre of a small oval depression, and the organ of adhesion, after passing through it, immediately expands, so that the edges of the slit become concealed.

Another genus, Discina, was at one time proposed by Lamarck; but upon the publication of Sowerby's Memoir on the Brachiopoda in the 'Transactions of the Linnean Society,' it was abandoned. In this paper Mr. Sowerby successfully shows that the Discine are nothing more than young Orbicula.

The shell of Orbicula may be described as being horny, orbicular, somewhat irregular, inxquivalve, and rather compressed; the upper valve is patelliform, the lower flat. In the centre of the latter is a small oval depression, with an oblique fissure running through it for the passage of the tendon of adhesion, and anterior to this is a flat, rather obtuse longitudinal plate projecting into the interior of the shell. There are four muscular impressions in each valve; two of them are rather large, approximating near the centre, and the smaller pair are posterior, submarginal, and rather distant. There is no hinge. 
188 CLASS I1. BRACHIOPODA. FAMILY 2. ADHERENTIA.

Examples.

PI. CXXIX. Fig. 1 and 2.

Orbicula Levis, Sowerby, Genera of Shells, No. 13. Deshayes, new edit. of Lamarck, vol. vii. p. 317.

PI. CXXIX. Fig. 3 to 5.

Orbicula Norvegica, Lamarck, Anim. sans vert, new edit., vol. vii. p. 316. Sowerby, Trans. Linn. Soc., vol, xiii. pl. 6. f. 2. De Blainville, Manuel de Malacologie, pl. 55. f. 5.

Anomia turbinata, Dillwyn

(An odd valve) Patella anomala, Müller. Gmelin. 
Tlute CXXIX.
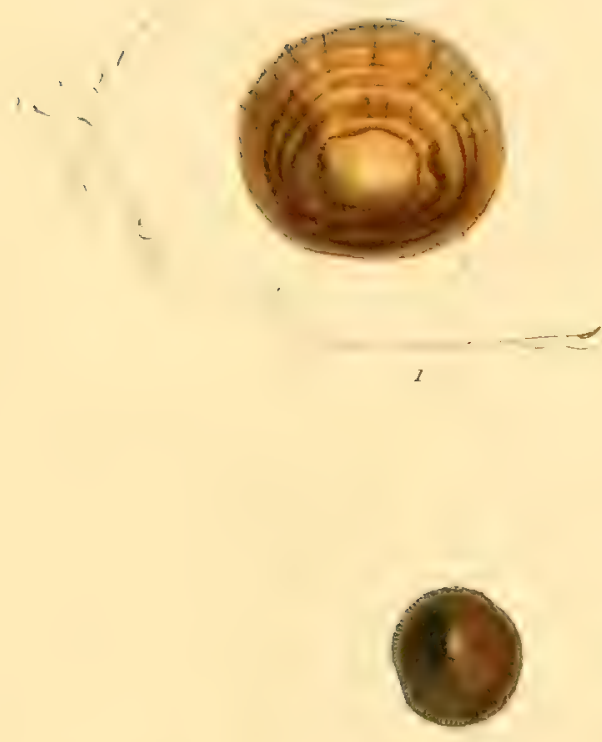

.,
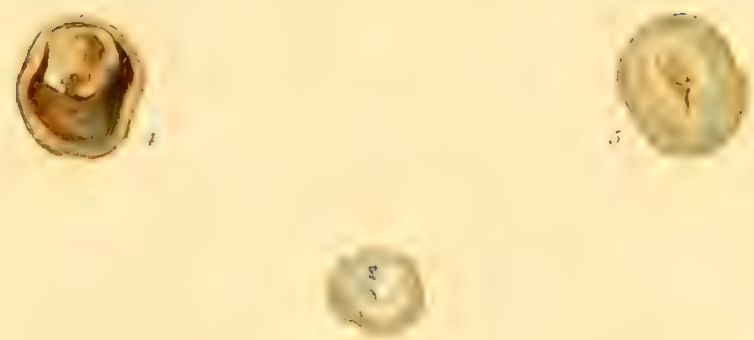

7.2. Brbicula learis.

3.t.5... Homeriea 



\section{NOMENCLATURA ALPHABETICA.}

A.

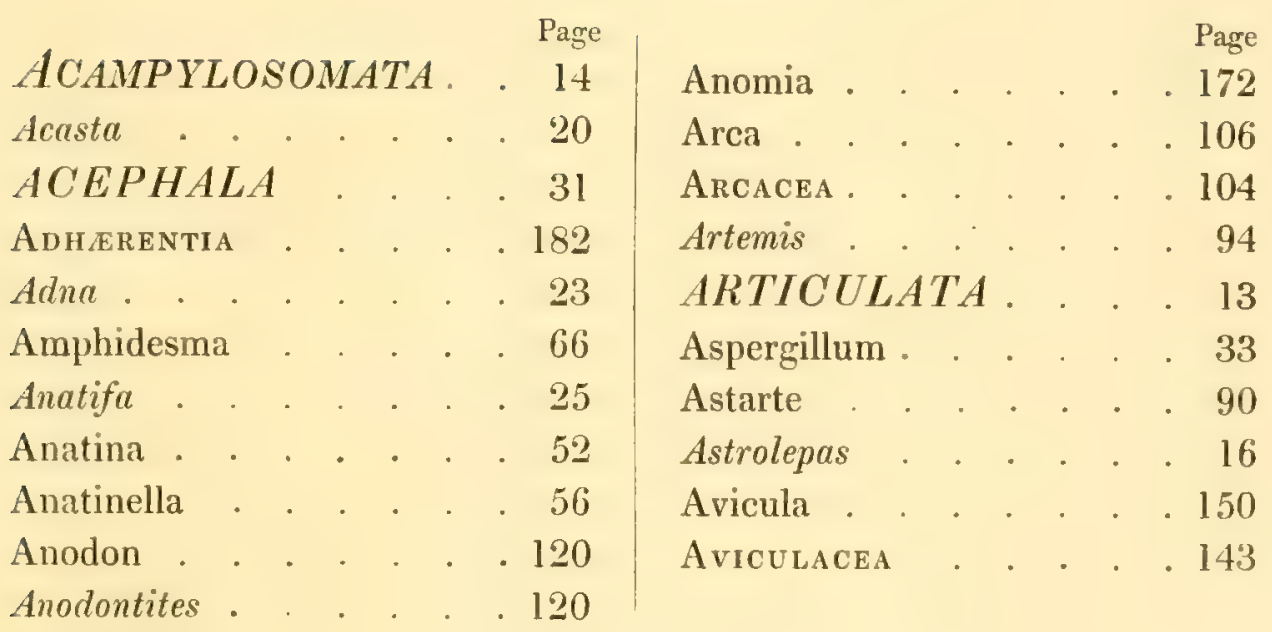

B.

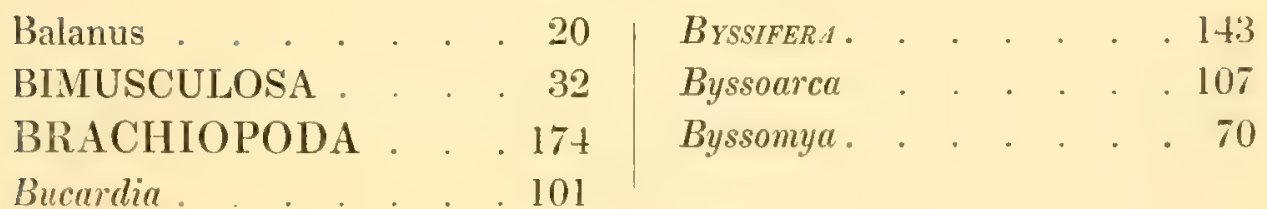


C.

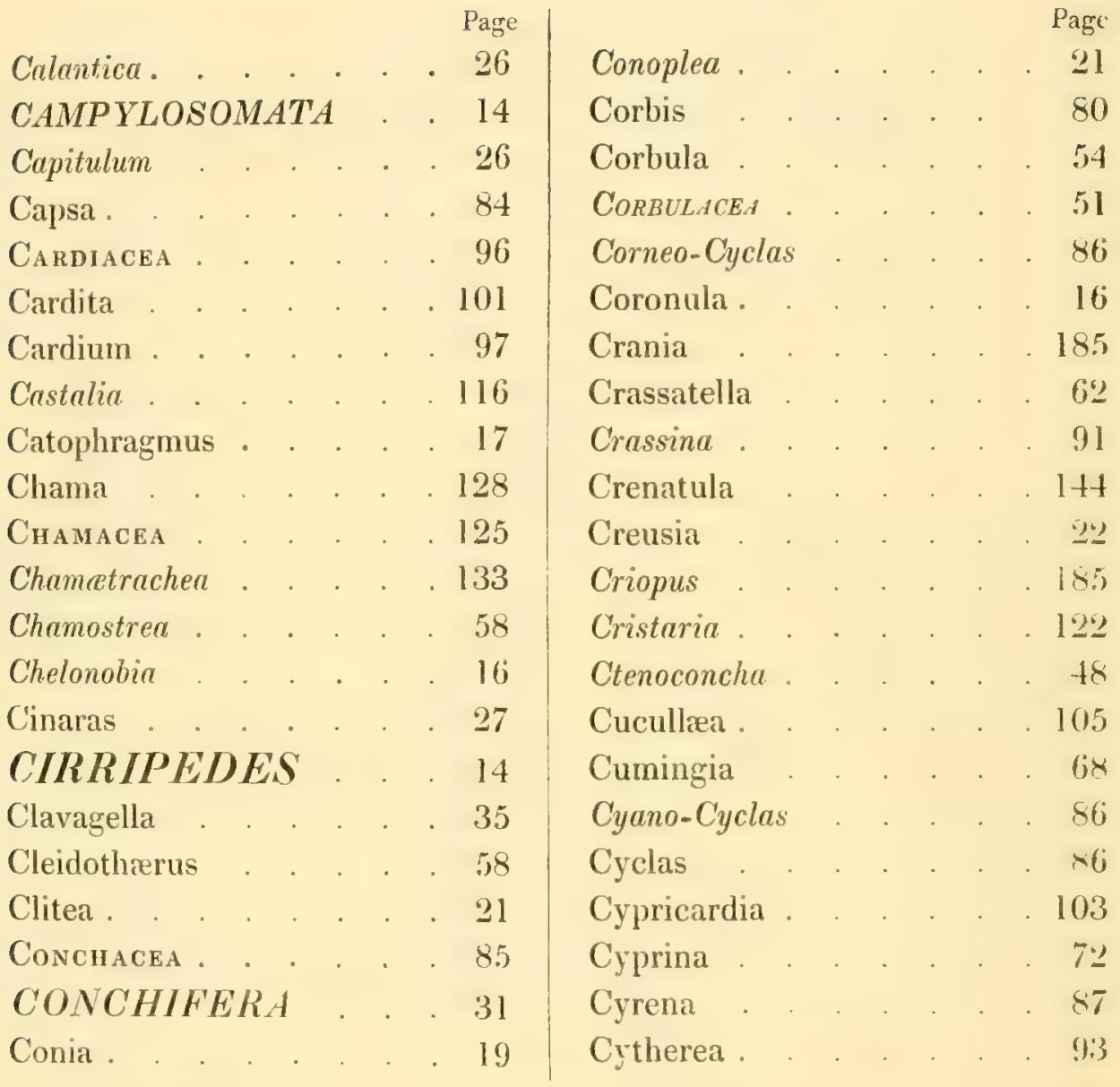

D.

Dipsas. . . . . . . . 122

Donax . . . . . . 82

Diptodon . . . . . 120

Dreissena . . . . . . 140

Discina 187 
E.

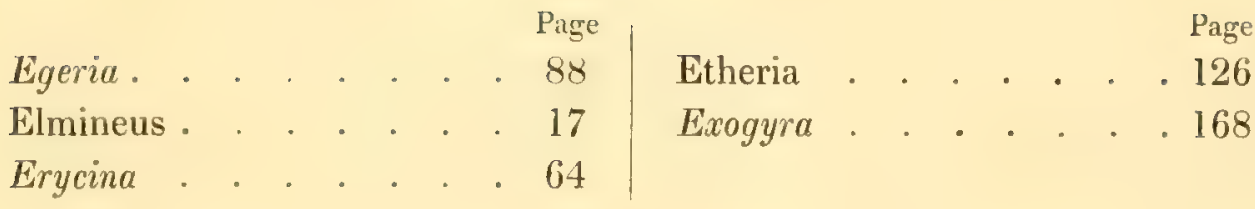

F.

Fistulana

G.

Galathæa . . . . . $87 \mid$ Glycimeris . . . . 46

Galeomma . . . . 78 Gnathodon . . . . 62

Gastrochæna. . . . . 36 Gryphæa . . . . . 167

Glaucoderme . . . . 156 Gymnolepas . . . . 28

Glauconome . . . . . 48

H.

Harpax . . . . . . . $162 \mid$ Hippopus. . . . . . 133

Hiatella . . . . . . 70 Hyria . . . . . 119

Hinnites . . . . . . 159 |

I.

INARTICULATA . . . 13 IRIDINIDE . . . . . 116

Iridina. . . . . $121 \mid$ Isocardia . . . . 100 
L.

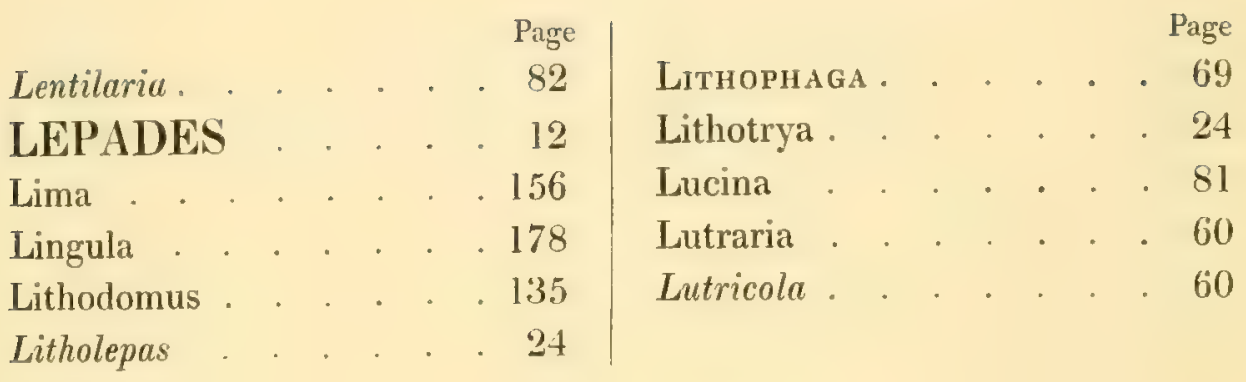

M.

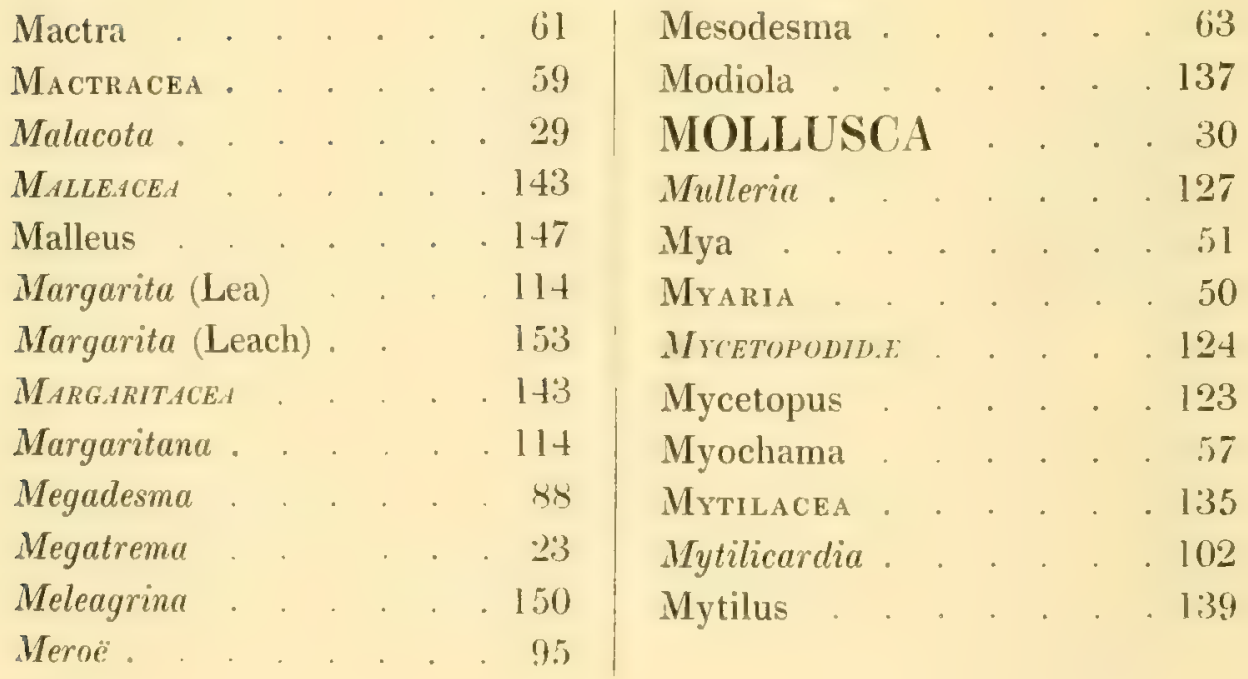

N.

Naiades . . . . 114

Nucula . . . . . . 108

Novaculina

Nymphacea . . . . . 74 
O.

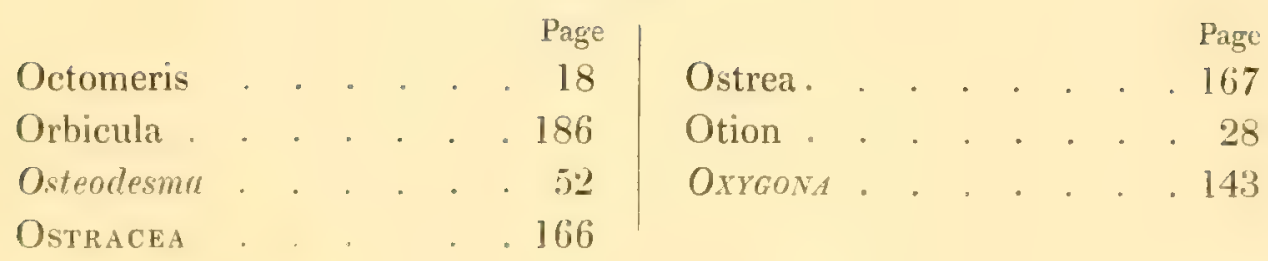

P.

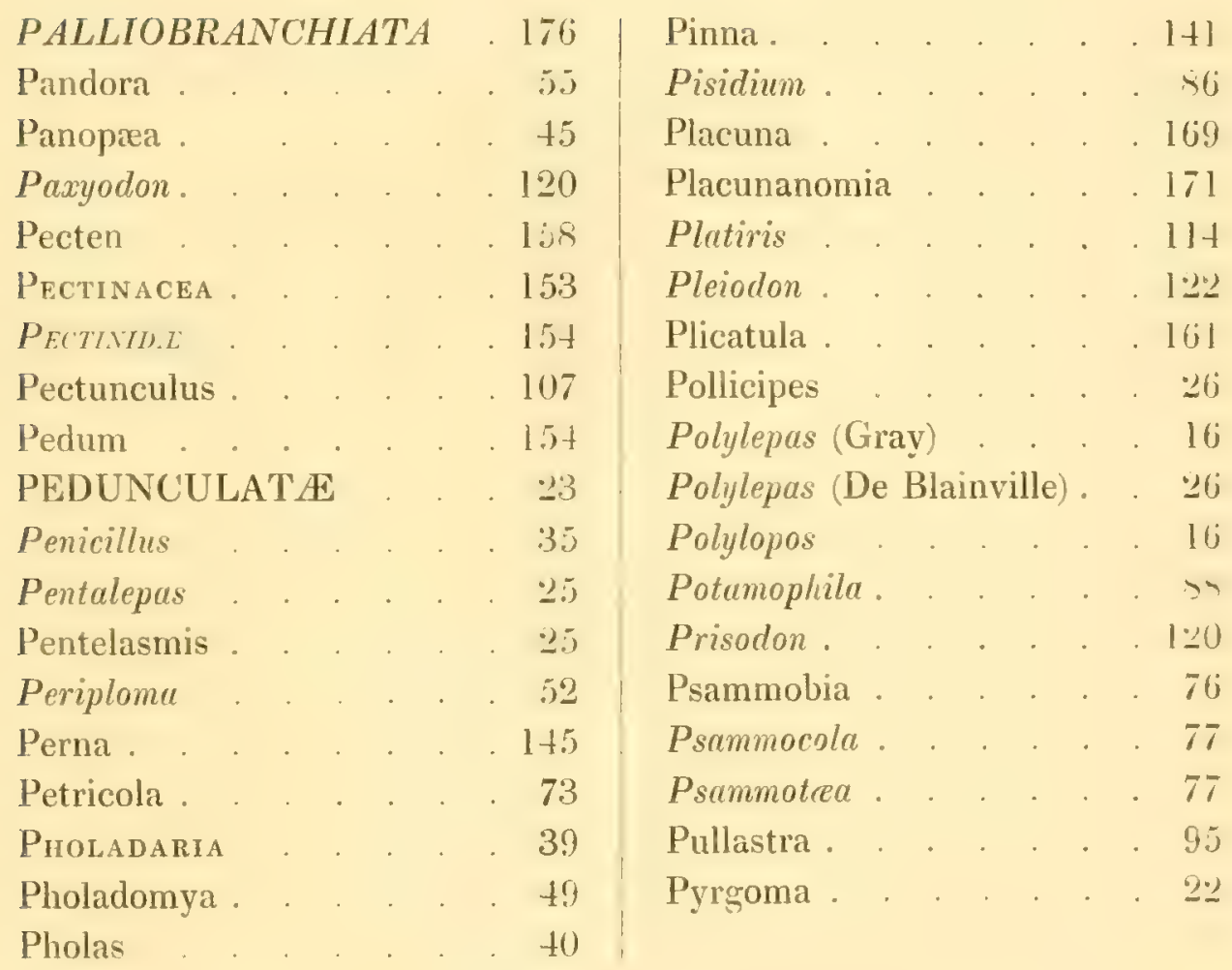


R.

S.

\begin{tabular}{|c|c|c|c|c|c|c|c|c|c|c|}
\hline & & & & Page & Solecurtus & & & & & \\
\hline Sanguinolaria & . & & . & . 75 & Solemya . & & & & & \\
\hline avignium & - & & & 23 & Solen & & & & & \\
\hline axicava . & . & • & . & 70 & Solenacea & & & & & \\
\hline calpellum & . & - & . & 25 & Solenella . & & & & & \\
\hline chizodesma. & . & & & 61 & Soletellina & & & & & \\
\hline Senoclita. . & . & & & 28 & Spatha. & & & & & \\
\hline Septaria. & & . & & 38 & SPONDYLIDA & & . & & & \\
\hline erpula. & & & & 35 & Spondylus & & . & & . & \\
\hline ERPULACEA & . & & & 34 & SUBOSTRACEA & & . & & & \\
\hline ESSILES & & & & . 15 & Symphynota & & & & & \\
\hline nilium & & & & . 26 & & & & & & \\
\hline
\end{tabular}

T.

Tellina . . . . . 79

Tellinides. . . . . 79

Tendinosa . . . . 178

Terebratula .... 180

Teredo . . . . 37

Thecidium . . . 183

Thracia . . . . 53

Tridacna . . . . . 132
Tridacnacea . . . . 131

Trigonacea. . . . . 112

Trigonia . . . . . 112

Triptodon. . . . . 120

TROPIOPODA . . . 30

Tubicinella . . . 15

Tubicola $\ldots . .33$ 
U.

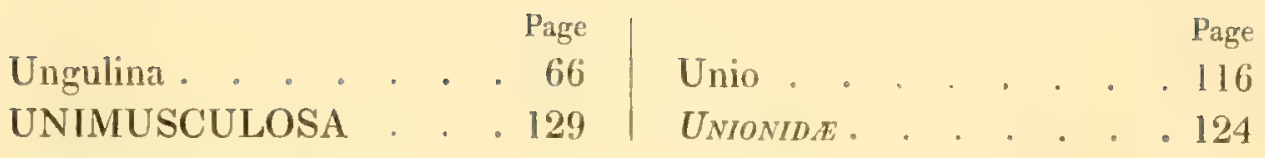

$V_{s}$

\begin{tabular}{l|l|l} 
Venericardia . . . . 102 & Verruca . . . . . . . 22
\end{tabular}

Venerupis. . . . . 70 Vulsella . . . . . 148

Venus . . . . . 91 91

X.

Xylophaga . . . . 39 | Xylotrya . . . 40

END OF TIE FIRST VOLUME. 





